UNIVERSIDADE FEDERAL DO AMAZONAS

FACULDADE DE CIÊNCIAS AGRÁRIAS

PROGRAMA DE PÓS-GRADUAÇÃO EM CIÊNCIAS PESQUEIRAS NOS TRÓPICOS

ROBSON OLIVEIRA DE SOUZA

CAPACIDADE DE CARGA DE PESCA ESPORTIVA NO RIO ÁGUA BOA DO UNIVINI, NA REGIÃO DO BAIXO RIO BRANCO - RORAIMA BRASIL. 
ROBSON OLIVEIRA DE SOUZA

CAPACIDADE DE CARGA DE PESCA ESPORTIVA NO RIO ÁGUA
BOA DO UNIVINI NA REGIÃO DO BAIXO RIO BRANCO - RORAIMA
- BRASIL

Tese apresentada ao Programa de PósGraduação em Ciências Pesqueiras nos Trópicos da Universidade Federal do Amazonas, como requisito parcial para a obtenção do título de Doutor em Ciências Pesqueiras nos Trópicos, área de concentração Uso Sustentável de Recursos Pesqueiros Tropicais.

Orientador: Prof. Dr. Carlos Edwar de Carvalho Freitas

Co-orientadora: Prof ${ }^{a}$. Dr ${ }^{a}$. Flávia Kelly Siqueira de Souza 


\section{Copyright @ 2019 by Robson Oliveira de Souza}

Todos os direitos reservados. Está autorizada a reprodução total ou parcial deste trabalho, desde que seja informada a fonte.

Universidade Federal do Amazonas - UFAM

Programa de Pós-Graduação em Ciências Pesqueiras nos Trópicos

CAPES

Universidade Estadual de Roraima - UERR

Dados Internacionais de Catalogação na Publicação (CIP)

S729c SOUZA, Robson Oliveira de.

Capacidade de carga de pesca esportiva no Rio Água Boa do Univini na região do Baixo Rio Branco - Roraima - Brasil. / Robson Oliveira de Souza. Manaus-AM: UFAM, 2019.

157 f. il. Color $30 \mathrm{~cm}$.

Tese apresentada ao Programa de Pós-Graduação em Ciências Pesqueiras nos Trópicos da Universidade Federal do Amazonas, como requisito parcial para a obtenção do título de Doutor em Ciências Pesqueiras nos Trópicos, tendo como área de concentração Uso Sustentável de Recursos Pesqueiros Tropicais, sob a orientação do Prof. Dr. Carlos Edwar de Carvalho Freitas e coorientação da Profa . Dra $^{a}$. Flávia Kelly Siqueira de Souza.

Inclui apêndices.

Inclui produto (cartilha informativa).

1. Sustentabilidade 2. Pesca esportiva 3. Capacidade de carga 4. Reposição dos estoques pesqueiros I. Freitas, Carlos Edwar de Carvalho (orient.) II. Souza, Flávia Kelly Siqueira de (coorient.) III. Título

UERR.Tese.Dout.Cie.Pes.2019.01

$$
\text { CDD - } 799.11 \text { (21. ed.) }
$$


ROBSON OLIVEIRA DE SOUZA

\title{
CAPACIDADE DE CARGA DE PESCA ESPORTIVA NO RIO ÁGUA BOA DO UNIVINI NA REGIÃO DO BAIXO RIO BRANCO - RORAIMA - BRASIL
}

\author{
Tese apresentada ao Programa de Pós-Graduação \\ em Ciências Pesqueiras nos Trópicos da \\ Universidade Federal do Amazonas, como \\ requisito para obtenção do título de Doutor em \\ Ciências Pesqueiras nos Trópicos, área de \\ concentração em Uso Sustentável de Recursos \\ Pesqueiros Tropicais.
}

Aprovada em 26 de Julho de 2019

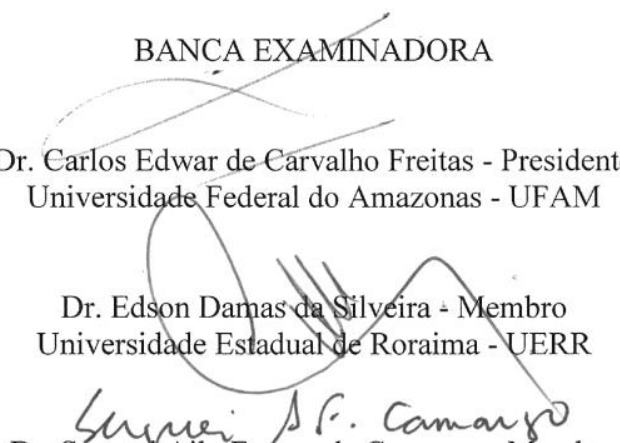

Dr. Sergue Aily Franco de Camargo - Membro

Universidade Estadual de Roraima - UERR

Mavia Anzilua de A. Corria

Dra. Maria Angélica de Almeida Corrêa - Membro

Universidade Federal do Amazonas - UFAM

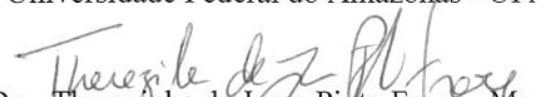

Dra. Therezinha de Jesus Pirto Fraxe - Membro

Universidade Federal do Amazonas - UFAM 


\section{Dedicatória}

\section{Ofereço:}

A meus pais, Sebastião França de Souza (in memoriam) e Coracy Oliveira de Souza.

À minha família, minha esposa Giselma Tonelli, meus filhos Gabriela, Luiza e Ulysses Pereira de Souza, e minha neta Claudia Medeiro

\section{Dedico:}

Aos proprietários de empresas de Turismo de Pesca Esportiva, pescadores esportivos, guias de pesca que atuam no Rio Água Boa do Univini. 


\section{Agradecimento}

A Deus, por me conceder saúde, sabedoria, força, coragem para lutar por meus sonhos e a realização desse sonho que ficou adormecido durante 19 anos até a sua conclusão.

Para ser um Doutor é necessário muito estudo e dedicação. São intensas horas de atividades dedicadas aos estudos. Este espaço destina-se a agradecer àqueles que incansavelmente me auxiliaram na realização dessa conquista.

Ao Professor Doutor Carlos Edwar de Carvalho Freitas, pela orientação, estímulo, crédito, amizade e esforço dispensado para transmitir seus conhecimentos ao longo destes anos, fazendo do trabalho um constante aprendizado durante e após a conclusão do Doutorado.

À minha Co-orientadora Professora Doutora Flávia Kelly Siqueira de Souza, pelo acolhimento no grupo do PIATAM, pelos ensinamentos constantes durante o período do curso, pela amizade e apoio que me proporcionou na conclusão do curso.

À Universidade Federal do Amazonas - UFAM, através dos professores e funcionários do Curso de Pós-Graduação em Ciências Pesqueiras nos Trópicos (PPG CIPET/UFAM), em especial, à Coordenadora do Curso - Professora Doutora Kedma Cristine Yamamoto, e à servidora Antônia da Costa Pereira.

Aos colegas e amigos do PPG-CIPET/UFAM, estes, responsáveis pelos importantes momentos de reflexão sobre os novos conhecimentos em Ciências Pesqueiras, apoio e amizade.

À Universidade Estadual de Roraima - UERR, por acreditar no potencial do seu servidor, permitindo-lhe o tempo de afastamento necessário para qualificação na busca da construção de um novo saber sobre a pesca esportiva no Rio Água Boa do Univini, no Estado de Roraima e na Amazônia Brasileira.

À Coordenação de Aperfeiçoamento de Pessoal de Nível Superior - CAPES, por fomentar essa pesquisa durante o período de Doutorado, e pela oportunidade oferecida para realização desse sonho. 
Ao Centro de Excelência Ambiental da PETROBRÁS / Projeto PIATAM pela disponibilização de sala de estudos e todo o apoio logístico durante o curso.

Valter Dias Patrício e René Fernando Jimenez - proprietários da Geoambiental Norte e os servidores: Narislene Lopes, Heudes Lima, Rosane Santos, Paula Raskopf e Petra Mattos, pelos serviços gráficos.

Ao servidor Expedito dos S. P. S. Júnior, da Secretaria de Estado do Planejamento e Desenvolvimento (SEPLAN), lotado no Centro de Geotecnologia, Cartografia e Planejamento Territorial (CGPTERR), pelos serviços cartográficos.

Ao servidor Alexandre Pereira da Silva, Chefe de Divisão de Informática do Instituto de Terras e Colonização do Estado de Roraima - ITERAIMA, pelos serviços de tratamento de imagens.

A Emidio Neri Santiago Junior - Superintendente do Instituto Brasileiro do Meio Ambiente e dos Recursos Naturais Renováveis - Agência Boa Vista, pelo apoio com respeito ao planejamento de viagem para o baixo Rio Branco.

A Carlos Azevedo - Administrador do Água Boa Amazon Lodge (Hotel de Selva). Aos piloteiros: José Rodrigues (Zezinho), Samuel Almeida (Mutum), Ilson Costa (Bacaba), Jerbison Alves (Caboco), Jamin Batista (Irmão), Valdeir Goes (Preto). Cozinheira: Trícia Ferreira. Auxiliar de cozinha: Robson Tomaz. Garçom: Celso Augusto e Adam Cleiton. Camareira: Elenilde Ferreira e Cleane Bezerra. Manutenção: Juarez Ferreira.

A Wallace e Paula Porto, proprietários da Porto Tur - Pesca Esportiva. Loren Dinelli Diretora Administrativa e Financeira. Francisco Rodrigues - Gerente do Hotel Flutuante. Aos piloteiros: Izais dos Santos (Pixilingue), Francisco Leite, Daniel Rocha (Del), Cleudo Nascimento (Garimpeiro), Evaldo Garcia (Pezão), Renato Moura, Júlio da Silva (Tiririca), Marquison Sousa (Bebo). Cozinheiras: Idarminda Santos (Branca), Raimunda de Souza e Luzia Maia. Camareiras: Julia Silva e Antonieta Gonzalez. Garçonete: Michele Santos. Serviço Geral: Francisco Marçal. Auxiliar de Serviço Geral: Sandy Dun.

À minha esposa, Giselma Salete Tonelli Pereira de Souza, pelo constante incentivo, estímulo, paciência e pela compreensão pelas horas de convivência que lhe foram suprimidas.

Aos meus filhos Gabriela Pereira, Luiza Pereira, Ulysses Pereira de Souza, e a minha neta Claudia Medeiro, pelos momentos que lhes foram negados durante o período do curso. 
Apoio Logístico e Financeiro

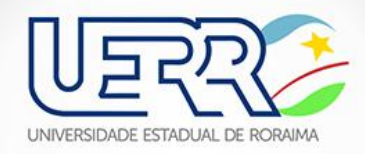

UNIVERSIDADE ESTADUAL 2 DE RORAIMA
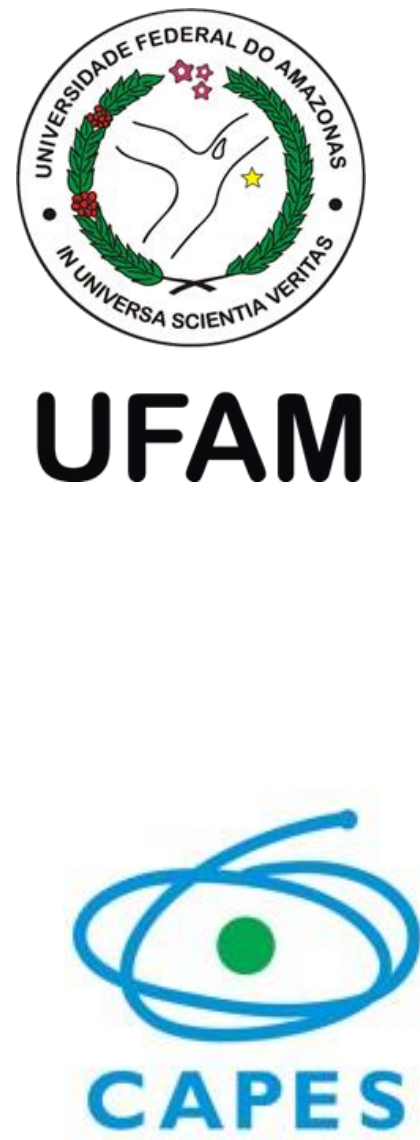 \\ PPGCIPET}




\section{RESUMO}

O conceito de capacidade de carga surge nas áreas da Ecologia, no manejo das pastagens, na década de 1930 nos Estados Unidos da América, como uso recreativo. Posteriormente passou a ser utilizada no campo do planejamento turístico com J. Alan Hagar, em sua publicação em 1964, intitulada The Carrying Capacity of Wild Lands for Recreation, onde define o nível de uso que uma área pode suportar sem afetar a sua qualidade, aplicado no manejo de visitantes em parques e reservas. A pesca tornou-se uma importante atividade recreativa para pessoas em todo o mundo, contribui para as economias de diversos países, gerando bilhões de dólares. No Brasil a expansão da pesca amadora ocorreu na década de 1990, inicialmente no Pantanal e hoje em todo o país. Na Amazônia ocorrem nos rios de água preta, em Roraima, no Rio Água Boa do Univini, devido à presença de grandes tucunarés (Cichla spp.). Considerando que o estabelecimento de um limite máximo de pescadores esportivos é um elemento que pode auxiliar no ordenamento da pesca, o presente estudo aplicou o método desenvolvido por Cifuentes et al. (1992) adaptada para o ambiente aquático, para estimar a capacidade de carga da pesca esportiva praticada embarcada no Rio Água Boa do Univini, a influência das unidades de conservação como fonte de reposição para os estoques de tucunarés e o perfil dos turistas praticantes na área de estudo. Para tanto, foram realizados experimentos no período da temporada de pesca esportiva do Estado de Roraima, compreendida entre outubro de 2018 a março de 2019 no Rio Água Boa do Univini, afluente da margem direita do Rio Branco, nos dois empreendimentos situados no referido rio. Para determinação da capacidade de carga física foi encontrado o resultado de 45 barcos motorizados de pesca utilizados no rio simultaneamente pelos dois empreendimentos. As capacidades de carga real e efetiva obtiveram os mesmos níveis da capacidade de carga física, que foram de 12 barcos pescando simultaneamente no rio. Quando se comparam os limites sugeridos com as taxas atuais de pescadores esportivos, verifica-se que a capacidade de carga está dentro do aceitável para a prática da pesca esportiva no Rio Água Boa do Univini. Influência da UC nos peixes capturados nas zonas de pesca. O tucunaré açu apresentou tamanho médio de 53 a $85 \mathrm{~cm}$, já o paca, 35 a $62 \mathrm{~cm}$; o tauá, com 10 a $35 \mathrm{~cm}$, e o borboleta, com 30 a $40 \mathrm{~cm}$. Em relação ao peso das quatro espécies, Açu peso médio de 3,5 a $6,5 \mathrm{~kg}$; paca, 2,0 a 5,0 kg; tauá, 0,4 a 1,8 kg e borboleta 1,0 a 1,8 kg. O número de peixes açu capturados foi 4 peixes grandes; paca, 25 médios a grande; tauá, 10 peixes, e borboleta, em maior quantidade, com 78 peixes. Aplicouse questionário aos pescadores esportivos nacionais e estrangeiros e guias de pesca como instrumento de pesquisa exploratória, com abordagem quantitativa e qualitativa. Os resultados mostram uma amplitude de idade variando de 30 a 90 anos, sendo $80 \%$ do sexo masculino e $20 \%$ do feminino; $85 \%$ são casados, e $70 \%$ têm curso superior. Apresentam uma renda superior a 10 salários mínimos e exercem profissões diversas, pescam mensalmente e semestralmente. Os guias de pesca apresentam uma larga experiência na função, variando de 10 a 22 anos de trabalho na área. Constata-se a identificação de ótimo potencial do turismo de pesca esportiva, desde que sejam tomadas medidas de estratégias de zoneamento de áreas de pesca e definição de cargas de exploração pela pesca esportiva embarcada.

Palavras-chave: Sustentabilidade. Pesca esportiva. Capacidade de carga. Reposição dos estoques pesqueiros. 


\begin{abstract}
The concept of load capacity arises in the areas of Ecology, in pasture management, in the 1930s in the United States of America, as recreational use. Later it was used in the field of tourism planning with J. Alan Hagar in his publication in 1964 entitled The Carrying Capacity of Wild Lands for Recreation where it defines the level of use that an area can support without affecting its quality, applied in the management of visitors in parks and reserves. Fishing has become an important recreational activity for people around the world, contributing to the economies of several countries, generating billions of dollars. In Brazil the expansion of amateur fishing occurred in the 1990s, initially in the Pantanal and today throughout the country. In the Amazon they occur in the rivers of black water, in Roraima on the Água Boa do Univini river, due to the presence of large tucunarés (Cichla spp.). Considering that the establishment of a maximum limit of sport fishermen is an element that can help in the management of fishing, the present study applied the method developed by Cifuentes et al. (1992) adapted to the aquatic environment, to estimate the load capacity of the sport fishing practiced on the Água Boa River of Univini, the influence of conservation units as a source of replacement for the stocks of tucunarés and the profile of practicing tourists in the area of study. For that, experiments were carried out during the period of the sport fishing season of the state of Roraima between October 2018 and March 2019 on the Água Boa do Univini river, a tributary of the right bank of the Branco river, in the two projects located in the river. For the determination of the physical load capacity was found the result of 45 motorized fishing boats used in the river simultaneously by the two enterprises. The actual and effective cargo capacities obtained the same levels of physical cargo capacity, which were 12 boats simultaneously fishing in the river. When comparing the suggested limits with the current rates of sport fishermen, it is verified that the load capacity is within the acceptable for the practice of sport fishing in the Água Boa do Univini river. Influence of UC on fish caught in fishing grounds. The tucunaré açu had an average size of 53 to $85 \mathrm{~cm}$, the paca 35 to 62 $\mathrm{cm}$, the taua with 10 to $35 \mathrm{~cm}$ and the butterfly with 30 to $40 \mathrm{~cm}$. In relation to the weight of the four species, Açu average weight of 3.5 to $6.5 \mathrm{~kg}$, paca 2.0 to $5.0 \mathrm{~kg}$, tauá 0.4 to $1.8 \mathrm{~kg}$ and butterfly 1.0 to $1.8 \mathrm{~kg}$. The number of fish, 4 fish captured, large paca 25 medium to large, tauá 10 fish and butterfly in larger quantity with 78 fish. A questionnaire was applied to national and foreign sport fishermen and fishing guides as an exploratory research instrument with a quantitative and qualitative approach, the results show a range of age ranging from 30 to 90 years, being $80 \%$ male and $20 \%$ female, $85 \%$ are married and $70 \%$ have a college degree, have an income of more than 10 minimum salaries and work in various professions, fish monthly and every six months. The fishing guides have a wide experience in the function, ranging from 10 to 22 years of work in the area. The identification of the great potential of sports fishing tourism should be verified, provided that measures are taken of zoning strategies of fishing areas and definition of cargoes of exploitation by the embedded sport fishing.
\end{abstract}

Keywords: Sustainability. Sport fishing. Loading capacity. Replenishment of fish stocks. 


\section{LISTA DE ILUSTRAÇÕES}

Figura 1 Unidades de Conservação presentes na área de estudo...............................................34

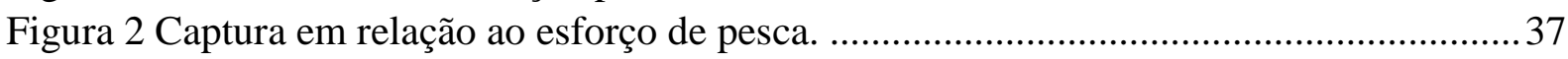

Figura 3- Mapa de localização da área de estudo................................................................. 41

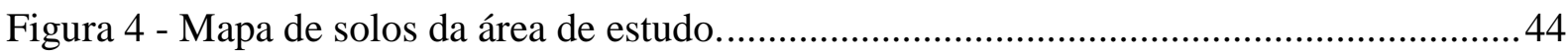

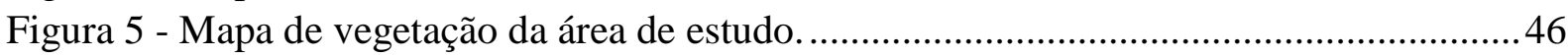

Figura 6- Água Boa Amazon Lodge. ................................................................................... 51

Figura 7 - País de origem dos pescadores esportivos na temporada 2018 - 2019 ..................52

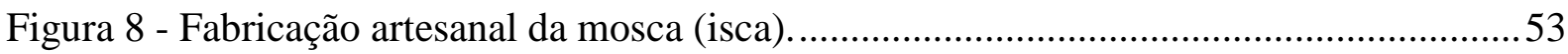

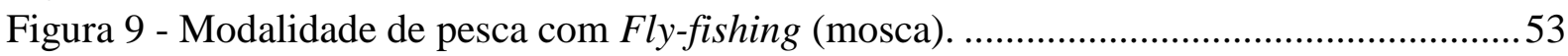

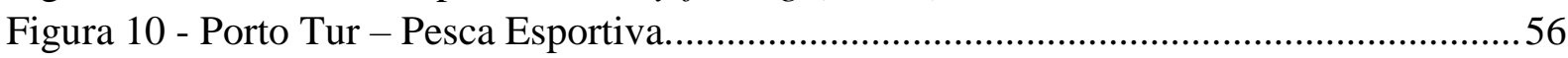

Figura 11 - Modalidade de pesca com carretilha e/ou molinete.............................................57

Figura 12 - Medidas de peso e de comprimento dos peixes capturados. .................................60

Figura 13 - Zona de pesca do Rio Água Boa do Univini. .........................................................62 62

Figura 14 - Representação esquemática dos níveis de capacidade de carga corrigidos. .........6 63

Figura 15 - Composição dos lagos e ressacas do Rio Água Boa do Univini. ........................... 74

Figura 16 - Coleta de lixos nos empreendimentos....................................................... 82

Figura 17 - Medidas de comprimento de tucunaré açú capturados nas zonas de pesca. .........86

Figura 18 - Medidas de comprimento do tucunaré paca nas zonas de pesca............................. 87

Figura 19 - Medidas de comprimento de tucunaré tauá capturados nas zonas de pesca. ........88

Figura 20 - Medidas de comprimento de tucunaré borboleta capturados nas zonas de pesca. 89

Figura 21 - Medidas de peso de tucunaré açú capturados nas zonas de pesca. .......................90

Figura 22 - Medidas de peso de tucunaré paca capturados nas zonas de pesca.......................90

Figura 23 - Medidas de peso de tucunaré tauá capturados nas zonas de pesca. ..................... 91

Figura 24 - Medidas de peso de tucunaré borboleta capturados nas zonas de pesca...............92

Figura 25 - Número de tucunaré açú capturados nas zonas de pesca. ...................................93

Figura 26 - Número de tucunaré paca capturados nas zonas de pesca. ...................................94

Figura 27 - Número de tucunaré tauá capturados nas zonas de pesca. ...................................95

Figura 28 - Número de tucunaré borboleta capturados nas zonas de pesca............................96

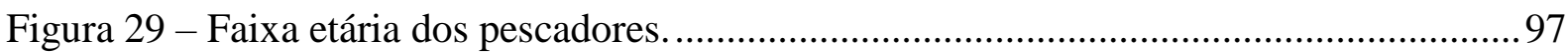

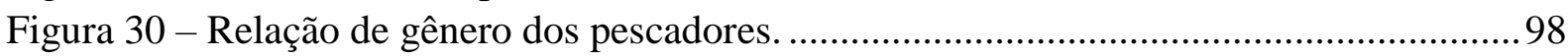

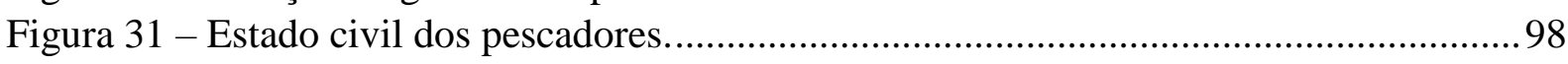

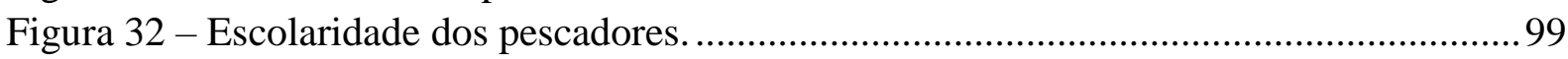

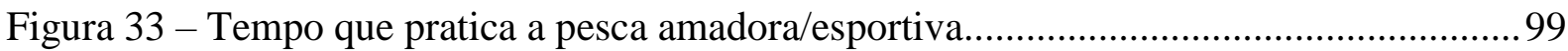

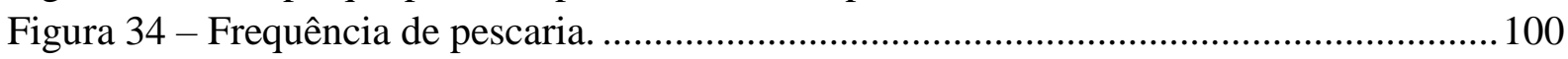

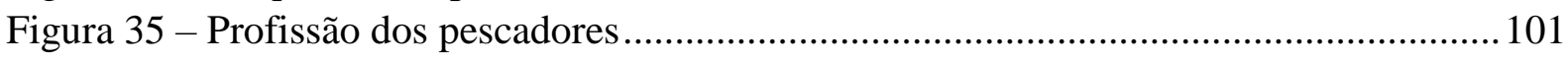

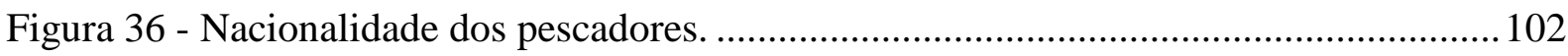

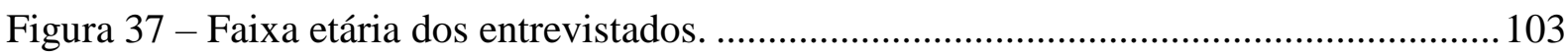

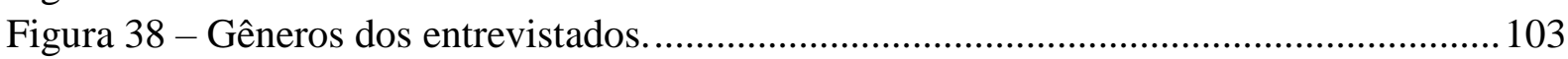

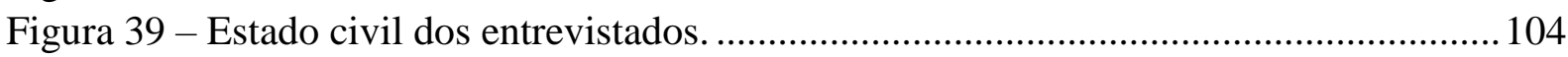

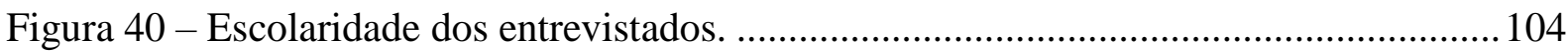

Figura 41 - Renda familiar dos entrevistados. ................................................................. 105

Figura 42 - Tempo que pratica a pesca esportiva. ............................................................. 105

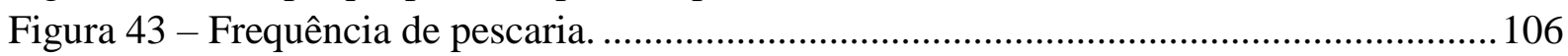




\section{LISTA DE TABELAS}

Tabela 1 - Variáveis usadas para determinar a capacidade de carga........................................ 70

Tabela 2 - Unidades de conservação e respectivas áreas do Estado de Roraima. .....................73 Tabela 3 - Localização, dimensão e profundidade média dos corpos d'água do Rio Água Boa do Univini, no período de outubro de 2018 a março de 2019. Roraima, Brasil...................... 75 Tabela 4 - Descrição geral da Capacidade Instalada (CI) e da Capacidade Adequada (CA) do Água Boa Amazon Lodge que atua no Rio Água Boa do Univini, Roraima, Brasil. 83 Tabela 5 - Descrição geral da Capacidade Instalada (CI) e da Capacidade Adequada (CA) da Porto Tur - Pesca Esportiva que atua no Rio Água Boa do Univini, Roraima, Brasil. ............83 Tabela 6 - Capacidade de Manejo dos empreendimentos que operam no Rio Água Boa do Univini, Roraima, Brasil..... 
LISTA DE ABREVIATURAS E SIGLAS

\begin{tabular}{|l|l|}
\hline ANAC & Agência Nacional de Aviação Civil \\
\hline ANEPE & Associação Nacional de Ecologia e Pesca Esportiva \\
\hline CCF & Capacidade de Carga Física \\
\hline CCR & Capacidade de Carga Real \\
\hline CCE & Capacidade de Carga Efetiva \\
\hline CM & Capacidade de Manejo \\
\hline CA & Capacidade Adequada \\
\hline CI & Estação Ecológica \\
\hline ESEC & Estação Ecológica do Niquiá \\
\hline ESEC NIQUIÁ & Fundação Estadual do Meio Ambiente e Recursos Hídricos \\
\hline FEMARH & Faculdade de Ciências Agrárias \\
\hline FCA & Fatores de Correção \\
\hline FC & Fatores Limitantes \\
\hline FL & $\begin{array}{l}\text { Instituto Brasileiro do Meio Ambiente e dos Recursos } \\
\text { Naturais Renováveis }\end{array}$ \\
\hline IBAMA & Instituto Brasileiro de Geografia e Estatística \\
\hline IBGE & Instituto de Ciências Biológicas \\
\hline ICB & Ministério da Pesca e Aquicultura \\
\hline MPA & Ministério do Meio Ambiente \\
\hline MMA & Parque Nacional \\
\hline PARNA & Parque Nacional Serra da Mocidade \\
\hline PARNA SERRA DA \\
MOCIDADE & $\begin{array}{l}\text { Programa de Pós-Graduação em Ciências Pesqueiras nos } \\
\text { Trópicos }\end{array}$ \\
\hline PPG - CIPET & Pró-Reitoria de Pesquisa e Pós-Graduação \\
\hline PROPESP & Pontos de Referência Biológicos \\
\hline PRB & Reserva Biológica \\
\hline REBIO & Sistema Nacional de Unidade de Conservação \\
\hline SNUC & Unidade de Conservação \\
\hline UC & Universidade Federal do Amazonas \\
\hline UFAM & \\
\hline
\end{tabular}


SUMÁRIO

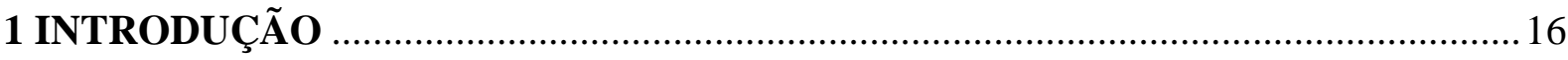

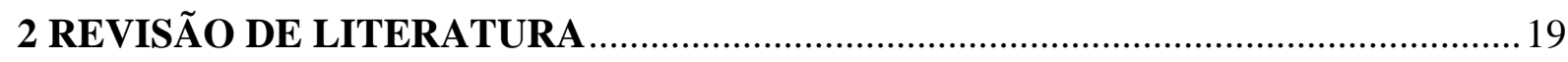

2.1 ESPÉCIE-ALVO EXPLORADA PELA PESCA ESPORTIVA.........................................19

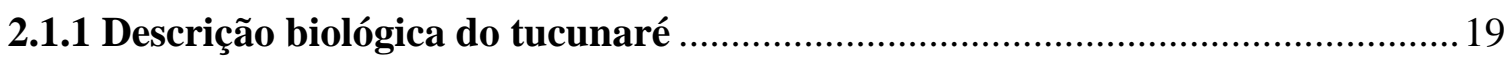

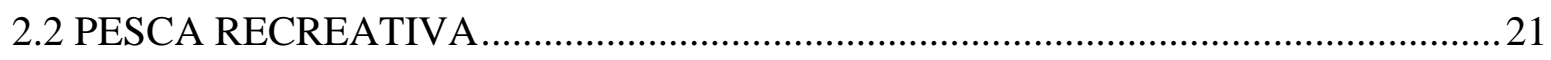

2.3 PESCA ESPORTIVA - MODALIDADE PESQUE-E-SOLTE …………………….....23

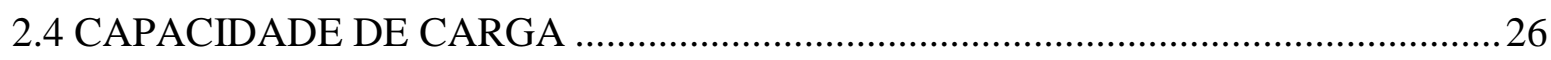

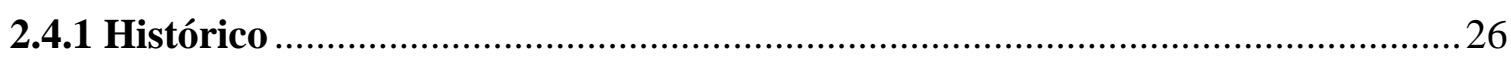

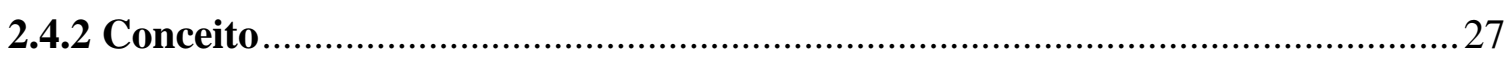

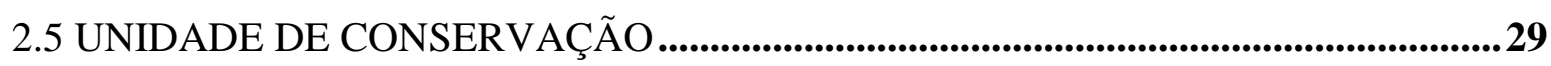

2.5.1 Sistema Nacional de Unidade de Conservação da Natureza ..................................30

2.6 REPOSIÇÃO DO ESTOQUE PESQUEIRO ...................................................................35

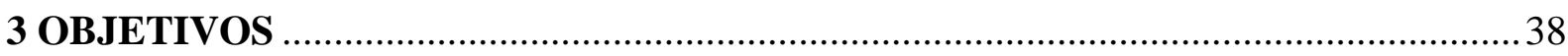

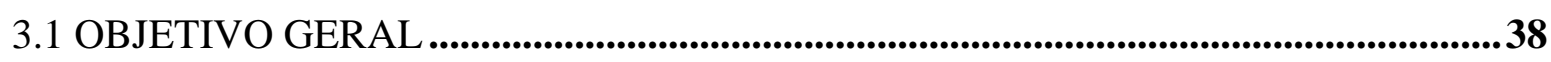

3.2 OBJETIVOS ESPECÍFICOS …......................................................................38

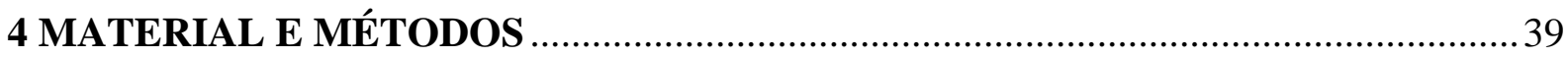

4.1 ÁREA DE ESTUDO ...............................................................................................39

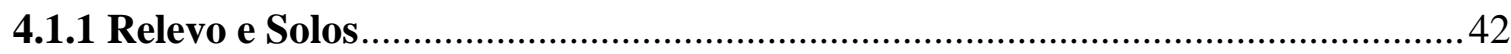

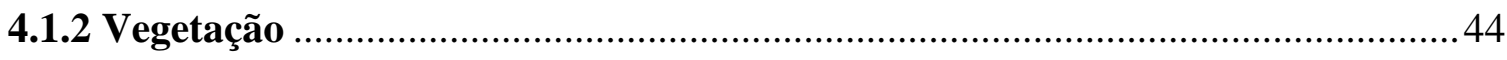

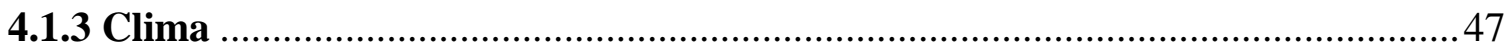

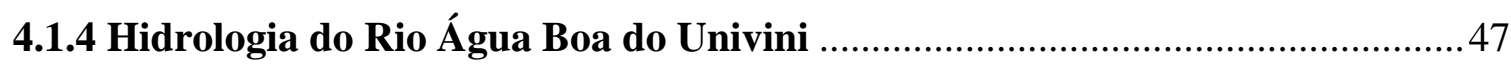

4.2 COLETA DE DADOS..........................................................................................................49

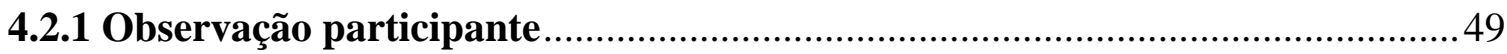

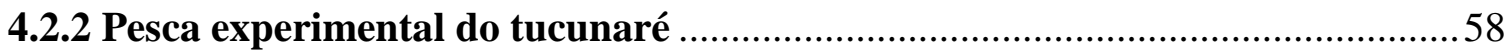

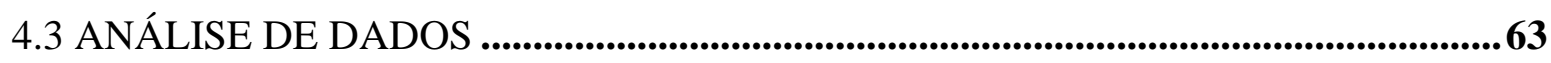

4.3.1 Definição das Capacidades de Cargas ……………………………………….......63

4.4 DETERMINAÇÃO DAS CAPACIDADES DE CARGAS .............................................64

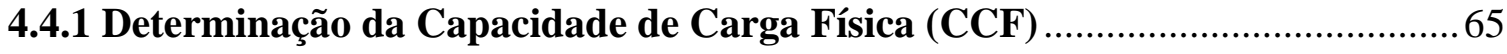

4.4.2 Determinação da Capacidade de Carga Real (CCR) ............................................66

4.4.3 Determinação da Capacidade de Carga Efetiva ou Permissível (CCE).............67

4.4.3.1 Limite Aceitável de Uso - LAU .........................................................................................70

4.5 CAPACIDADE DE RENOVAÇÃO DO ESTOQUE PESQUEIRO .................................70

4.5.1 Influência da unidade de conservação no estoque pesqueiro …………………....72

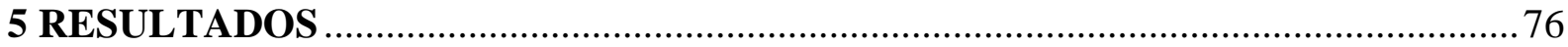


5. 1 CAPACIDADE DE CARGA RECREATIVA DAS EMBARCAÇÕES DE PESCA ESPORTIVA NO RIO ÁGUA BOA DO UNIVINI .......................................................76

5.1.1 Capacidade de Carga Física (CCF) ....................................................................76

5.1.2 Capacidade de Carga Real (CCR) ...................................................................78

5.1.3 Capacidade de Carga Efetiva (CCE) ...............................................................82

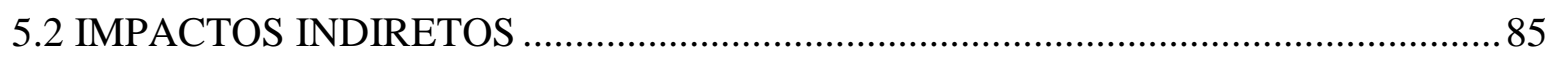

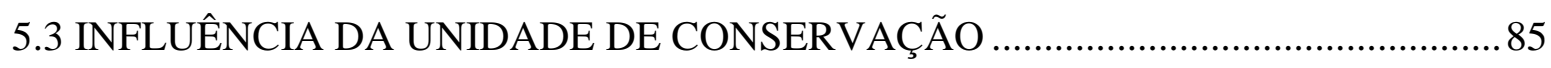

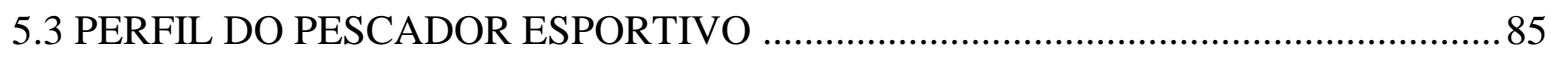

5.3.1 Pescador esportivo estrangeiro ......................................................................96

5.3.2 Pescador esportivo nacional .............................................................................102

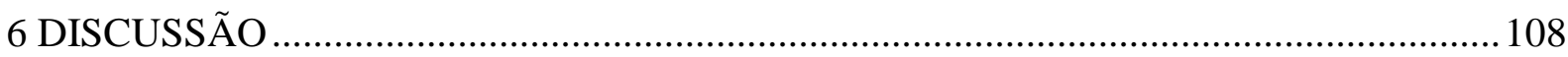

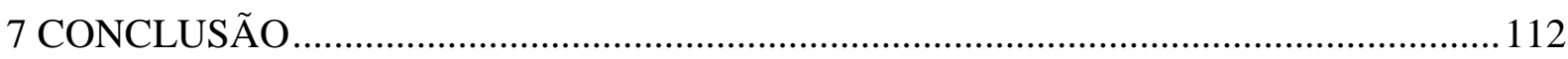

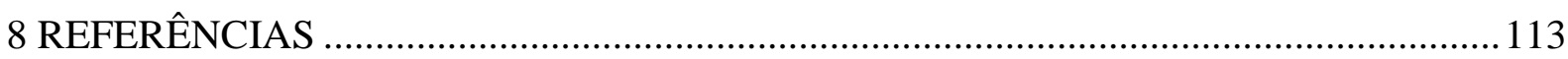

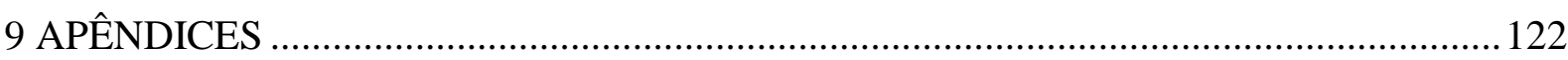




\section{INTRODUÇÃO}

Desde os primórdios dos tempos, a pesca é de fundamental importância à sobrevivência do homem e é impossível precisar o início da pesca, enquanto atividade de exploração de recursos aquáticos, na história da humanidade. Como ainda não se havia desenvolvido as formas de cultivo tradicionais de terra e criação de animais, muitas das sociedades primitivas dependiam quase que exclusivamente da pesca como fonte de alimentos. Com a evolução da humanidade a pesca disseminou pelo mundo, e passou de essencial para a vida do homem, como fonte para alimentação, para uma paixão, surgindo então a pesca por lazer e entretenimento. Para Ditton et al. (2002), a popularidade da atividade de pescaria se dá por dois motivos principais: o custo relativamente baixo e a nãonecessidade de preparo físico para a prática da atividade.

Conforme Henry e Maria Yvonne (2005) existem diferenças conceituais entre pesca amadora e esportiva. A pesca amadora, praticada pela grande maioria dos pescadores, diferencia-se da pesca profissional por seu caráter não comercial. Seu objetivo é proporcionar a seu praticante horas de prazer em contato com a natureza, relaxamento e contemplação, enquanto a pesca esportiva é uma atividade competitiva entre pessoas ou grupos. Ainda segundo Henry e Maria Yvonne (2005), considerando esse contexto, depois de estabelecida na mente dos pescadores a imagem da pesca como lazer ou esporte, foi necessária a conscientização dos períodos adequados para a pesca de determinadas espécies e da conservação de espécies mais raras, ou seja, houve aumento das preocupações ambientais nas últimas décadas do século XX. Assim sendo, o conceito de pesca esportiva também passou a ser utilizado para o sistema de pesca com devolução do peixe à água, estabelecendo-se a filosofia conhecida como catch and release, que, em Português, significa "pesque-e-solte".

Segundo Cooke e Suski (2005), a pesca tornou-se uma importante atividade recreativa para pessoas em todo o mundo. A pesca recreativa contribui para as economias de diversos países, gerando bilhões de dólares em receitas diretas e indiretas geradas pelo Turismo (Granek et al., 2008), sendo hoje altamente desenvolvida e perseguida por um grande número de pessoas, principalmente por prazer, mas também pela geração de renda e pelo complemento da oferta de alimentos (COOKE e COWX, 2004), impulsionando um segmento industrial altamente desenvolvido (ALBANO, VASCONCELOS, 2013).

O gerenciamento em alguns países como Estados Unidos, Nova Zelândia, Chile, Canadá e Argentina fazem da pesca amadora uma atividade capaz de gerar receitas 
significativas, viabilizando recursos não só para o seu próprio desenvolvimento, como também para serem aplicados na conservação do meio ambiente. Se realizada de forma planejada, a pesca amadora pode tornar-se uma grande aliada das ações de regulamentação da atividade pesqueira em seu conjunto (RUFFINO, 2005).

Nos Estados Unidos da América estima-se que cerca de 40 milhões de norteamericanos, maiores de 16 anos, aproveitaram as variedades da pesca sem finalidade comercial no ano de 2008, totalizando 45 bilhões de dólares investidos com a prática da pesca amadora (BRASIL, 2010). Segundo Fabri (2006) o Turismo de Pesca amadora no Brasil teve grande expansão desde o começo da década de 1990, inicialmente evidenciado no Pantanal, e hoje se configura em uma realidade de Norte a Sul do território brasileiro. Estima-se que hoje existem 25 milhões de pescadores amadores no país.

No Brasil, nos últimos 10 anos, houve um crescimento fantástico da pesca amadora. $\mathrm{O}$ que era uma atividade de lazer transformou-se em uma indústria cada vez mais forte, que movimenta milhões de reais anualmente, em segmentos tão diversos como importação e exportação de equipamentos de pesca, aquicultura, Turismo e mídia especializada (BARROCO, 2013; RUFFINO, 2005).

Henry e Maria Yvonne (2005) afirmaram que o Brasil ainda não explora de maneira adequada toda a sua potencialidade para atrair o pescador amador, mesmo possuindo uma rede hidrográfica de $8.400 \mathrm{~km}$ de costa atlântica e redes hidrográficas aliadas a uma enorme diversidade de peixes. Segundo estes pesquisadores, o Brasil é o país com o maior número de espécies de seres vivos e possui cerca de 2.500 espécies de peixes, o que corresponde a $10 \%$ da fauna de peixes de águas doces do planeta.

Definida como a modalidade praticada por brasileiros ou estrangeiros com a finalidade de lazer, turismo e desportos sem finalidade comercial (IBAMA, 2009), a pesca amadora está dividida em três categorias: pesca desembarcada, pesca embarcada e pesca subaquática. Quanto à pesca esportiva, independente da categoria, é uma sub modalidade da pesca amadora, na qual a prática do pesque-e-solte é obrigatória (SOUZA et al, 2015).

Segundo Reis et al. (2016) a Bacia Amazônica apresenta uma rica ictiofauna, com 57 famílias, 525 gêneros e 2.411 espécies. Destes, 111 gêneros (21\%) e 1.089 espécies (45\%) são endêmicos da Bacia Amazônica. Como na maior parte da América do Sul, os estudos mostram que a fauna de peixes da Bacia Amazônica é formada por vários grupos, entre eles os ciclídeos. Algumas espécies de peixes amazônicos são consideradas fundamentais e 
importantes na pesca esportiva, devido principalmente ao seu ataque à isca e seu comportamento agressivo, o que caracteriza um grande esforço de fuga no momento em que é fisgado pelo pescador esportivo.

A pesca amadora/esportiva na Bacia Amazônica vem crescendo a cada ano. Esse crescimento, segundo Freitas e Rivas (2006), está diretamente relacionado à presença de grandes exemplares de tucunarés Cichla sp., considerado o grande embaixador da pesca esportiva na Amazônia. O comportamento agressivo dessa espécie vem atraindo aficionados pela pesca esportiva em todo o mundo, um contingente de pescadores amadores nacionais e estrangeiros ávidos pelo divertimento e conhecimento da biodiversidade amazônica, gerando um aporte financeiro significativo para a economia dessas regiões (FREITAS; RIVAS, 2006).

Com o advento da divulgação, na mídia nacional e internacional, de que a região do baixo rio Branco, em Roraima, é um ambiente favorável para a prática do pesque-e-solte, devido à presença de grandes tucunarés, cerca de 2.000 pescadores esportivos vêm visitando a região anualmente, aumentando muito a pressão sobre os estoques naturais de tucunarés. Sendo os rios Água Boa do Univini, Itapará e Xeriuini os locais preferenciais para a prática da pesca esportiva (SOUZA, FREITAS, 2019, no prelo).

Segundo Silva e Lima (2015), muito embora Roraima disponha de um grande potencial para a pesca esportiva, o estado ainda carece de políticas públicas e projetos para criar mecanismos e instrumentos para que as comunidades envolvidas possam se beneficiar mais equitativamente e diretamente do Turismo de pesca esportiva, dando a devida relevância para o elemento "humano" e "social" neste segmento.

De acordo com Vaz (2012), apesar do acelerado desenvolvimento da pesca amadora nos últimos anos no país, esta ainda é pouco estudada, dificultando a formação de uma base de dados que possa nortear as políticas públicas federais, estaduais e municipais para esse setor pesqueiro. Os poucos trabalhos desenvolvidos são, na sua maioria, análises pontuais de alguma região ou município, ou de algum segmento específico como o comércio de isca viva.

Dentro dessa perspectiva, o presente estudo teve como finalidade analisar a atual situação da pesca esportiva no Estado de Roraima, com o intuito de discutir a viabilidade social, econômica, ecológica e ambiental da atividade, por meio da determinação da capacidade de carga da pesca esportiva embarcada no Rio Água Boa do Univini, na região do baixo Rio Branco, no Estado de Roraima. 
A escolha dessa área foi motivada por tratar-se de uma região com uma paisagem ainda inalterada, apresentando-se como um cenário ideal para a prática da pesca esportiva, ambientes com águas translúcidas e uma rica ictiofauna, destacando-se o tucunaré (Cichla spp.), peixe que vive nos lagos, lagoas e beira de rios, sendo considerado o embaixador da pesca esportiva na Amazônia.

Um dos problemas encontrados na realização desse estudo foi a dificuldade de acesso à bibliografia referente ao tema, isto é, sobre determinação da capacidade de carga em ambiente aquático, e a falta de dados sobre as reais consequências da aplicação do uso dessa metodologia em atividades recreativas sobre os diferentes recursos naturais no Brasil.

Como forma de prover esta deficiência, elaborou-se um referencial teórico do trabalho, que versa acerca dos possíveis impactos causados pelas atividades recreativas, sobre os diferentes recursos naturais, e dos fatores que influenciam nas diferentes respostas do ambiente frente ao uso. Desta maneira, discutiu-se o conceito de capacidade de carga para a pesca esportiva em Roraima, as dificuldades de sua aplicação e sua importância como marco teórico no planejamento e manejo das atividades recreativas, em especial, a pesca esportiva em ambiente natural. Neste sentido, a capacidade de carga de pesca esportiva embarcada figura como um instrumento relevante para o processo de planejamento turístico de áreas ambientalmente sensíveis.

\section{REVISÃO DE LITERATURA}

\subsection{ESPÉCIE-ALVO EXPLORADA PELA PESCA ESPORTIVA}

\subsubsection{Descrição biológica do tucunaré}

Espécies do gênero Cichla, pertencentes à ordem Perciformes, família Cichlidae, estão entre os principais atrativos do Turismo de Pesca esportiva na América do Sul. Eles são conhecidos localmente pelos nomes coletivos de tucunaré na maior parte da Região Amazônica, pavón na Venezuela, toekoenali no Suriname e lukanani na Guiana (KULLANDER, 2003). A denominação tucunaré é dada a esses peixes por causa dos grandes pontos oculares nas caudas (MUELRATH; MUELRATH, 2012). A razão básica para estes ocelos é confundir outros peixes pequenos em acreditar que isto é o fim da cabeça, há espécies de peixe nas águas de Rio Amazonas cuja única dieta consiste nas barbatanas de 
outros peixes (MUELRATH; MUELRATH, 2012). As espécies do genêro Cichla, de acordo com Kullander e Ferreira (2006), (PRICE'S, 2009) que se encontram no Rio Água Boa do Univini, constituindo a base para a pesca esportiva nesse rio são: Cichla monoculus (SPIX \& AGASSIZ, 1831), Cichla orinocensis (HUMBOLDT, 1821), Cichla ocellaris (SCHNEIDER, 1801) e Cichla temensis (HUMBOLDT, 1821).

Segundo Kullander e Ferreira (2006), existem quinze espécies nominais referentes ao gênero Cichla, que são classificadas de acordo com características merísticas e padrões de cor, variando com a espécie e o tipo de água em que habitam. Estão descritas, catalogadas e sistematizadas da seguinte forma: Cichla ocellaris (SCHNEIDER, 1801), Cichla orinocensis (HUMBOLDT, 1821), Cichla nigromaculata (JARDINE, 1843), Cichla monoculus (AGASSIZ, 1831), Cichla kelberi, Cichla pleiozona, Cichla mirianae, Cichla melaniae, Cichla piquiti, Cichla thyrorus, Cichla jariina, Cichla pinima, Cichla vazzoleri, Cichla temensis (HUMBOLDT, 1821) e Cichla intermedia (MACHADO-ALLISON, 1971). As principais características desta família é a presença de uma linha lateral dividida em dois ramos e uma boca protrátil com mobilidade no pré-maxilar (GASQUES et al., 2014), caracterizados por espinhos nas nadadeiras (SANTOS; SANTOS, 2005). Ainda de acordo com Kullander e Ferreira (2006), a diversidade de espécies de Cichla é muito maior do que a indicada pela literatura atual. Algumas espécies ainda são conhecidas apenas como espécimes. Devido à imensa área geográfica não foram amostrados todos os peixes desse genêro e é provável que existam entre 20 e 30 espécies de Cichla (KULLANDER; FERREIRA, 2006).

Os tucunarés habitam preferencialmente ambientes lênticos, ou seja, lagos e lagoas, margens dos rios, nas entradas de lagoas conectadas a rios, remansos, canais fluviais e áreas sazonalmente alagadas com prensença de troncos, galhos de árvores, vegetação nos lados e pedras. Os tucunarés são considerados sendentários, mas podem se deslocar nos canais dos rios, princialmente no auge da estação seca (BARTHEM et al., 1997). São animais piscívoros (FERREIRA et al., 2007), com um comportamento adaptativo de alimentação, é notável quando comparado com outras espécies de peixes da Amazônia, alimentando-se de uma variedade de invertebrados e algumas espécies de planta (KULLANDER, 2003).

Dentre os ciclídeos neotropicais, o gênero Cichla possui as espécies de maior tamanho, podendo alcançar cerca de 1 metro em Cichla temensis (KULLANDER, 2003) e podendo atingir até $12 \mathrm{~kg}$, sendo de importância econômica na pesca comercial e recreativa (KULLANDER; FERREIRA, 2006). Sua importância na pesca esportiva é devido ao seu 
comportamento agressivo em relação aos outros peixes (KELBER, 1999) o que atrai os aficionados pela pesca esportiva de todo o mundo (FREITAS; RIVAS, 2006).

Segundo Daniel (2014), a desova é parcelada, podendo se reproduzir durante todo ano. Seus ninhos de desova circulares são fáceis de detectar nos substratos de lagos e lagoas, os ovos são adesivos e o casal toma conta deles e dos filhotes (MUELRATH e MUELRATH, 2012). De acordo com Lorenzo (2014), estes peixes não apresentam uma época reprodutiva definida, porém, se reproduzem com maior frequência durante os meses mais quentes. Segundo Horie (2014), o início do período reprodutivo de Cichla é caracterizado pelo aparecimento, nos machos, de uma protuberância pós-occipital de conteúdo adiposo, denominada popularmente de "gibão". Os machos escolhem as fêmeas que possam produzir o maior número de descendentes, enquanto as fêmeas escolhem os machos que poderão defender o seu território e o ninho.

De acordo com Kelber (1999), quando se encontram solitários ou em período de acasalamento, os tucunarés são extremamente territoriais. Seu comportamento pode se tornar muito agressivo quando outros predadores tentam atacar suas áreas de berçário. São pais protetores de filhotes, mantendo-os em segurança escondidos dentro de sua enorme boca, eles defendem os ninhos e os recém-nascidos com uma ferocidade surpreendente (MUELRATH, MUELRATH, 2012).

\subsection{PESCA RECREATIVA}

Segundo Cooke e Cowx (2004), a pesca comercial e a recreativa são fontes importantes de proteína e contribuem com benefícios econômicos substanciais para as economias locais e nacionais. Ainda de acordo com os autores, a pesca recreativa é diferente da pesca comercial, sendo o lazer o principal motivo, embora isso não impeça que a pesca seja tomada para consumo doméstico, enquanto a pesca comercial é gerida especificamente para capturar produtos de peixe à venda.

A pesca recreativa é uma busca natural, culturalmente evoluída, que é social e legalmente aceita pela maioria das sociedades em todo o mundo (ARLINGHAUS et al., 2009).

Ainda de acordo com Cooke e Cowx (2006), as tendências globais das capturas de pescado marinho e de água doce geralmente estão aumentando. Porém, esses aumentos disfarçam a verdadeira situação das pescarias mundiais. As principais pescas comerciais estão sujeitas à intensa exploração e a captura por unidade de esforço está diminuindo em muitas pescarias. Como consequência, nas novas pescarias estão sendo procuradas espécies de 
crescimento lento, espécies de baixo valor comercial, ou aquelas que ocupam um nível trófico inferior.

A despeito da percepção de que a pesca recreativa é uma atividade benigna, sua participação mundial é crescente (COOKE e COWX, 2006). Globalmente, a pesca recreativa é hoje altamente desenvolvida e perseguida por um grande número de pescadores recreativos, principalmente por prazer, mas também pela geração de renda e pelo complemento da oferta de alimentos. Embora as pescas comerciais colham mais peixes do que as pescas recreativas numa base global, o inverso também pode ser observado, ou a captura recreativa pode contribuir significativamente para a captura global de uma pescaria em particular.

Esses autores relataram que há muitos casos em que as pescas comerciais foram restringidas devido a preocupações com a estrutura populacional e a abundância, e em compensação, houve aumento das pescas recreativas. Como por exemplo, o tambor vermelho (Sciaenops ocellatus) tornou-se popular durante a década de 1990, e, quando os estoques foram observados em declínio no Golfo do México, as pescarias comerciais foram reduzidas, e em contrapartida, a pesca recreativa expandida.

A modalidade de pesca no sistema "pesque-e-solte" vem crescendo substancialmente nos Estados Unidos e é cada vez mais importante para os pescadores recreativos norteamericanos. A indústria da pesca desportiva incentiva os pescadores a libertarem, voluntariamente, o peixe como forma de pesca recreativa, além de porporcionar novos regulamentos para o peixe ser libertado nas pescarias recreativas e também nas comerciais. Outra tendência para promover a pesca sustentável e proteger os ecossistemas aquáticos é estabelecer áreas aquáticas protegidas, incluindo reservas de pesca (NTRs da sigla em inglês No-Take Reserves) onde as atividades extrativistas são proibidas, permitindo a pesca recreativa porque a mesma não é extrativista (BARTHOLOMEW; BOHNSACK, 2005).

Nos Estados Unidos da América as capturas da pesca recreativa das seguintes espécies de peixes: robalo baixo listrado (Morone saxatilis), anchova (Pomatomus saltatrix), robalo (Serranidae), golfinho (Coryphaena hippurus), peixe vermelho (Sebastes marinus) e o tautog (Tautoga onitis) ao largo da costa leste americana excedeu o das pescas comerciais (COOKE; COWX, 2006).

No Brasil, a ictiofauna apresenta cerca de 3.290 espécies de água doce e 1.209 espécies marinhas (FROESE \& PAULY 2015), representando 14\% da diversidade mundial de peixes. Esta alta diversidade está fortemente relacionada com a heterogeneidade de habitats e clima, proporcionando oportunidades excelentes de pesca recreativa. Zeinad e Prado (2012) descreveram 114 espécies de peixes de água doce em todo o país, com características 
interessantes para a pesca recreativa. Enquanto para águas marinhas, os mesmos pesquisadores descreveram menor quantidade de peixes recreativos, a contagem foi inferior a 60 espécies.

Segundo Freire et al. (2016), a pesca recreativa surgiu no Brasil como atividade de lazer no século XIX, quando a primeira citação dessa modalidade de pesca ocorreu no livro publicado em 1863, de autoria de Magalhães, intitulado 'Viagem ao Araguaya'. De acordo com os autores, a Região Norte, na maior parte incluída na Amazônia brasileira, emergiu como um destino mais recente para os estabelecimentos recreativos no Brasil, sendo o tucunaré (Cichla spp.) a principal espécie alvo. A modalidade de pesca pesque-e-solte é a prática dominante entre os praticantes recreativos nacionais e estrangeiros na região.

Para o Estado de Roraima, Filho et al. (2005) encontraram potencial para o desenvolvimento de peixes de recreio ao longo do baixo Rio Branco, nos seguintes rios: Água Boa do Univini, Xeruini e Itapará. Os pescadores amadores capturaram principalmente Cichla spp., Boulengerella spp., Serrasalmus spp. e Hoplias spp. O aumento do potencial da pesca amadora na região proporcionou a existência de empresas operando o Turismo de Pesca Esportiva na região.

\subsection{PESCA ESPORTIVA - MODALIDADE PESQUE-E-SOLTE}

A pesca amadora é a modalidade definida como "aquela praticada por brasileiros ou estrangeiros com finalidade de lazer, turismo e desporto, sem finalidade comercial", dividida em três categorias: pesca desembarcada, embarcada e subaquática (IBAMA, 2009). Ainda de acordo com o Instituto Brasileiro do Meio Ambiente e dos Recursos Naturais Renováveis, ocorrem dois tipos de pesca: a pesca amadora e a pesca esportiva. A pesca amadora é representada por toda atividade pesqueira de natureza não comercial, caracterizada por hobby ou esporte, em que o praticante não depende desta atividade para sobreviver, isto é, essa pesca é praticada como atividade lúdica, com o objetivo de recreação. Enquanto para o Ministério da Pesca e Aquicultura (MPA, 2010); (CHAVES e FREIRES, 2012); (SOUZA et al., 2014), a pesca esportiva é classificada como "uma modalidade da pesca amadora em que é obrigatória a prática do pesque-e-solte, sendo vedado o direito à cota de transporte de pescado, prevista na legislação". Souza et al. (2014) salientam que a pesca esportiva é uma atividade que está crescendo em ritmo acelerado no país, onde os pescadores praticantes do pesque-e-solte (liberar o peixe com vida logo após a captura) é praticada obrigatória em rios da Amazônia (FREITAS e RIVAS, 2006; HOLLEY et al., 2008) e do Pantanal (CATELLA, 2004). 
Para Chaves e Freire (2012), não se sabe ao certo quando a prática da soltura de peixe começou. Entretanto, Policansky (2008) relata que a atividade da soltura de peixe é uma prática tão antiga quanto a própria pesca. Para Tufts et al. (2000), a libertação do peixe já vinha sendo proposta desde 1870 para a manutenção do recurso pesqueiro, mas sua efetiva utilização como medida de conservação começou a partir do final da década de 40 e início da década de 50, nos Estados Unidos da América. Barnhart (1989) cita que a primeira ocorrência da libertação do peixe na pesca data de 1954, no Great Smoky Mountains National Park, nos Estados Unidos da América. Por outro lado, Juliana Bernes, no livro Treatyse of Fysshynge wyth an Angle, publicado na Inglaterra em 1496, relata o primeiro registro notificado de pesca como atividade de recreação. O livro inclui informações sobre locais de pesca, manufatura de varas e linhas de pesca, uso de iscas naturais e também confecção e uso de iscas artificiais, além de conceitos conservacionistas (BRASIL, 2010). Petrere Jr (2014) relata também que provavelmente a pesca amadora do tipo pesque-solte (catch and release fishing) tenha iniciado no Reino Unido há mais de um século, e se espalhou pelo mundo. No Brasil, segundo Vaz (2012), o primeiro registro de pesca amadora foi relatado por Couto Magalhães, em 1863 em seu livro 'Viagem ao Araguaia', onde o autor descreve a pesca não somente como fonte de alimento, mas também como atividade de lazer e recreação. Ainda de acordo com o autor, no ano de 1934 foi publicado o Decreto $\mathrm{n}^{\mathrm{o}}$ 23.672, de 02 de janeiro, na qual o Governo Brasileiro institui a obrigatoriedade de uma licença para a prática da pesca amadora, a proibição da comercialização do pescado capturado por pescadores amadores, bem como um registro especial no Serviço de Caça e Pesca para os clubes ou associações de pescadores amadores, iniciando assim, a regulamentação da atividade de pesca amadora no país.

A partir das primeiras ocorrências do pesque-e-solte, vários países têm adotado essa prática no sentido de conservação de seus recursos pesqueiros. Ao longo desse período, diversas mudanças foram observadas no comportamento dos pescadores esportivos e melhorias das artes de pesca por eles utilizadas (CHAVES; FREIRE, 2012).

O Turismo de Pesca atualmente é um dos segmentos turísticos que evidencia maior crescimento no mundo. Nos Estados Unidos da América, por exemplo, estima-se que cerca de 40 milhões de norte-americanos, de 16 anos ou mais, aproveitaram as variedades da pesca sem finalidade comercial no ano de 2008, totalizando 45 bilhões de dólares investidos com a prática da pesca amadora (BRASIL, 2010). Segundo Fabri (2006) o Turismo de Pesca amadora no Brasil teve grande expansão desde o começo da década de 1990, inicialmente 
evidenciado no Pantanal, e hoje se configura em uma realidade de Norte a Sul do território brasileiro. Estima-se que hoje existem 25 milhões de pescadores amadores no país.

O grande potencial dos recursos pesqueiros brasileiro é suficiente para atrair pescadores do todo o mundo, recursos estes representados pela diversidade da ictiofauna em diferentes biomas, pelas vastas bacias hidrográficas, com lagos, lagoas, manguezais, reservatórios de hidrelétrica e, aproximadamente oito mil quilômetros de costa, proporcionando diversas opções para a prática da pesca (BRASIL, 2010).

Segundo Lorenzo (2013), a relação entre a pesca praticada por lazer e o segmento turístico se tornou evidente no Brasil somente em 1998 com a atenção da gestão pública brasileira voltada ao pescador amador, através da criação do Programa Nacional de Desenvolvimento da Pesca Amadora - PNDPA, pelo Ministério do Esporte e do Turismo (EMBRATUR) e o Ministério do Meio Ambiente (MMA). O programa foi criado com o propósito de transformar essa modalidade de pesca em um vetor de desenvolvimento econômico, social e de conservação ambiental do País.

No Brasil, a pesca praticada por lazer é favorecida em decorrência da diversidade de ecossistemas, a diversidade de peixes, adicionadas a belezas naturais existentes, Isso tudo faz do país um destino de pesca consolidado e bastante procurado por turistas nacionais e estrangeiros (VAZ, 2012). Assim, de acordo com o antigo Ministério da Pesca e Aquicultura, quase todas as regiões do país possuem características propícias para o desenvolvimento dessa modalidade de pesca, como a Amazônia, o Pantanal e também as regiões Sudeste, CentroOeste e Sul do País, com seus rios, represas, baías, açudes e estuários (BRASIL, 2010). Porém, de acordo com Souza e Cañete (2015), o recorte da pesca esportiva ganha robustez quando se trata da Região Amazônica, em virtude da presença de rios, lagos, igarapés, igapós e do ciclo das águas, os quais formam sazonalidades específicas para a captura de diferentes espécies de peixes.

Segundo Filho et al. (2005), a pesca esportiva atualmente na Região Amazônica é uma das atividades com maior potencial de desenvolvimento social e econômico para as populações, devido a sua malha hídrica com imenso potencial pesqueiro, além da enorme diversidade de espécies de peixes esportivos, em especial, grandes tucunarés Açú.

Thomé-Souza et al. (2014) em trabalhos realizados na bacia do Rio Negro, o maior afluente do Rio Amazonas, estimaram taxas de mortalidade de tucunaré muito baixas para três 
espécies, sendo Cichla temensis Humboldt, com 3,5\%; Cichla orinocensis Humboldt, com 2,3\% e Cichla monoculus Agassiz com 5,2\% de mortalidade.

Pioneiro na atividade de pesca amadora na modalidade pesque-e-solte, o Lodge de Pesca da Ecotur Turismo começou as operações em seu empreendimento em 1990, sendo o único que operava na região do baixo Rio Branco (CADERNO NOVA CARTOGRAFIA, 2014, p.4). Essa atividade iniciou-se devido à presença de grandes exemplares de tucunaré e a extensão da rede hidrográfica (FREITAS e RIVAS, 2006). Tornando-se um atrativo para pescadores esportivos de outras regiões do país e do exterior (VITÓRIO, 2014). Em Roraima, a imagem do município de Caracaraí como paraíso da pesca esportiva tem sido vendida nas agências de turismo e nos sites de pesca esportiva (CADERNO NOVA CARTOGRAFIA, 2014). De fato, no município de Caracaraí as pescarias recreativas são especializadas, as taxas de liberação voluntária se aproximam de 100\% dos peixes capturados durante a temporada de pesca esportiva. Na jurisdição do Rio Água Boa do Univini, existem regulamentos que determinam a captura e liberação da pesca, essa política é uma tentativa de conservar os recursos pesqueiros da micro-bacia. A captura e liberação beneficia a pesca em muitas situações diferentes.

\subsection{CAPACIDADE DE CARGA}

\subsubsection{Histórico}

Segundo Siles (2003) a ideia de capacidade de carga tem sua origem nas ciências agrárias, na década de 1930, nos Estados Unidos, especificamente no manejo das pastagens como uso recreativo. Porém, a primeira referência do uso de capacidade de carga no turismo, foi com J. Alan Hagar em sua publicação em 1964, intitulada The Carrying Capacity of Wild Lands for Recreation, ou seja, como "o nível de uso que uma área pode suportar sem afetar a sua qualidade", aplicado em trabalhos de manejo de visitantes em parques e reservas naturais protegidas. A aplicação do conceito teve seu interesse aumentado a partir da década de 1970, como uma técnica para gestão do turismo em áreas sensíveis (PIRES, 2005), observando que nessa mesma época iniciaram-se, de forma mais contundente, os estudos referentes aos impactos causados pela atividade turística de massa em ambientes naturais e artificiais.

De acordo com Hagar (1964), o homem, desde os tempos pré-históricos, tem enfrentado a capacidade de carga limitada da terra. No Antigo Testamento e outros escritos 
antigos contêm muitas referências à limitação da terra, geralmente o problema tem sido por escassez de alimento e de água.

Em 1956, por ocasião do quinquagésimo aniversário do Serviço Nacional de Parques, foi lançanda a Missão 66, para atender tanto às demandas imediatas quanto às previstas para o ano de 1966, sujeito às mesmas pressões recreativas. No ano de 1957 o Serviço Florestal Americano iniciou a Operação Exterior para atender aos visitantes esperados em 1962. As visitas excederam as previsões em mais de 15 milhões, acima dos 66 milhões de visitas previstas para o ano de 1962 (HAGAR, 1964, grifo nosso).

Hagar (1962, p. 2, tradução nossa) comenta que:

Desde 1956, um projeto de lei para fornecer um sistema deserto foi introduzido em cada congresso; e em 1958 o Congresso autorizou a Comissão de Revisão de Recursos de Recreio Exterior. As mesmas perguntas se repetem: quanta terra é suficiente? Qual é a capacidade de carga dessas terras selvagens? A recreação em terra silvestre deve agora ser administrada em uma base de rendimento sustentado? Os gestores de recursos já estão acostumados a pensar em manejo de produção sustentada em termos como colheitas permitidas de madeira e números permitidos de gado em pastagens.

Estudos desses limites permitidos mostraram-se úteis, e os mesmos padrões de pensamento foram aplicados à recreação. Assim, nos últimos anos, a capacidade de suporte de terras selvagens para recreação foi identificada como uma área que necessita de estudo (WAGAR, 1964).

\subsubsection{Conceito}

De acordo com Hagar (1964); Cordeiro, Körössy e Selva (2013), entende-se que o conceito de capacidade de carga é o nível de uso recreativo que toda área possui a um limite tolerável, que suporta uma quantidade de usuários que a mesma pode acomodar, sem que impactos significativos sejam gerados no ambiente visitado, fornecendo uma qualidade sustentada de recreação.

Em 1974, Alan Wagar fez algumas considerações na sua definição, admitindo que a experiência recreativa é, antes de tudo, psicológica. A capacidade de carga passou, assim, a 
ser expressa como sendo o nível de uso recreativo que uma dada área pode suportar ao mesmo tempo em que proporciona uma qualidade de experiência recreativa sustentável.

Siles (2003) observa que nessa definição estão implícitos, pelo menos, dois componentes: (i) um referente à capacidade de carga biológica ou biofísica (Kb); (ii) e outro referente à capacidade de carga social (Ks).

Siles (2003, p.38) enfatiza que

O conceito de experiência recreativa satisfatória apresenta uma grande limitação para sua aplicação, devido à capacidade de adaptação do homem: a Ks é variável e maior do que a $\mathrm{Kb}$, ou seja, para uma mesma área e um mesmo tipo de impacto, diferentes usuários têm diferentes opiniões.

Cordeiro, Körössy e Selva (2013) relatam que

\begin{abstract}
Pesquisadores como Cifuentes et al (1992) através de suas constantes observações, viriam a corroborar a ideia de que considerar apenas parâmetros biológicos e físicos não seria suficiente. Caso não houvesse a inclusão de fatores que levassem em conta a qualidade da experiência da visitação, os estudos de capacidade de carga seriam de pouca serventia para o planejamento de locais de interesse recreativo. A partir daí, as pesquisas sobre capacidade de suporte abarcariam novas preocupações e passariam a se interessar não somente pelos aspectos naturais, mas também pela satisfação dos anseios do visitante.
\end{abstract}

Segundo Mitraud (2003, apud SIOLI, 2005, p. 227, grifo do autor), a capacidade de carga foi desenvolvida com o propósito de gerar um indicador quantitativo, uma espécie de "termômetro" para os gestores de áreas onde nunca se fez o acompanhamento sistemático dos impactos de visitação. Os gestores do atrativo turístico natural devem manter o número de visitantes em uma área protegida abaixo da capacidade da carga estabelecida. Entretanto, o número não é definitivo, cujo cumprimento absoluto resolve e previne todo e qualquer impacto inaceitável. Diversas vezes o tipo de uso e o comportamento do visitante são fatores que oferecem um risco muito mais elevado do que a quantidade de visitantes.

De acordo do Cooper et al. (2001, apud SIOLI, 2005, p. 227), o planejamento ambiental do atrativo turístico natural envolve a capacidade de carga como instrumento de determinação do quantitativo de visitação, monitoramento e gestão dos impactos de visitação turística, sendo indispensável um programa de visitação sério.

Ruschmann (1999) também ressalta que a capacidade de carga recreativa deve ser parte integrante do planejamento turístico das áreas dos referidos empreendimentos, como atrativos principais desses recursos naturais. De acordo com Melo et al. (2006) a capacidade de carga recreativa em ambientes de águas interiores leva em considerações os fatores como o nível de gerenciamento do empreendimento, a observância às leis, a conscientização 
ambiental e o comportamento dos pescadores esportivos e de outros usuários desse recurso como determinantes para a produção dos impactos nessa área. É, pois, diante deste cenário, que se entende ser necessário o disciplinamento do uso turístico desta área. Neste sentido, considera-se que a estipulação de um limite máximo de embarcações que pode estar presente na área é uma ação importante e que não pode, portanto, ser negligenciada.

Para determinar este limite máximo de embarcações na pesca esportiva no Rio Água Boa do Univini, na região do baixo Rio Branco, em Roraima, recorreu-se à metodologia elaborada por Cifuentes et al. (1992), sendo essa metodologia adaptada para as condições aquáticas do Rio Água Boa do Univini.

\subsection{UNIDADE DE CONSERVAÇÃO}

O Sistema Nacional de Unidades de Conservação (SNUC) define e regulamenta as categorias de unidades de conservação em dois grupos: de proteção integral, com a conservação da biodiversidade como principal objetivo, e áreas de uso sustentável, que permitem várias formas de utilização dos recursos naturais, com a proteção da biodiversidade como um objetivo secundário (MMA-SNUC, 2000).

Segundo a Lei No 9.985, de 18 de julho de 2000, Unidade de Conservação (UC) é o espaço territorial e seus recursos ambientais, incluindo as águas jurisdicionais, com características naturais relevantes, legalmente instituído pelo Poder Público, com objetivos de conservação e limites definidos, sob regime especial de administração, ao qual se aplicam garantias adequadas de proteção.

Esses espaços são separados em algumas porções do território e limitados o uso da terra e de ocupação, bem como a utilização de seus recursos. Para Craveiro (2008), essas áreas protegidas não são mais vistas como áreas para o impedimento do desenvolvimento, mas sim, para a manutenção de espécies da fauna e flora, para melhorar o ciclo das águas e seu regime de chuvas, evitar processos erosivos e assoreamento de rios, educação ambiental, bem como outros aspectos que influenciam na qualidade de vida dos seres humanos.

Ainda de acordo com Craveiro (2008), as áreas protegidas são vitais para a conservação dos recursos naturais, e têm como função a preservação de amostras representativas de uma determinada região com suas diversidades biológicas, até a manutenção da estabilidade ecológica das zonas que as circundam. 
Segundo Bensusan (2006), dois motivos levaram à criação de espaços preservados: i) a preservação de lugares sagrados e ii) a manutenção de estoques de recursos naturais.

\subsubsection{Sistema Nacional de Unidade de Conservação da Natureza}

Craveiro (2008) afirma que vários países têm instituído sistemas nacionais de unidades de conservação, com propósito regulatório para as áreas naturais protegidas, dispondo sobre os objetivos nacionais de conservação, conceituação das diferentes categorias de manejo, normatização do zoneamento, manejo e peculiaridades a respeito de cada tipo de unidade, buscando, dessa forma, otimizar a eficácia nas intervenções antrópicas no meio natural.

A Lei $N^{\circ}$. 9.985, de 18 de julho de 2000, denominada de Lei do SNUC, objetiva auxiliar o ordenamento das inúmeras leis dispostas sobre as diversas categorias de manejo, assim como também definir critérios e normas federais, estaduais ou municipais para o estabelecimento e gestão das áreas protegidas em todo o território nacional. Essa Lei, em seu art. $3^{\circ}$ apresenta o conjunto das unidades de conservação federais, estaduais e municipais.

Por outro lado em seu art. $4^{\circ}$ tem os seguintes objetivos:

\footnotetext{
(...)

I - contribuir para a manutenção da diversidade biológica e dos recursos genéticos no território nacional e nas águas jurisdicionais;

II - proteger as espécies ameaçadas de extinção no âmbito regional e nacional;

III - contribuir para a preservação e a restauração da diversidade de ecossistemas naturais;

IV - promover o desenvolvimento sustentável a partir dos recursos naturais;

V - promover a utilização dos princípios e práticas de conservação da natureza no processo de desenvolvimento;

VI - proteger paisagens naturais e pouco alteradas de notável beleza cênica;

VII - proteger as características relevantes de natureza geológica, geomorfológica, espeleológica, arqueológica, paleontológica e cultural;

VIII - proteger e recuperar recursos hídricos e edáficos;

IX - recuperar ou restaurar ecossistemas degradados;

$\mathrm{X}$ - proporcionar meios e incentivos para atividades de pesquisa científica, estudos e monitoramento ambiental;

XI - valorizar econômica e socialmente a diversidade biológica;

XII - favorecer condições e promover a educação e interpretação ambiental, a recreação em contato com a natureza e o turismo ecológico;

XIII - proteger os recursos naturais necessários à subsistência de populações tradicionais, respeitando e valorizando seu conhecimento e sua cultura e promovendo-as social e economicamente.
}

Ainda segundo Craveiro (2008), as Unidades de Conservação podem ser divididos em dois grupos: Unidades de Proteção Integral e Unidades de Uso Sustentável. 
As Unidades de Conservação mostrados por meio da figura 1, presentes na área de estudo são de Proteção Integral. Têm como objetivo principal preservar a natureza, sendo admitido apenas o uso indireto dos seus recursos naturais para fins de atividades educacionais, científicas e recreativas. Podendo ser dividido esse grupo nas seguintes categorias: Estação Ecológica (ESEC), Reserva Biológica (REBIO), Parque Nacional (PARNA), Monumento Natural e Refúgio da Vida Silvestre (CRAVEIRO (2008). Na região estudada há ocorrência de duas unidades de conservação: a Estação Ecológica do Niquiá (ESEC Niquiá) e o Parque Nacional Serra da Mocidade (PARNA Serra da Mocidade), destaca-se a não existência de comunidades ribeirinhas, e em conformidade com a lei, suas principais características são:

Estação Ecológica: A Lei 6.902, de 27 de abril de 1981, já trazia disposições sobre a criação de Estações Ecológicas e Áreas de Proteção Ambiental, definindo dessa maneira:

\begin{abstract}
Estações Ecológicas são áreas representativas de ecossistemas brasileiros, destinadas à realização de pesquisas básicas e aplicadas a Ecologia, à proteção do ambiente natural e ao desenvolvimento da educação conservacionista. (...) serão implantadas e estruturadas de modo a permitir estudos comparativos com as áreas da mesma região ocupadas e modificadas pelo homem, a fim de obter informações úteis ao planejamento regional e ao uso racional de recursos naturais (MEDAUAR, 2006, p. 505).
\end{abstract}

Previsto no art. $9^{\circ}$, da Lei 9.985/2000, o Sistema Nacional de Unidades de Conservação da Natureza - SNUC, as Estações Ecológicas, ou ESEC, tem como objetivo a Preservação da Natureza e a realização de pesquisas científicas. É de posse e domínio público (áreas particulares em seus limites serão desapropriadas, conforme a lei). A visitação pública é proibida, com exceção quando for com o objetivo educacional e se dispuser no Plano de Manejo. As pesquisas científicas dependerão de autorização prévia do órgão responsável pela administração da unidade.

As estações só poderão ser criadas pela União, Estados e Municípios, em terras de seus domínios, definindo em sua criação seus limites geográficos e o órgão responsável pela sua administração.

O DECRETO N 91.306, de 3 DE JUNHO de 1985 cria a Estação Ecológica Niquiá em área de terra que indica, e dá outras providências.

Decreta no art. $1^{\mathrm{o}}$ :

Fica criada a Estação Ecológica Niquiá em terras da União, situadas no Município de Caracaraí, no Território de Roraima, com uma área aproximada de 286.600 ha (duzentos e oitenta e seis mil e seiscentos hectares), com as seguintes características e confrontações: Inicia-se o perímetro da área do P1 de coordenadas geográficas 
aproximadas Longitude $61^{\circ} 15^{\prime} 05^{\prime \prime}$ WGr e Latitude $01^{\circ} 32^{\prime} 40^{\prime \prime} \mathrm{N}$, localizado na confluência do rio Ajaraní com o rio Branco; e deste pela margem direita do rio Branco no sentido jusante a uma distância aproximada de $47.000 \mathrm{~m}$ (quarenta e sete mil metros), chega-se ao P2 de coordenadas geográficas aproximadas Longitude 61²0'27" WGr e Latitude 0109'15" N, localizado na foz de um igarapé sem denominação, afluente da mesma margem do referido Rio; daí segue-se o referido igarapé pela margem esquerda no sentido montante a uma distância aproximada de $18.500 \mathrm{~m}$ (dezoito mil e quinhentos metros), onde encontra-se o P3 de coordenadas

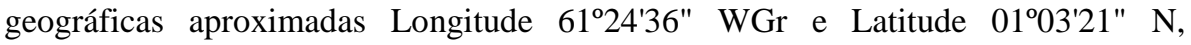
localizado em um dos formadores d'água de referido igarapé, deste ponto o segue-se por uma linha reta no rumo de $44^{\circ} 10^{\prime} 42^{\prime \prime} \mathrm{SW}$, a uma distância aproximada de 14.000 m (quatorze mil metros) encontra-se o P4 de coordenadas geográficas aproximadas

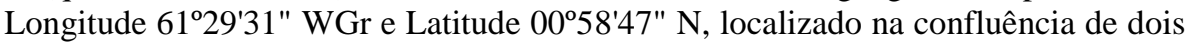
formadores d'água do igarapé Niquiá; deste ponto segue-se o Igarapé pela margem direita no sentido jusante a uma distância aproximada de $30.000 \mathrm{~m}$ (trinta mil metros), chega-se ao P5 de coordenadas geográficas aproximadas Longitude $61^{\circ} 38^{\prime} 19^{\prime \prime}$ WGr e Latitude $00^{\circ} 47^{\prime} 18^{\prime \prime} \mathrm{N}$, localizado na foz do referido igarapé no rio Água Boa do Univini; daí segue-se o referido Rio pela sua margem esquerda no sentido montante a uma distância aproximada de $112.000 \mathrm{~m}$ (cento e doze mil metros), encontra-se o P6 de coordenadas geográficas aproximadas Longitude 61⒊'12" WGr e Latitude $01^{\circ} 27^{\prime} 55^{\prime \prime} \mathrm{N}$, localizado na foz de um igarapé sem denominação afluente da mesma margem do referido Rio, e deste pela margem esquerda do referido igarapé no sentido da montante a uma distância aproximada de $20.000 \mathrm{~m}$ (vinte mil metros), encontra-se o P7 de coordenadas geográficas

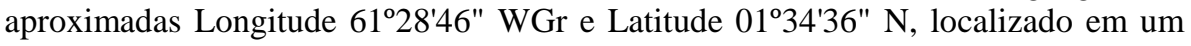
dos formadores d'água do mesmo igarapé; e deste por uma linha reta no rumo de 12³6'31" NE, a uma distância aproximada de $19.600 \mathrm{~m}$ (dezenove mil e seiscentos metros), chega-se ao P8 de coordenadas geográficas aproximadas Longitude $61^{\circ} 26^{\prime} 08^{\prime \prime}$ WGr e Latitude 01\% $45^{\prime} 00^{\prime \prime} \mathrm{N}$, localizado na foz de um igarapé sem denominação afluente da margem direita do rio Ajaraní; daí, segue-se o referido Rio pela margem direita no sentido da jusante a uma distância aproximada de $54.000 \mathrm{~m}$ (cinqüenta e quatro mil metros), chega-se ao P1, ponto inicial da descrição deste perímetro.

Parque Nacional: Conforme o art. $11^{\circ}$ do SNUC, os PARNAs têm como objetivo básico:

(...) a preservação de ecossistemas naturais de grande relevância ecológica e beleza cênica, possibilitando a realização de pesquisas científicas e o desenvolvimento de atividades de educação e interpretação ambiental, de recreação em contato com a natureza e de turismo ecológico (MEDAUAR, 2006, p. 1041).

São de posse e domínio públicos, e a visitação pública está sujeita às normas e restrições estabelecidas no Plano de Manejo da Unidade, sendo estas estabelecidas pelo órgão responsável por sua administração. A pesquisa científica depende da autorização prévia do órgão responsável pela unidade.

As unidades dessa categoria, quando criadas pelos Estados ou Municípios, serão denominadas, respectivamente, Parque Estadual e Parque Natural Municipal.

O DECRETO de 29 de ABRIL DE 1998 cria o Parque Nacional Serra da Mocidade, no Estado de Roraima, e dá outras providências.

Decreta no art. $2^{\circ}$ : 
O Parque Nacional Serra da Mocidade localiza-se no Município de Caracaraí, Estado de Roraima, com perímetro de quatrocentos e quarenta e três mil, oitocentos e oitenta metros, apresentando os limites a seguir descritos: torna-se como origem o marco IV-1, de coordenadas planas $\mathrm{N}=158.350,00$ e $\mathrm{E}=653,770,00$ no fuso de meridiano central $63^{\circ} \mathrm{W}$, localizado na margem direita do rio Água Boa do Univini, no encontro deste com um igarapé sem denominação; deste, segue pela margem direita do citado rio, num percurso aproximado de setenta e nove mil metros, sentido jusante, até o marco IV-2, de coordenadas planas N=117.730,00 e E=639.920,00, situado na margem direita do dito rio, em sua confluência com o rio Capivara; deste, segue por uma linha seca, limite com terras de jurisdição estadual, até o marco IV-3, de coordenadas planas $\mathrm{N}=70.830,00$ e $\mathrm{E}=553.830,00$, situado na linha limite interestadual do Amazonas e Roraima; deste, segue por uma linha seca, acompanhando a linha limite interestadual anteriormente citada, até o marco IV-4, de coordenadas planas $\mathrm{N}=110.475,00$ e $\mathrm{E}=554$ 825,00, situado no limite interestadual supracitado, comum para as terras indígenas Yanomani e terras arrecadadas pela União; deste, segue por uma linha seca, limite com terras arrecadadas pela União, até o marco IV-5, de coordenadas planas $\mathrm{N}=110.560,00 \mathrm{e}$ $\mathrm{E}=611.260,00$; deste, segue por urna linha seca, limite com terras arrecadadas pela União, até o marco IV-6, de coordenadas planas N=164.600,00 e E=611.230,00, comum para as terras da área indígena Yanomani e terras arrecadadas pela União; deste, segue por urna linha seca, limite com terras indígenas Yanomani, até o marco IV-7, de coordenadas planas $\mathrm{N}=164.590,00$ e $\mathrm{E}=611.560,00$, localizado na cabeceira de um igarapé sem denominação, na Serra da Mocidade, comum para as terras indígenas citadas; deste, segue pelo igarapé sem denominação, sentido jusante, limite com terras indígenas Yanomani, até o marco IV-8, de coordenadas planas $\mathrm{N}=173.500,00$ e $\mathrm{E}=619.280,00$, localizado na confluência do mesmo com o rio Pacu, comum para as terras indígenas Yanomani; deste, segue pelo rio Pacu, sentido montante, limite com terras indígenas Yanomani, até o marco IV-9, de coordenadas planas $\mathrm{N}=180.570,00$ e $\mathrm{E}=622.365,00$, localizado na confluência do rio Pacu com igarapé sem denominação, comum para as terras indígenas Yanomani; deste, segue por uma linha seca, até o marco IV-10, de coordenadas planas N=187.940,00 e $\mathrm{E}=627.610,00$, situado no rio Ajarani, em sua confluência com um igarapé sem denominação; deste, segue pelo rio Pacu, sentido montante, limite com terras indígenas Yanomani, até o marco IV-11, de coordenadas planas N=189.890,00 e $\mathrm{E}=632.050,00$, situado na confluência do rio Pacu com um igarapé sem denominação, comum para as terras indígenas citadas e para terras arrecadadas pela União; deste, segue por uma linha seca, limite com terras arrecadadas pela União, até o marco IV-12, de coordenadas planas $\mathrm{N}=172.310,00$ e $\mathrm{E}=641.260,00$, situado na confluência de dois igarapés sem denominação, comum para terras arrecadadas pela União; deste, segue pelo igarapé principal, limite natural com terras arrecadadas pela União, até o marco IV-1, início da descrição deste polígono, que encerra uma área de aproximadamente trezentos e cinqüenta mil, novecentos e sessenta hectares, e quatro mil, quinhentos e vinte centiares. 
Figura 1 Unidades de Conservação presentes na área de estudo.

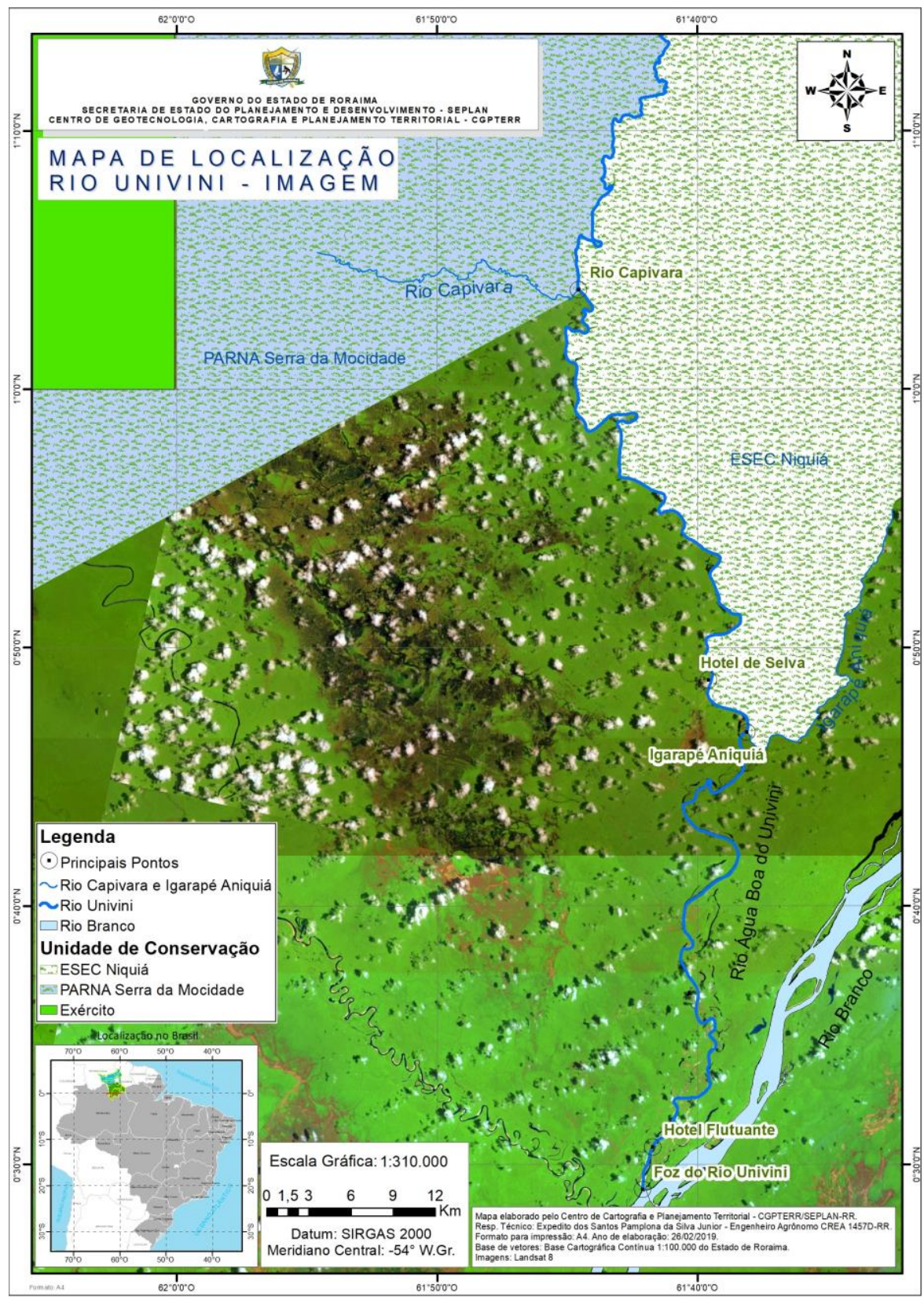

Fonte: SEPLAN, 2019.

As Unidades de Conservação têm um papel fundamental para a conservação dos recursos naturais dos espaços protegidos e suas funções no sentido de preservar amostras representativas de regiões naturais e de sua diversidade biológica, a manutenção da estabilidade ecológica, os valores culturais de uma população circunvizinha. Neste panorama, a pesca esportiva desponta como uma grande opção pra servir como atrativo ao turista que aprecia a natureza conservada. 


\subsection{ESTOQUE PESQUEIRO}

Para Catella (2004), o estoque pesqueiro como sendo uma população agregada que pode ser manejada como unidade discreta, e seu rendimento de produção são o peso total dos peixes capturados. As pescarias são seletivas e agem em uma porção específica do estoque, sendo considerado o estoque explorável, definido por Ricker (1975, apud CATELLA, 2005, p. 12) como o peso de todos os peixes do estoque, maiores que o tamanho de primeira captura. O estoque explorável apresenta dois componentes de perda de indivíduos: i) um por mortalidade natural, tais como: predação, parasitismo, acidentes, mutilações e etc. e, ii) com a pesca, essa captura efetuada pelo homem, o que resulta em perda de biomassa.

O repovoamento do estoque pesqueiro é provavelmente a ferramenta de gerenciamento mais difundida e utilizada pelas empresas de pescas amadoras empregadas atualmente nas pescarias de água doce. A maioria dos países efetua programas de repovoamento ou estocagem de peixes de água doce à medida que abordagens mais convencionais de gestão não conseguem controlar a exploração de pescados ou a redução da biomassa por meio da degradação ambiental, ou em tentativas de aumentar o rendimento da pesca (ARLINGHAUS et al., 2009).

Arlinghaus et al. (2009) descrevem que as atividades de manejo pesqueiro utilizadas nas pescarias de água doce associadas à manutenção do desempenho da pesca recreativa, especialmente o aumento de estoque, também são responsáveis pela mudança na estrutura trófica. $\mathrm{O}$ armazenamento e as introduções de peixes alteraram a estrutura trófica de muitas comunidades de peixes em todo o mundo, muitas vezes aumentando o nível trófico através da introdução de espécies predatórias direcionadas ou enfatizando um nível trófico reservado.

Mérona (1995, p. 176-177, grifo do autor) ressalta que

Todos os ambientes são extremamente variáveis sazonalmente e os pescadores aproveitam desta variabilidade. O funcionamento da maioria dos ambientes de água doce na Amazônia é regulado pelo regime de enchentes, particularmente acusado em toda extensão da bacia. Para planícies de inundação Junk et al. (1989) desenvolveram o flood pulse concept que postula que a pulsação anual do fluxo d'água constitui-se no fator principal controlando o compartimento biológico neste ambientes. Os ciclos biológicos dos peixes são estreitamente dependentes dos eventos hidrológicos. A reprodução da maioria das espécies ocorre na época da subida das águas. Esta estratégia permite uma otimização da sobrevivência e do crescimento dos juvenis que colonizam os ambientes marginais recém inundados, ricos em nutrientes e relativamente protegidos dos predadores. Esses fenômenos sazonais são extremamente variáveis de um ano para outro. É essa variabilidade que ultimamente controla as flutuações na abundância das populações de peixes que constituem a preocupação central da gestão das pescarias. 
Barthem et al. (1997, p.180) enfatiza que

As estratégias adotadas para o manejo de estoques pesqueiros podem ser resumidos
em: não fazer nada ou adotar uma ou mais de uma série de medidas restritiva à
pesca. A opção "não fazer nada" é frequentemente adotada quando os responsáveis
pela administração pesqueira não assumem qualquer medida de manejo para os
estoques já explorados comercialmente. Isto ocorre quando: há uma decisão
administrativa em não se manejar o estoque, por se julgar desnecessária tal medida;
não há conhecimento suficiente sobre a ecologia e a pesca desses estoques; ou,
quando não há recursos destinados à execução do manejo. Quando os
administradores pesqueiros se empenham em elaborar e executar estratégias para o
manejo de um ou mais estoques pesqueiros, geralmente adotam uma ou mais das
seguintes opções: a) Limitar acesso às áreas pesqueiras (zoneamento); b) Restringir
o uso de determinados aparelhos de pesca; c) Controlar ou limitar o tamanho da
malha das redes de pescas; d) Proibir a pesca em estações definidas (defeso); e)
Controlar o esforço de pesca através de cotas e licenças para barcos de pesca; e f)
Criar reservas em que se proíba a pesca ou esta seja limitada à pesca de subsistência.

Os recursos pesqueiros são recursos naturais renováveis e podem ser utilizados sem prejuízos ambientais, respeitando-se a capacidade de reposição dos estoques. Segundo Sparre e Venema (1997), a avaliação de mananciais pesqueiros é fundamental para fornecer recomendações para a exploração eficaz desses recursos. Entretanto, esses recursos são limitados, e a avaliação de mananciais proporciona nível de exploração que, a longo prazo, produza o máximo de captura em peso. Segundo Catella (2004), os princípios fundamentais da teoria pesqueira têm uma relação que pode ser repetida entre a aplicação do esforço de pesca e a captura média obtida. A produção, em peso, tem seu crescimento com o aumento do esforço de pesca até certo ponto, a partir do qual, essa produção diminui, mesmo com o aumento da intensidade do esforço de pesca, conforme figura 2. 
Figura 2 - Captura em relação ao esforço de pesca.

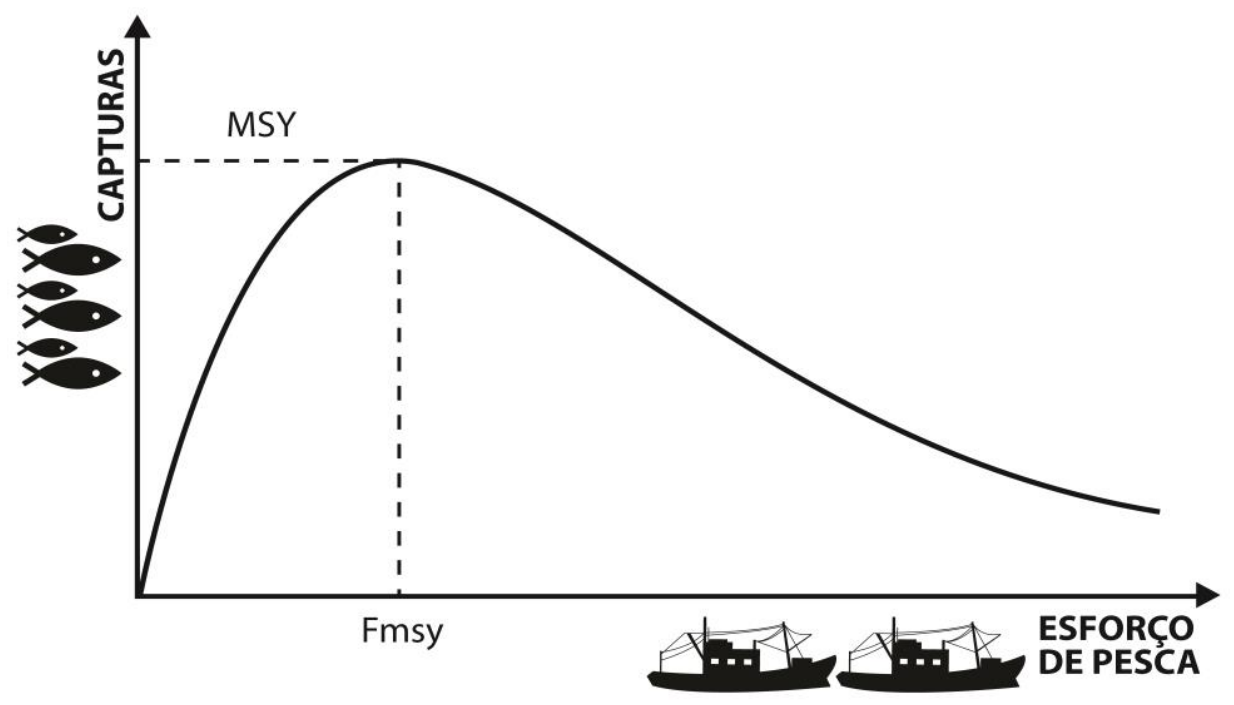

Fonte: Adaptado de Sparre, P; Venema, S.C. 1997.

Cooke e Cowx (2004) atribuíram a pesca comercial como um fator causal importante para o declínio global dos estoques de peixes. Recentemente esses autores estimaram que as pescarias recreativas apresentam um grande potencial para o declínio da pesca, onde a captura de peixes recreativos em todo o mundo pode representar aproximadamente $12 \%$ da produção mundial de peixes. Ainda segundos os autores, as pescarias recreativas têm acesso à maioria dos sistemas de água doce do mundo, bem como às regiões costeiras dos oceanos, incluindo estuários, recifes e manguezais. As zonas costeiras, alvo da pesca recreativa, são frequentemente habitats críticos para vários estágios da vida de muitos peixes tais como desova, viveiro, alimentação e migração, e os pescadores recreativos frequentemente visam fases de vida imaturas nestas regiões.

Nos últimos anos, as pescas comerciais têm sido repetidamente identificadas como os principais agentes causais no declínio global das unidades populacionais de peixes (BOTSFORD et al., 1997; SMITH, 2002; CHRISTENSEN et al., 2003; HILBORN et al., 2003; PAULY et al., 2003, apud COOKE, COWX, 2004, p. 93). 
Segundo a EMBRAPA PANTANAL (2011), o rendimento da pesca depende da reposição natural dos estoques e da disponibilidade de peixes no ambiente. Isto, por sua vez, depende das decisões de manejo da pesca e, sobretudo, de fatores externos, que podem ser de origem natural ou antrópica. Os fatores naturais geralmente são cíclicos, sendo o principal no Pantanal a intensidade das inundações anuais. Os fatores antrópicos muitas vezes são irreversíveis (ou dificilmente reversíveis) e implicam alterações na qualidade do ambiente ou na manutenção dos processos ecológicos.

Enfim, este trabalho de pesquisa visa contribuir para a discussão sobre a capacidade de carga de pesca esportiva embarcada praticada no Rio Água Boa do Univini, na região do baixo Rio Branco, como modelo de gestão em relação à pesca esportiva praticada em embarcações para aplicação neste rio da Amazônia. É interessante ressaltar que poucas publicações relacionadas a este assunto foram encontradas e, por isso, reforça-se o caráter inovador deste estudo.

\section{OBJETIVOS}

De acordo com Goode (1979), é fundamental que haja a definição clara dos objetivos do estudo, e estes devem ser completamente interligados e restritos à solução do problema de pesquisa.

Os objetivos propostos para este estudo são agrupados em objetivo geral e específicos, e estão expostos a seguir, delimitando o processo do estudo a ser realizado.

\subsection{OBJETIVO GERAL}

Avaliar a sustentabilidade da pesca esportiva praticada em embarcações em uma micro bacia da Amazônia, a partir da capacidade de carga do número de pescadores esportivos envolvidos, do número de modalidades de pesca e considerando a existência de uma unidade de conservação como fonte de reposição para os estoques da espécie alvo.

\subsection{OBJETIVOS ESPECÍFICOS}

a) determinar a intensidade de pesca atual (capacidade de carga) da pesca esportiva; 
b) estimar indicadores de impactos sociais e ecológicos que melhor representem a sustentabilidade ambiental da área em estudo;

c) adaptar um método de estimação da capacidade de carga de visitante (pescador esportivo) para os rios da Amazônia;

d) estimar a capacidade de suporte de carga de pesca esportiva (intensidade de pesca sustentável), que utilizam a pesca embarcada no Rio Água Boa do Univini na região do baixo Rio Branco;

e) comparar a estimativa de pesca esportiva vigente com a intensidade de pesca sustentável estimada para o Rio Água Boa do Univini na região do baixo Rio Branco;

f) verificar a correlação entre as condições desejadas dos respectivos lagos do Rio Água Boa do Univini pelos pescadores esportivos e aquelas existentes;

g) avaliar a importância de unidades de conservação na micro bacia como fonte de reposição dos estoques;

h) propor estratégias de manejo sustentável da atividade de pesca esportiva considerando a intensidade sustentável e o desenvolvimento concorrente de outras modalidades de pesca.

\section{MATERIAIS E MÉTODOS}

Segundo Lakatos (2003), método é o conjunto das atividades sistemáticas e racionais que, com maior segurança e economia, permite alcançar o objetivo, a partir de conhecimentos válidos e verdadeiros, traçando o caminho a ser seguido, detectando erros e auxiliando as decisões do pesquisador.

\section{1 ÁREA DE ESTUDO}

O presente estudo foi realizado no Rio Água Boa do Univini, afluente da margem direita do Rio Branco. O Rio Água Boa do Univini está localizado no município de Caracaraí, situado no sul do Estado de Roraima. Caracaraí é o terceiro município mais populoso do estado, com 21.564 habitantes (IBGE, 2017). É conhecida como Cidade-Porto, por ter o maior movimento fluvial do estado. Caracaraí é o maior município de Roraima em área territorial, situado na região centro-sul do estado e atravessando-o de leste a oeste, apresenta 
extensão territorial de $47.411 \mathrm{~km}^{2}$, com uma densidade demográfica de $0,39 \mathrm{hab} / \mathrm{km}^{2}$ (IBGE, 2017). Localiza-se a uma distância de 122, $35 \mathrm{~km}$ em linha reta e $141 \mathrm{~km}$ por estrada de Caracaraí a Boa Vista, capital do Estado de Roraima. O clima, segundo a Classificação Climática de Köppen-Geiger, é do tipo tropical chuvoso, com os totais anuais de precipitação pluviométrica relativamente elevados, chegando a 2.000 milímetros.

O acesso é realizado por via fluvial, partindo-se de Caracaraí com destino ao Rio Água Boa do Univini. O trajeto é realizado em 3 horas em lancha rápida com motor de $250 \mathrm{HP}$ e 12 a 14 horas em barcos regionais de linha, ou ainda, através de hidroaviões até a Plataforma flutuante da Porto Tur - Pesca Esportiva e aviões tipo Caravan que podem utilizar a pista de pouso do Água Boa Amazon Lodge (informação verbal) ${ }^{1}$.

Nas bacias dos rios Água Boa do Univini e Ajarani está inserida a Estação Ecológica do Niquiá, enquanto afluentes da margem direita, como o rio Capivara, estão inseridos no Parque Nacional Serra da Mocidade (Figura 3). A ESEC Niquiá é uma unidade de conservação com uma área de 306.394,55 hectares, com feições de Campina Arbustiva e áreas de contato com a Floresta Ombrófila. O relevo é caracterizado por superfícies planas, localmente alagáveis nos períodos das chuvas, com setores permanecendo alagados por período de tempo prolongado e permanente. Por outro lado, o PARNA Serra da Mocidade possui uma extensão territorial de 376.812,61 hectares, com feições paisagísticas vinculadas ao tipo e à formação dos solos. O sistema hidrográfico é um intrincado emaranhado de fluxos de águas pretas e "mistas", variando a carga química e sedimentos, em função das chuvas e/ou enxurradas regionais. As diferentes tipologias de solo encontradas influenciam fortemente o tipo de vegetação. A distribuição das chuvas e o arranjo arquitetural da drenagem também acabam se tornando indutores de diversidade vegetal (e paisagística) pela forte influência na distribuição de espécies adaptadas àquelas condições de solo e química da água (BARBOSA, 2005).

O Água Boa Amazon Lodge e o Hotel Flutuante Porto Tur - Pesca Esportiva, operando no Rio Água Boa do Univini, foram utilizados como bases principais para o desenvolvimento do experimento científico, em função dos aspectos logísticos e técnicos. Foi utilizada a experiência dos guias de pescas esportivas para a prática da pesca experimental nas zonas estabelecidas com o objetivo de coletar as informações sobre a captura por unidade de esforço da espécie alvo, ver figura abaixo.

\footnotetext{
${ }^{1}$ Observação realizada pelo autor, durante a temporada de pesca esportiva de 2018/2019.
} 
Figura 3- Mapa de localização da área de estudo.

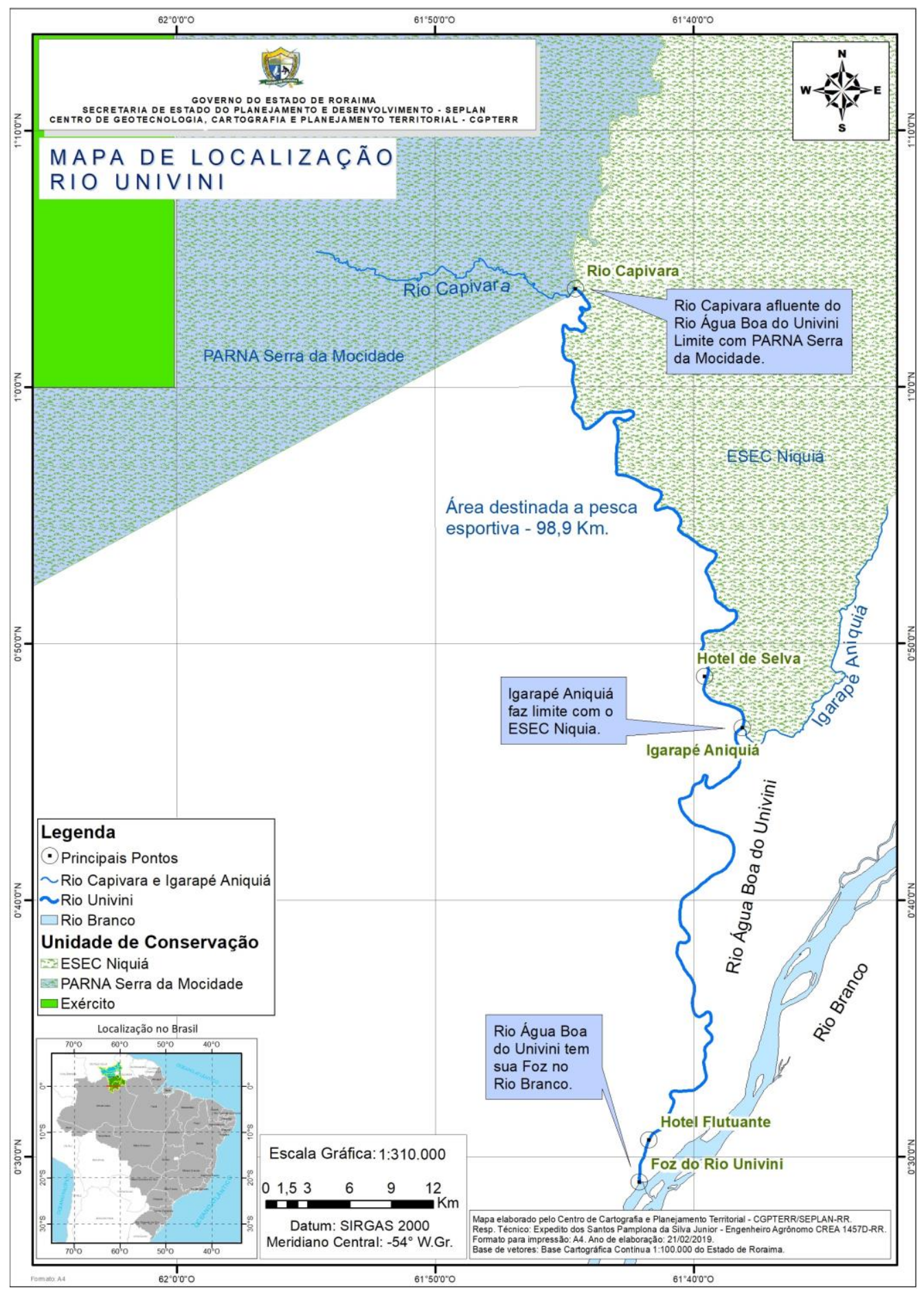

Fonte: SEPLAN, 2019. 


\title{
4.1.1 O Relevo e Solos
}

Para se ter conhecimento da paisagem de uma região, é necessário requerer a caracterização do relevo, vegetação, hidrografia, solo e clima. De acordo com Forman e Godron (1986, p. 48, grifo dos autores), o estudo da ecologia da paisagem tem três características essenciais: i) a estrutura, que está relacionada com as interações entre os elementos da paisagem em si e diferentes ecossistemas; ii) a função que são interações entre os elementos da paisagem e sua dinâmica constante de troca de energia, materiais e indivíduos entre os ecossistemas; e, iii) as mudanças, ocasionadas pelas alterações na estrutura e função do sistema ecológico da paisagem através da escala temporal.

Morais e Carvalho (2013, p. 50) relatam que

\begin{abstract}
Caracaraí apresenta uma diversidade de feições morfológicas do relevo, que contribuíram no estabelecimento de uma paisagem distinta e peculiar no domínio amazônico, formado por extensas planícies aluvionares, morfologicamente formada por paleocanais, planícies ativas meandriformes. O relevo possui baixo gradiente, cotas entre 40 a 150 metros em $90 \%$ de sua área, com decaimento para o sistema fluvial do rio Negro, ao norte apresenta um relevo estruturado (forte controle estrutural) formando a Serra da Mocidade, complexo serrano (com estruturas isoladas) entre 250 a 1980 metros. Portanto, o município é formado por uma extensa superfície de aplainamento, consequência do alto estágio de erosão de rochas précambrianas do embasamento cristalino. Motivo de ser fonte de extensos pacotes arenosos (solo quartzarênico), retrabalhado continuamente por um sistema de drenagem arreico, com feições de dunas inativas ao sul da Serra da Mocidade, de possível origem fluvial e do manto de intemperismo, o qual foi retrabalhado pela ação do vento em períodos climáticos passados mais secos.
\end{abstract}

O uso e cobertura do solo influenciam na estrutura da paisagem. A partir da divisão das classes de uso e cobertura do solo, a classe mais fragmentada são as áreas de floresta e a menos fragmentada são as áreas de campinaranas. As florestas são as áreas mais extensas e, portanto, mais suscetíveis à fragmentação, pois se trata da classe dominante da paisagem de Caracaraí, e é nelas que ocorrem todos os processos que modificam a estrutura dessa paisagem. Enquanto as campinaranas, que possuem grau zero de fragmentação, são manchas abertas dentro do domínio florestal, pois são classes isoladas dentro da vegetação que a cerca, elas não representam a característica dominante do território, embora seja a mais importante dentro dos elementos que diferenciam a paisagem do município de outros locais.

Vale Júnior e Schaefer (2010) descrevem Latossolo Amarelo como sendo solos formados a partir de sedimentos pré-intemperizados, cauliníticos e pobres em óxidos de ferro, acumulados em bacia sedimentar rasa. Esses solos estão associados a climas onde a estação 
seca é longa e bem distinta, sendo caracterizado por períodos secos e chuvosos bem marcantes, com médias pluviométricas anuais em torno de $1.600 \mathrm{~mm}$, fortemente concentradas nos meses de abril a setembro. Enquanto os Neossolos Quartzarênicos Hidromórficos são muito intemperizados, quartzosos, onde quase toda a argila foi destruída por acidólise, como nas áreas de campinaranas no chamado Pantanal de Roraima, ou depósitos de areias retrabalhadas formando paleodunas que foram acumulados por fenômenos eólicos, no Sul de Roraima. São compostos por material mineral maduro, não possuindo horizonte $\mathrm{B}$, devido à textura arenosa, ocorrendo em relevo plano ou em relevo abaciado, ou ainda em relevo suave ondulado, sob vegetação de savana, campina, campinarana e florestas.

Ainda de acordo com Vale Júnior e Schaefer (2010), Gleissolos Háplicos são solos minerais, formados por sedimentos depositados ao longo de rios, igarapés e em áreas abaciadas, hidromórficas, resultantes da saturação em água na maior parte do ano, onde a água atinge a superfície por ascensão capilar. Já os Espadossolos são solos predominantes na paisagem de campinaranas, ocorrem de forma generalizada em todas as gradações fitofisionomias, tais como campinaranas florestadas e gramíneo-lenhosas.

Durante o período destinado à prática da pesca esportiva nos meses de outubro a março, o Rio Água Boa do Univini fica muito seco, aparecendo dunas parabólicas inativas, provavelmente originadas de antigos depósitos aluvionares dos terraços remodelados pelo vento no sentido nordeste a sudoeste, dificultando a navegação nesse rio. 
Figura 4 - Mapa de solos da área de estudo.

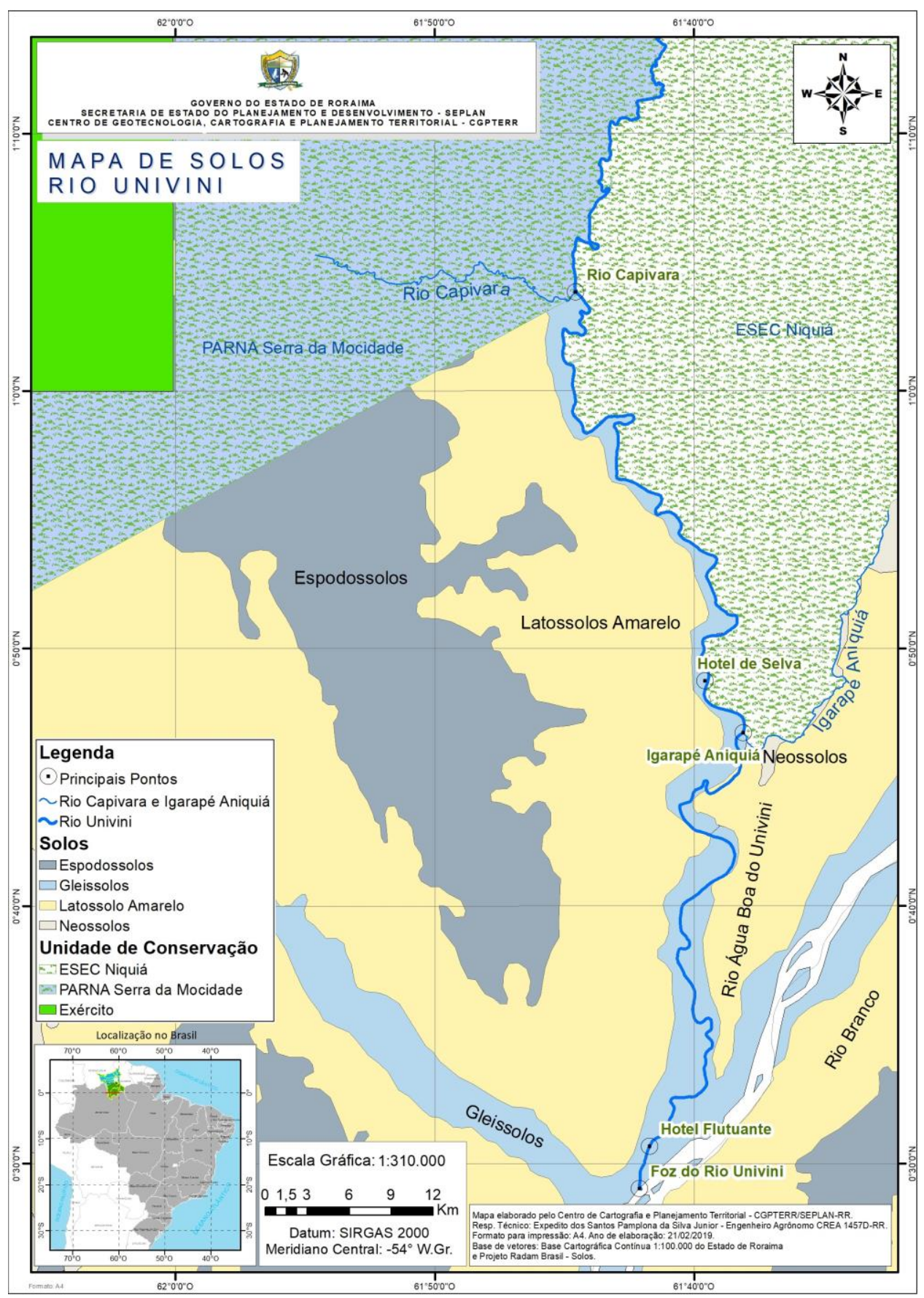

Fonte: SEPLAN, 2019.

\subsubsection{Vegetação}

Segundo Morais e Carvalho (2013), a cobertura vegetal é do tipo ombrófila densa e formações de campinaranas, áreas abertas em contato com sistema florestal, periodicamente 
encharcadas, sobre solo arenoso, entre meio a terraços aluvionares, com vegetação arbustiva e herbácea, onde estão inseridos grandes campos de dunas inativas, do tipo parabólicas.

Ainda de acordo com os autores, as campinas/campinaranas são tipos de vegetação que ocorrem sobre solos arenosos hidromórficos e areias quartzosas, típicas das bacias dos Rios Negro, Branco e Orinoco, com predominância na composição florística de espécies ou variedades amazônicas de aspecto raquítico, e pelo menos um gênero endêmico. Estas tipologias correspondem a diferentes estágios sucessórios da cobertura vegetal, e essas estão organizadas em função de gradientes de alagamentos, com as comunidades mais lenhosas sendo submetidas a períodos mais curtos de encharcamentos da área.

As tipologias vegetacionais de terra firme, matas de várzea e igapó; e campinaranas, são os elementos que mais se destacam na paisagem do município; e massas d'água, caracterizadas por sistemas fluviais meandriformes, sistemas arreicos formando campos encharcados originários de paleocanais, leques aluvionares isolados, cujo sistema de drenagem é formado principalmente pelos rios: de água clara (Catrimani), água preta (Água Boa do Univini), ambos afluentes do Rio Branco. Essa extensa área de cobertura vegetal, com predominância de mata de terra firme e áreas sazonalmente inundáveis como as várzeas na planície do baixo Rio Branco, igapós dos Rios Catrimani, Água Boa do Univini, Xeruini e Jufari; e as campinaranas isoladas entre meio a mata de terra firme (MORAIS, CARVALHO, 2013).

Segundo Carvalho (2012), esse tipo de vegetação, incluindo outros elementos existentes em áreas de ambientes úmidos na Amazônia, são devidos a duas fases: uma terrestre e outra aquática. A distribuição da vegetação é influenciada pelos fatores: duração das fases terrestre e aquática, denominada de sazonalidade climática; a estabilidade física do ambiente, por exemplo, o gradiente do relevo, influenciando a sedimentação, os processos erosivos, o fluxo dos sistemas fluviais e os impactos humanos. 
Figura 5 - Mapa de vegetação da área de estudo.

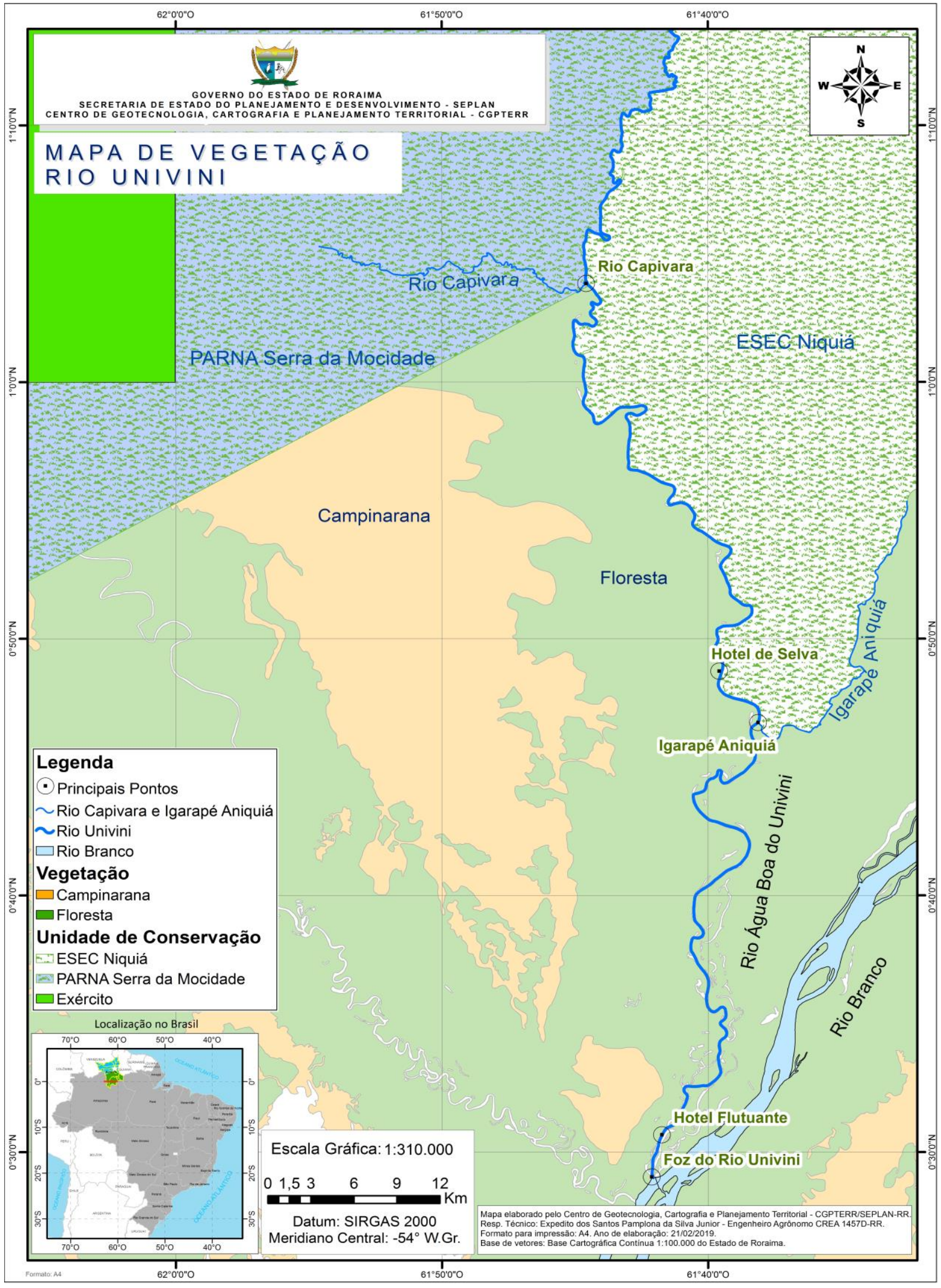

Fonte: SEPLAN, 2019. 


\subsubsection{Clima}

A classificação climática Köppen-Geiger, mais conhecida por classificação climática de Köppen. É o sistema de classificação global dos tipos climáticos. A mesma é baseada com origem na fitossociologia e na ecologia, da vegetação natural de cada região, sendo a expressão do clima nela prevalecente, e são considerados a sazonalidade e os valores médios anuais e mensais da temperatura do ar e da precipitação pluviométrica. O clima da área de estudo é classificado segundo os autores, como clima tropical quente e úmido, com os totais anuais de precipitação pluviométrica relativamente elevada que é de 1.750 milímetros.

Conforme Arouche, Pinheiro e Carvalho (2013), o regime térmico expressa os seguintes valores, segundo a CPRM: média anual $26,5^{\circ} \mathrm{C}$, resultado da máxima de $32,3^{\circ} \mathrm{C}$ e mínima de $21^{\circ} \mathrm{C}$, com amplitude térmica média de $11,3^{\circ} \mathrm{C}$. Julho é o mês mais frio, novembro é o mais quente. No baixo Rio Branco, a estação chuvosa começa em maio e estende-se até agosto-setembro, e durante esse período, o Rio Branco sobe aproximadamente entre 6 a 8 metros na cidade de Caracaraí.

Ainda de acordo com Arouche, Pinheiro e Carvalho (2013), no período de estiagem na cidade de Caracaraí a vazão média fica em torno de 1400 m3/s. Em média, o Rio Branco transporta $45 \mathrm{mg} / \mathrm{l}$ de sedimentos em suspensão, com mínimos na estiagem com cerca de 10 a $20 \mathrm{mg} / \mathrm{l}$ e picos na cheia de 70 a $80 \mathrm{mg} / \mathrm{l}$, caracterizando este rio não somente como de água branca típica, mas um padrão misto de água clara e branca. Com relação ao pulso de inundação, este ocorre uma vez ao ano, em que as águas sobem acima de 5 metros e permanecem cerca de 82 dias, sendo a referência a régua de Caracaraí.

\subsubsection{Hidrologia do Rio Água Boa do Univini}

Saint-Paul e Bayley (1979) relatam que o extenso sistema fluvial da Amazônia e a maior área hidrogeográfica do mundo são importantes fontes de alimentação e de transporte para a população amazônida, onde a influência na ecologia e climatologia é considerável. $\mathrm{Na}$ ecologia desenvolve-se uma ictiofauna mais rica que nos outros sistemas fluviais do mundo, enquanto na climatologia o período de cheias, os ecossistemas aquáticos recebem grande quantidade d'água, o que resulta no aumento de área e profundidade dos rios e lagos. Neste período ocorre a intercomunicação de vários lagos e rios, formando um único sistema. Já na 
época de seca, com a queda do nível d'água, os diferentes sistemas permanecem isolados, ou comunicam-se por canais.

Esse sistema fluvial, segundo Sioli (1950 e 1976) foi classificado em três tipos de água: água branca, água preta e água clara, entretanto, elas dependem da situação geológica nas regiões das cabeceiras e são caracterizadas por diferentes parâmetros de sua composição física e química.

Para Saint-Paul e Bayley (1979), os três tipos de água apresentam produtividade biológica, consequentemente, a produção pesqueira diferentes, pois dependem da situação limnológica. Portanto, as águas pretas, e até certo ponto as águas claras, podem ser classificadas como águas de baixo potencial pesqueiro. Em contrapartida, as águas brancas são consideradas as mais produtivas e de alta produção pesqueira.

Os rios Xeriuini, Jufari, Água Boa do Univini, Itapará e, em seus baixos cursos, os rios Anauá, Catrimâni e Jauaperi constituem as principais drenagens que cortam no sentido nortesul o chamado Pantanal Setentrional. Nesta Unidade Morfoescultural estão situadas integralmente duas unidades de conservação federais, o Parque Nacional do Viruá e a Estação Ecológica do Niquiá, igarapé afluente do Rio Água Boa do Univini, além de, parcialmente, o Parque Nacional Serra da Mocidade (LADEIRA, DANTAS, 2014).

De acordo com Barbosa (2005), o sistema hidrográfico da área em estudo é um intrincado emaranhado de fluxos de águas pretas e "mistas", variando a carga química e de sedimentos em função das chuvas e/ou enxurradas regionais. Além disto, a distribuição das chuvas e o arranjo arquitetural da drenagem também acabam se tornando indutores de diversidade vegetal (e paisagística) pela forte influência na distribuição de espécies adaptadas àquelas condições de solo e química da água.

O Rio Água Boa do Univini é um dos principais afluentes do Rio Branco, apresenta uma ictiofauna muito rica, sendo utilizado tanto para a pesca esportiva quanto para subsistência. Os locais estudados foram restritos ao leito do Rio Água Boa do Univini, composta por lagoas, lagos, ressacas e igarapés. Segundo Sioli (1967), a classificação das águas do Rio Água Boa do Univini são águas pretas, sendo considerado um rio raso (CREPALDI, 2014).

Para constatar o efeito da unidade de conservação sobre as populações de tucunaré, pertencentes as quatro espécies observadas no Rio Água Boa do Univini, foram avaliadas através da comparação das médias de comprimento, peso e número de peixes capturados entre 
as seis zonas de pesca do rio, pré-definidas em função da distância da unidade de conservação. Foi utilizado o software $R$ Core Team, também conhecido como Ambiente $\mathrm{R}$ dadas as suas características, para análise e interpretações dos resultados. Em face da ocorrência de resíduos heterocedásticos, o teste não-paramétrico de Kruskal-Wallys foi empregado para analisar os dados coletados, uma vez que os mesmos não apresentaram distribuição normal, usando o teste de Wilcoxon como teste pareado para comparação a posterior, quando a hipótese $\mathrm{H} 0$ foi rejeitada.

\subsection{COLETA DE DADOS}

A temporada de pesca esportiva no Estado de Roraima iniciou no mês de outubro de 2018 e finalizou em março de 2019, com uma pausa nas atividades de pesca na última quinzena de dezembro e reiniciando na primeira quinzena de janeiro (festas de Natal e Fimde-Ano). As coletas foram realizadas durante o período de temporada da pesca esportiva. Foram avaliados 98,9 km do trecho ao longo do Rio Água Boa do Univini, desde a foz do Rio Capivara com as coordenadas ( $1^{\circ} 03^{\prime} 50,40^{\prime \prime} \mathrm{N} ; 61^{\circ} 44^{\prime} 34,57^{\prime \prime} \mathrm{W}$ ) até a foz do Água Boa do Univini, conforme as coordenadas geográficas $\left(0^{\circ} 29^{\prime} 01,69^{\prime \prime} \mathrm{N} ; 61^{\circ} 42^{\prime} 07,07^{\prime} \mathrm{W}\right)$. De acordo com a Portaria Normativa 001/2011, nesse trecho do Rio Água Boa do Univini é permitida a pesca esportiva e para subsistência, ficando proibidas as demais categorias de pesca.

\subsubsection{Observação participante}

\subsubsection{Contribuições e aplicabilidade da observação participante}

A observação participante pode ser conceituada como:

Processo no qual o pesquisador estabelece um relacionamento multilateral e de prazo relativamente longo com uma associação humana na sua situação natural com o propósito de desenvolver um entendimento científico mais preciso daquele grupo avaliado (MAY, 2001: 177).

Através desse procedimento metodológico, o pesquisador tem um excelente recurso para uma inserção mais densa nas práticas e representações vivenciadas pelos pescadores esportivos, pois permite ao pesquisador uma análise mais delimitada e específica, devido a incursões mais constantes que se pode fazer no dia-a-dia das experiências da pesca praticada 
pelo pescador esportivo (PROENÇA, 2007). Ainda segundo esse autor, ocorrendo uma maior proximidade do contexto ou ambiente do grupo a ser investigado, o pesquisador poderá então efetuar interpretações sobre o seu objeto de estudo com maior correspondência ao modo como os próprios integrantes vivenciam sua experiência.

Diferentemente da entrevista, na observação participante o pesquisador vivencia pessoalmente o evento de sua análise para melhor entendê-lo, percebendo e agindo diligentemente de acordo com as suas interpretações daquele mundo; participa nas relações sociais e procura entender as ações no contexto da situação observada (PROENÇA, 2007).

Vale considerar ainda que a pesquisa através da observação participante insere o pesquisador num tempo e num ambiente correspondente à sua própria temporalidade de existência. No caso em tela, por exemplo, tal procedimento pode ser classificado como "história do tempo presente", considerando que no $98,8 \mathrm{~km}$ de trecho ao longo do rio em estudo, ou seja, desde o Rio Capivara, limite do Rio Água Boa do Univini com as Unidades de Conservação Parque Nacional Serra da Mocidade e a Estação Ecológica do Niquiá até a foz do Rio Água Boa do Univini com o Rio Branco, ocorrem dois empreendimentos operando com a pesca esportiva nesse trecho do Rio Água Boa do Univini. O primeiro é um Hotel de Selva, denominado Água Boa Amazon Lodge, atendendo estrangeiros, e o segundo uma Plataforma flutuante, denominado Porto Tur-Pesca Esportiva, operando com pescadores esportivos nacionais. Vale ressaltar que, ao longo do Rio Água Boa do Univini não há existência de comunidades ribeirinhas.

\subsubsection{1 Água Boa Amazon Lodge}

O Hotel de Selva, uma base fixa, fica localizado à margem direita do Rio Água Boa do Univini, com um salão principal, sala de refeição, sala de jogos e televisão, biblioteca, piscina e serviço de bar. A capacidade máxima de hospedagem do hotel é de 12 pescadores esportivos, com cada apartamento acomodando dois turistas. Localizado na coordenada geográfica: Latitude de $0^{\circ} 48^{\prime} 65^{\prime}$ ' N e Longitude de $61^{\circ} 39^{\prime} 34,73$ ” W, a uma altitude de 39 metros, conforme figura 6. 
Figura 6- Água Boa Amazon Lodge.

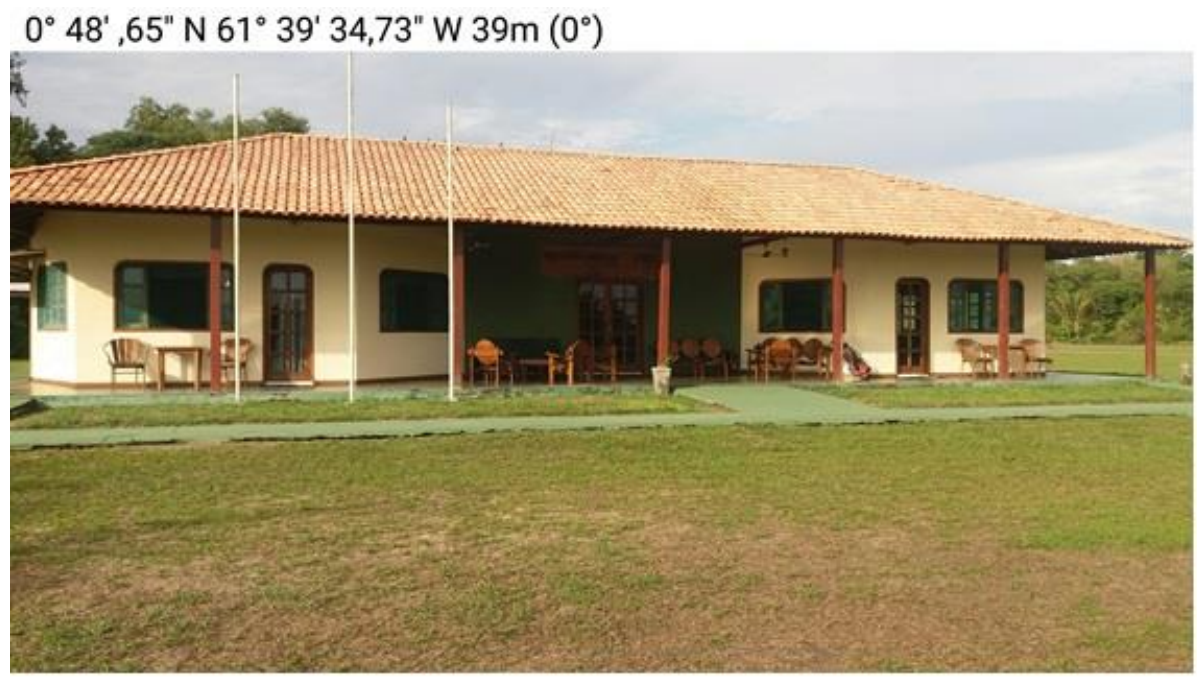

Fonte: O autor, 2019.

O hotel de selva tem um voo chart com avião tipo Caravan de Manaus para o lodge com uma duração de 2 horas, levando um grupo de turistas estrangeiros, e retorna para Manaus com outro grupo de turistas estrangeiros. O hotel possui uma pista de pouso de 1.200 metros de comprimento, licenciada pela Agência Nacional de Aviação Civil - ANAC. Os turistas estrangeiros, em sua maioria norte-americanos, chegam no hotel de selva no sábado pela manhã vindos de Manaus, passam a semana pescando e retornam no sábado seguinte de manhã de volta à Manaus, onde tomam o avião comercial para seus países de origem.

O início da temporada de pesca começou no dia 20 de outubro de 2018, sendo o mês de outubro a época mais alta da água com menor clareza. Este é um ótimo momento para os pescadores iniciantes com mais elenco cego para a estrutura do que a pesca esportiva. $\mathrm{O}$ término ocorreu no dia 30 de março de 2019, totalizando 162 dias de pesca esportiva. A água baixa é típica de janeiro a março, com mais pesca à vista e menos lançamentos cegos. Este é um ótimo momento para os pescadores intermediários e experientes da pesca esportiva, embora os iniciantes ainda se saiam bem. o período de pesca é o dia inteiro, o pescador esportivo sai do píer do hotel entre $7 \mathrm{~h}$ e $7 \mathrm{~h} 30 \mathrm{~min}$, pesca de manhã até às $12 \mathrm{~h}$. $\mathrm{O}$ almoço do turista e do guia de pesca é realizado no rio, no barco que conduz o pescador tem duas caixas térmicas, uma maior com água, cerveja, refrigerante, e a outra menor com sanduíches com recheios variados. O almoço e repouso tem uma duração de 1 hora, após esse intervalo continua a pesca no período da tarde, até às $16 \mathrm{~h}$ e/ou 17h, após esse horário, ocorre o retorno para o hotel, totalizando 9 horas de pescaria, entretanto, descontando o período de translado do píer do hotel para os locais de pesca (igarapé, ressacas, lagos e o Rio Água Boa do 
Univini) e o almoço, o pescador esportivo passa em torno de 7 a 8 horas pescando. Chegando no hotel, os turistas vão relaxar na piscina, degustando uma caipirinha acompanhada de petiscos.

Os clientes do Água Boa Amazon Lodge (hotel de selva) são pescadores esportivos e uma minoria de pescadores e observadores de pássaros são estrangeiros, vindos de todos os lugares do mundo, tais como: norte-americanos, australianos, canadenses, alemães, sulafricanos, etc. São pescadores praticantes da modalidade Flyfishing. Dos 100\% dos turistas que frequentam o hotel, cerca de $75 \%$ são norte-americanos e $35 \%$ são de diversos países do mundo, conforme mostra a figura abaixo.

Figura 7 - País de origem dos pescadores esportivos na temporada 2018 - 2019.

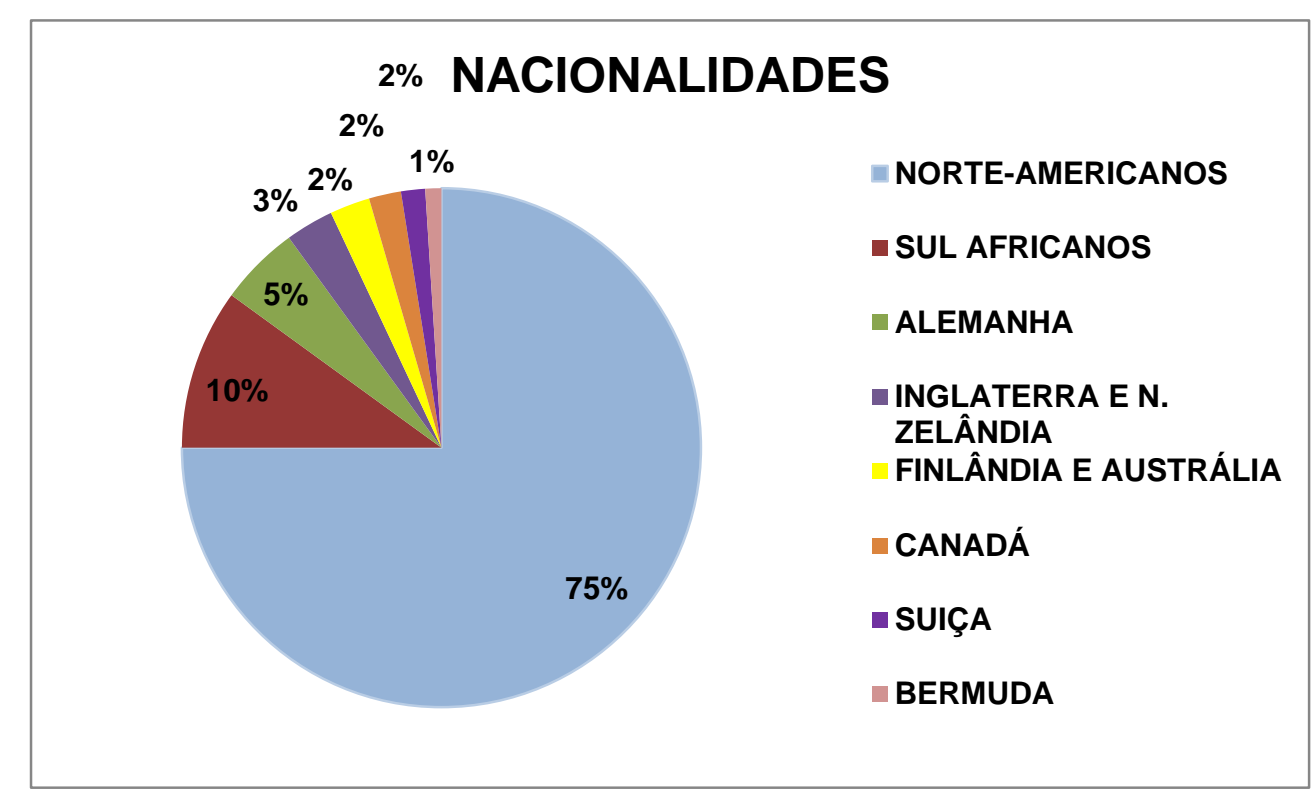

Fonte: O autor, 2019.

Pesca com mosca ou Flyfhishing é uma das mais antigas modalidades e de grande apelo para o pescador. Essa modalidade de pesca é praticada principalmente por turistas estrangeiros. Segundo Oliveira (2017), as moscas são as iscas artificiais mais antiga citadas em escritos do período da Dinastia Shang (2.000 a.C.), onde comenta-se o uso de moscas artificiais para pescar, considera-se que a modalidade começou na Macedônia. As moscas são iscas artificiais confeccionadas artesanalmente com pelos, penas, fios de plástico e linhas de costura, essa isca simula um inseto ou o alimento natural de alguns peixes. As iscas podem ser fabricadas artesanalmente pela maioria dos pescadores amadores/esportivos aficionados pela pesca Flyfishing, o que resulta numa terapia adicional. Todavia, diversos fabricantes produzem essas iscas em larga escala comercial, observar figura abaixo. 
Figura 8 - Fabricação artesanal da mosca (isca).
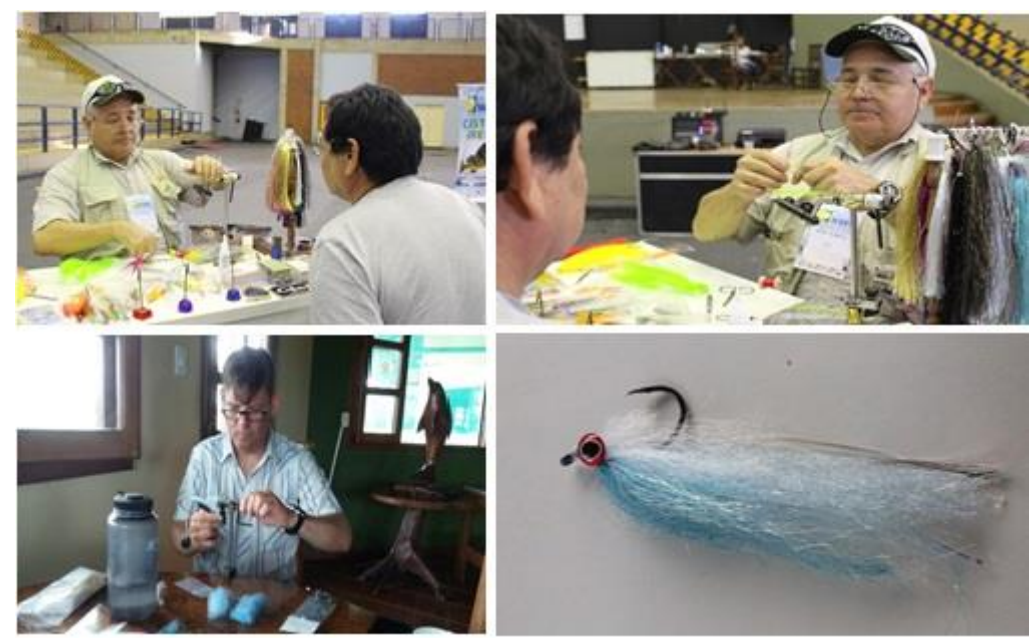

Fonte: O autor, 2019.

A pesca com mosca ou Flyfhishing é realizada utilizando uma vara comprida flexível, uma carretilha semelhante a uma bobina comum, que servem como armazém da linha e não exercem nenhuma função de arremesso. Elas são únicas no sentido de que não possuem peso, e seu lançamento depende de linhas grossas, varas especiais para que sejam projetadas ao respectivo alvo, além de anzol simples e sem farpas, conhecidos por "mosca". A pesca com mosca envolve estudo, treino e persistência, sendo o principal fator aprender a dominar a linha, ou seja, dominar a técnica do lançamento, também conhecida como Casting, conforme figura no detalhe abaixo.

Figura 9 - Modalidade de pesca com Fly-fishing (mosca).
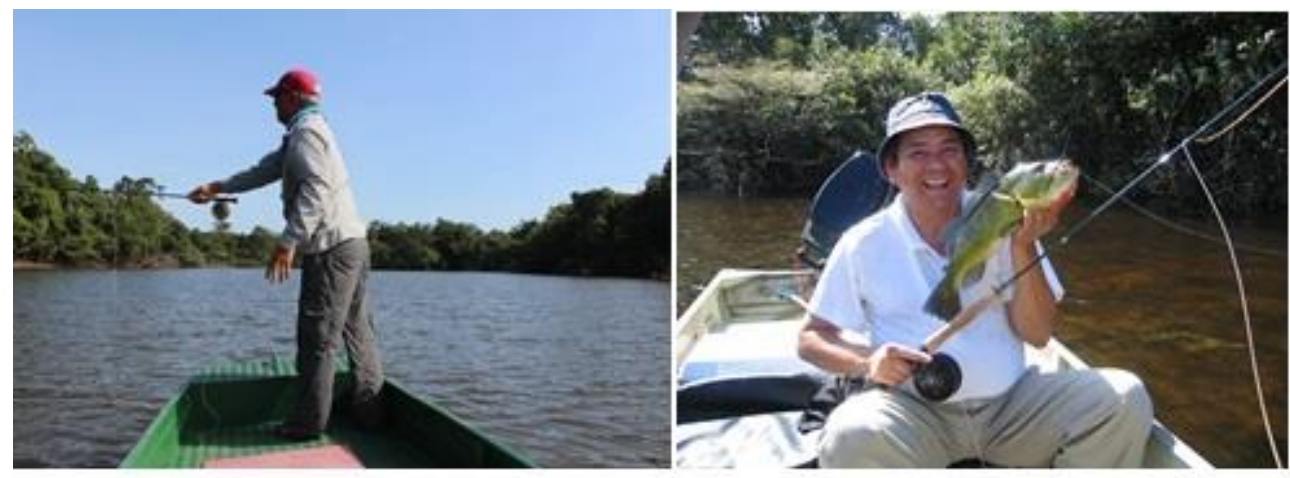

Fonte: O autor, 2019.

Essa modalidade de pesca causa menos estresse nos peixes devido à consciência ambiental desse pescador, e encontra-se em franca ascensão no Brasil. 
Outro fator importante praticado na modalidade Flyfishing observado nas zonas de pesca praticada pelo hotel de selva e o maior tempo explorado no pesqueiro pelo pescador, porque quando chegam nos locais de pesca, o guia de pesca desliga o motor e conduz o barco com varejão, evitando todo o tipo de barulho e principalmente "torricar" o lago para não espantar o peixe, com isso a pesca tornando-se mais explorada e longa nesses pesqueiros.

O guia de pesca no empreendimento tem um papel importante na conscientização ambiental, isto é, durante a semana de pesca, se no primeiro dia o turista pegar 100 peixes no primeiro lago, por exemplo, o guia de pesca imediatamente leva esse pescador para outro ponto de pesca, deixando o lago anterior em descanso. Com essa prática, fazem o manejo do corpo d'água (igarapé, ressaca, lagoas, lagos e o rio). Essa consciência adquirida pelos guias de pesca visa à manutenção do estoque pesqueiro até o final da temporada. A temporada inicia em outubro e finaliza em março. Uma das preocupações do hotel é não fazer rotatividade de guias de pesca.

Os guias de pesca praticamente são os mesmos e há muitos anos trabalham no hotel, por exemplo, José Rodrigues (Zezinho) tem 22 anos trabalhando como guia de pesca, enquanto o Jamin Batista (Irmão) com 17 anos, Valdeir Goes (Preto) com 15 anos, Jerbison Alves (Caboco) com 11 anos, Ilson Costa (Bacaba) com 10 anos e o mais novo é o Samuel Almeida (Mutum) com 8 anos de atividade como guia de pesca no empreendimento. Os guias de pesca recebem formação de capacidades no setor visando melhorar a qualidade dos serviços oferecidos, transmitir noções de educação ambiental, estimular o pesque-e-solte, o uso de iscas artificiais e de anzol sem farpa (mosca), e repassar noções de segurança na navegação e no uso de equipamentos.

Existe um 'acordo de cavalheiros' entre o Água Boa Amazon Lodge e a Porto Tur Pesca Esportiva no zoneamento desse recurso hídrico para a pesca. O hotel de selva pode pescar da foz do rio Capivara (é a área do entroncamento do Rio Água Boa do Univini com o limite das Unidades de Conservação Parque Nacional Serra da Mocidade e Estação Ecológica do Niquiá - $1^{\circ} 03^{\prime} 50,40^{\prime \prime} \mathrm{N}, 61^{\circ} 44^{\prime} 34,57^{\prime}$ 'W) até o Estirão do Mendonça ( $0^{\circ} 41^{\prime} 26.83^{\prime \prime} \mathrm{N}$, $\left.61^{\circ} 38^{\prime} 34.36^{\prime \prime} \mathrm{W}\right)$, e a Porto Tur - Pesca Esportiva pesca do Estirão do Mendonça $\left(0^{\circ} 41^{\prime}\right.$ $\left.26.83^{\prime \prime} \mathrm{N}, 61^{\circ} 38^{\prime} 34.36^{\prime \prime} \mathrm{W}\right)$ até a foz do Rio Água Boa do Univini com o Rio Branco ( $0^{\circ} 29^{\prime}$ $01,69^{\prime \prime} \mathrm{N}, 61^{\circ} 42$ ' $\left.07,07^{\prime \prime} \mathrm{W}\right)$.

Com relação aos barcos que atuam nos pesqueiros, os mesmos são equipados com estrados inteiros, materiais de salvatagem e varejão. Os barcos mencionados têm a finalidade 
de atender dois pescadores por vez. Em função das características do rio, que ao longo do seu trecho até a foz do Rio do Água Boa do Univini, ocorre o surgimento de bancos de areias, formando praias, os barcos utilizados no início da temporada (outubro) são de alumínio, com comprimento entre 5 e 6 metros, equipados com motores de popa a hélice, modelo Mercury com potência de 25 HP. Esses barcos com esses motores são usados até o mês de dezembro, dependendo do nível da água do rio. A partir de janeiro são utilizados os barcos com motor turbo, modelo Yamaha de $30 \mathrm{HP}$, devido ao baixo nível das águas do rio, em alguns trechos do rio a lâmina d'água ficam menor do que $20 \mathrm{~cm}$ de profundidade. Esses barcos e motores são considerados satisfatórios para a pescaria no hotel.

Prince's (2009), espécies de peixes identificados e capturados pela pesca esportiva no Rio Água Boa do Univini: Tucunaré-Açú, Tucunaré Paca (Cichla temensis), Tucunaré Borboleta (Cichla orinocensis), Tucunaré Tauá (Cichla monoculus), Tucunaré Amarelo (Cichla ocellaris), Pirarucu (Arapaima gigas), Matrinchã (Brycon spp.), Acará-Açú (Astronotus ocellatus), Traíra (Hoplias malabricus), Bicuda (Boulengerrella maculata), Peixe Cachorro (Acestrorhynchus spp.), Jacundá (Crenicichla spp.), Apapá (Pellona castelnaeana), Pacú (Mylossoma spp.), Piranha (Serrasalmus spp.), Aruanã (Oesteoglossum spp.), Surubin (Pseudoplatystoma fasciatum), Pirarará (Phractocephalus hemioliopetrus). Percebe-se existir uma grande densidade de peixes, e mesmo à medida que passa a temporada e aumenta a pressão de pesca pelos pescadores, os peixes não diminuíram sua ação nos ataques às iscas artificiais.

Toda a instalação do Hotel de Selva tem fossa séptica para a coleta de resíduos humanos e da cozinha. Com relação ao sistema de iluminação, a energia fornecida vem de motor a diesel, sendo ligado o motor às 17 horas, momento em que o turista chega da pescaria, passa a noite funcionando e é desligado na manhã seguinte, às 8 horas. Das 8 até as 17 horas o local fica sem energia. Há uma preocupação ambiental em não poluir o solo com despejo de óleo diesel.

Os resíduos sólidos são separados em cestos grandes, de acordo com sua categoria: metal, plástico e papel são selecionados, separados, amassados e ensacados e levados para o município de Caracaraí para reciclagem.

\subsection{Porto Tur - Pesca Esportiva}

O início da temporada de pesca na Porto Tur - Pesca Esportiva foi de 19 de outubro de 2018 até 05 de janeiro de 2019, totalizando 79 dias de pesca. O hotel é uma estrutura 
flutuante, situado nas coordenadas geográficas: Latitude de $0^{\circ} 30^{\prime} 40,10^{\prime}$ ' $\mathrm{N}$ e Longitude de $61^{\circ} 41^{\prime} 44,25^{\prime}$ W, e uma altitude de 27 metros. No Brasil os níveis de água, em um ciclo de dez anos, a maioria dos anos a menor água do ano coincide com janeiro, fevereiro, março e abril. Deve-se notar que, em um ciclo normal de dez anos, haverá semanas, meses ou até mesmo estações onde os níveis de água não caem ao ponto em que a pesca à vista seja possível. Isso ocorre no Rio Água Boa do Univini. Durante esses períodos, a pesca é boa, com ótimas capturas ao longo do período de pesca esportiva.

Essa estrutura flutuante é composta de salão de refeições, jogos recreativos e 9 suítes climatizadas para os turistas, dois barcos de apoio, o Rainha Ester e o Gran Sabana, para acomodar os funcionários e visitantes. Em terra firme, tem uma cozinha de acampamento e um barracão para os piloteiros armarem suas redes de dormir, além de botes com motores de popa, conduzidos por piloteiros (barqueiros) com larga experiência em navegar no Rio Água Boa do Univini e demais rios da região (Figura 10).

Figura 10 - Porto Tur - Pesca Esportiva.

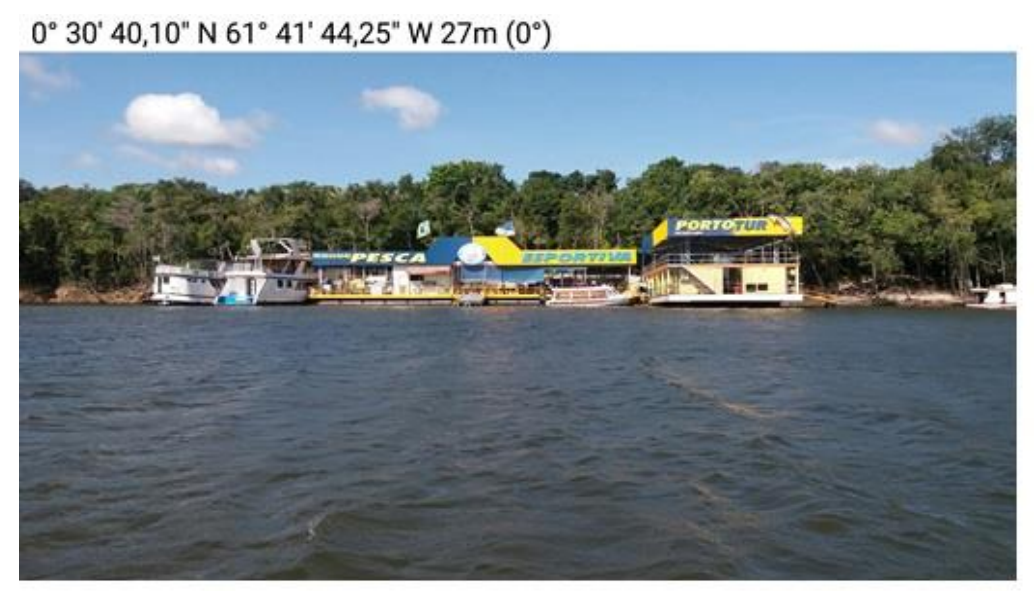

Fonte: O autor, 2019.

A empresa trabalha com um lema de conscientização ambiental focado na preservação da ictiofauna local.

Oferece um pacote turístico de 5 dias de pesca. Nesse pacote estão inclusos o translado dos turistas nos trechos Boa Vista - Caracaraí - Boa Vista por via terrestre, em micro-ônibus climatizado, e bebidas em geral. O translado dos turistas nos trechos Caracaraí - Rio Água Boa do Univini, região do baixo Rio Branco - Caracaraí é feito por via fluvial, através de uma lancha rápida de 22 lugares, equipada com um motor de $250 \mathrm{HP}$, além de petiscos e bebidas.

A pesca de arremesso em geral é feita embarcada com dois pescadores e um guia por cada voadeira, e as iscas são cuidadosamente escolhidas conforme a zona pesqueira e o tipo e tamanho do tucunaré a ser pescado. As voadeiras partem do píer do hotel flutuante de manhã 
entre $7 \mathrm{~h}$ e $7 \mathrm{~h} 30 \mathrm{~min}$, e retornam entre $11 \mathrm{~h} 30 \mathrm{~min}$ e $12 \mathrm{~h}$ para o almoço, com intervalo de duas horas para o descanso do turista. Retorna para pescar entre $14 \mathrm{~h} 15 \mathrm{~h}$ e retorna entre $18 \mathrm{~h}$ e $19 \mathrm{~h}$ para a base de apoio.

Geralmente, os pescadores levam entre três e quatro varas para essa pescaria, cada qual preparada para um tipo de isca artificial, ou o guia pode trocar a isca no rio para o turista. Uma vara para as pesadas iscas de hélices, outra mais leve para as iscas de superfície e meiaágua e uma terceira para as iscas como jigs e twitchs baits (iscas de contração muscular). Nessa modalidade de pesca de arremesso, as varas devem ser respeitadas em suas especificações de peso, caso o pescador esportivo extrapolar o peso indicado na vara de pesca, pode acarretar quebra após vários arremessos, por fadiga. O pescador, no momento da compra, deve também checar nas embalagens o peso da sua isca artificial para usar corretamente na hora da pescaria com seu caniço de pesca.

Na pescaria de tucunarés no Rio Água Boa do Univini, a pesca é realizada no sistema Baitcast (arremesso) com emprego de molinete e carretilha. Estes equipamentos são de extrema importância e com eles são possíveis arremessos mais certos e bem direcionados. Os modelos são variados, podendo existir muitos tipos de materiais, perfil, freio, recolhimento, arremesso, fricção, etc. As varas de pescar possuem diversos tamanhos e espessuras, são feitas de vários materiais: fibra, carbono, grafite ou outros materiais, possuem tipos de ações como lentas, rápidas, ultra-rápidas, médias e casting. A influência destes materiais, do peso, espessura e tamanhos influenciam nos arremessos e em quais tipos de peixes o pescador gostaria de fisgar. A qualidade da linha de pesca é uma das principais preocupações para uma boa pescaria. Além da qualidade, outro ponto deve ser o seu objetivo. Se a busca é peixes mais pesados ou maiores, linhas mais espessas são essenciais. As linhas de monofilamentos e multifilamentos são as mais utilizadas nas pescarias. As iscas mais utilizadas na modalidade de arremesso são as hélices, as poppers, as zaras, os jigs e as iscas de meia-água entre 10 e 16 centímetros, além de iscas denominadas de twitch baits, que trabalham pouca coisa abaixo da superfície, todavia, não possuem barbelas como as iscas de meia-água. O anzol certo é fundamental para o sucesso de uma boa pescaria. Tenha em seu apetrecho de pesca diversos tipos e tamanhos de anzóis. Busque o anzol ideal para o tipo de peixe desejado e tenha cuidado ao manusear o material. 
Figura 11 - Modalidade de pesca com carretilha e/ou molinete.

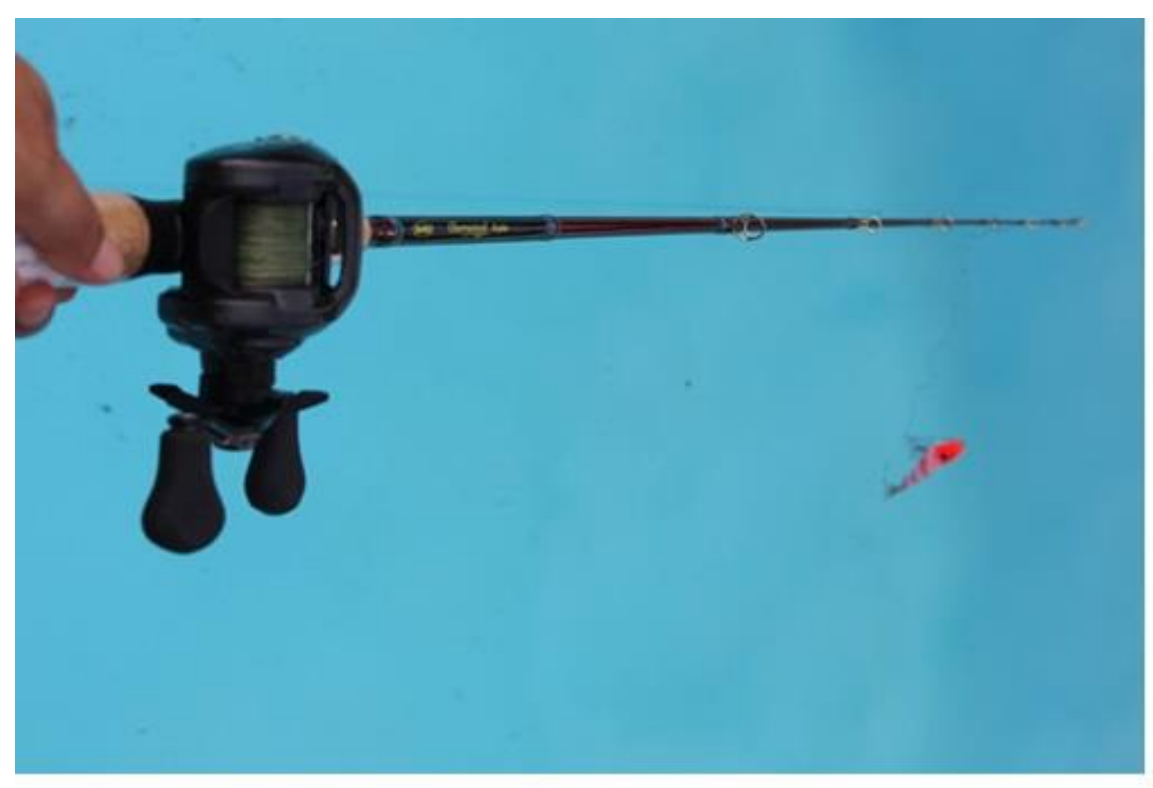

Fonte: Giselma Tonelli, 2019.

$\mathrm{Na}$ temporada de pesca, uma das preocupações do hotel flutuante é não fazer rotatividade de guias de pesca. Os guias de pesca têm muitos anos trabalhando no hotel flutuante, por exemplo, Renato Rodrigues Moura tem 15 anos trabalhando como guia de pesca, enquanto o Júlio dos Santos, Evaldo Garcia, Francisco Leite, Izais Cezário e Marquison Sousa atuam como guias de pesca entre 5 a 10 anos, e o mais novos são Daniel Filho e o Cleudo Nascimento que operam como guias de pesca entre 1 a 5 anos no empreendimento.

Com a existência de muitos bancos de areia na época de seca, o operador atua com motores de $15 \mathrm{HP}$ e, em algumas situações, uso de motores elétricos para poder chegar na área de pesca.

\subsubsection{Pesca experimental do tucunaré}

Para determinação da influência da unidade de conservação, o Parque Nacional Serra da Mocidade e a Estação Ecológica Niquiá como fontes alimentadoras da espécie alvo, foi realizado a pesca com a finalidade de captura de indivíduos de tucunaré nas parcelas experimentais, neste caso, as áreas zoneadas ao longo do trecho do rio em questão. $\mathrm{Na}$ pescaria foram utilizados barcos motorizados com motor turbo tipo Jet de $40 \mathrm{HP}$ ou hélices, com 5,5 metros de comprimento por 1,32 metros de largura, totalizando 7,26 metros quadrados, apropriado para navegar no rio no período de seca. Os barcos estreitos e longos 
são estáveis para lançamento de moscas e têm uma plataforma de elevação acima do motor na popa. A pesca foi feita por dois pescadores esportivos, como forma de padronização do esforço de pesca nas capturas dos tucunarés. Para gerar estimativas de volume de capturas nas zonas de pesca, foi aplicada uma metodologia baseada no cálculo da captura por unidade de esforço (CPUE). Quanto às unidades de esforço passíveis de uso, a CPUE é definida como captura por dia de pesca efetivo de uma embarcação, isto é, número de peixes por pescador por barco, ou número de peixes por pescadores por dia. Entende-se como dia de pesca efetivo aquele dia que os pescadores esportivos realizam a pesca no período da manhã e da tarde.

A pescaria dos tucunarés foi feita pelos pescadores esportivos estrangeiros, pelo fato desses pescadores quando saem de seus países de origem para pescar na Amazônia, em particular no Rio Água Boa do Univini, eles efetivamente pescam oito horas por dia, durante os sete dias de pescaria. Por outro lado, os pescadores esportivos nacionais, muitas vezes não vão pescar, para desfrutarem da tranquilidade e beleza do lugar. Devido ao exposto, essa foi a razão da escolha dos pescadores internacionais pelo autor para realização das pescarias experimentais, ao invés dos pescadores nacionais.

$\mathrm{O}$ rio foi dividido em seis zonas e cada guia de pesca só trabalha na sua zona, o guia de pesca já tem essa consciência e orienta o pescador. Ao longo da semana, o guia de pesca realiza o manejo das zonas com os pescadores. Normalmente, o pescador esportivo pescará na mesma zona no primeiro e no último dia. As corridas mais longas do hotel são as zonas 1 e 6 , ambas as corridas demoram cerca de uma hora e meia em cada sentido. Na zona 5 a corrida tem duração de 50 minutos. As zonas 2 e 4 são corridas de 20 a 30 minutos e a corrida para a zona 3 é inferior a 10 minutos. O pescador vai girar através de todas as zonas para que todos no hotel tenham aproximadamente a mesma quantidade de tempo de viagem durante a semana.

O Rio Água Boa do Univini ao longo de sua área destinada à pesca esportiva tem um zoneamento para manejo das áreas, esse manejo tem a função de descansar a área por 48 horas, só após pesca-se nessa área e também para evitar o guia de pesca invadir a zona do outro. Todo o rio é dividido em seis zonas de pesca com seus respectivos guias de pesca. No presente estudo as áreas zoneadas foram consideradas as parcelas experimentais. Em cada zona ocorreram três dias de pesca consecutiva, a quantidade do pescado capturado é a média dos três dias de pesca em cada zona. O período efetivo de pesca experimental por barco foi de 9 horas.

Os peixes fisgados foram embarcados com auxílio de alicate de contenção sem proteção de borracha, foi medido o comprimento total do animal com uma trena modelo 
Stanley $5 \mathrm{~m} / 16$ ' e o peso foi realizado com o alicate de contenção modelo Boga Grip, marca Fish Grip, homologado pela International Game Fishing Association - IGFA com pesagem em libras e aferição de recordes mundiais de captura. O comprimento total é a medida entre o focinho do peixe e o final da porção superior da nadadeira caudal. Nos casos em que pormenores anatômicos não torne praticável essa mensuração com mais precisão, no caso de alguns pouquíssimos peixes apresentando alguma deformidade na nadadeira caudal, a medida foi tomada na porção inferior ou no ponto em que ela atingisse o maior comprimento. Todos os peixes foram medidos em decúbito lateral sobre o banco do barco. Em momento seguinte, ocorreu a soltura dos peixes na água, conforme a figura abaixo.

Figura 12 - Medidas de peso e de comprimento dos peixes capturados.
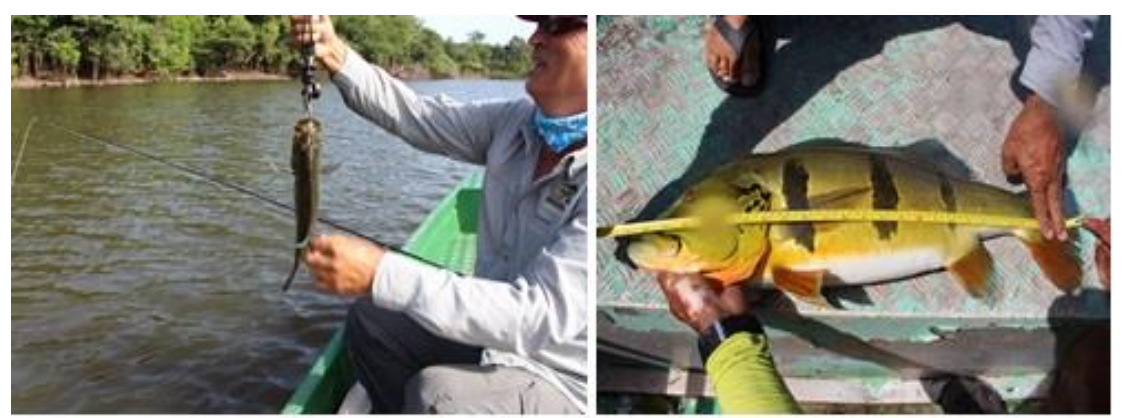

Fonte: O autor, 2019.

O Rio Água Boa do Univini nos meses de janeiro a março seca bastante, formando bancos de areias ao longo de todo o rio, dificultando inclusive a navegabilidade.

As capturas foram realizadas pelo método ativo, isto é, por meio de arremesso e imediato recolhimento da isca. Os apetrechos usados na pescaria experimental foram varas de pesca equipadas com "Fly-Fishing” utilizadas pelos próprios pescadores esportivos, com 2 pescadores em cada barco. O Rio Água Boa do Univini é o único rio em que se pesca apenas com mosca (Fly-Fishing). Esta cobiçada designação foi concedida após longas negociações com o Governo do Estado de Roraima, através da Portaria Normativa 001/2011/FEMARH. Este nível de proteção sem precedentes assegura que os peixes no rio não estão sujeitos a desgaste excessivo de vários conjuntos de agudos, mas também garante que a pesca no Água Boa do Univini permaneça sólida durante toda a temporada.

Foi utilizado alicate de contenção modelo Boga Grip sem proteção de borracha nas extremidades (por ser mais barato e o mais vendido no comércio) com pesagem em libras, alicate de bico para extração do anzol e trena modelo Stanley $5 \mathrm{~m} / 16$ '.

O procedimento adequado de segurar um peixe é aquele que menos o estressa, mantêlo sempre na posição horizontal, para evitar quaisquer danos físicos ao animal. Esses peixes 
capturados foram embarcados, o pescador utilizou equipamentos citados acima que ajudaram no manuseio do mesmo, trazendo menos danos no momento da sua pesagem e medição do comprimento. Após esses procedimentos, imediatamente os peixes eram devolvidos na água para que sofressem o menor estresse possível.

A soltura desses peixes ocorria em águas calmas, sem correntezas, evitando que peixe se esforce sem necessidade. O pescador, com cuidado segurava pela cauda, esperando que o peixe se recuperasse, até que conseguir nadar normalmente. Evitando segurá-lo pela boca ou pelos opérculos, para que ele possa respirar. Um procedimento muito importante é colocar o peixe sempre no sentido da boca voltada contra a correnteza para que a água entre pela sua boca passe pelas guelras e saia pelo opérculo. O pescador não colocava o peixe a favor da correnteza e não fazia o movimento de "vai e vem" na água. Esse movimento incorreto pode modificar a forma de entrada natural de água, podendo ocasionar o comprometimento das guelras. 
Figura 13 - Zona de pesca do Rio Água Boa do Univini.

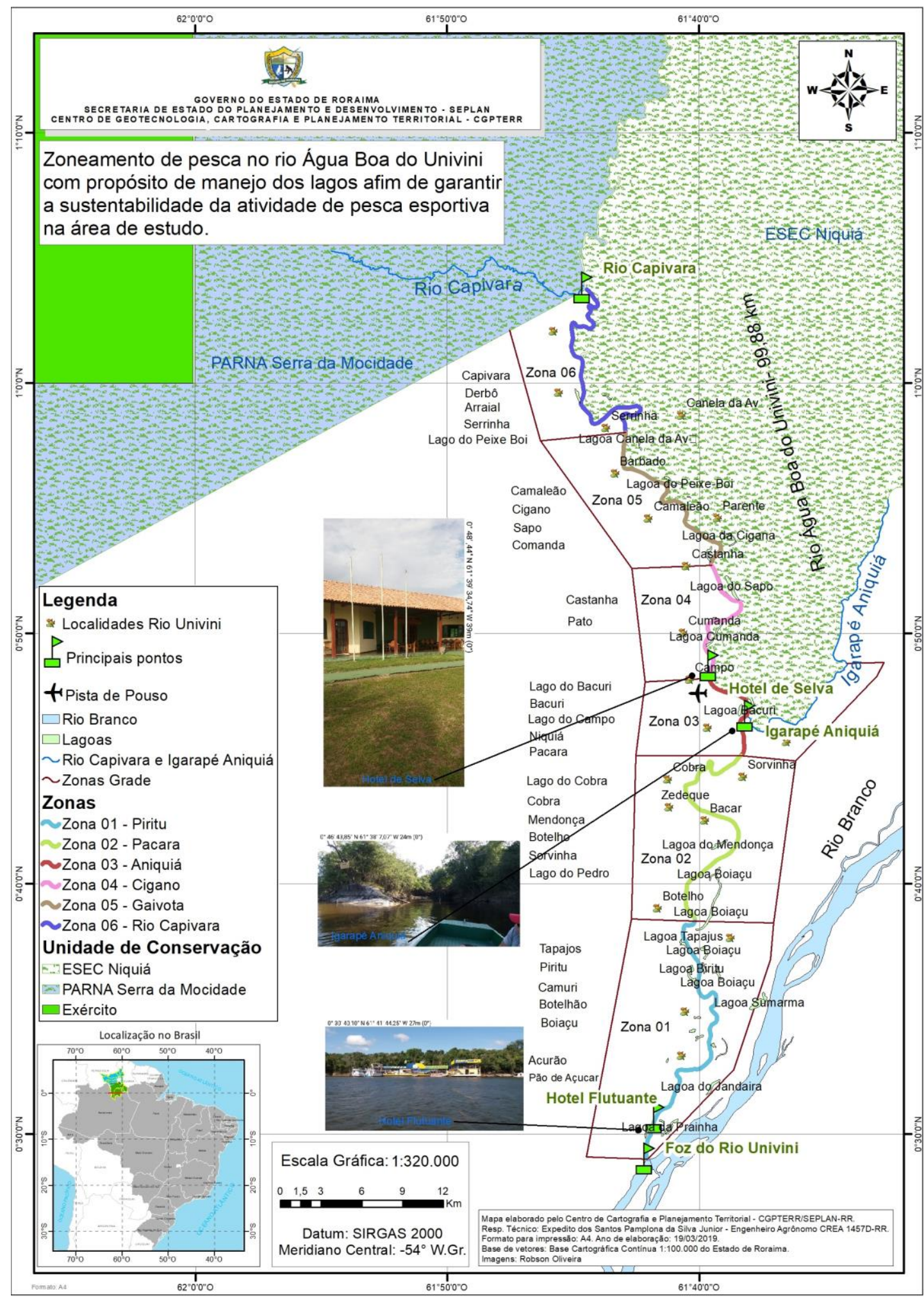

Fonte: SEPLAN, 2019. 


\subsection{ANÁLISE DE DADOS}

\subsubsection{Definição das Capacidades de Cargas}

Para estudo da capacidade de carga do Rio Água Boa do Univini na região do baixo rRo Branco, em Roraima, foram selecionadas técnicas de pesquisa em turismo, por meio de questionários referentes ao levantamento do perfil dos pescadores esportivos estrangeiros e nacionais e guias de pesca (LAKATOS 2003), aplicação da metodologia indica por Cifuentes et al. (1992), adaptada às condições do ambiente de água doce, pois ela incorpora aspectos à dinâmica do ambiente aquático no processo de avalição da capacidade de carga da pesca esportiva, para o cálculo do número de pescadores esportivos considerado adequado para uma determinada área. A finalidade de controlar a utilização dos recursos naturais como atrativos turísticos, por meio de um planejamento, objetiva minimizar os efeitos negativos e maximizar os efeitos positivos, com a distribuição dos fluxos turísticos, evitando um acúmulo excessivo de pescadores nas áreas mais frágeis.

A metodologia originalmente proposta para estimação da capacidade de carga do turismo em ambientes terrestres, proposta por Cifuentes et al. (1992), consiste de três etapas: Estimativa da Capacidade de Carga Física (CCF), estimativa da Capacidade de Carga Real (CCR) e estimativa da Capacidade de Carga Efetiva (CCE). Cada um dos níveis, na ordem mencionada, representa uma capacidade de carga corrigida em relação à anterior. Em razão disso a Capacidade de Carga Física (CCF) será sempre maior do que a Capacidade de Carga Real (CCR), que por sua vez poderá ser maior ou igual à Capacidade de Carga Efetiva (CCE). A relação entre os níveis pode ser representada da seguinte forma: $\mathrm{CCF}>\mathrm{CCR} \geq \mathrm{CCE}$ (CIFUENTES, et al, 1992). (Figura 14)

Figura 14 - Representação esquemática dos níveis de capacidade de carga corrigidos.

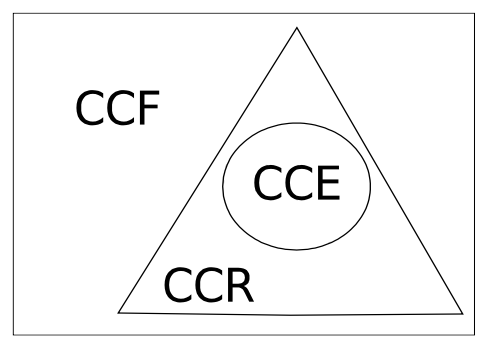

Fonte: Cifuentes et al., 1992 


\subsection{DETERMINAÇÃO DAS CAPACIDADES DE CARGAS}

O estudo para a determinação da capacidade de carga do Rio Água Boa do Univini foi desenvolvido em três etapas:

Etapa I - Levantamento bibliográfico para a elaboração do projeto. De acordo com Lakatos (2003), servirá como primeiro passo, para se saber em que estado se encontra atualmente o problema, que trabalhos já foram realizados a respeito e quais as opiniões reinantes sobre o assunto e, assim, permitirá que se estabeleça um modelo teórico inicial de referência, da mesma forma que auxiliará na determinação das variáveis e elaboração do plano geral da pesquisa;

1) Elaboração do plano de pesquisa para determinação da capacidade de carga da pesca esportiva e definição da reposição do estoque pesqueiro de tucunaré na área de estudo submetido à Universidade Federal do Amazonas - UFAM, por intermédio da Pró-Reitoria de Pesquisa e Pós-Graduação (PROPESP) no Exame de Seleção de candidatos para o ingresso no I Semestre de 2016 nos cursos de Mestrado e Doutorado do Programa de Pós-Graduação em Ciências Pesqueiras nos Trópicos (PPG - CIPET), através do Edital No 049/2015PROPESP/UFAM ;

Etapa II - Aula de Qualificação de Docência;

2) Apresentação do respectivo projeto ao Programa de Pós-Graduação em Ciências Pesqueiras nos Trópicos (PPG-CIPET). Aula de Qualificação de Doutorado do discente ROBSON OLIVEIRA DE SOUZA. Título da Aula: "Capacidade de carga de pesca esportiva nos rios Água Boa do Univini, Xeriuini e Itapará, na região do baixo Rio Branco, Roraima, Brasil". Data: 30/06/2017 às 9h (Sexta-feira). Local: sala de alunos do PPG CIPET, $2^{\circ}$ andar do bloco PPG FCA-ICB, ao lado do bloco $\mathrm{M}$ e prédios do ICB Minicampus - Setor Sul. A Banca de professores avaliadores sugeriu mudança do título da Tese, que ficou assim: "Capacidade de carga de pesca esportiva no Rio Água Boa do Univini, na região do baixo Rio Branco, Roraima, Brasil”.

3) Etapa III - Levantamento das características da pesca esportiva no Rio Água Boa do Univini; 
3.1) Estudos de campo:

3.1.1 Determinação da capacidade de carga para a prática da pesca esportiva, pesca experimental visando quantificar o potencial pesqueiro em função das Unidades de Conservação;

3.2) Aplicação de formulário estruturado com questões fechadas, apresentando perguntas de múltipla escolha, abrangendo várias facetas do mesmo assunto. Através de amostragem classificada por Lakatos (2003, grifo nosso), como perguntas de estimação ou avaliação, que consistem em emitir um julgamento através de uma escala com vários graus de intensidade para um mesmo item. As respostas sugeridas são quantitativas e indicam um grau de intensidade crescente ou decrescente. Responderam ao questionário e participaram das entrevistas durante a temporada de pesca 2018/2019, os pescadores esportivos da Porto Tur Pesca Esportiva e do Água Boa Amazon Lodge (nacionais e estrangeiros), o pesquisador também realizou entrevista com os guias de pesca. Após a coleta dos dados, procedeu-se a tabulação e à análise dos dados coletados.

Serão apresentadas a seguir as fórmulas para calcular cada uma das capacidades de cargas acima mencionadas.

\subsubsection{Determinação da Capacidade de Carga Física (CCF)}

A Capacidade de Carga Física (CCF) entende como o limite máximo de visitas que pode ser feito em um sítio com espaço definido, em um tempo determinado. É definida com base na relação entre o horário e tempo de visita, o espaço disponível para a visitação e a necessidade de espaço por visitante (CIFUENTES, et al, 1992). Pode expressar-se pela fórmula:

\section{$\mathrm{CCF}=\mathrm{V} / \mathrm{a} \times \mathrm{S} \times \mathrm{t}$}

Onde:

V/a = Visitantes / área ocupada. Com relação à área ocupada por um visitante, será assumido o valor estimado para ambiente de água doce, uma vez que essa metodologia é aplicada em ambiente terrestre de áreas protegidas. No caso em tela, será utilizado barco para motor hélice com um padrão estimado de $7,63 \mathrm{~m}^{2}$. A pesca praticada na área de estudo é embarcada. 
$\mathrm{S}=$ Superfície disponível para uso público.

$\mathrm{t}=$ Tempo necessário para executar a visita.

Cifuentes (1992, pp.9-10) enfatiza que

O cálculo da CCF deve necessariamente basear-se em alguns critérios e pressupostos básicos:

a) Em geral, estima-se que uma pessoa requer $1 \mathrm{~m}^{2}$ de espaço para mover-se livremente;

b) A superfície disponível será determinada pela condição do sítio avaliado. Mesmo no caso de áreas abertas, a superfície disponível poderia ser limitada por características ou fatores físicos (rochas, rachaduras, ravinas, etc.) e por limitações impostas por razões de segurança ou fragilidade no caso das trilhas, limitações de espaço também são dadas pelo tamanho dos grupos e pela distância que deve ser mantida prudencialmente entre os grupos;

c) O fator tempo é uma função do tempo de visita e o tempo real necessário para visitar o sítio.

De acordo com Cordeiro, Körössy e Selva (2013, p. 9)

A capacidade biofísica do espaço, no entanto, não é suficiente para atestar a quantidade de visitantes que o território é capaz de suportar. Por este motivo, variáveis relacionadas às características físicas, sociais, ambientais, biológicas, de visitação e de manejo do local precisam ser consideradas. Neste sentido, a Capacidade de Carga Real (CCR) irá aplicar Fatores de Correção (FC) ao quantitativo de visitantes identificados no cálculo da Capacidade de Carga Física (CCF).

\subsubsection{Determinação da Capacidade de Carga Real (CCR)}

A Capacidade de Carga Real (CCR) é definida como o limite máximo de visitantes permitido em uma localidade, determinado a partir da Capacidade Física, uma vez que fatores de correções ou limitantes derivados das características particulares do local são aplicados. Os fatores de correções se obtêm considerando as variabilidades ambientais, físicas, ecológicas e de manejo.

A Capacidade de Carga Real (CCR) pode ser calculada da seguinte forma:

$$
\mathrm{CCR}=\left(\mathrm{CCF}-\mathrm{FC}_{1}\right)-\ldots . . . \mathrm{FC}_{\mathrm{n}}
$$


Onde FC é um Fator de Correção expresso em porcentagem. Para tanto, a fórmula de cálculo é a seguinte:

$$
\mathrm{CCR}=\mathrm{CCF} \times 100-\mathrm{FC}_{1} / 100 \times 100-\mathrm{FC}_{2} / 100 \times 100-\mathrm{FC}_{\mathrm{n}} / 100
$$

Deve-se notar que cada local avaliado será afetado por um grupo de fatores de correção não necessariamente iguais aos de outros locais. Inundações que podem impedir o acesso a um local podem não afetar outros dentro da mesma área protegida, por exemplo. Os fatores de correção estão intimamente associados às condições e características específicas de cada local. Isso significa que a capacidade de carga de uma área protegida deve ser calculada local a local.

Os fatores de correção são expressos em porcentagem. Para o cálculo da fórmula geral é a seguinte:

$\mathrm{Fc}=\mathrm{Ml} / \mathrm{Mt} \times 100$

Onde:

$\mathrm{Fc}=$ Fator de Correção

$\mathrm{Ml}=$ Magnitude limitante da variável.

Mt = Magnitude total da variável.

Segundo Cordeiro, Körössy e Selva (2013, p. 10)

\begin{abstract}
No entanto, a quantidade máxima de visitantes em uma área também deve levar em consideração as condições operacionais do órgão gestor da mesma. Desta forma, a proposta de Cifuentes et al (1992) é que à Capacidade de Carga Real seja agregada a Capacidade de Manejo (CM) de modo a obter a Capacidade de Carga Efetiva (CCE).
\end{abstract}

\title{
4.4.3 Determinação da Capacidade de Carga Efetiva ou Permissível (CCE)
}

A Capacidade de Carga Efetiva ou Permissível (CCE) é o limite máximo de visitas que pode ser permitido, dada a capacidade de ordená-las e gerenciá-las.

A CCE é obtida comparando a CCR com a Capacidade de Manejo (CM) da Administração da área protegida. É necessário conhecer a capacidade mínima de manipulação essencial e determinar qual porcentagem corresponde à CM existente. A CCE será esse percentual da CCR. 
A Capacidade de Carga Efetiva (CCE) incorpora fatores relativos aos recursos humanos, equipamentos e infraestrutura disponíveis no local para dar suporte à visitação e atingir os objetivos de manejo. Desta forma, ela reduz a Capacidade de Carga Real (CCR) de acordo com a capacidade de manejo local (CIFUENTES et al, 1992). Ela calcula-se da seguinte forma:

\section{$\mathrm{CCE}=\mathrm{CCR} \times \mathrm{CM} / 100$}

Onde:

$\mathrm{CM}=$ Capacidade de manejo da área.

Este número é encontrado por meio da elaboração de duas listagens: uma com os recursos humanos, equipamentos e infraestrutura existentes para dar suporte à visitação, denominada 'capacidade instalada'; e outra com aqueles recursos necessários para melhor atender aos visitantes, denominada 'capacidade adequada' (CIFUENTES et al, 1992).

MITRAUD (2003, p.333) enfatiza que

A Capacidade de Manejo (CM) é encontrada por meio da elaboração de duas listagens: uma em que constem todos os recursos humanos, equipamentos e infraestrutura necessária para o correto cumprimento dos objetivos da área (Capacidade Adequada) e, a seguir, uma listagem contendo os recursos efetivamente disponíveis para tal (Capacidade Instalada) será definida de acordo com a porcentagem da capacidade instalada em relação à capacidade adequada. Os recursos existentes e necessários à gestão da área (Capacidade Instalada) são levantados através de trabalho de campo. Nesta ocasião identificam-se quais são e quantos são os recursos (humanos, estruturais, operacionais e financeiros) dos quais o órgão gestor da área dispõe. Paralelamente, identificam-se quais são e quantos são os recursos necessários à adequada gestão da área. Este balanço entre o que há (Capacidade Instalada) e o que deveria haver (Capacidade Adequada) estabelece a Capacidade de Manejo para cada um dos itens considerados na análise. A Capacidade de Manejo da área será justamente a média das várias capacidades de manejo. Note-se que é possível haver situações nas quais sejam identificados recursos necessários à gestão da área (Capacidade Adequada) e que eles simplesmente não existem. Quando isto acontece, a Capacidade de Manejo do item em questão é considerada nula.

Cordeiro, Körössy e Selva (2013, p. 60) afirmam que: "a Capacidade de Manejo da área em questão será a média das várias capacidades de manejo".

A Capacidade de Manejo (CM) é definida através da fórmula:

$\mathrm{CM}=$ Capacidade Instalada (CI) x Capacidade adequada (CA) x 100 
Todos os cálculos são aplicados em separado, a cada sítio em particular. Conceitualmente não é possível determinar capacidade de carga para toda uma área protegida ou para a soma total dos sítios de visitação porque cada um tem características próprias que determinam as variáveis e os fatores de correções a serem aplicados.

Cordeiro, Körössy e Selva (2013, p. 11) explicam:

\begin{abstract}
A metodologia da Capacidade de Carga de Cifuentes et al (1992) pode ser definida da seguinte forma: através de variáveis como avaliação da área disponível, de fatores relacionados com a visita (tempo de visitação e tempo durante o qual o atrativo permanece aberto à visitação) e do espaço ocupado por cada visitante obtém-se a Capacidade de Carga Física de uma determinada área. A esta primeira aproximação, são aplicados Fatores de Correção que tratam de aspectos relacionados às condicionantes ambientais específicas da área, obtendo-se assim a Capacidade de Carga Real. A esta segunda aproximação, aplica-se uma variável que considera as capacidades operacionais do órgão gestor da área, de modo que se obtém a Capacidade de Carga Efetiva, ou seja, o quanto de visitantes uma área pode efetivamente receber sem que isso signifique a degradação do ambiente ou o prejuízo da qualidade da experiência do visitante. Como observa Siles (2003), via de regra, cada um dos níveis representa uma capacidade corrigida em relação à anterior, por isso a CCF será sempre maior do que a CCR, que por sua vez poderá ser maior ou igual à $\mathrm{CCE}(\mathrm{CCF}>\mathrm{CCR} \geq \mathrm{CCE})$.
\end{abstract}

Para Cifuentes et al., (1990, p. 29. Tradução nossa), capacidade de carga efetiva ou permissível é aquela alcançada pela comparação da capacidade real com a capacidade de gerenciamento da administração da área. Esta capacidade de gestão é determinada pela disponibilidade de pessoal, equipamentos, instalações e recursos financeiros de carga efetiva que, em qualquer caso (mesmo excedendo a capacidade ótima de manuseio) pode ser maior que a capacidade real.

“Também foi preferível usar o conceito de visitas / tempo, pois é isso que permite tomar decisões de manejos diferenciadas e aplicáveis a cada sítio" (CIFUENTES et al., 1990, p. 27, tradução nossa).

Segindo Cifuentes et al. (1992, tradução nossa), para definir cada nível de capacidade de carga, as variáveis ambientais, físicas, ecológicas e de manejo do local precisam ser consideradas. Neste sentido, são aplicados fatores de correção aos quantitativos de visitantes identificados no cálculo da capacidade de carga física. Deste modo obtém-se a capacidade de carga real. Os fatores de correção não são sempre os mesmos para todos os locais, visto que dependem das particularidades da área em questão (CIFUENTES et al., 1992). Assim, por exemplo, determinado local pode conter dez fatores de correção enquanto outros podem conter dois ou três. Todos os cálculos foram aplicados separadamente a cada sítio específico. Conceitualmente, não é possível determinar a capacidade de carga para uma área protegida 
inteira ou para a soma total dos locais de visita, pois cada uma possui características específicas que determinam as variáveis ou fatores de correção a serem aplicados. No caso em tela, foram utilizadas as variáveis indicadas na tabela 1.

Tabela 1 - Variáveis usadas para determinar a capacidade de carga.

\begin{tabular}{llcc}
\multicolumn{1}{c}{ CAPACIDADE DE CARGA } & & CAPACIDADE DE & CAPACIDADE DE CARGA \\
\multicolumn{1}{c}{ FICA } & & CARGA REAL & EFETIVA \\
\hline Espaço físico de cada sítio & a. & VARIÁVEIS AMBIENTAIS: & Capacidade de Manejo: \\
relacionado ao espaço que & - seca & - recursos humanos \\
ocupa uma pessoa & b. & VARIÁVEIS FÍSICAS: & - equipamentos \\
normalmente, em um & & - & \\
determinado tempo. & c. & VARIÁVEIS ECOLOGICAS: & \\
& & - & \\
& d. & VARIÁVEIS DE MANEJO: & \\
& & - &
\end{tabular}

Fonte: Cifuentes et al., 1990.

O modelo desenvolvido por Cifuentes (1992, grifo nosso) apresenta seis etapas e considera a capacidade de carga em três níveis como já exposto acima: i) capacidade de carga física, é a simples relação entre espaço disponível e a necessidade de espaço por visitante; ii) capacidade de carga real, aplica-se a capacidade de carga física fatores de correção específicos de cada atrativo turístico e obtidos levando em consideração as variáveis físicas, biológicas e sociais; e, iii) capacidade de carga efetiva ou permissível, considera o Limite Aceitável de Uso (LAU) como uma estimativa da capacidade de manejo da administração do empreendimento, considerando as variáveis como recursos humanos, infraestrutura e equipamentos.

\subsubsection{Limite Aceitável de Uso - LAU}

O Limite Aceitável de Uso é um conceito produzido por Cifuentes (1992) como uma forma de garantir a mínima degradação dos recursos utilizados para os quais existe capacidade de controle e ordenação. Deste modo, podem ser tomadas medidas de manejo que aumentem a capacidade de carga efetiva ou permissível, aproximando-a da capacidade de carga real, mas esses níveis nunca deverão ser ultrapassados.

\subsection{CAPACIDADE DE RENOVAÇÃO DO ESTOQUE PESQUEIRO}

Para estimar o tamanho atual, a taxa de explotação e a produtividade potencial de um estoque de peixes, essa estimação recebe o nome de avaliação do estoque pesqueiro. Esta avaliação tem como objetivo principal prover aconselhamento técnico para manter a 
produtividade do estoque de peixes e manejar a pesca para capturas, tão próximas quanto possível, da produção máxima sustentável (MATEUS; PENHA, 2007).

Mateus e Penha (2007, p. 144) definem Pontos de Referências Biológicos (PRB) como

No contexto da avaliação de estoques, podem ser definidos como um valor convencional derivado de uma técnica de análise, o qual representa o estado de estoque ou população, e cujas características acredita-se ser útil para o manejo de estoque (CADDY \& MAHON, 1995). Assim pontos de referência biológicos são níveis com os quais o atual estado de estoque pode ser medido (COLLIE \& GISLASON, 2001). Em termos práticos são, frequentemente, valores arbitrários e muitas vezes especificados sem variância.

A influência das unidades de conservação: PARNA Serra da Mocidade e ESEC Niquiá na dinâmica do recurso aquático explorado, o Rio Água Boa do Univini é fundamental conceituar o "manancial”. De acordo com Sparre e Venema (1997) manancial é o subconjunto de uma espécie que possui os mesmos parâmetros de crescimento e mortalidade, e que habita uma área geográfica particular. Um manancial tem como características essenciais os parâmetros de crescimento e mortalidade constante ao longo de sua área de distribuição. Nos modelos estruturais de idade é o conceito de coorte, isto é, coorte é um grupo de peixes todos da mesma idade, pertencendo ao mesmo manancial. Existem dois elementos principais na dinâmica de uma coorte: i) o crescimento médio do corpo em comprimento e peso; e, ii) a mortalidade.

Um dos principais focos da gestão pesqueira eficiente é a produção de conhecimento sobre a dinâmica dos estoques alvo e de seus ecossistemas. Portanto, informações são necessárias sobre o que e quanto está sendo capturado (dados de desembarque) e também sobre a biologia e ecologia das principais espécies alvo (PHILIPPSEN, 2017).

Ainda de acordo com Philippsen (2017), na avaliação de estoques pesqueiros têm sido utilizados modelos uni-específicos, e as ações de manejo são tomadas unicamente em relação às populações dos estoques alvo da pesca. Porém, nos últimos anos, abordagens novas passaram a incluir dois pontos fundamentais: i) a valorização do conhecimento do pescador sobre os recursos que ele explora; e, ii) o conhecimento e proteção do ecossistema (incluindo espécies não-alvo da pesca).

Fhilippsen (2017, p. 14) destaca que:

A atividade pesqueira é sustentável se os ecossistemas aquáticos, incluindo suas funções e serviços, persistirem em longo prazo (Arlinghaus et al., 2002). Assim, a preocupação com os impactos diretos, indiretos e cumulativos da pesca comercial no ecossistema não pode ser negligenciada (Fluharty, 2000; Zhou et al., 2010), e a gestão da pesca que foca apenas na maximização da captura de uma espécie alvo, ignorando as relações ecológicas entre os componentes do ecossistema, tende a ser limitada (Pikitch et al., 2004). Nesse sentido, cada vez mais tem sido discutida a abordagem ecossistêmica da gestão de recursos naturais, que envolve diferentes 
dimensões (institucional, humana e ecológica). Assim, quando se dá ênfase à perspectiva pesqueira ou a uma visão holística do ecossistema, denominase de gestão da pesca baseada no ecossistema ("ecosystem-based fisheries management" EBFM) (FAO, 2003; Pikitch et al., 2004). O objetivo geral de uma EBFM é manter os ecossistemas saudáveis, como também a pesca que eles suportam (Cury et al., 2005). Esta abordagem vem sendo usada para complementar, e não substituir, as avaliações baseadas em modelos uni-específicos (Coll et al., 2009; Gascuel et al., 2016).

Segundo Silva Júnior et al (2017, grifo nosso), os estoques pesqueiros são analisados de acordo com sua estrutura etária, a dinâmica de suas coortes e o estabelecimento da relação entre o recrutamento, o tamanho do estoque e a captura em peso. Entender a relação entre o volume da captura e o tamanho do estoque é essencial para deduzir os níveis de exploração de uma pescaria.

Em se tratando de área restrita, os peixes esportivos possíveis de serem capturados na área não têm renovação frequente na sua população. Embora haja indícios, não é comprovada a entrada de novos cardumes de peixes grandes para repor a baixa nos estoques ocasionada pelas pescas de subsistência, amadora ou comercial no Rio Água Boa do Univini.

\subsubsection{Influência da unidade de conservação no estoque pesqueiro}

A superfície territrorial do Estado de Roraima é de $225.116,1 \mathrm{Km}^{2}$, aproximadamente $37.253,52 \mathrm{Km}^{2}$ estão sob proteção como unidades de conservação, isto equivale a $16,55 \%$ da área do território do Estado cuja distribuição pode ser visualizada na tabela abaixo (RUSCHAMNN, 2002). 
Tabela 2 - Unidades de conservação e respectivas áreas do Estado de Roraima.

\begin{tabular}{|l|c|}
\hline \multicolumn{1}{|c|}{ Unidades de Conservação } & Área (em ha) \\
\hline PARNA Monte Roraima & $116.000,00$ \\
\hline PARNA Viruá & $227.011,00$ \\
\hline PARNA Serra da Mocidade & $350.960,00$ \\
\hline ESEC Maracá & $101.312,00$ \\
\hline ESEC Caracaraí & $80.560,00$ \\
\hline ESEC Niquiá & $286.600,00$ \\
\hline FLONA Roraima & $143.000,00$ \\
\hline APA Municipal Xeriuini & $1.671 .694,00$ \\
\hline APA Municipal Rio Itapará & $748.051,00$ \\
\hline RPPN Sesc - Tepequém & 54,58 \\
\hline RPPN Mani & $\mathbf{3 . 5 8 2 . 3 5 2 , 1 7}$ \\
\hline \multicolumn{1}{c}{ TOTAL } & \\
\hline
\end{tabular}

Fonte: Ruschamann Consultores, 2002

Com relação à hidrografia da região, o Rio Branco é o principal curso d'água dentro da ESEC Niquiá. Sua bacia domina quase toda a área de Roraima e é na parte baixa do rio que a ESEC Niquiá está inserida. O Rio Água Boa do Univini, um dos principais tributários do Rio Branco, delimita a ESEC Niquá em parte do seu curso.

Segundo o Acordo de Pesca do Baixo Rio Branco a área destinada para a prática da Pesca Esportiva é de 98,9 km, compreendendo esse trecho da foz do Rio Branco até o lago do Capivara, o maior tributário do Rio Água Boa do Univini. Entretanto, a extensão total do Rio Água Boa do Univini, da nascente até a foz com o Rio Branco é de 245,309 km. Essa área já é bastante procurada por pescadores esportivos, por se tratar de um dos melhores locais do Brasil para a pesca do tucunaré.

Segundo o mapa dos lagos, ressacas e igarapés que compõem o Rio Água Boa do Univini, estão assim distribuidos e caracterizados conforme o Acordo de Pesca do Baixo Rio Branco (Figura 15):

Lado Direito: rio Capivara (não reaiza a prática da pesca esportiva, limite com as unidades de conservação: PARNA Serra da Mocidade e ESEC Niquiá), lago do Poção, lago do Zito, ressaca do Serrinha, ressaca do Camalião, lago do Castanho, ressaca do Castanho, Igarapé do campos (não pratica a pesca esportiva, devido ser muito estreito e água limpa e transparente), lago do Bacuri, ressaca do Bacuri, lago do Furo, lago do Cobra, ressaca do 
Cobra, lago do Mendonça, igarapé do Butelho, ressaca do Tapajós, ressaca do Piritu, lago ou ressaca Camuri e lago ou ressaca do Boca.

Lado Esquerdo: (não realiza a prática da pesca esportiva, área da ESEC Niquiá: lago e ressaca), ressaca do Arraial, lago do Peixe Boi, lago do Cigano, ressaca do Sapo, igarapé do Comandá, ressaca do Pato, igarapé do Aniquiá (limite da ESEC Niquiá, a partir pesca do lado direito e esquerdo do Rio Água Boa do Univini), ressaca do Pacará, ressaca do Sovinha, lago do Forquilha, lago do Pedro, lago do Butelhão (dois lagos conectados), ressaca do Boiaçú, lago da Praia e ressaca do Pão-de-Açúcar.

Figura 15 - Composição dos lagos e ressacas do Rio Água Boa do Univini.

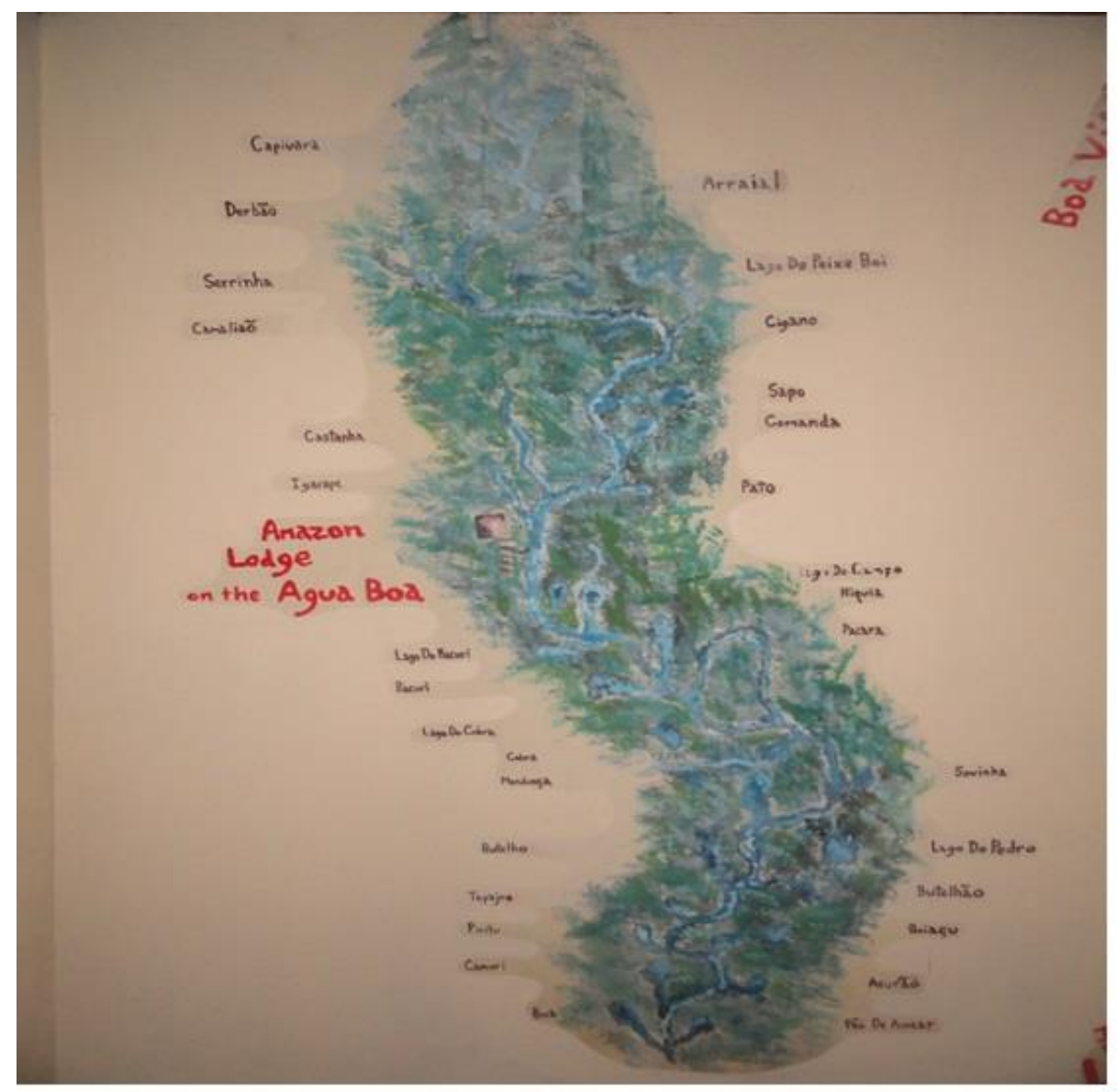

Fonte: Água Boa Amazon Lodge, 2019.

As águas do Rio Água Boa do Univini são classificadas como água pretas, sendo considerado um rio raso, conforme tabela 3. No período seco seu leito forma uma infinidade de meandros, muitas vezes impedindo a passagem de barcos de pesca. Por outro lado, no período chuvoso suas margens inundam, formando uma extensa área alagada. O igarapé Aniquiá, que percorre por toda a extensão da ESEC Niquiá, é formado de águas pretas, assim como o Rio Água Boa do Univini. A cor preta da água é definida pela alta concentração de 
ácidos húmicos e fúlvicos dissolvidos nesses recursos hídricos que drenam solos muito arenosos e de alta permeabilidade. A ESEC Niquá tem vários lagos, ressacas e igarapés no seu interior de grande importância para a manutenção e conservação da ictiofauna do local.

Tabela 3 - Localização, dimensão e profundidade média dos corpos d'água do Rio Água Boa do Univini, no período de outubro de 2018 a março de 2019. Roraima, Brasil.

\begin{tabular}{|c|c|c|}
\hline Localização & $\begin{array}{c}\text { Dimensão* } \\
\mathrm{G}:>50.000 \mathrm{~m}^{2} \\
\mathrm{M}: 30-50.000 \mathrm{~m}^{2} \\
\mathrm{P}:<30.000 \mathrm{~m}^{2}\end{array}$ & $\begin{array}{l}\text { Profundidade Média } \\
\text { (Metros) }\end{array}$ \\
\hline \multicolumn{3}{|c|}{$\begin{array}{l}\text { Rio Capivara (Limite das UCs - PARNA Serra da Mocidade e ESEC Niquiá com a área destinada à } \\
\text { pesca esportiva). }\end{array}$} \\
\hline \multicolumn{3}{|c|}{ Lado Direito - do rio Capivara até Igarapé Aniquiá } \\
\hline Zito (lago) & Pequeno & 4 \\
\hline Porção (lago) & Pequeno & 2 \\
\hline Serrinha (ressaca) & Pequeno & 2 \\
\hline Canela da Avó (ressaca) & Pequeno & 1 \\
\hline Camaleão (ressaca) & Pequeno & 2 \\
\hline Castanho (lago) & Grande & 4 \\
\hline Castanho (ressaca) & Grande & 4 \\
\hline Igarapé Aniquiá (Limite da reserva) & Grande & 4 \\
\hline \multicolumn{3}{|c|}{ Abaixo do Igarapé Aniquiá - Lado Direito } \\
\hline Bacuri (lago) & Médio & 3 \\
\hline Bacuri (ressaca) & Médio & 3 \\
\hline Furo (lago) & Pequeno & 2 \\
\hline Cobra (lago) & Médio & 3 \\
\hline Cobra (ressaca) & Médio & 3 \\
\hline Braulino (lago) & Pequeno & 3 \\
\hline Mendonça (lago) & Grande & 4 \\
\hline Butelho (ressaca) & Pequeno & 2 \\
\hline Tapajós (resseca) & Pequeno & 3 \\
\hline Piritu (ressaca) & Médio & 3 \\
\hline Bodó (ressaca) & Médio & 3 \\
\hline Bodó (lago) & Médio & 2 \\
\hline \multicolumn{3}{|c|}{ Abaixo do Igarapé Aniquiá - Lado Esquerdo } \\
\hline Sovinha (ressaca) & Pequeno & 1 \\
\hline Pacará (ressaca) & Pequeno & 2 \\
\hline Ademarzinho (lago) & Pequeno & 3 \\
\hline Butelho (lago) & Grande & 4 \\
\hline Peixe - Boi (lago) & Médio & 3 \\
\hline Forquilha (lago) & Médio & 3 \\
\hline Maria Pinto (lago) & Médio & 3 \\
\hline Boiaçu (ressaca) & Médio & 4 \\
\hline Acurão (ressaca) & Pequeno & 3 \\
\hline Jandaíra (lago) & Médio & 3 \\
\hline Pão de Açúcar (ressaca) & Médio & 3 \\
\hline
\end{tabular}




\section{RESULTADOS}

\subsection{CAPACIDADE DE CARGA RECREATIVA DAS EMBARCAÇÕES DE PESCA ESPORTIVA NO RIO ÁGUA BOA DO UNIVINI}

A capacidade de carga é um dos fatores mais importantes para se definir o potencial de determinada área para a prática da pesca esportiva. Trata-se da definição de quantos pescadores esportivos podem praticar a pesca no rio ao mesmo tempo, sem prejudicar a atividade para não causar estresse aos peixes ou desconforto aos próprios turistas.

Definida a área de estudo e o modelo teórico a ser utilizado no cálculo da capacidade de carga, neste caso, utilizada a Metodologia de Cifuentes et al. (1992), adaptada para as condições de água interior, no caso em tela, o Rio Água Boa do Univini procede-se, a partir de agora, a sua estimação.

A capacidade de carga da pesca esportiva embarcada praticada no Rio Água Boa do Univini foi calculada da seguinte maneira:

\subsubsection{Capacidade de Carga Física (CCF)}

De acordo com Cifuentes et al. (1992), onde empregou-se a metodologia para o cálculo da Capacidade de Carga Física (CCF) a partir do método proposto, utiliza dados relativos à área total de visitação $(\mathrm{S})$; área ocupada por um visitante (V/a); tempo total em que a área está aberta $(\mathrm{T})$ e tempo necessário para visitar o local (t).

Na área em estudo, o Rio Água Boa do Univini, definidos os critérios básicos:

- Área total de visitação (S) classificação do uso do Rio Água Boa do Univini, para a pesca esportiva embarcada, definida a partir da recomendação da Instrução Normativa $\mathrm{N}^{\circ} 180$ de 09 de julho de 2008, que estabelece no Acordo de Pesca do Baixo Rio Branco que a área de pesca esportiva fica compreendida da Calha do rio, do Estirão do Mendonça até a Foz do Rio Capivara, maior tributário do Rio Água Boa do Univini. A área destinada à pesca esportiva georreferenciada foi é de $98,8 \mathrm{~km}$ ao longo do leito do rio; com relação à largura varia de 40 a 60 metros. Com esses valores foi possível determinar a área superficial do Rio Água Boa do Univini em cinco mil e novecentos e vinte e oito $\left(5.928 \mathrm{~m}^{2}\right)$ metros quadrados; 
- Na metodologia de Cifuentes et al. (1992), para cálculo da área ocupada por visitante, utiliza-se $1 \mathrm{~m}^{2}$ de espaço para a pessoa mover-se livremente, no caso em tela, por se tratar de pesca esportiva embarcada, o mais correto é trabalhar com a área ocupada pelo barco. Segundo Ruschmann, Paolucci e Maciel (2008); Cordeiro, Körösy, Selva (2013) é crítico para a determinação da capacidade de carga, já que reflete o nível de uso considerado mais adequado para os recursos em questão, e um julgamento subjetivo da qualidade da experiência do pescador esportivo.

No presente estudo, os barcos foram medidos para fins dos cálculos do autor, sendo o tamanho do barco utilizado no Água Boa Amazon Lodge de 7, $63 \mathrm{~m}^{2}$, enquanto na Porto Tur - Pesca Esportiva é de 7,2 $\mathrm{m}^{2}$, haja vista que houve uma pequena diferença no tamanho dos botes empregados em cada empreendimento, o autor optou pelo uso do barco com maior comprimento, ficando para fins de cálculo, $7,63 \mathrm{~m}^{2} /$ barco utilizado na pesca esportiva. Sobre esse tema, a literatura cita as medidas utilizadas nas diversas embarcações, a respeito do fator relativo à área ocupada por um visitante,

- Com relação às variáveis $(\mathrm{T})$ "tempo total em que a área está aberta à visitação" e (t.v.) "tempo necessário para visitar o local”, não foi considerado nesse estudo, por não se adequar às atividades de pesca dos empreendimentos estudados, os mesmos não adotam nenhuma normativa que estipule o horário em que a área deve ficar aberta à pescaria, porém, nos dois empreendimentos não ocorre a pesca esportiva à noite. Para Ruschmann, Paolucci e Maciel (2008); Cordeiro, Körösy, Selva (2013), de modo geral, estes fatores são válidos sobretudo para aplicação em trilhas e outros atrativos que pressupõem um roteiro determinado de visitação, vários grupos de visitantes em períodos de tempo sucessivos, e ingresso controlado. No caso do rio, o que se verifica, em geral, é um tempo muito maior de permanência, o que não justifica a aplicação do fator tempo. No Água Boa Amazon Lodge o turista sai por volta das 7 horas, passa o dia pescando, realiza a própria refeição no rio e retorna às 17 horas para o hotel, por outro lado, os pescadores da Porto Tur Pesca Esportiva, saem às 7 horas para pescar, retornam ao meio-dia para o almoço, saem do barco hotel às 14 horas para a pesca e retornam às 18 horas para o barco hotel. Isso reflete o número máximo de pescadores esportivos que o rio pode receber em um dado momento e não em um período de tempo determinado. Além do mais, o propósito do estudo é estimar o quantitativo máximo de embarcações que a área pode receber em simultâneo, e não ao longo do dia. 
Deste modo, para a determinação da Capacidade de Carga Física das embarcações motorizadas utilizadas para pesca esportiva no Rio Água Boa do Univini, empregou-se a seguinte fórmula:

\section{$\mathrm{CCF}=\mathrm{V} / \mathrm{a} \times \mathrm{S}$}

Onde:

$\mathrm{S}=5.928 \mathrm{~m}^{2}$ (Tamanho da área definida para o turismo da pesca esportiva),

$\mathrm{V} / \mathrm{a}=7,63 \mathrm{~m}^{2}$ (dimensões do barco de pesca, sendo dois pescadores esportivos por barco).

$$
\mathrm{CCF}=5.928 \mathrm{~m}^{2} \times 7,63 \mathrm{~m}^{2}
$$

\section{$C C F=45$ barcos motorizados para pesca esportiva}

Importante mencionar que este valor se refere ao número máximo recomendado de embarcações que podem ser utilizadas no Rio Água Boa do Univini, simultaneamente nos dois empreendimentos que operam nesse rio.

\subsubsection{Capacidade de Carga Real (CCR)}

Ainda de acordo com Cifuentes et al. (1992), o limite máximo de embarcações transitando no Rio Água Boa do Univini é determinado a partir do cálculo da Capacidade de Carga Física (CCF), incorporando os fatores de correção definidos em função das características particulares do Rio Água Boa do Univini. Esses fatores de correção obtêm-se considerando as variáveis físicas, ambientais, ecológicas, sociais e de manejo do Rio Água Boa do Univini, na região do baixo Rio Branco.

Os fatores de correção considerados na área de estudo para o cálculo da Capacidade de Carga Real (CCR): seca $\left(\mathrm{FC}_{1}\right)$ e qualidade da experiência vivenciada pelo pescador esportivo $\left(\mathrm{FC}_{2}\right)$.

De acordo com Junk et al. (1989), o pulso de inundação observado nas cabeceiras dos grandes rios da Amazônia resulta do somatório de toda a bacia de drenagem e do degelo anual andino. É a força motriz que determina os processos nas áreas alagáveis, controlando ciclos biogeoquímicos, ritmos de crescimento e ciclos de vida da biota e atividades das populações humanas. Além disso, as incertezas associadas ao ciclo hidrológico, como data e início e término da época de águas baixas, duração deste período e intensidade da seca, influenciam os 
resultados da pescaria e podem constituir elementos de satisfação ou de desapontamento para turistas que vêm de outros locais (estados do Brasil ou do exterior), com custos elevados, para pescar na Amazônia (SOUZA et al., 2015). Essa fase do pulso de inundação, caracterizada como a seca do rio, pode ser um fator que limita a pescaria na medida em que se considera que o volume pluviométrico é baixo, afetando a navegabilidade no rio por causa do aparecimento de bancos de areia, apresentado em vários trechos do rio e uma profundidade média em torno de 5 a 10 centímetros.

Com relação ao excesso de barcos com seus respectivos pescadores, também é um fator limitante, porque os vários deslocamentos no rio e barulhos excessivos dos motores podem ter um impacto negativo sobre espécies de peixes. Dias Neto (2015) ressalta que muitos pescadores atribuem ao ruído dos motores das embarcações em trânsito pela Lagoa Feia em Ponta Grossa dos Fidalgos, RJ, como uma desvantagem, sendo perceptível diminuição da quantidade de pescado nos últimos anos. "É como se espantasse os peixes", dizem, pois argumentam que os peixes, ao se esconderem na vegetação e nos brejos, são mais difíceis de serem capturados. No manejo da área de pesca esportiva os guias de pesca revezam essas áreas, por no mínimo 02 (dois) dias, visando à recuperação de piscosidade da área em observância à memória do peixe que se refere ao tempo gasto para determinada espécie voltar à atividade normal após a movimentação na área, considerando fisgados, peixes embarcados e liberados, barulho, enfim, qualquer modificação nas condições naturais que possam contribuir para alguma forma de estresse nos peixes (PORTARIA No 001/2011- FEMARH).

Os fatores de correção ou limitante determinado para o Rio Água Boa do Univini, na região do baixo Rio Branco foi o seguintes: $\mathrm{FC}_{1}$ - período de seca e $\mathrm{FC}_{2}$ - qualidade da experiência do pescador esportivo.

Fator de Correção Período Seco (FC1): De acordo com a Classificação Climática de Köppen-Geiger (2007), mais conhecida como Classificação climática de Köppen, é o sistema de classificação global dos tipos climáticos mais utilizados em Geografia, Climatologia e Ecologia. Essa classificação baseia-se na fitossociologia e na ecologia da vegetação natural e expressa o clima prevalecente na região.

A estação seca no Estado de Roraima inicia-se em outubro e estende-se até março. Para o cálculo do Fator de Correção referente ao período seco $\left(\mathrm{FC}_{1}\right)$, considerou-se o período tradicionalmente seco na região: outubro a março (ANDRETTA, 2006). Assim, para o período seco $\left(\mathrm{FC}_{1}\right)$ tem-se: 


$$
\begin{aligned}
& \mathrm{Ml}=182 \text { dias (outubro a março) } \\
& \mathrm{Mt}=365 \text { dias por ano } \\
& \text { Aplicando a fórmula: } \\
& \mathrm{FC}_{1}=\mathrm{Ml} / \mathrm{Mt} \times 100 \\
& \boldsymbol{F C}_{\boldsymbol{I}}:(182 / 365) \times 100 \\
& \boldsymbol{F C}_{\boldsymbol{I}}=50 \%
\end{aligned}
$$

Neste período, o Rio Branco sobe entre 6 a 8 metros na cidade de Caracaraí, e 8 a 12 metros em Santa Maria do Boiaçú, com vazões variando entre 8.000 a $13.000 \mathrm{~m}^{3} / \mathrm{s}$. Em média o Rio Branco transporta aproximadamente $45 \mathrm{mg} / \mathrm{l}$ de sedimentos em suspensão, com mínimos na estiagem com cerca de 10 a $20 \mathrm{mg} / \mathrm{l}$ e picos na cheia de 70 a $80 \mathrm{mg} / \mathrm{l}$, caracterizando este rio não somente como de água branca típico, mas um padrão misto de água clara e branca. Com relação ao pulso de inundação, este ocorre uma vez ao ano (monomodal) em que as águas acima de 5 metros permanecem cerca de 82 dias, sendo a referência a régua de Caracaraí. Filho, Andretta e Nogeira (2005) afirmam que nos meses de seca, de janeiro a março, período mais seco do rio, dificulta a navegabilidade devido ao surgimento de bancos de areias, aliado ao baixo nível do rio.

\section{Fator de Correção Qualidade da Experiência Vivenciada pelo Pescador Esportivo $\left(\mathrm{FC}_{2}\right)$ :}

$\mathrm{O}$ fator de correção relativo à qualidade da experiência da visitação $\left(\mathrm{FC}_{2}\right)$ é uma variável que busca incorporar no cálculo da capacidade de carga a preocupação com a dimensão psicológica dos pescadores. Parte do princípio de que a experiência do visitante tende a diminuir caso os grupos que visitam uma determinada área estejam muito próximos uns dos outros. Do ponto de vista prático, esta variável considera a área não utilizada entre os grupos de modo que as atividades de um não interfiram na experiência do outro e vice-versa.

No caso em tela, considerou-se que o espaço necessário para um barco não interferir com a experiência do outro poderia ser dada pela distância de segurança. O manual Boating Handbook (2017) define distância de segurança de 30 metros entre embarcações como aquela distância que vai garantir que o barco não irá causar perigo ou dano à outra embarcação. Assim sendo, esses 30 metros é uma distância adequada para que a experiência de um barco 
com dois pescadores não interfira com a de outros barcos de pescadores, esta área deixada livre pode ser calculada, utilizando o cálculo do comprimento da circunferência na qual uma embarcação está no centro e, em sua volta, existe um espaço de 30 metros sem outra embarcação, isto é, cada barco ocuparia uma área circular cujo raio seria de 15 metros (BRASIL ESCOLA, 2019).

Considerando que a área de uma circunferência é dada pela fórmula: $A=4 \pi \mathrm{R}^{2}$, temse que a distância adequada entre os barcos seria: $A=4$ × 3,1416 x 15²; ou seja, $A=2.827,44$ $\mathrm{m}^{2}$.

Assim sendo, a fórmula para calcular a qualidade da experiência vivenciada pelo pescador esportivo $\left(\mathrm{FC}_{2}\right)$ é:

$$
\begin{aligned}
& \mathrm{Ml}=2.827,44 \mathrm{~m}^{2} . \\
& \mathrm{Mt}=5.928 \mathrm{~m}^{2} . \\
& \text { Aplicando a fórmula: } \\
& \mathrm{FC}_{2}=\mathrm{Ml} / \mathrm{Mt} \times 100 \\
& \boldsymbol{F C}_{2}:\left(2.827,44 \mathrm{~m}^{2} / 5.928 \mathrm{~m}^{2}\right) \times 100 \\
& \boldsymbol{F C}_{2}=48 \%
\end{aligned}
$$

Capacidade de Carga Real (CCR) pode ser expressa da seguinte forma:

$\mathrm{CCR}=\mathrm{CCF} \times 100-\mathrm{FC}_{1} / 100$

Aplicando os fatores de correção à fórmula:

$\mathrm{CCR}=45 \times 100-50 / 100 \times 100-48 / 100$

\section{CCR= 12 barcos pescando simultaneamente no Rio Água Boa do Univini.}

Embora, em princípio, outras variáveis fossem consideradas para determinar a capacidade de carga, no momento de fazer os cálculos, elas foram deixadas de lado, como por exemplo, a compactação do solo, erosão como parte das variáveis físicas, e o interesse e preferências dos visitantes no que seriam variáveis sociais. Os fatores de correção não são sempre os mesmos para todos os locais, visto que dependem das particularidades da área em questão (CIFUENTES et al., 1992). Assim, determinado local pode ter seis fatores de correção enquanto outro, três. As correções na capacidade de carga recreativa tendem a garantir a "qualidade" da experiência. 


\subsubsection{Capacidade de Carga Efetiva (CCE)}

\section{$\mathrm{CCE}=\mathrm{CCR} \times \mathrm{CM} / 100$}

A Capacidade de Carga Efetiva ou Permissível (CCE), de acordo com a metodologia de Cifuentes et al. (1992) é o limite máximo de visitas que pode ser permitido, dada a capacidade de ordená-las e gerenciá-las. Na análise da capacidade de carga efetiva, aplica-se sobre a capacidade de carga efetiva um fator de redução derivado de restrições decorrentes de limitações na infraestrutura de recepção e da capacidade de gestão do número de pescadores previsto. Com base no limite estabelecido pela Capacidade de Carga Real (CCR), de 12 barcos pescando simultaneamente no Rio Água Boa do Univini, a Capacidade de Carga Efetiva (CCE) responde se existem condições de receber a quantidade estabelecida. Em outras palavras, o quanto daquele total pode ser visitado com segurança, apoio profissional e qualidade recreativa. Observou-se excelente infraestrutura adequada nos empreendimentos em questão, equipamentos suficientes para dar suporte à visitação, além de instalações sanitárias com fossa séptica, lixo coletado no final do dia de pesca, separado, ensacado e transportado de barco para o município de Caracaraí para reciclagem, conforme figura abaixo, além de palestra no próprio empreendimento sobre programa de Educação Ambiental aos pescadores esportivos, equipamentos de alimentação e hospedagem, entre outros.

Figura 16 - Coleta de lixos nos empreendimentos.
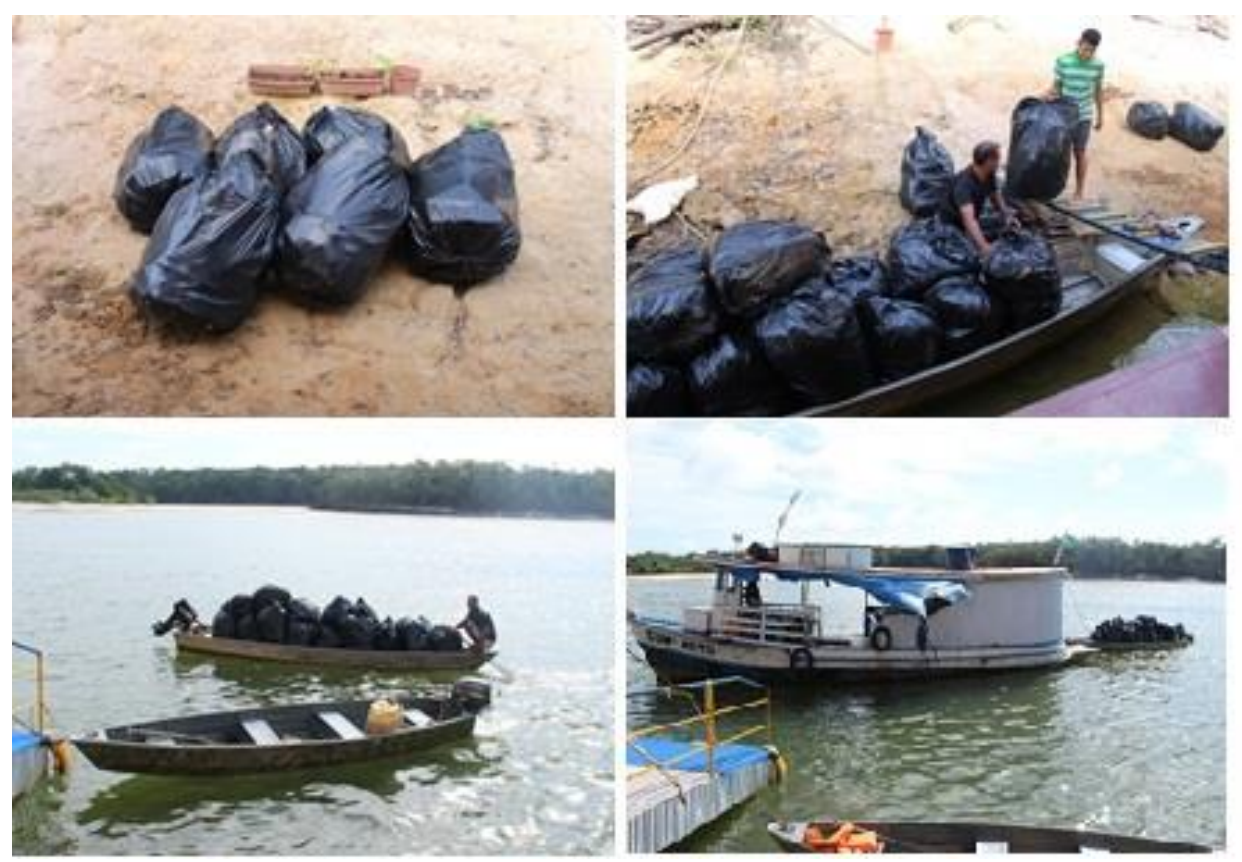

Fonte: O autor, 2019.

A aplicação direta destes critérios no estudo da Capacidade de Manejo (CM) foi estimada com base no que os condutores locais possuíam e o que era desejável para a 
segurança, conforto e melhoria da experiência do pescador esportivo. Assim, foram listados os componentes da capacidade instalada e da capacidade adequada dos operadores de pesca esportiva que atuam no Rio Água Boa do Univini, como pode ser observado nas Tabelas 4 e 5.

Tabela 4 - Descrição geral da Capacidade Instalada (CI) e da Capacidade Adequada (CA) do Água Boa Amazon Lodge que atua no Rio Água Boa do Univini, Roraima, Brasil.

\begin{tabular}{cc}
\hline CAPACIDADE INSTALADA $(\mathrm{CI})$ & CAPACIDADE ADEQUADA (CA) \\
\hline Pessoal $=14$ & Pessoal $=14$ \\
Equipamentos $=14$ & Equipamentos $=14$ \\
Instalações $=14$ & Instalações $=14$ \\
\hline TOTAL $=\mathbf{4 2}$ & TOTAL $=\mathbf{4 2}$ \\
\hline
\end{tabular}

Fonte: O autor, 2018.

Tabela 5 - Descrição geral da Capacidade Instalada (CI) e da Capacidade Adequada (CA) da Porto Tur - Pesca Esportiva que atua no Rio Água Boa do Univini, Roraima, Brasil.

\begin{tabular}{cc}
\hline CAPACIDADE INSTALADA $(\mathrm{CI})$ & CAPACIDADE ADEQUADA $(\mathrm{CA})$ \\
\hline Pessoal $=18$ & Pessoal $=18$ \\
Equipamentos $=10$ & Equipamentos $=10$ \\
Instalações $=18$ & Instalações $=18$ \\
\hline TOTAL $=\mathbf{4 6}$ & TOTAL $=\mathbf{4 6}$
\end{tabular}

Fonte: $\mathrm{O}$ autor, 2018.

Pessoal = São funcionários trabalhando como guias de pesca, cozinheiros (as), garçons e garçonetes, camareiras, serviços gerais e manutenção dando suporte à visitação nos dois empreendimentos localizados no Rio Água Boa do Univini. Para os 12 barcos pescando simultaneamente no rio, definido na Capacidade de Carga Real (CCR), Quanto aos pessoal de apoio nos dois empreendimentos são 32 pessoas, suficientes para atender todas as demandas, durante a temporada de pesca.

Equipamentos $=$ Foram listados barcos, motores a hélice, tipo Mercury de $25 \mathrm{HP}$, motores Turbo, tipo Yamaha 30 HP e motores elétricos de 15 HP Phantom. Quanto aos equipamentos utilizados pelos dois empreendimentos para atendimento de suas clientelas foram 24 motores e barcos, o que garante um excelente trabalho nos períodos de grande fluxo de pesca esportiva (visitação) na temporada de pesca, que ocorre de Outubro a Março. Verificou-se que os empreendimentos têm todos os equipamentos necessários ao bom funcionamento da temporada de pesca esportiva no Rio Água Boa do Univini. 
Instalações = Foi considerada a edificação em terra firme do Água Boa Amazon Lodge (hotel de selva), construído na década de 1990. O hotel está localizado ao longo do Rio Água Boa do Univini em uma região remota do Estado de Roraima, no norte do Brasil. O alojamento está situado em um dos ambientes naturais mais intocados do mundo e goza de proteção permanente contra a pesca comercial ilegal, caça e desmatamento. Com excelentes comodidades, incluindo uma piscina, quartos com ar condicionado, uma sala de recreação e serviço de lavandaria diário e a Plataforma flutuante da Porto Tur - Pesca Esportiva, com toda a estrutura de hotel flutuante, construída recentemente. Em razão disto, entende-se que as duas instalações estão ótimas para atender e receber bem o pescador esportivo, na certeza de que os dias da semana de pesca proporcionarão uma qualidade nas experiências recreativas sustentáveis vividas pelos turistas. Além de diversificada observação da vida selvagem com pássaros.

\subsubsection{Capacidade de manejo}

A Capacidade de Manejo do Água Boa Amazon Lodge e do Barco Hotel Porto Tur Pesca Esportiva, como sendo um reflexo da soma das condições sobre a gestão da área dos empreendimentos, a Capacidade de Manejo é determinada a partir da comparação entre as condições ótimas necessárias à gestão dos empreendimentos (Capacidade Adequada) e as condições existentes (Capacidade Instalada). Uma vez que os fatores apreciados na determinação da Capacidade de Manejo variam consoante as particularidades de gestão de cada área, e considerando que a gestão dos empreendimentos, sendo o primeiro, um hotel de Selva e o segundo um barco hotel, ambos instalados no rio Água Boa do Univini.

Na determinação do nível ótimo da Capacidade Adequada, de acordo com a tabela 6 , foram realizados de forma empírica através de análises in loco onde considerou-se as seguintes variáveis: pessoal, equipamentos e instalações.

Tabela 6 - Capacidade de Manejo dos empreendimentos que operam no Rio Água Boa do Univini, Roraima, Brasil.

\begin{tabular}{lccc}
\hline \multicolumn{1}{c}{ Variável } & $\begin{array}{c}\text { Capacidade } \\
\text { Instalada }\end{array}$ & Capacidade Adequada & $\begin{array}{c}\text { Capacidade de Manejo } \\
(\%)\end{array}$ \\
\hline Pessoal & 32 & 32 & 100 \\
Equipamentos & 24 & 24 & 100 \\
Instalações & 32 & 32 & 100 \\
\hline \multicolumn{2}{c}{ Fonte: 0 autor, 2019. } & & $\mathbf{1 0 0}$ \\
\hline
\end{tabular}

Fonte: O autor, 2019. 
Considerando que a Capacidade de Manejo dos empreendimentos Porto Tur - Pesca Esportiva e Água Boa do Univini foi definida como sendo 100\% da Capacidade de Carga Real por parte dos gestores da área, em termos práticos, atendem otimamente as necessidades dos pescadores esportivos durante a temporada de pesca.

Tem-se, portanto, a Capacidade de Carga Efetiva da Pesca Esportiva no Rio Água Boa do Univini: $\mathbf{C C E}=\mathbf{C C R}=12$ barcos pescando simultaneamente no Rio Água Boa do Univini.

\subsection{IMPACTOS INDIRETOS}

Os impactos indiretos considerados na área de estudo foi a pesca predatória não autorizada, que continua acontecendo por falta de fiscalização. De acordo com Sobreiro e Freitas (2008), o controle e acesso ao recurso e, consequentemente, às formas como os pescadores se apropriam do espaço. Esse conflito está relacionado à restrição ao acesso que as empresas de pesca esportiva fazem aos pescadores artesanais/comerciais na área de estudo. $\mathrm{Na}$ falta de fiscalização das instituições formais para regular o manejo e a fiscalização da pesca, em alguns casos, os operadores de pesca fornecem a logística para que o órgão público responsável realize a fiscalização dessa área. Essa dinâmica conflituosa estão interligados e relacionados a ocupação dos territórios da pesca artesanal/comercial pela mais recente forma de exploração pesqueira, a pesca esportiva. Os conflitos entre as formas distintas lógicas produtivas, onde a mais recente, a cadeia produtiva da pesca esportiva, passa a ocupar territórios construídos anteriormente pela pesca artesanal/comercial, interferindo na reprodução dessa última. Então os danos causados por pesca predatória ou desregrada poderão ser irreversíveis.

\subsection{INFLUÊNCIA DA UNIDADE DE CONSERVAÇÃO}

Para análise da influência do Parque Nacional Serra da Mocidade e Estação Ecológica Niquiá, Unidade de Conservação, regulamentada e categorizada como de Proteção Integral, sobre os estoques pesqueiros no Rio Água Boa do Univini, foram consideradas as pescas experimentais realizadas nas seis zonas de pesca ao longo do trecho de rio, permitido para a prática da pesca esportiva no sistema pesque-e-solte. Avaliou-se também a importância dessas unidades de conservação como fonte de reposição dos estoques de peixes, tais como os Tucunarés: Açú, Paca, Borboleta, Tauá e Amarelo, para a prática da pesca esportiva. 
As espécies de tucunaré açu (Cichla temensis) capturados nas zonas de pesca apresentaram comprimentos variando de 53 a 85 centímetros Observou-se que os peixes capturados na zona 2 apresentaram comprimento padrão em torno de 85 centímetros. Por outro lado, as espécies de tucunaré açú capturados nas zonas 1, 3, 4 e 6 apontaram um comprimento padrão na ordem de 68 a 72 centímetros. Já na zona 5 o crescimento médio dessa espécie acusou o menor comprimento médio de 53 centímetros. Portanto, verifica-se que não há uma relação direta do comprimento do animal com a proximidade da unidade de conservação.

Os dados mostram que as unidades de conservação não exercem uma influência direta no tamanho dos peixes capturados, provavelmente seja devido à insuficiência da intensidade de pesca experimental praticada no experimento, haja visto que os dados mostraram não ter havido a necessidade de recuperação dos estoques, o que aponta que a abundância do recurso pesqueiro ao longo do Rio Água Boa do Univini continua suficiente para a prática de boas pescarias. Essa produtividade relacionada ao tamanho dos exemplares e à quantidade capturada, além do ótimo estado de conservação do local, comprovou-se o baixo impacto ambiental da pesca esportiva como está sendo praticada no Rio Água Boa do Univiní. Ver figura 17.

Figura 17 - Medidas de comprimento de tucunaré açú capturados nas zonas de pesca.

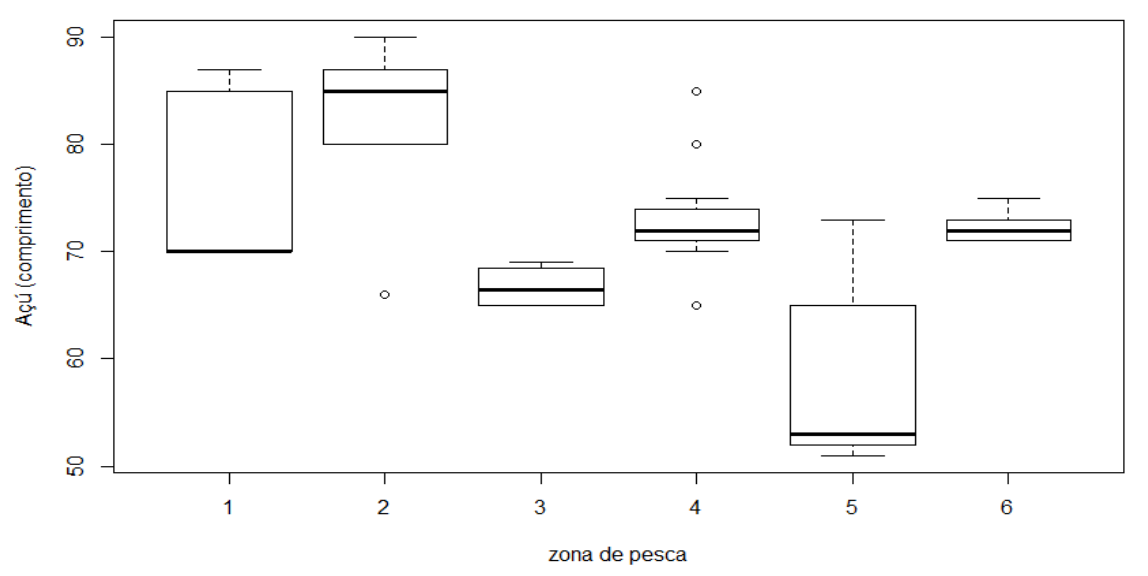

Com relação às espécies de tucunaré paca (Cichla temensis) que apresentam pintas brancas distribuídas regularmente pelo corpo e nadadeiras, caracterizando que a espécie não se encontra no período reprodutivo, observou-se uma variação de tamanho dos peixes entre 35 a 62 centímetros. De acordo com a figura 18, verifica-se que na zona 1, os tucunarés paca apresentaram o maior comprimento padrão, com 62 centímetros. Enquanto os tucunarés paca 
capturados por ocasião da pesca experimental na zona 6 , o comprimento médio dos animais foi de 50 centímetros. Nas zonas 4 e 5, o comprimento médio dos peixes capturados foi de 45 a 48 centímetros. Na zona 2 o comprimento médio das espécies capturadas no momento da pesca foi de 38 centímetros e a zona de pesca 3 apresentou o menor comprimento dentre as espécies capturadas, com 35 centímetros.

Verifica-se que as unidades de conservação novamente não exerceram influência direta no comprimento dos peixes capturados ao longo do rio na extensão destinada à pesca esportiva. O que leva a crer que a prática da pesca esportiva, até o presente momento, tem exercido baixo impacto ambiental sobre o recurso pesqueiro existente no Rio Água Boa do Univini.

Figura 18 - Medidas de comprimento do tucunaré paca nas zonas de pesca.

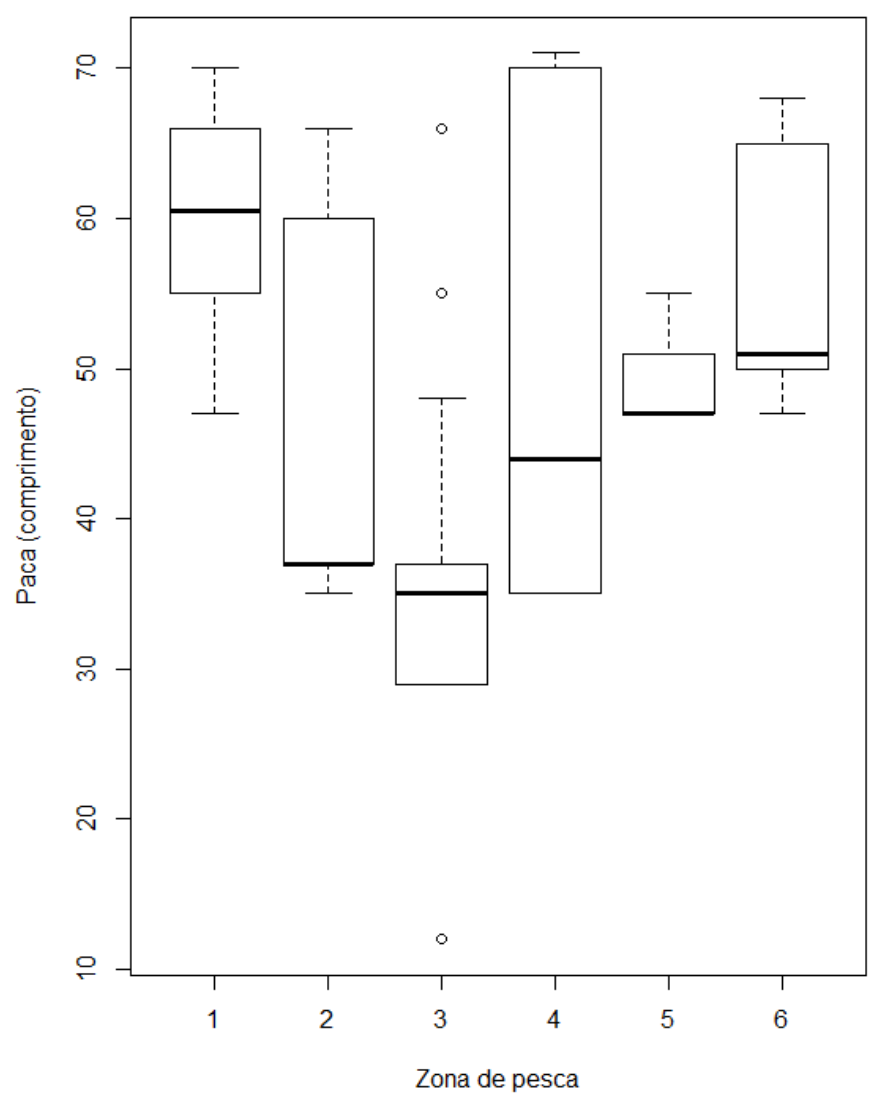

Para as espécies denominadas de tucunaré tauá (Cichla monoculus), nome popular dado a essa espécie pelos pescadores esportivos frequentadores do Rio Água Boa do Univini, também conhecidas nas demais regiões da Amazônia, como tucunaré popoca, apresentou uma grande variação de tamanho, essa variação foi de 10 a 35 centímetros. Observou-se o seguinte 
comportamento desta espécie no momento das capturas: a zona 6 apresentou o maior comprimento médio com 35 centímetros. Em seguida as zonas de pesca 1 e 3, o tamanho médio dos peixes foi de 28 centímetros. Os tucunarés tauá capturados na zona 5, apresentaram um comprimento médio de 15 centímetros. Por último, na zona de pesca 2, os peixes capturados no momento da pesca, apresentaram um comprimento médio de 10 centímetros.

Ressalta-se que, devido à característica biológica desta espécie, eles apresentam o maior comprimento de 40 centímetros, portanto, são peixes de tamanho pequeno (Figura 19).

Figura 19 - Medidas de comprimento de tucunaré tauá capturados nas zonas de pesca.

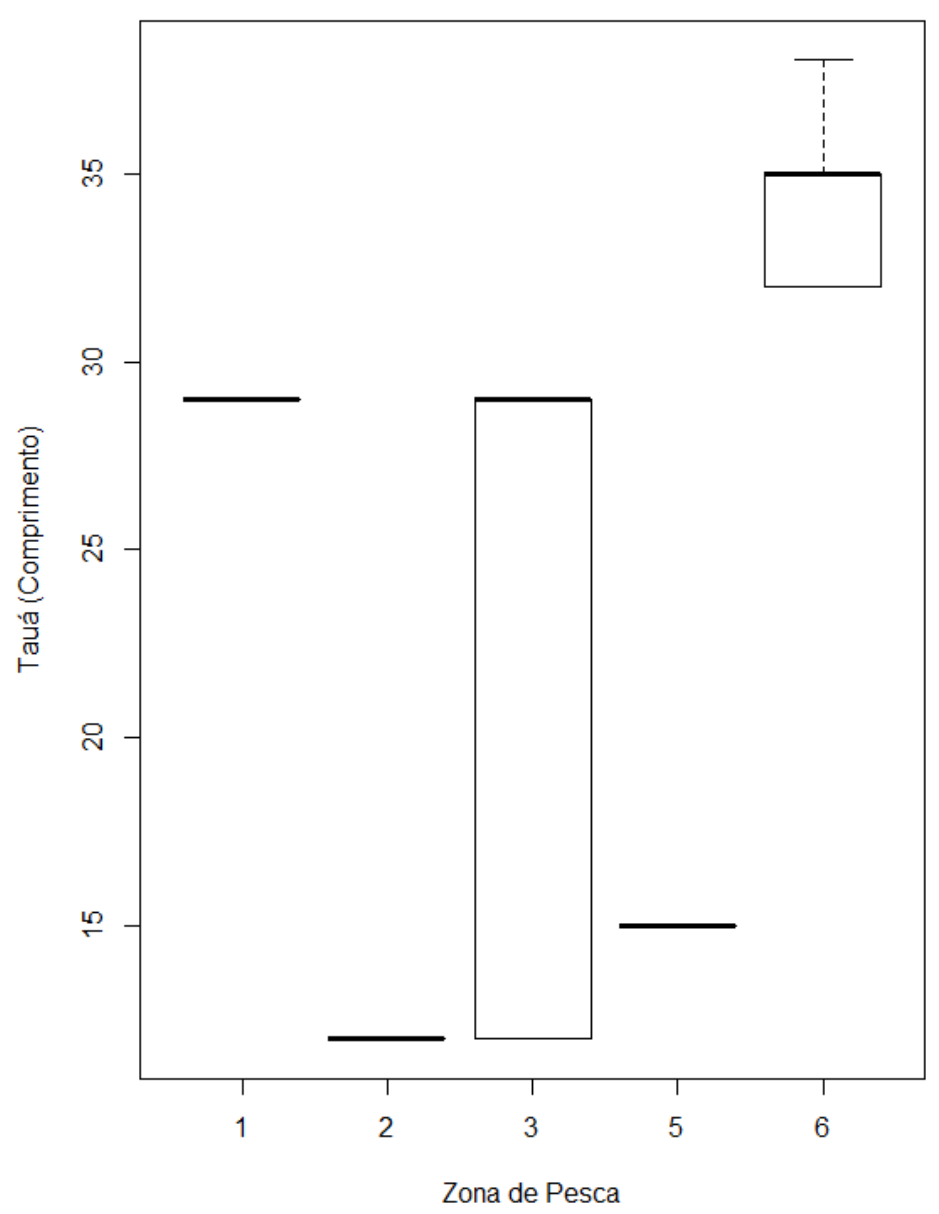

Com relação às espécies de tucunaré borboleta (Cichla orinocensis) capturadas durante as pescas experimentais, houve uma pequena variação entre os comprimentos de 30 a 40 centímetros, apresentando o seguinte quadro: na zona 6, os peixes capturados apresentaram o tamanho médio de 40 centímetros. Na zona 1, o comprimento médio dos peixes fisgados pelos pescadores esportivos foi de 35 centímetros. Entretanto, nas zonas de pesca 2, 3, 4 e 5 
praticamente não houve variação no comprimento dos peixes, que apresentaram um tamanho médio de 30 centímetros.

Com relação às espécies de tucunaré borboleta, pela sua biologia são espécies de tamanho também pequeno, atingindo seu máximo comprimento com 55 centímetros (Figura 20).

Figura 20 - Medidas de comprimento de tucunaré borboleta capturados nas zonas de pesca.

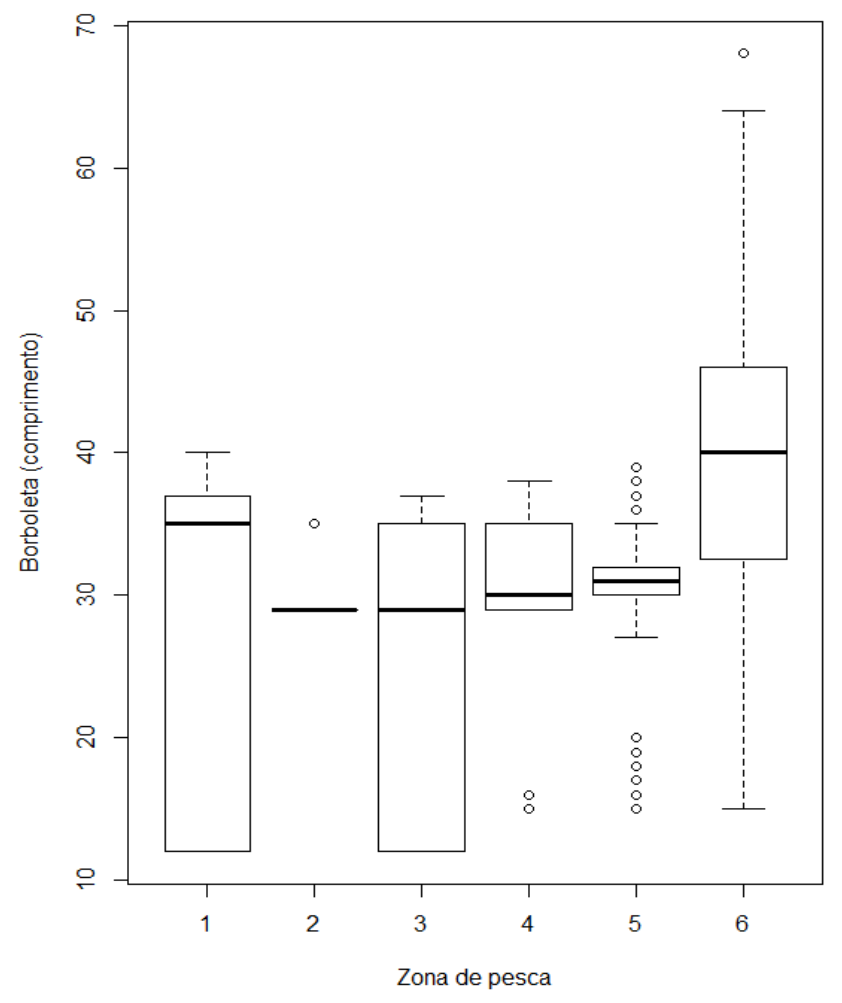

Para as medidas de peso constatadas na pesca zoneada verificou-se que para a espécie denominada tucunaré açu (Cichla temensis) houve uma variação de 3,5 kg a 6,5 kg. A zona 2 apresentou o peixe tucunaré açu com maior peso, cerca de $6,5 \mathrm{~kg}$. Na zona 4 , as medidas de peso médio do tucunaré foram de $5,5 \mathrm{~kg}$; a zona 6 aparece com tucunaré pesando em média $5,0 \mathrm{~kg}$. Já na zona de pesca 1 , os pesos médios dos peixes foram de 4,5 $\mathrm{kg}$. $\mathrm{Na}$ zona 3 , os peixes apresentaram um peso médio de $4,3 \mathrm{~kg}$ e, finalmente, a zona 5 a média de pesos dos peixes foram de $3,5 \mathrm{~kg}$.

Verifica-se que não existe um padrão de peso das áreas de pesca com a influência das unidades de conservação existentes na área de estudo (Figura 21). 
Figura 21 - Medidas de peso de tucunaré açú capturados nas zonas de pesca.

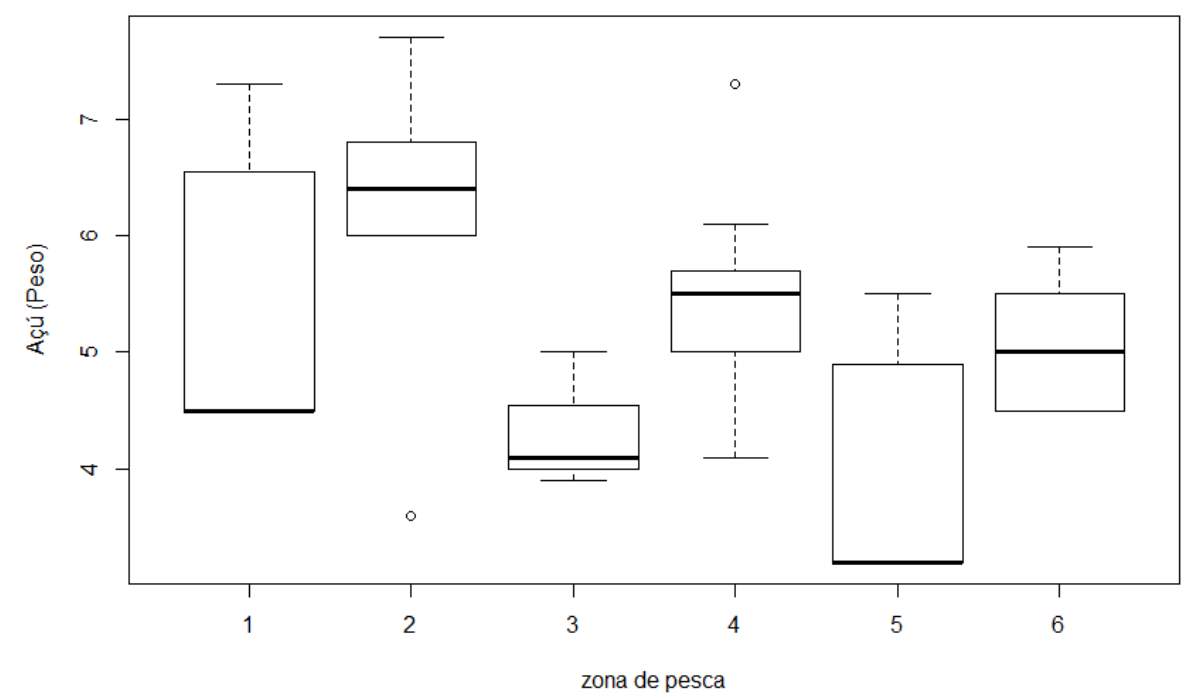

Com relação às medidas de peso determinadas nas 6 áreas de pesca. Verificou-se que a espécie denominada tucunaré paca (Cichla temensis), apresentou uma variação de 2,0 kg a 5,0 $\mathrm{kg}$. Na zona 1 obteve-se as maiores medidas de peso dos animais com 5,0 kg, enquanto na zona 6 o peso médio dos peixes foi de $4,8 \mathrm{~kg}$, já nas zonas 2,4 e 5 os pesos médios dos animais capturados foram de 4,0, 4,3 e 4,5 kg, respectivamente, e, por último, a zona 3 apresentou o menor peso médio dos peixes capturados, com 2,0 kg (Figura 22).

Figura 22 - Medidas de peso de tucunaré paca capturados nas zonas de pesca.

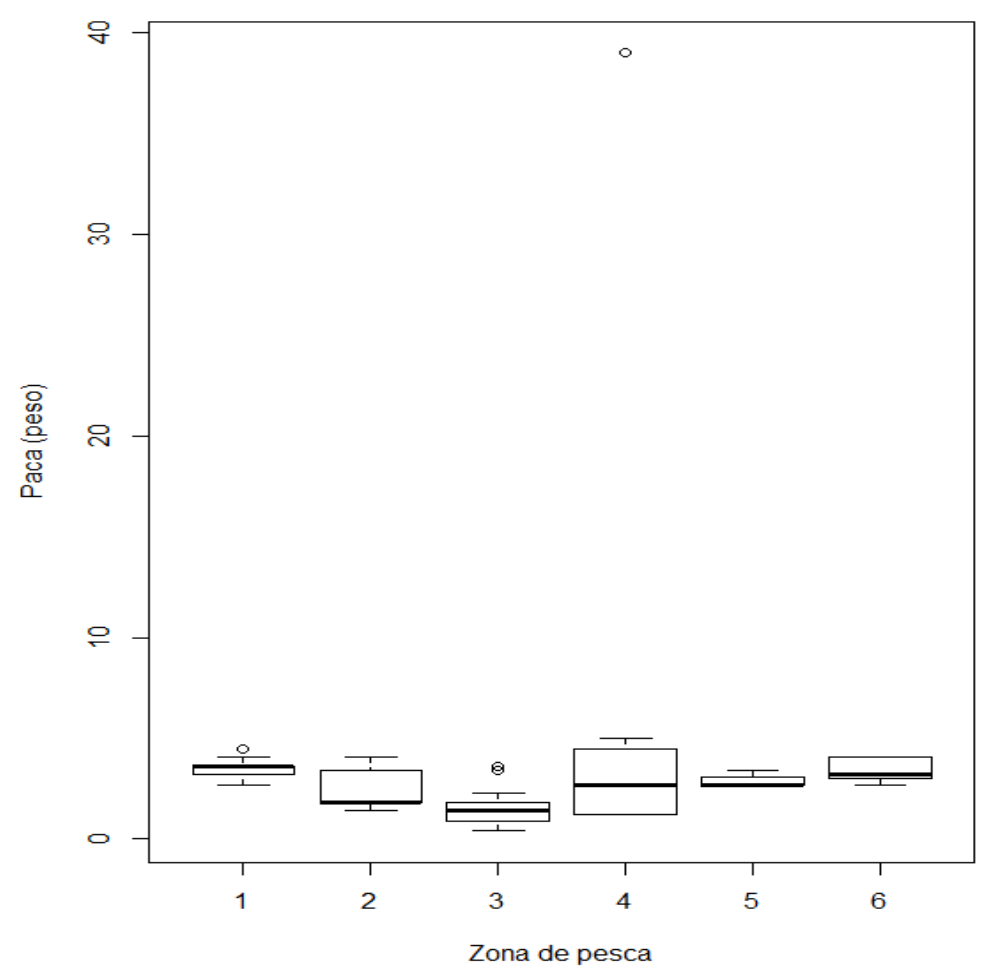


Com relação às medidas de peso determinadas nas zonas de pesca, verificou-se que na espécie denominada tucunaré tauá (Cichla monoculus) ocorreu uma grande variação de $0,4 \mathrm{~kg}$ a 1,8 kg. Observou-se ao longo da temporada de pesca que essa espécie tem tamanho pequeno e, portanto, o peso é proporcional ao seu tamanho. A zona 2 apresentou o menor peso, enquanto a zona 6 o maior peso, por outro lado, as demais zonas apresentaram valores intermediários entre o menor e o maior peso.

Notou-se também quem em relação a essa espécie, nas unidades de conservação: Parque Nacional Serra da Mocidade e Estação Ecológica Niquiá, mesmo sendo unidade de proteção integral, não podendo ser habitadas pelo homem, sendo admitido apenas o uso indireto dos seus recursos naturais, por exemplo, em atividades como pesquisa científica e turismo ecológico, não foi observada a influência direta sobre a população de peixes, tanto no comprimento como também no peso, o que mostra que o Rio Água Boa do Univini é bastante piscoso, e que a pesca esportiva praticada nesse ambiente é de baixo impacto. (Figura 23).

Figura 23 - Medidas de peso de tucunaré tauá capturados nas zonas de pesca.

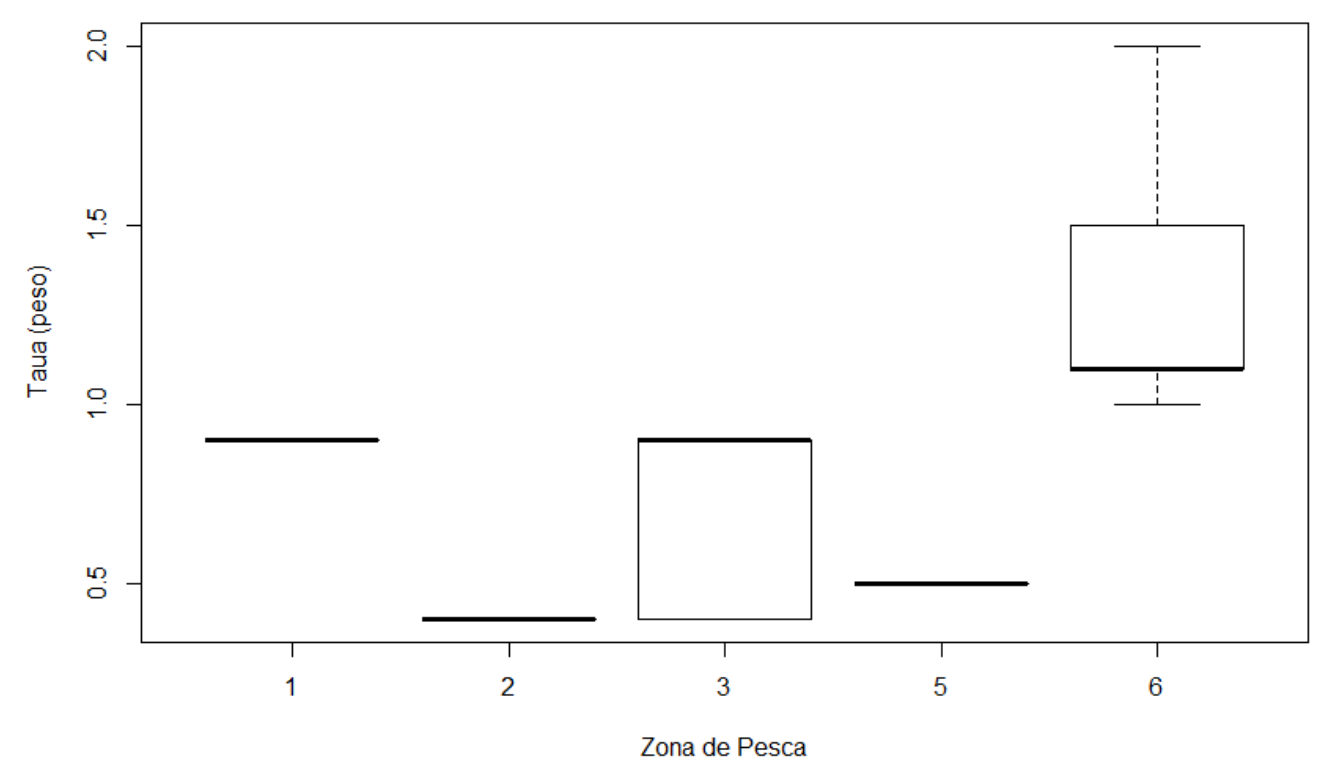

A respeito das medidas de peso determinadas nas zonas de pesca, verificou-se que na espécie denominada tucunaré borboleta (Cichla orinocensis), a variação foi de $0,7 \mathrm{~kg}$ a 2,2 $\mathrm{kg}$. Na zona 6 verificou-se os maiores pesos médios dos animais capturados com 2,2 kg, o segundo maior peso médio dos tucunarés borboleta foi na zona de pesca 1, com 1,4 kg; nas 
zonas de pesca 4 e 5 o peso médio dos peixes foi de $1,0 \mathrm{~kg}$; já nas zonas de pesca 2 e 3 os pesos médios dos animais capturados foram de $0,7 \mathrm{~kg}$.

O mesmo comportamento foi observado para os tucunarés borboletas, onde as unidades de conservação não influenciaram diretamente nos pesos dos peixes em relação à distância destas unidades de conservação existentes na área de estudo. O que leva a crer que a intensidade de pesca ainda não é suficiente para diminuir os estoques pesqueiros, não havendo a necessidade de uma recuperação desse estoque, ou seja, a quantidade de peixes ao longo de todo o trecho do rio é ótima para a prática de boas pescarias, tanto que ano após ano, aumenta a procura de pescadores esportivos querendo pescar no Rio Água Boa do Univini. (Figura 24).

Figura 24 - Medidas de peso de tucunaré borboleta capturados nas zonas de pesca.

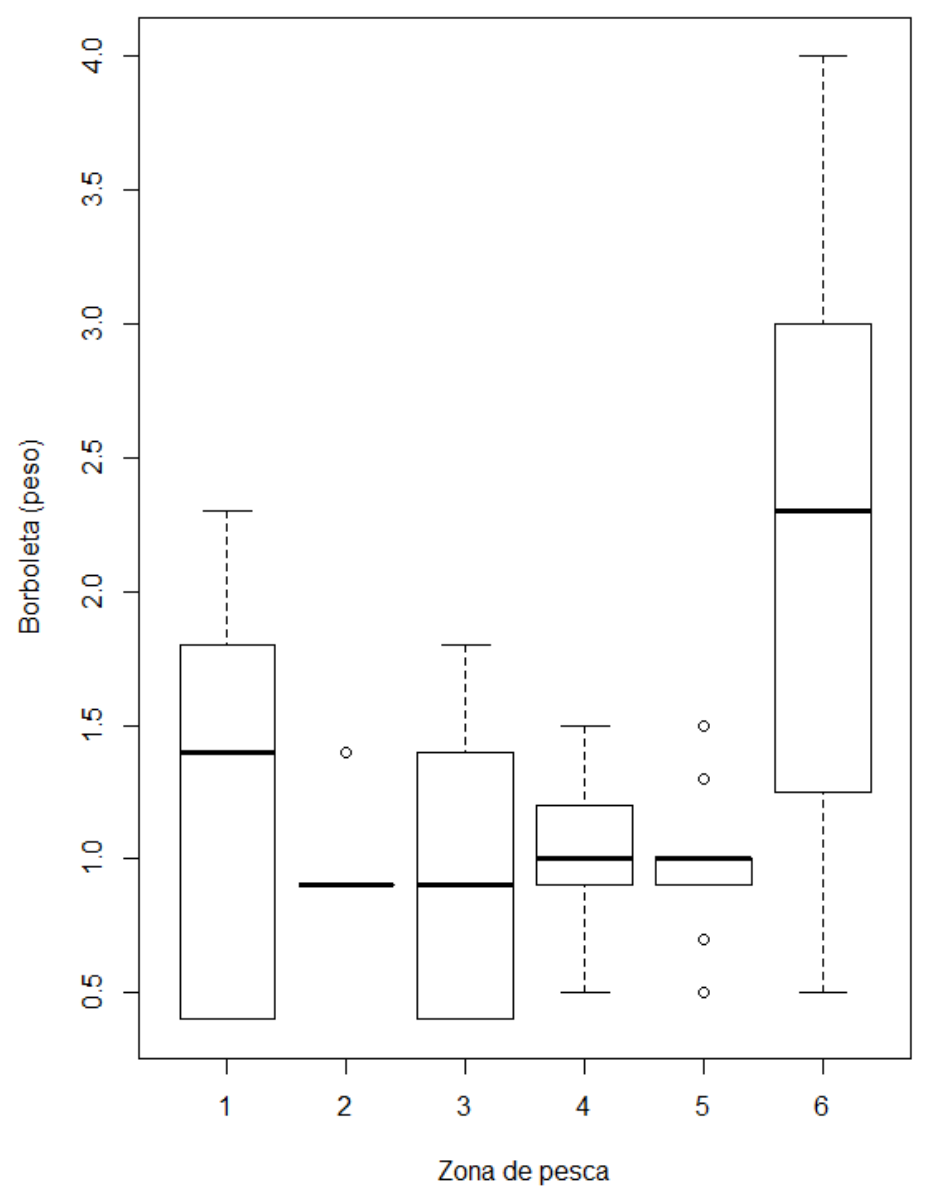

O número de peixes capturados pelos pescadores esportivos nas zonas 1, 2, 3, 4, 5 e 6 foram os seguintes. Para a captura do tucunaré açu (Cichla temensis), a zona de pesca 4 apresentou o maior número de peixes com 4 tucunarés açu. As zonas 1 e 6 apresentaram 3 
tucunarés açu, a zona de pesca 2 apresentou 2 tucunarés açu, enquanto nas zonas de pesca 3 e 5 foram capturados 1 peixe, respectivamente.

Estudando a figura 25, percebe-se que não existe uma relação direta da influência das unidades de conservação com o número de peixes capturados nas respectivas zonas de pesca. O que comprova que a pesca esportiva no local é de baixo impacto, não afetando os estoques pesqueiros, deixando o rio em questão bastante piscoso.

Figura 25 - Número de tucunarés açú capturados nas zonas de pesca.

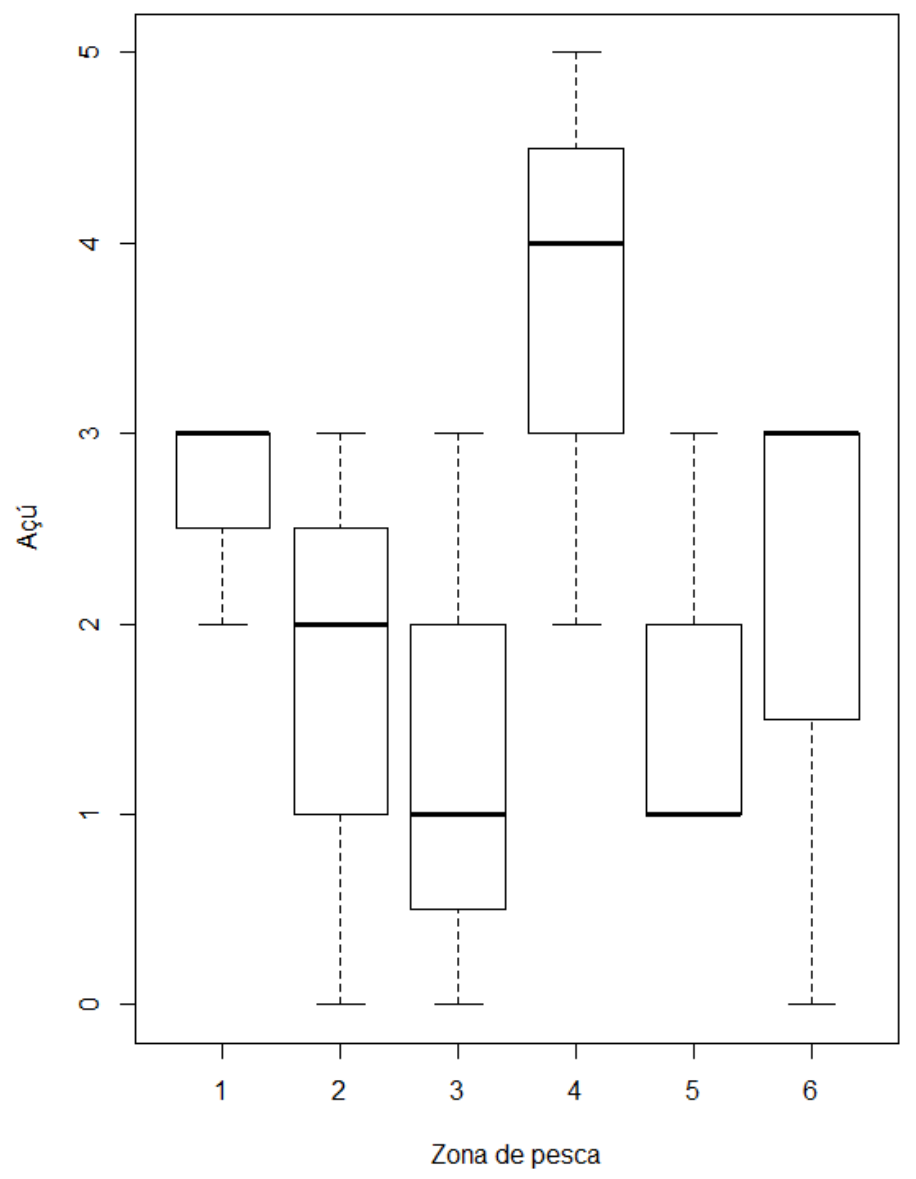

Com relação ao número de tucunarés paca (Cichla temensis) na zona de pesca 3 foram capturados pelos pescadores esportivos 25 peixes, sendo considerada a zona de pesca com maior quantidade de animais capturados. Nas zonas de pesca 2 e 6 foram capturados 8 peixes, respectivamente. Nas zonas 1 e 4 a captura dos animais foi de 5 peixes, enquanto a zona de pesca 5 apresentou o menor número de peixes com 3 peixes. 
Novamente observou-se que não houve relação direta da influência das unidades de conservação com os números de tucunarés paca capturados durante a pesca experimental, como mencionado, a intensidade de pesca não foi suficiente para afetar os estoques pesqueiros do Rio Água Boa do Univini, isto é, rio bastante piscoso (Figura 26).

Figura 26 - Número de tucunarés paca capturados nas zonas de pesca.

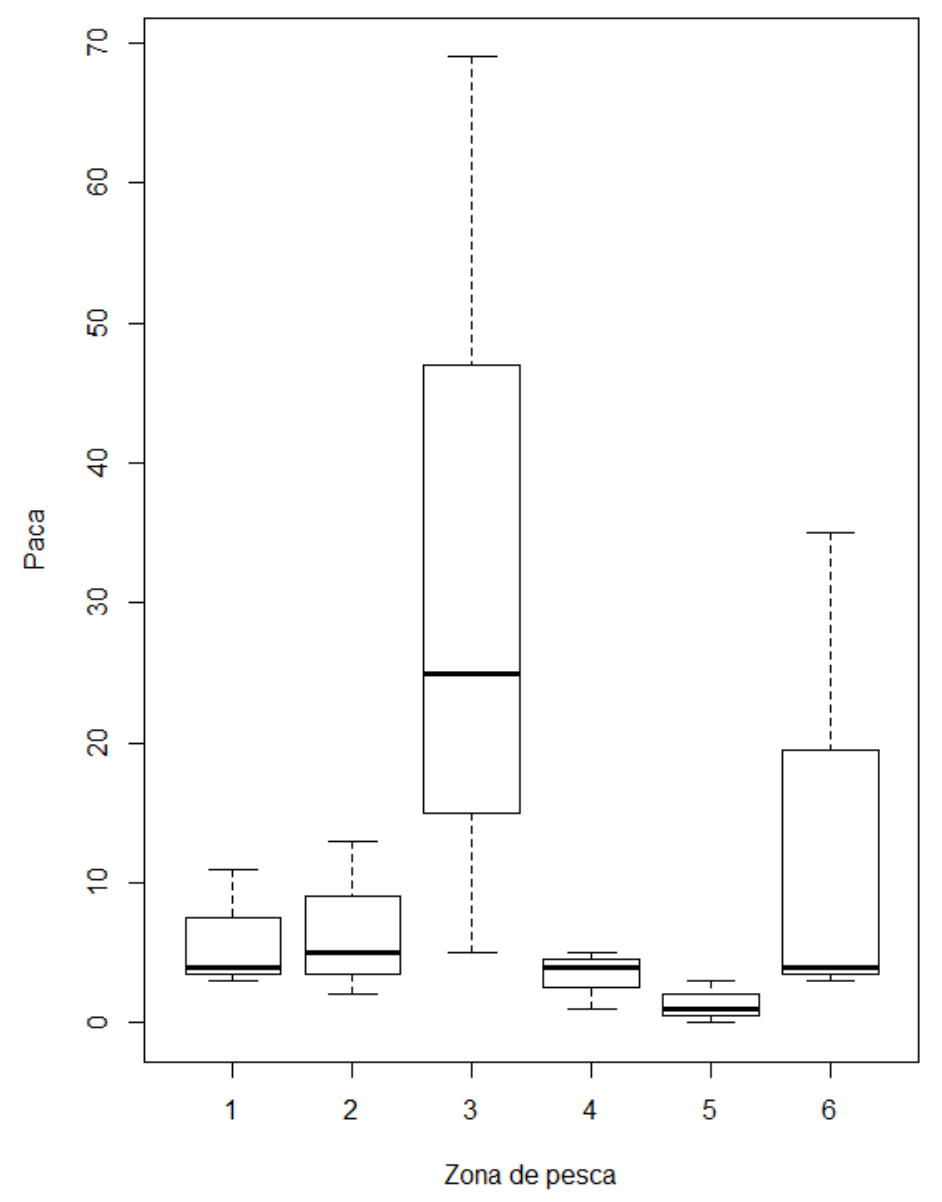

Para determinação do número de tucunarés tauá (Cichla monoculus) na zona de pesca 2 foram capturados 10 exemplares. Na zona 6 foram capturados 5 tucunarés tauá, entretanto, nas zonas de pesca 1, 3, 4 e 5 não houve captura de peixes.

Visualizando o boxplot verifica-se que não existe relação da influência direta das unidades de conservação existentes na área de estudo com o número de peixes capturados, verificou-se que a intensidade de pesca experimental realizado no presente estudo não foi suficiente para afetar os estoques pesqueiros, observando que o rio em questão apresenta, ao longo de seu trecho, grande quantidade de peixes, onde se pode praticar boas pescarias (Figura 27). 
Figura 27 - Número de tucunarés tauá capturados nas zonas de pesca.

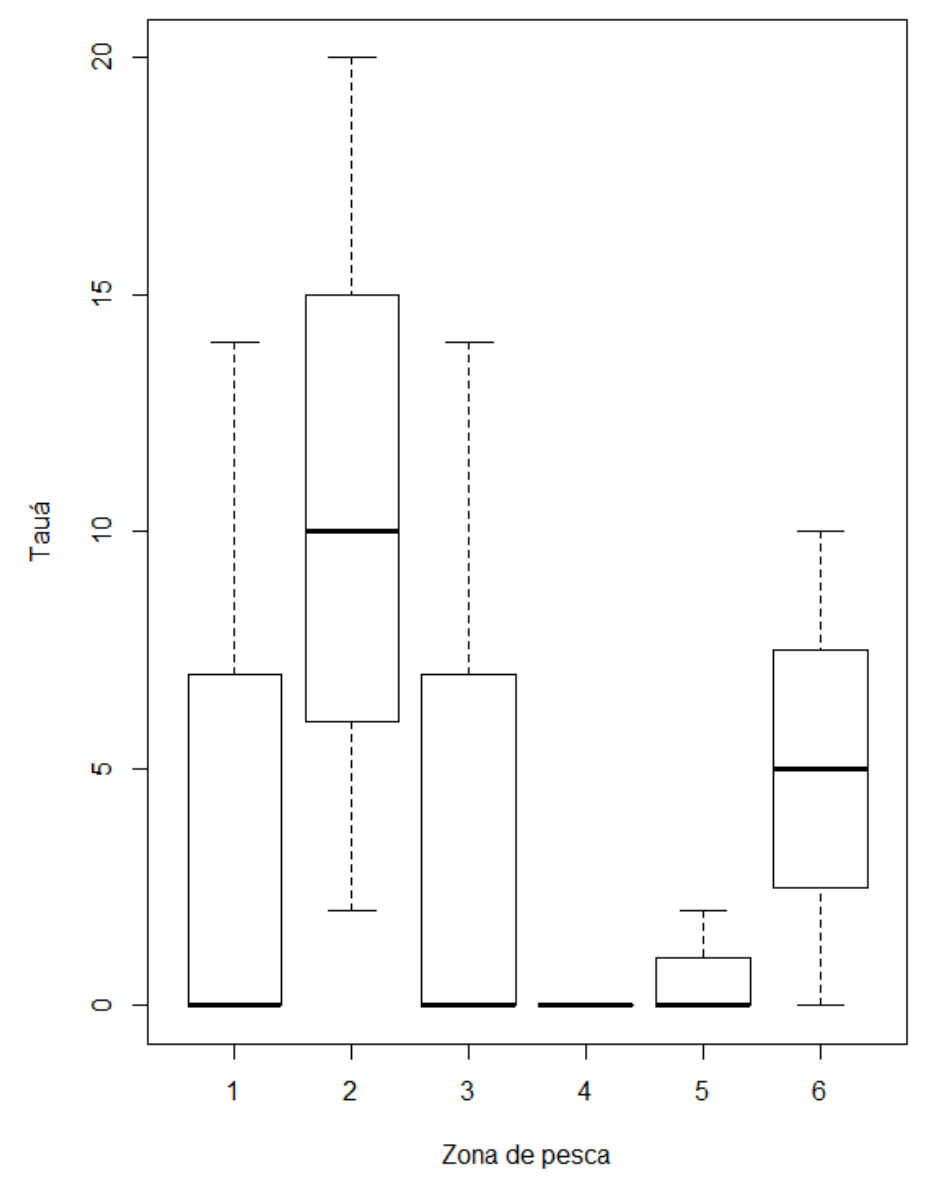

Visualizado o boxplot com relação à captura do tucunaré borboleta (Cichla orinocensis) nota-se que a zona de pesca 2 apresenta o maior número de tucunarés borboleta capturados, 78 animais fisgados pelos pescadores. As zonas de pesca 1 e 6 capturaram o mesmo quantitativo de peixes, isto é, 30 tucunarés borboletas, respectivamente. A zona 4 apresenta a terceira maior quantidade de peixes capturados com 18 espécies. Em seguida a zona 5 apresenta 15 peixes capturados. A zona de pesca 3 não capturou nenhuma espécie de borboleta.

Verificou-se que foi a espécie mais capturada em relação ao tucunaré açu, tucunaré paca e ao tucunaré tauá, devido ao seu tamanho, eles são mais ágeis e os primeiros a alcançarem as iscas (moscas) em relação aos demais, em razão disso, são mais os capturados.

Nota-se também que não há uma relação direta das unidades de conservação com a captura total dos tucunarés borboleta em relação à distância destas unidades de conservação existentes na área de estudo. Observou-se que o sistema de pesca esportiva praticado no 
sistema de pesque-e-solte não afetou os estoques pesqueiros no Rio Água Boa do Univini (Figura 28).

Figura 28 - Número de tucunaré borboleta capturados nas zonas de pesca.

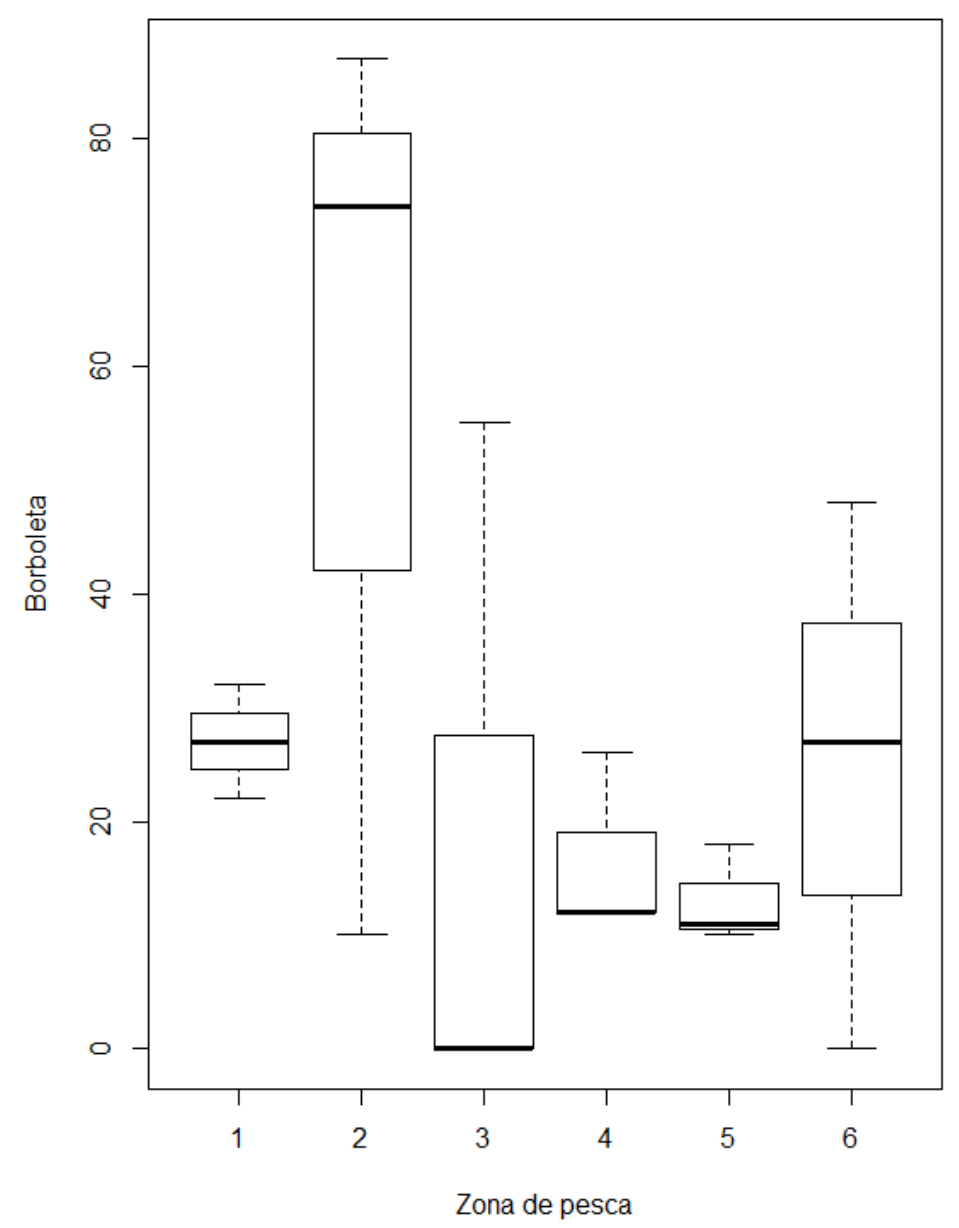

Percebe-se existir uma grande densidade de peixes esportivos no Rio Água Boa do Univini e, mesmo à medida que passa a temporada e aumenta a pressão de pesca pelos pescadores, os peixes não diminuíram sua ação nos ataques às iscas artificiais. $\mathrm{O}$ que caracteriza a excelente piscosidade desse rio, atraindo os pescadores aficionados pela pesca esportiva do tucunaré, considerado o embaixador da pesca esportiva na Amazônia.

\subsection{PERFIL DO PESCADOR ESPORTIVO}

\subsubsection{Pescador esportivo estrangeiro}

Devido ao alto grau de informalidade existente no segmento, existem poucos dados e informações sobre essa atividade, principalmente sobre o perfil do turista, quantidade de 
turistas nos locais de pesca, períodos de maior e menor visitação, tempo despendido com a atividade. Nesse sentido, buscou-se conhecer a realidade dos turistas frequentadores da pesca esportiva no baixo Rio Branco, em especial, os usuários do Rio Água Boa do Univini, em Roraima, Brasil, o que não é uma tarefa muito fácil.

Diante dessa situação, buscou-se conhecer melhor os pescadores frequentadores do hotel de selva, situado no Rio Água Boa do Univini, durante a temporada de pesca 20182019. Foram entrevistados 20 pescadores esportivos estrangeiros. Quanto à faixa etária dos respondentes, observou-se que $40 \%$ está com idade entre 71 a 80 anos, portanto, turistas com certa experiência e que já pescaram no hotel de selva várias vezes; $35 \%$ dos entrevistados apresentam idade entre 61 a 70 anos e também já estiveram outras vezes pescando no lodge; $10 \%$ é a composição de idade de dois grupos de pescadores, um grupo com faixa etária de 30 a 40 anos e outro com 81 a 90 anos, e finalmente, 5\% dos respondentes têm idade entre 41 a 50 anos. Vale ressaltar que a grande maioria dos pescadores esportivos vem ao Rio Água Boa do Univini pescar quase todo o ano, são considerados um público praticamente cativo deste pedaço do Brasil.

Figura 29 - Faixa etária dos pescadores.

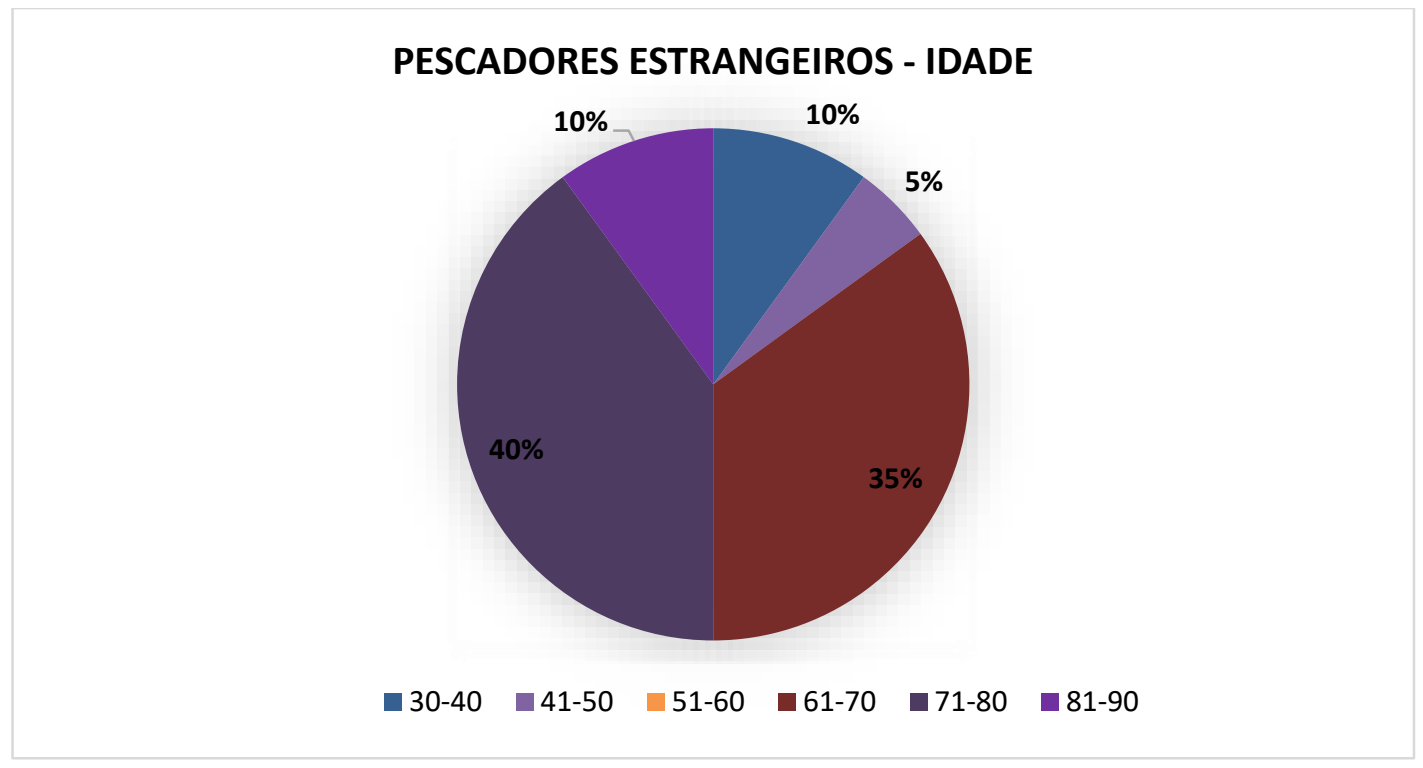

Fonte: O autor, 2019.

Dos respondentes, $80 \%$ são do sexo masculino e $20 \%$ do sexo feminino. Verificou-se na fala dos pescadores que há um crescimento das mulheres na prática da pesca esportiva no mundo. Essa informação é corroborada pela Associação Nacional de Ecologia e Pesca 
Esportiva (ANEPE, 2018), hoje em dia é muito comum ver as mulheres acompanhando seus maridos ou indo com as amigas praticar a pescaria.

Figura 30 - Relação de gênero dos pescadores.

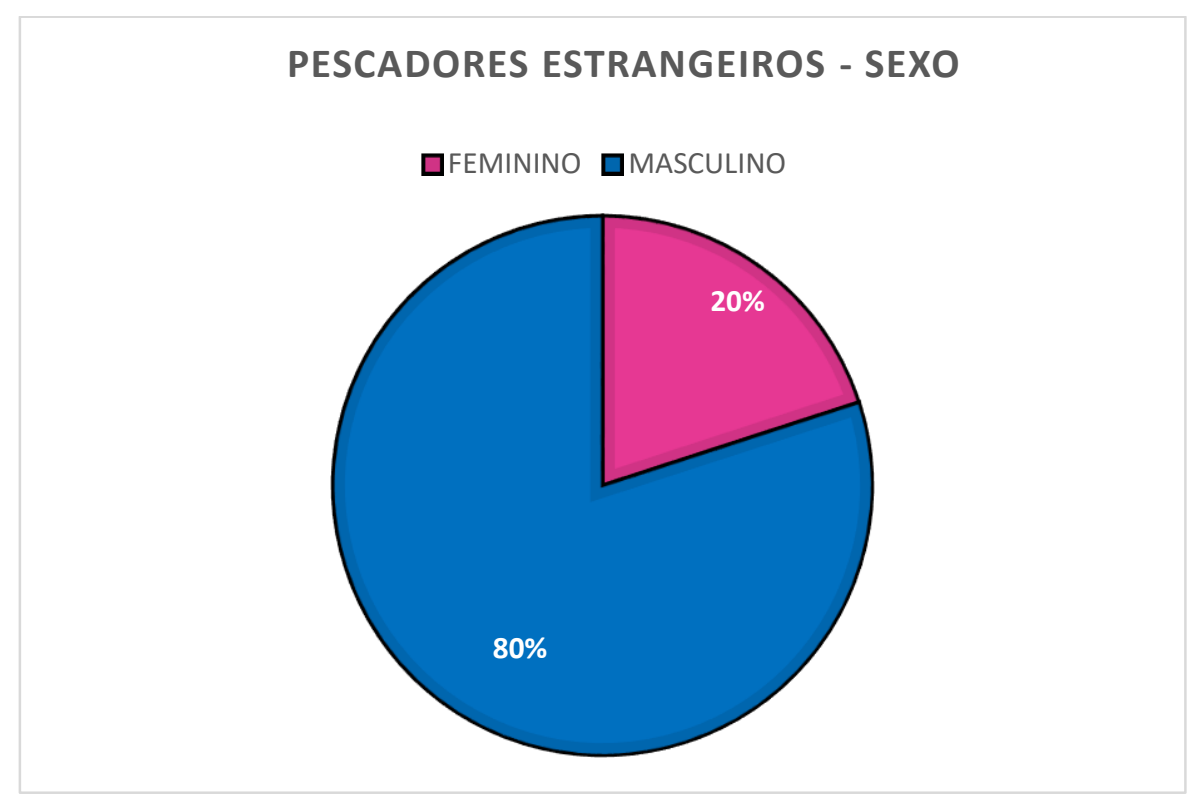

Fonte: O autor, 2019.

Quanto ao estado civil, 95\% dos entrevistados são casados, e 5\% são separados.

Figura 31 - Estado civil dos pescadores.

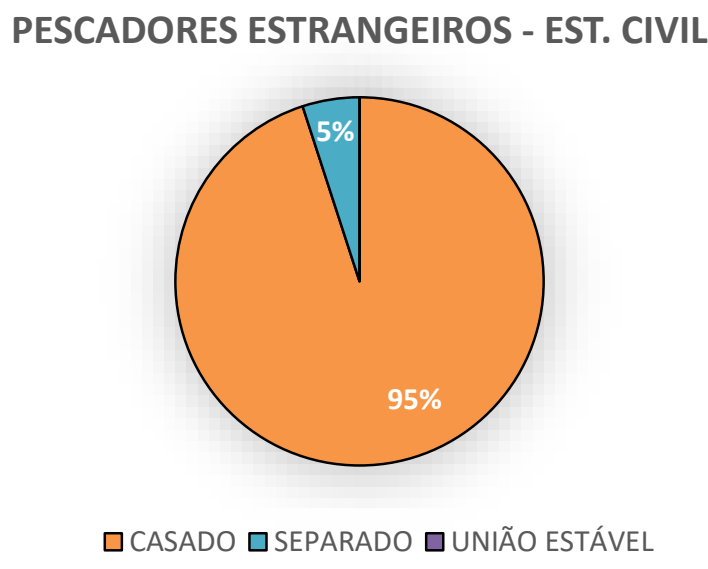

Fonte: O autor, 2019.

Quanto ao nível de escolaridade, mostrado por meio da figura 18, a maioria (65\%) possui o Ensino Superior Completo; $15 \%$ tem o curso superior com Pós-graduação a nível de 
Mestrado e $10 \%$ com nível de Doutorado e 10\% dos entrevistados possui Ensino Médio Completo.

Figura 32 - Escolaridade dos pescadores.

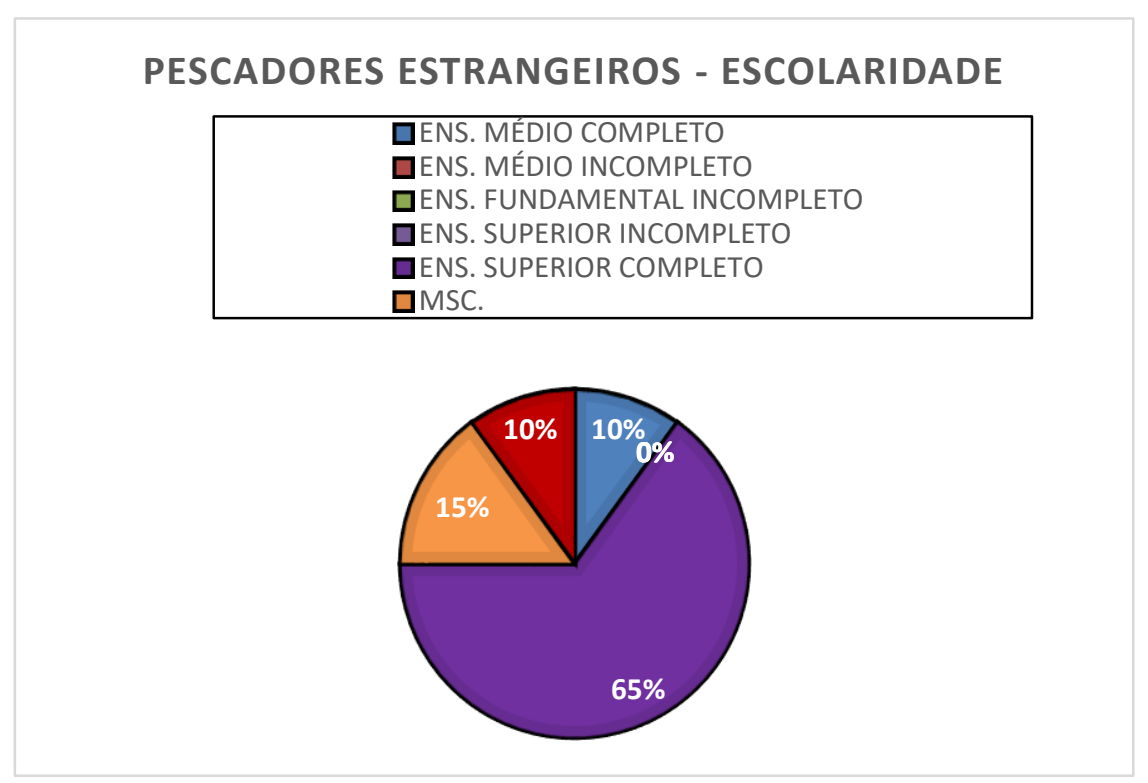

Fonte: $\mathrm{O}$ autor, 2019.

Com respeito à renda dos entrevistados, $100 \%$ apresentam renda superior a 10 salários mínimos.

Destes entrevistados, $57 \%$ praticam essa atividade mais de 20 anos, pescando em rios, lagos e ressacas em quase todo o mundo; $33 \%$ já pescam em vários rios também no mundo e exercem essa atividade há 10 e 20 anos; $10 \%$ praticam a pesca entre 1 a 10 anos.

Figura 33 - Tempo que pratica a pesca amadora/esportiva.

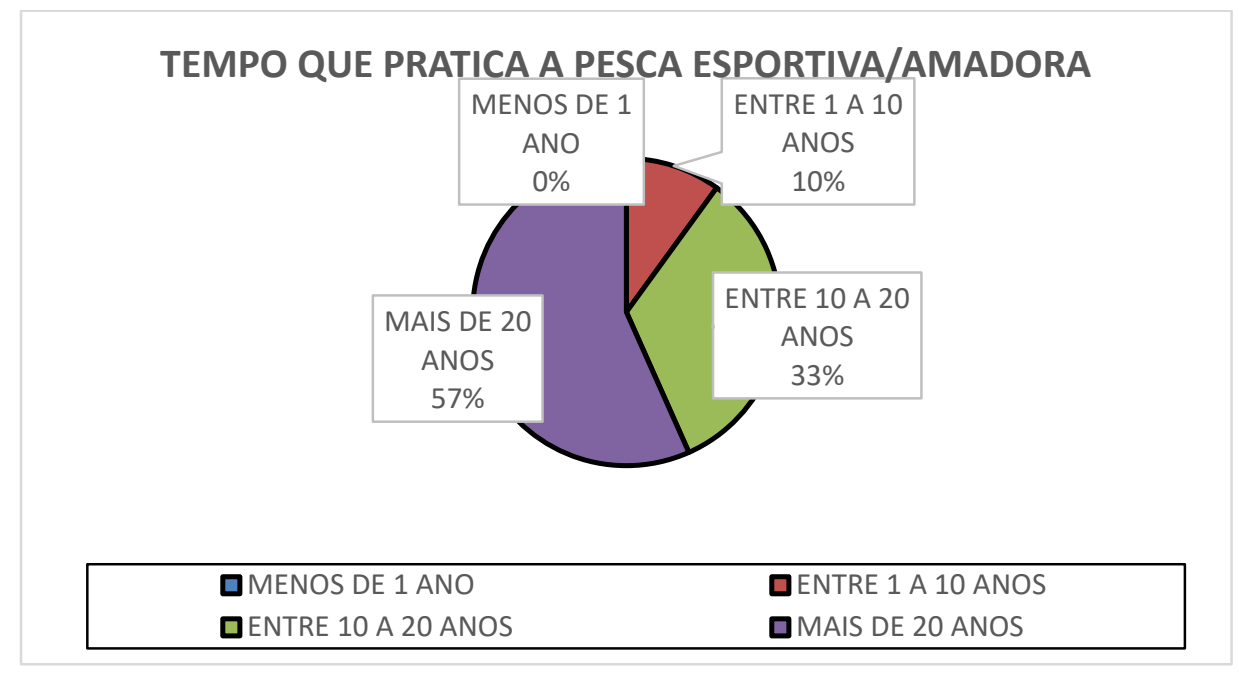

Fonte: O autor, 2019. 
Com relação à frequência de pescaria respondida pelos entrevistados11\% pescam semanalmente; $42 \%$, semestralmente, enquanto $47 \%$, mensalmente, pescam como forma de lazer em seu país e em outras partes do mundo. Segundo resposta dos entrevistados, a pesca é uma das suas preferências, é considerado o seu melhor hobby.

Figura 34 - Frequência de pescaria.

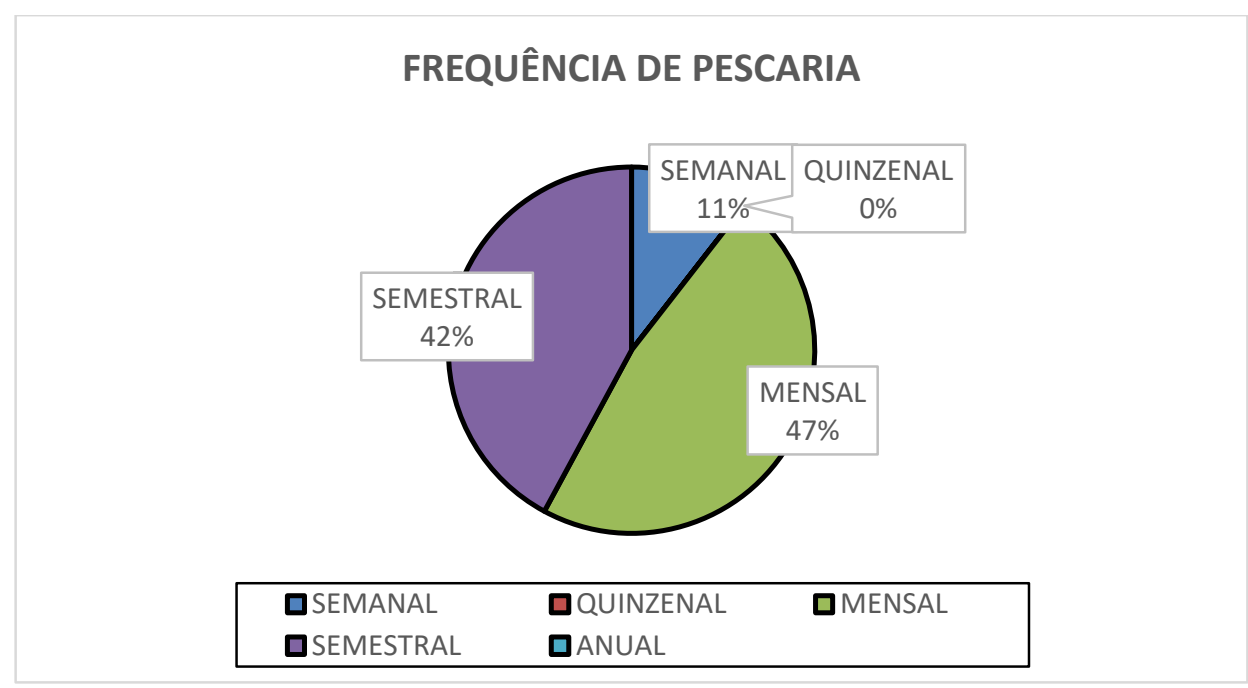

Fonte: O autor, 2019.

A respeito da profissão e trabalho dos pescadores esportivos que responderam às perguntas do questionário aplicado, eles trabalham em diversas atividades: 7 atuam como empresários em suas cidades; 2 como consultores financeiros; 2 atuam na área de Medicina, são médicos em suas cidades, as demais áreas de trabalho identificadas nos apontamentos são: Engenheiro Elétrico, Diretor de Vendas, Dentista, Engenheiro Florestal, Fazendeiro, Técnico em Computação, Fotógrafo Profissional, Juiz Federal e Ator de Cinema. 
Figura 35 - Profissão dos pescadores

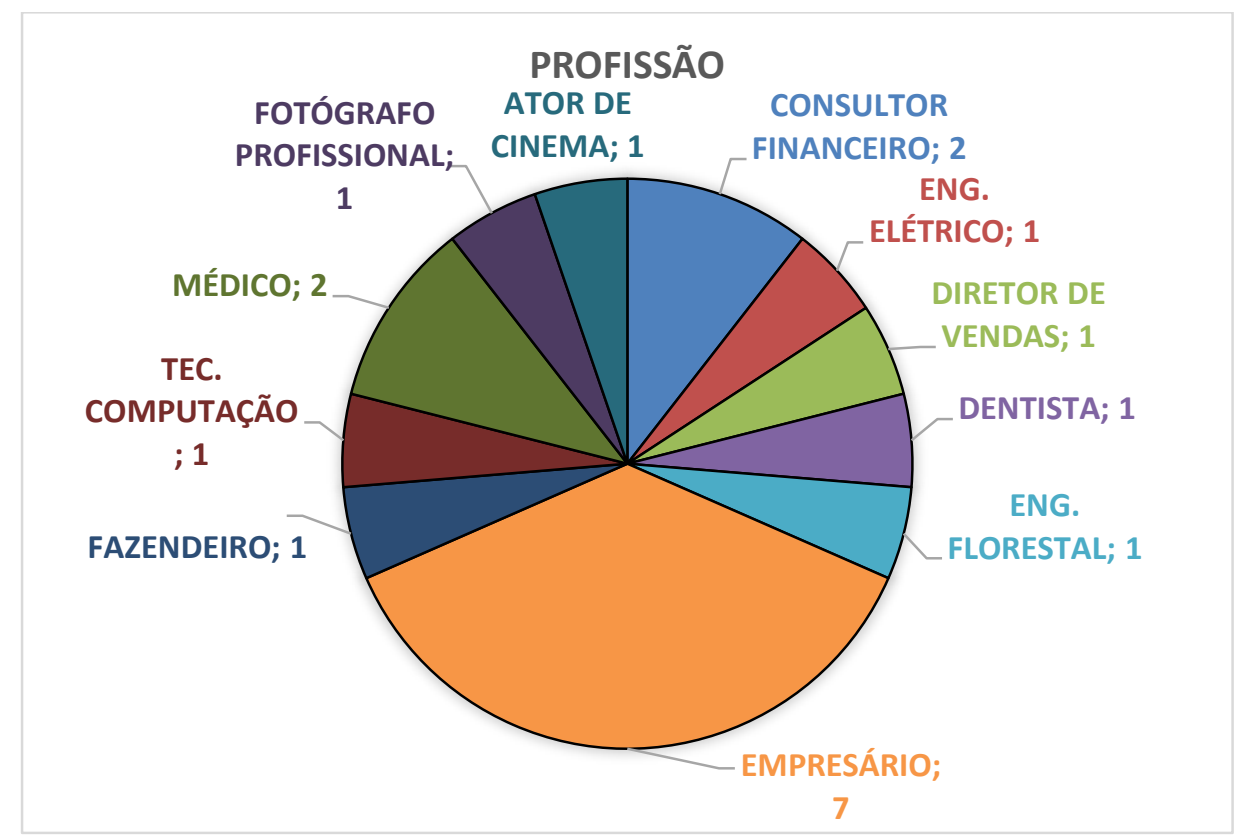

Fonte: O autor, 2019.

Houve uma predominância da procedência dos pescadores esportivos oriundos dos Estados Unidos da América, 95\% das participações nas entrevistas. 3\% pescadores esportivos vindos da Nova Zelândia e $2 \%$ de participação de pescadores esportivos vindos da Austrália. O Água Boa Amazon Lodge tem agentes de turismo nos Estados Unidos da América, África do Sul, Austrália, Suíça, Canadá e Inglaterra. Com relação aos Estados Unidos da América o hotel de selva tem agentes captadores de clientes nos seguintes estados: Montana, Washington, Califórnia, Idaho, Wyoming, Carolina do Norte, Alabama, Colorado entre outros estados, o que confere aos Estados Unidos da América uma participação grande dos pescadores esportivos no Rio Água Boa do Univini, onde o hotel de selva fica localizado. 
Figura 36 - Nacionalidade dos pescadores.

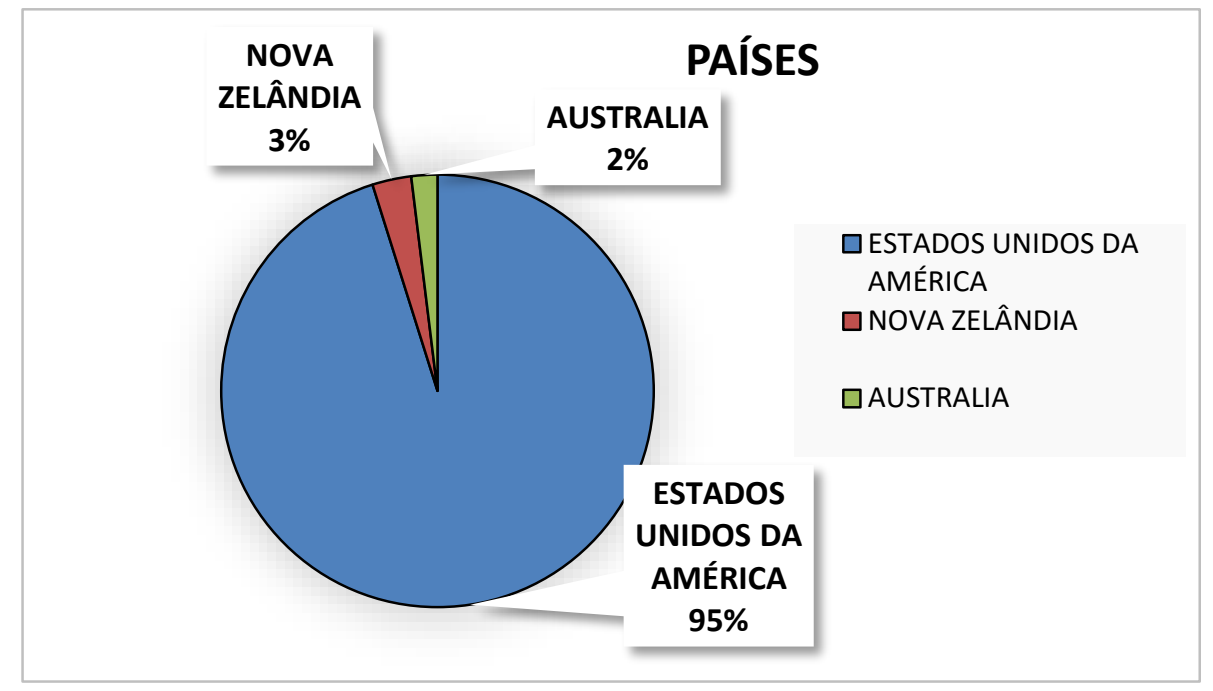

Fonte: O autor, 2019.

Os pescadores esportivos passam o período de uma semana de pesca no hotel de selva, pescam sete dias, em torno de oito horas por dia.

Cerca de $65 \%$ dos entrevistados gastam com pescaria mais de UU\$ 600/dia, enquanto $35 \%$ gastam entre U\$121 a U\$ 145/dia com pescaria. Com respeito aos valores gastos com equipamentos de pesca, 98\% investem mais de U\$2.415/dia, já 2\% gastam entre U\$ 1.207 a U\$ 2.415 por dia, para terem os melhores equipamentos de pesca amadora/esportiva. Esses valores são gastos com compras de varas de pesca, bobinas, linhas multifilamentos, fly line, iscas artificiais de superfície, subsuperfície e meia-água. Todos os pescadores esportivos estrangeiros pescam na modalidade de flyfishing.

\subsubsection{Pescador esportivo nacional}

Seguindo a mesma metodologia empregado na coleta de informações aplicada para os pescadores esportivos estrangeiros, foram entrevistados 20 pescadores esportivos nacionais. Quanto à faixa etária 18\% dos entrevistados têm de 30 a 40 anos; 44\%, de 41 a 50 anos; 27\% têm entre 51 a 60 anos e $11 \%$ têm entre 61 a 70 anos. Observa-se que praticamente a metade dos respondentes situa-se na faixa etária de 41 a 50 anos, considerados jovens pescadores. 
Figura 37 - Faixa etária dos entrevistados.

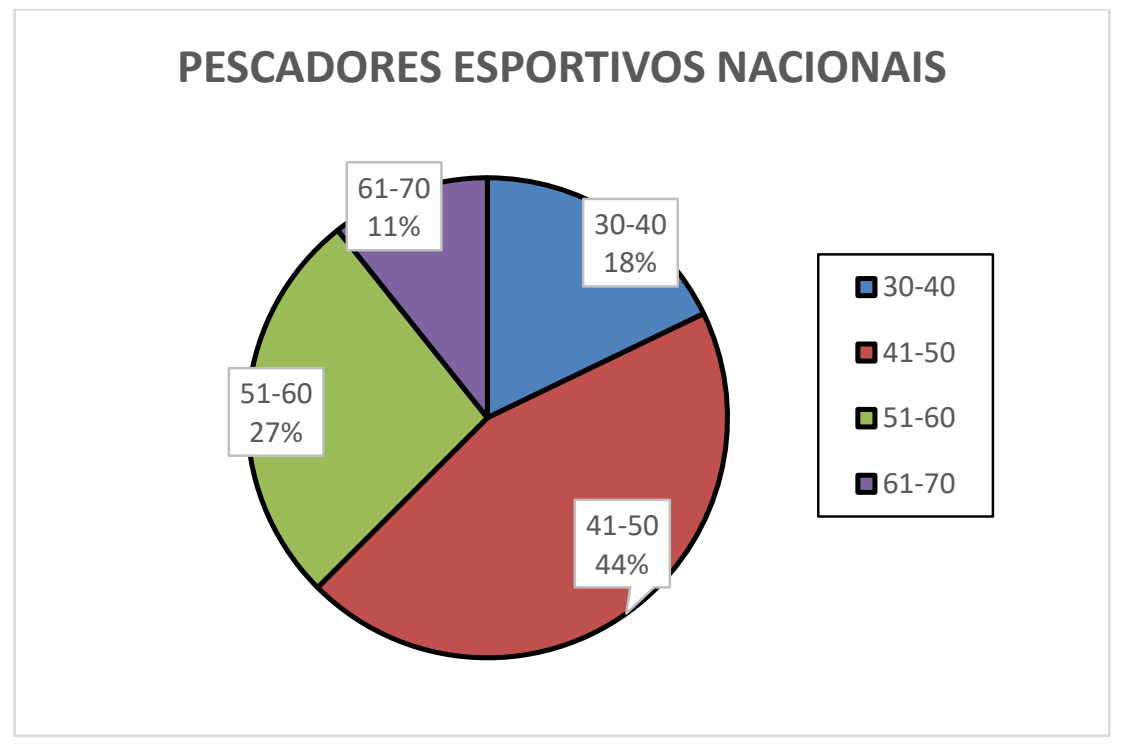

Fonte: O autor, 2019.

Com relação ao gênero, $85 \%$ são do sexo masculino e $15 \%$ do sexo feminino. Assim como nas respostas dos perguntas dos questionários aplicados aos pescadores esportivos estrangeiros, há uma tendência de crescimento da participação da mulher brasileira na pesca esportiva, segundo a ANEPE (2018).

Figura 38 - Gêneros dos entrevistados.

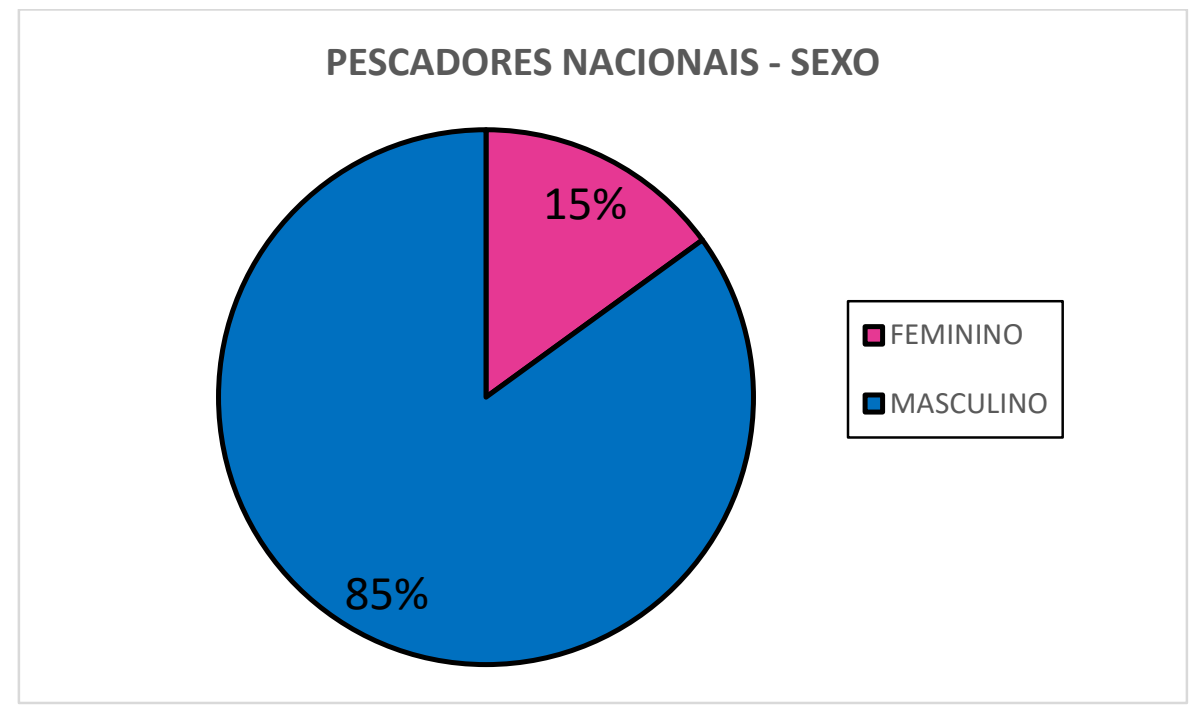

Fonte: O autor, 2019.

Quanto ao estado civil, $75 \%$ dos entrevistados são casados e $25 \%$ vivem em união consensual, conforme a figura a seguir. 
Figura 39 - Estado civil dos entrevistados.

\section{PESCADORES NACIONAIS - ESTADO CIVIL}

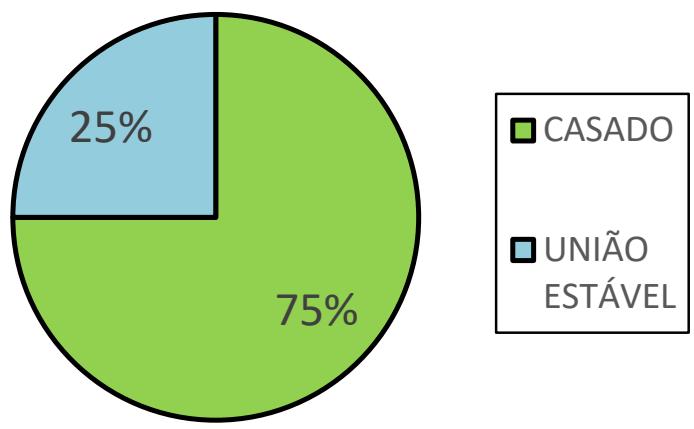

Fonte: O autor, 2019.

A respeito do grau de escolaridade mostrado por meio da figura $26,5 \%$ não concluíram o ensino fundamental, $10 \%$ possui o ensino médio completo, enquanto $5 \%$ não concluíram o ensino médio. Com relação ao ensino superior $75 \%$ tem formação superior enquanto $5 \%$ não concluíram seus estudos.

Figura 40 - Escolaridade dos entrevistados.

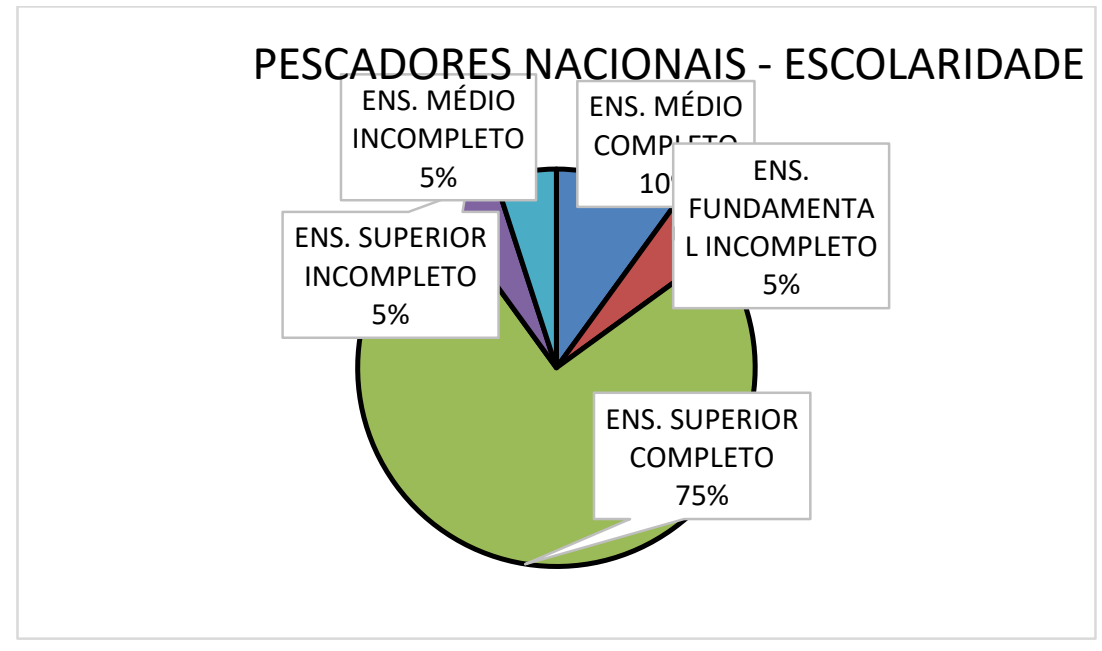

Fonte: O autor, 2019.

Os pescadores nacionais apresentam Renda Mensal bastante diversa: 20\% tem rendimentos entre 1 a 5 salários mínimos; na faixa de 6 a 10 salários mínimos o percentual é de $20 \%$, enquanto $60 \%$ recebem mais que 10 salários mínimos. 
Figura 41 - Renda familiar dos entrevistados.

Fonte: O autor, 2019.

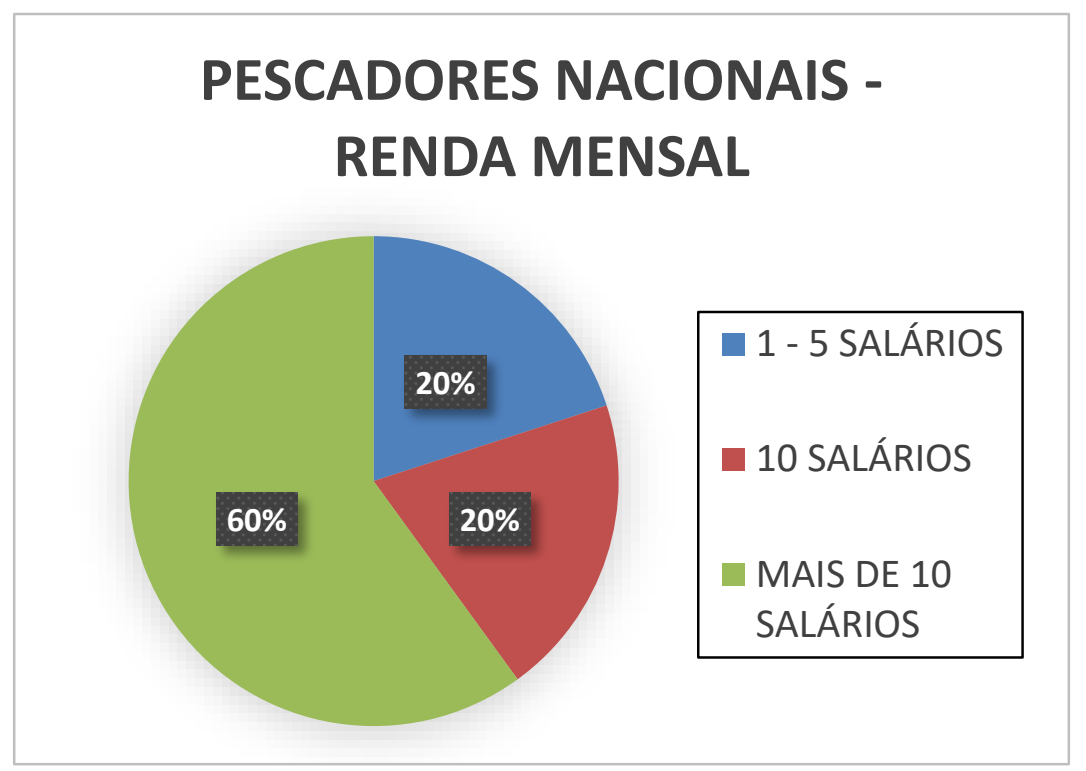

Fonte: O autor, 2019.

Ainda analisando o perfil do pescador esportivo que praticou a pesca nessa temporada, verificamos que, com relação à prática de pesca esportiva 30\%, ou seja, 6 pescadores entrevistados praticam a pesca entre 1 a 10 anos; 7 pescadores, ou 35\% pescam entre 10 a 20 anos, e 35\% ou 7 pescadores esportivos já praticam essa modalidade de pesca há mais de 20 anos.

Figura 42 - Tempo que pratica a pesca esportiva.

\section{PESCADORES NACIONAIS - TEMPO DE PRÁTICA}

$\square$ MENOS DE 1 ANO $\square 1$ A 10 ANOS $\square 10$ A 20 ANOS $\square$ MAIS DE 20 ANOS

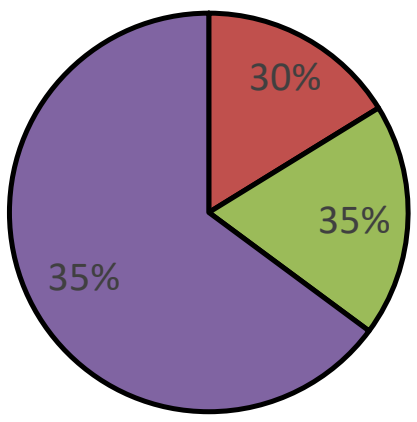

Fonte: O autor, 2019. 
Com relação à frequência de pescaria, esses entrevistados apontaram que $6 \%$ pescam quinzenalmente; $28 \%$ aproveitam seu tempo pescando mensalmente; $44 \%$ recuperam seu estado de estresse pescando semestralmente, enquanto $22 \%$ pescam anualmente, com objetivos de relaxamento mental.

Figura 43 - Frequência de pescaria.

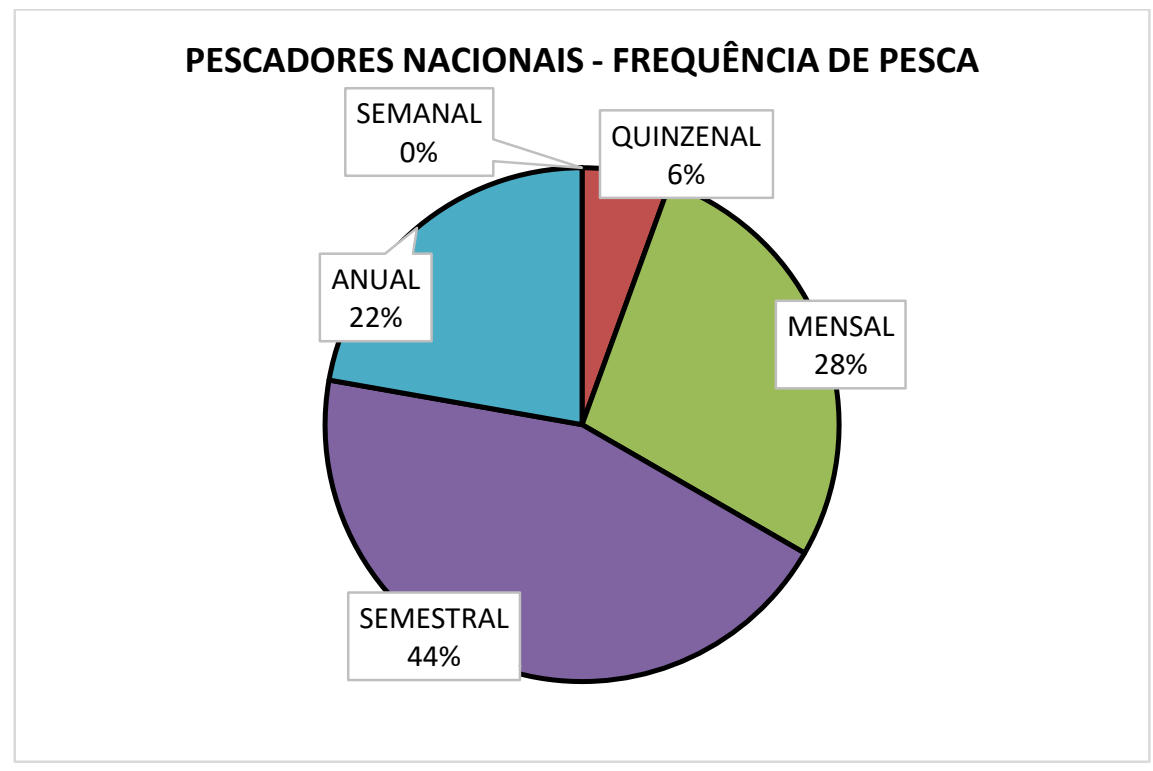

Fonte: O autor, 2019.

A procedência desses pescadores esportivos nacionais é dos seguintes estados da Federação brasileira: 7 pescadores de Jundiaí e 3 de Santo André, ambos do Estado de São Paulo; 3 pescadores do Estado do Rio de Janeiro; 2 pescadores de Belo Horizonte e 2 pescadores de Araxá, ambas as cidades em Minas Gerias; participando com apenas 1 pescador esportivo estão as cidades de Imperatriz - MA, Goiânia - GO e Teixeira de Freitas-BA.

Com relação à ocupação e trabalho, houve uma variação das atividades desenvolvidas no dia-a-dia dos respondentes, 20\% afirmaram que trabalham como Engenheiro Geólogo; $15 \%$ declararam- se administradores de empresas e também $15 \%$ atuam como empresários em seus municípios; $10 \%$ realizam suas atividades como funcionários públicos federias; 5\% trabalham como: motorista, metalúrgico, auxiliar II de logística, torneiro mecânico, representante comercial, nutricionista e engenheiros de alimentos e florestal.

Com relação às características das pescarias, os pescadores esportivos compraram o pacote da empresa de pesca esportiva, pescam em torno de seis a sete horas por dia, durante 5 dias, capturando tucunarés com comprimento e peso variados. Os peixes capturados na 
temporada variavam de $0,45 \mathrm{~kg}$ até $9 \mathrm{~kg}$ e, em termos de tamanho, foram capturados peixes de 30 a 88 centímetros.

Quando o tucunaré é fisgado com as iscas artificiais de superfície, o impacto visual da explosão dramática na água ou o peixe saltando com a isca na boca é uma sensação sentida pelo pescador esportivo, tornando-se uma experiência inesquecível na sua pesca em que a adrenalina 'vai a mil' quando a explosão acontece nas mãos desse pescador que utiliza um excelente equipamento de pesca. Em razão disto, dos 20 respondentes dos questionários aplicados nos grupos de turistas, todos relataram que a cada ano que passa ficam mais apaixonados pela pesca esportiva, tornando-se exímios pescadores, fazendo lançamentos precisos no meio do labirinto de galhos e troncos de árvores no Rio Água Boa do Univini sem prender a isca e ainda escolhe sua isca em equilíbrio com os demais materiais, em função das condições da água, da época do ano, do tempo e tipo de peixe que desejam capturar. Isso faz com que $85 \%$ dos pescadores façam investimentos financeiros em mais de $\mathrm{R} \$ 600,00$ por dia nessa atividade, na aquisição de tralhas para a captura do tucunaré, incluindo varas, linhas, grampos, molinetes, carretilhas e iscas artificiais. Enquanto 5\% gastam entre R\$ 100 a R\$ 600,00 por dia em pescaria.

O sistema de pesca praticado pelos pescadores usuários do hotel flutuante é a pesca de arremesso (Baicasting) com uso de molinete e carretilha. 


\section{DISCUSSÃO}

No experimento realizado durante a temporada de pesca esportiva de 2018/2019, para a determinação da capacidade de carga de pesca esportiva no Rio Água Boa do Univini, na região do baixo Rio Branco, em Roraima, Brasil, empregou-se a metodologia de Miguel Cifuentes (1992) adaptada para as condições desse rio, típico de sistemas de águas pretas da Amazônia. De acordo com Siles (2003), essa adaptação foi realizada em função de que essa metodologia foi desenvolvida para ambientes terrestres, sendo muito útil para manejar recursos naturais renováveis, especialmente florestas e pastagens.

Ainda segundo Siles (2003), esse modelo oferece um procedimento fácil, rápido e útil para a determinação das capacidades de cargas física, real e efetiva do atrativo natural em questão. O método considera alguns dos problemas que os empreendimentos costumam apresentar como falta de pessoal capacitado, a dificuldade de manejo, a insuficiência de informação e a dificuldade de acesso.

No presente trabalho, a Capacidade de Carga de Pesca Esportiva foi utilizada como um ponto de referência, isto é, como um ponto de partida para a administração dos impactos da visitação, a qual deverá ser complementada com instruções aos pescadores esportivos embarcados antes de iniciar a pescaria e atenção e monitoramento do uso dos lagos, ressacas e igarapés adjacentes.

$\mathrm{Na}$ área pesquisada, considerando como período de pesca 9 horas por dia, conclui-se que existe possibilidade de trabalho para os dois empreendimentos que operam simultaneamente no Rio Água Boa do Univini. Onde cada empreendimento opera com seis embarcações, atendendo no máximo 12 pescadores atuando na pesca do tucunaré. O fluxo total de barcos utilizados pelo Água Boa Amazon Lodege e Porto Tur - Pesca Esportiva é de 12 barcos motorizados. Estes barcos seriam distribuídos de forma a revezar áreas de atuação. Esta proposta considera pesca apenas nos lagos e ressacas da margem direita do rio, região de entorno da reserva, supondo que os lagos da margem esquerda estejam dentro da área protegida, com acesso restrito (ANDRETTA et al, 2005).

Analisamos a influência direta das unidades de conservação: Parque Nacional Serra da Mocidade e Estação Ecológica Niquiá dentro da sub-bacia do Rio Água Boa do Univini, como fonte de reposição para os estoques pesqueiros de tucunaré (Cichla spp.), considerando 
comprimento, peso e número total das quatro espécies de tucunaré: açu, paca, tauá e borboleta, como variáveis repostas. Em face da ocorrência de resíduos heterocedásticos, o teste não-paramétrico de Kruskal-Wallys foi empregado, usando o teste de Wilcoxon como teste pareado para comparação a posterior, uma vez que a hipótese H0 foi rejeitada.

Observou-se através das ilustrações dos boxplot das quatro espécies de tucunaré estudadas que as duas unidades de conservação existentes na área não exerceram influência direta sobre os peixes capturados ao longo do rio, independente desta captura ser realizada na zona 1, que é a foz do Rio Água Boa do Univini com o Rio Branco, zona mais distante das unidades de conservação, bem como a zona 6 , limite entre as duas unidade de conservação, que teoricamente poderia fornecer mais exemplares de tucunaré para o rio em questão, por estar mais protegida pela legislação da unidade de conservação de proteção integral.

Esse resultado deve ser analisado considerando diversos fatores. Em primeiro lugar, é possível que as unidades de conservação estejam atuando de forma benéfica, como área de repovoamento de tucunarés para toda a extensão do Rio Água Boa do Univini, propiciando a manutenção da captura de exemplares grandes em todas as áreas de pesca.

Para entender melhor quem são os turistas que frequentam essa região do baixo Rio Branco, buscou-se conhecer o pescador esportivo usuário do Rio Água Boa do Univini. Foram selecionadas técnicas de pesquisa em turismo, por meio de questionários referentes ao levantamento do perfil do pescador esportivo estrangeiro e nacional e guias de pesca (LAKATOS 2003). Os guias de pesca apresentam larga experiência na atividade, o tempo em que atuam nesse ramo varia de 10 a 22 anos, a grande maioria dos entrevistados trabalha quase que exclusivamente na pesca esportiva, durante os seis meses de temporada de pesca.

Com relação ao pescador esportivo estrangeiro 100 \% são praticantes de Flyfishing,. que é a pesca com mosca, considerada uma das mais antigas modalidades de pesca. Segundo Oliveira (2017), as moscas são as iscas artificiais mais antigas citadas em escritos do período da Dinastia Shang (2.000 a.C.), onde comenta-se o uso de moscas artificiais para pescar, considera-se que a modalidade começou na Macedônia. As moscas são iscas artificiais confeccionadas artesanalmente com pelos, penas, fios de plástico e linhas de costura, essa isca simula um inseto ou o alimento natural de alguns peixes. As iscas podem ser fabricadas artesanalmente pela maioria dos pescadores esportivos aficionados por essa modalidade de pesca. 
A pesca com mosca ou Flyfishing é realizada utilizando uma vara comprida flexível, uma carretilha semelhante a uma bobina comum, que servem como armazém da linha e não exercem nenhuma função de arremesso. Elas são únicas no sentido de que não possuem peso, e seu lançamento depende de linhas grossas, varas especiais para que sejam projetadas ao respectivo alvo, além de anzol simples e sem farpas, conhecidos por "mosca".

A faixa etária varia de 35 a 85 anos, sendo $80 \%$ do sexo masculino e $20 \%$ do sexo feminino; o estado civil: $95 \%$ casados e $5 \%$ separados; $65 \%$ tem ensino superior a nível de mestrado e de doutorado; $100 \%$ ganham mais de 10 salários mínimos. 57 \% dos entrevistados praticam a pesca esportiva há mais de 20 anos e $33 \%$ entre 10 a 20 anos; $47 \%$ dos respondentes tem uma frequência de pesca mensal, apresentam profissões diversas e são de origem de diversos países, investem mais de U\$ 600/dia em pescarias, comprando vestuários próprios para a pesca e equipamentos cada vez mais modernos de pesca esportiva.

Na pescaria de tucunarés no Rio Água Boa do Univini, praticada por pescadores esportivos nacionais, a pesca é realizada no sistema Baitcast (arremesso) com emprego de molinete e carretilha. Estes equipamentos são de extrema importância e com eles são possíveis arremessos mais certos e bem direcionados. Os modelos são variados, podendo existir muitos tipos de materiais, perfil, freio, recolhimento, arremesso, fricção, etc. As varas de pescar possuem diversos tamanhos e espessuras, são feitas de vários materiais: fibra, carbono, grafite ou outros materiais, possui tipos de ações, como lentas, rápidas, ultra-rápidas, médias e casting.

A influência destes materiais, do peso, espessura e tamanhos influenciam nos arremessos e em quais tipos de peixes o pescador gostaria de fisgar. A qualidade da linha de pesca é uma das principais preocupações para uma boa pescaria. Além da qualidade, outro ponto deve ser o seu objetivo. Se a busca é peixes mais pesados ou maiores, linhas mais espessas são essenciais. As linhas de monofilamentos e multifilamentos são as mais utilizadas nas pescarias.

As iscas mais utilizadas na modalidade de arremesso são as hélices, as poppers, as zaras, os jigs e as iscas de meia-água entre 10 e 16 centímetros, além de iscas denominadas de twitch baits, que trabalham pouca coisa abaixo da superfície, todavia, não possuem barbelas como as iscas de meia-água. $\mathrm{O}$ anzol certo é fundamental para o sucesso de uma boa pescaria.

Em razão disto, dos 20 respondentes dos questionários aplicados nos grupos de turistas brasileiros, todos, relataram que a cada ano que passa ficam mais apaixonados pela pesca 
esportiva, tornando-se exímios pescadores, fazendo lançamentos precisos no meio do labirinto de galhos e troncos de árvores no Rio Água Boa do Univini sem prender a isca e ainda escolhe sua isca em equilíbrio com o demais materiais, em função das condições da água, da época do ano, do tempo e tipo de peixe que desejar capturar.

Isso faz com que $85 \%$ dos pescadores façam investimentos financeiros de mais de $\mathrm{R} \$$ 600,00 por dia nessa atividade, na aquisição de tralhas para a captura do tucunaré, incluindo varas, linhas, grampos, molinetes, carretilhas e iscas artificiais. Enquanto 5\% gastam entre R\$ 100 a $\mathrm{R} \$ 600,00$ por dia em pescaria.

A faixa etária dos pescadores esportivos nacionais varia de 40 a 68 anos, sendo $85 \%$ do sexo masculino e $15 \%$ do sexo feminino. Estado civil: $75 \%$ casados e $25 \%$ união consensual. $75 \%$ possuem ensino superior completo; $60 \%$ ganham mais de 10 salários mínimos; $35 \%$ dos entrevistados praticam a pesca esportiva há mais de 20 anos, $35 \%$ entre 10 a 20 anos e $30 \%$ entre 1 a 10 anos. $40 \%$ dos respondentes têm uma frequência de pesca semestral; $25 \%$, mensal; $20 \%$, anual; $10 \%$, trimestral e $5 \%$ pescam quinzenalmente. As profissões são as mais diversas e são de origem do sul e sudeste do Brasil. 


\section{CONCLUSÃO}

Os resultados encontrados no presente estudo mostram que a capacidade de carga de pesca esportiva do Rio Água Boa do Univini, na região do baixo Rio Branco, no Estado de Roraima, Brasil foi estimada para os dois empreendimentos operando simultaneamente no rio em voga com 12 barcos motorizados com dois pescadores esportivos, totalizando 24 pessoas desfrutando da pesca (na área de estudo a pesca esportiva é embarcada). A metodologia de estimação da capacidade de carga para a pesca esportiva aplicada nesse trabalho, poderá ser estendida para outras regiões da Amazônia, propiciando informações mais robustas aos gestores e a sustentabilidade dos recursos pesqueiros, do ambiente amazônico e da própria atividade.

Esse quantitativo de 12 barcos motorizados contendo 24 pescadores esportivos contribui na percepção da necessidade de se fixar limite máximo de usuários na área, de forma que se possa ordenar e manejar as atividades ecoturísticas sem causar danos ao meio ambiente, evitando os impactos evitáveis e minimizando aqueles que são inevitáveis, proporcionando experiências sustentáveis vividas pelo pescador esportivo.

O efeito da influência das duas unidades de conservação existentes na área de estudo sobre as quatro espécies de tucunaré capturados no Rio Água Boa do Univini como fonte de reposição dos estoques pesqueiros não exerceram efeito diferenciado no tamanho, peso e número de total de peixes nas zonas de pesca ao longo do Rio Água Boa do Univini.

O perfil dos pescadores esportivos estrangeiros e nacionais que frequentam essa região do baixo Rio Branco, em especial, o Rio Água Boa do Univini, foi conhecido por meio da aplicação de questionários com informações sobre: idade, sexo, estado civil, escolaridade, renda mensal, tempo que pratica a pesca esportiva, frequência de pescaria, profissão, cidade/estado, valores gastos com pescaria, valores gastos com equipamento de pesca, itens mais investidos em pesca recreativa.

As informações coletadas no trabalho poderão contribuir para a construção de uma política sustentável de pesca esportiva para a sub-bacia do Rio Água Boa do Univini, extensível a outras áreas da Amazônia, através de estratégias de zoneamento de áreas de pesca e definição de cargas de exploração pela pesca esportiva embarcada. 


\section{REFERÊNCIAS}

ALBANO, Cícero José; VASCONCELOS, Eliane Carvalho de. Análise de casos de pesca esportiva no Brasil e propostas de gestão ambiental para o setor. Revista Brasileira de Ciências Ambientais - Número 28 - Junho de 2013. p 77-89. ISSN Impresso 1808-4524 / ISSN Eletrônico: 2176-9478.

ANDRETTA, Roald; FILHO, Homero Salazar; NOGUEIRA, Elizabete Melo; BRIGLIA, Thiago; FRANCO, José Gomes. Prospecção pesqueira rio Água Boa do Univini. Ministério do Meio Ambiente. Instituto Brasileiro do Meio Ambiente e dos Recursos Naturais Renováveis. Programa Nacional de Desenvolvimento da pesca Amadora. 16 a 21 de fevereiro de 2005. p. 24.

AROUCHE, Joyce Luana Santana; PINHEIRO, Kamilla Kelly Sales; CARVALHO, Thiago Morato. Um olhar geográfico das áreas suscetíveis a alagamentos na cidade de Caracaraí RR. III Congresso Brasileiro de Educação Ambiental Aplicada e Gestão Territorial. Manaus, 27 a 29 de Novembro de 2013. p.728-741. ISBN 978-85-7883-273-5.

ARLINGHAUS, R.; SCHWAB, A.; COOKE, S. J.; COWX, I. G. Contrasting pragmatic and suffering-centred approaches to fish welfare in recreational angling. Journal of Fish Biology (2009) 75, 2448-2463 doi:10.1111/j.1095-8649.2009.02466.x, available online at www.interscience.wiley.com

BARTHEM, R.B.; PETRERE Jr, M.; ISAAC, V.; RIBEIRO, M.C.L.B.; MACGRATH, D.G.; VIEIRA, I.J.A.; BARCO, M.V. A pesca na Amazônia: problemas e perspectivas para seu manejo. In: Padua CV, Bodmer RE. Manejo e Conservação de Vida Silvestre no Brasil. Instituto de Pesquisas Ecológicas. MCT. CNPq. Brasília p.173- 185. 1997.

FABRÉ, N.N. Biologia e diversidade dos recursos pesqueiros da Amazônia. Editora: Ibama/Provárzea. v.1. p. 17-62. 2004.

BARTHOLOMEW, Aaron; BOHNSACK, James A. A review of catch-and-release angling mortality with implications for no-take reserves. Reviews in Fish Biology and Fisheries (2005) 15: 129-154. DOI 10.1007/s11160-005-2175-1.

BARBOSA, R. I. 2005. Ecopaisagens do Parque Nacional "Serra da Mocidade" (Primeira Aproximação). Relatório Técnico. Ministério da Ciência e Tecnologia. Instituto Nacional de Pesquisa da Amazônia. Coordenação de Pesquisa em Ecologia. Base de Roraima. Boa Vista, RR. 31p.

BARNHART, R.A. (1989). Symposium review: catch-and-release fishing, a decade of experience. North American Journal of Fish Management, 9(1):74-80.

BARRONCO, Lorenzo Soriano Antonaccio. Taxa de mortalidade relacionada à prática da pesca esportiva do Cichla spp. Na região do médio rio Negro, Amazonas, Brasil. 2013. 45 f. 
Dissertação (Mestrado em Uso Sustentável de Recursos Pesqueiros Tropicais) - Universidade Federal do Amazonas, Manaus, AM, 2013.

BENSUSAN, Nurit. Conservação da Biodiversidade em Áreas Protegidas. Rio de Janeiro: Editora FGV, 2006. 176p.

BORGES, J.C.G., VERGARA-PARENTE, J.E., ALVITE, C.M.C., MARCONDES, M.C.C \& LIMA, R. P. Embarcações motorizadas: uma ameaça aos peixes-boi marinhos (Trichechus manatus) no Brasil. Biota Neotropica, v7 (n3) - bn03607032007. 2007. 199 - 2004p.

BRASIL, Lei Nº 6.902, de 27 de abril de 1981. Dispõe sobre a criação de Estações Ecológicas, Áreas de Proteção Ambiental e dá outras providências. Presidência da República, Casa Civil, Poder Executivo, Brasília, DF, 1981. Disponível em http://www.planalto.gov.br/ccivil_03/Leis/L6902.htm. Acesso em: 04 abr. 2019.

Decreto Nº. 91.306, de 3 de Junho de 1985. Cria a Estação Ecológica Niquiá em área de terra que indica, e dá outras providências. Legislação. Câmara dos Deputados. Brasília, DF, 1985. Disponível em: http://www2.camara.leg.br/legin/fed/decret/1980-1987/decreto91306-3-junho-1985-441991-publicacaooriginal-1-pe.html. Acesso em: 1 fev. 2019.

Decreto de 29 de abril de 1998. Cria o Parque Nacional Serra da Mocidade, no Estado de Roraima, e dá outras providências. Presidência da República, Casa Civil, Poder Executivo, Brasília, DF, $1998 . \quad$ Disponível em: http://www.planalto.gov.br/ccivil_03/DNN/Anterior\%20a\%202000/1998/Dnn29-04-98-

2.htm. Acesso em: 11 fev. 2019.

. Lei $\mathrm{N}^{\circ}$. 9.985, de 18 de julho de 2000. Regulamenta o art. 225, $\S 1^{\circ}$, incisos I, II, III e VII da Constituição Federal, institui o Sistema Nacional de Unidades de Conservação da Natureza e dá outras providências. Presidência da República, Casa Civil, Poder Executivo, Brasília, DF, 2000. Disponível em: http://www.planalto.gov.br/ccivil_03/LEIS/L9985.htm. Acesso em 11 fev. 2019.

Instrução Normativa N. 180, de 09 de julho de 2008. Estabelece Acordo de Pesca na Bacia do Baixo Rio Branco, na área localizada entre a vila de Vista Alegre (Paralelo N $1^{\circ} 44^{\prime}$ ) e a foz do Rio Branco (Paralelo $N^{\circ} 1^{\circ} 25^{\prime}$ ), no estado de Roraima, abrangendo os municípios de Caracaraí e Rorainópolis/RR. Brasília, DF, 2008. Disponível em: http://www.normasbrasil.com.br/norma/instrucao-normativa-180-2008_76913.html. Acesso em: 20 fev. 2019.

Lei $N^{o}$. 11.959, de 29 de junho de 2009. Dispõe sobre a Política Nacional de Desenvolvimento Sustentável da Aquicultura e da Pesca, regula as atividades pesqueiras, revoga a Lei $\mathrm{n}^{\circ} 7.679$, de 23 de novembro de 1988, e dispositivos do Decreto-Lei $\mathrm{n}^{\circ} 221$, de 28 de fevereiro de 1967, e dá outras providências. Brasília, DF, 2009. Disponível em:http://www.planalto.gov.br/ccivil_03/_Ato2007-010/2009/Lei/L11959.htm. Acesso em: 5 fev. 2019. 
Plano de Manejo. Estação Ecológica do Niquiá. Ministério do Meio Ambiente. MMA. Instituto Chico Mendes de Conservação da Biodiversidade. ICMBIO. Volume II. Brasília, DF, 2018.

Ministério do Turismo. Turismo de Pesca: orientações básicas. / Ministério do Turismo, Secretaria Nacional de Políticas de Turismo, Departamento de Estruturação, Articulação e Ordenamento Turístico, Coordenação Geral de Segmentação. - 2.ed. - Brasília: Ministério do Turismo, 2010. 58 p.; $24 \mathrm{~cm}$.

Ministério do Meio Ambiente. Estratégia de Desenvolvimento Sustentável do Ecoturismo do Estado de Roraima. Inventários dos atrativos e das Potencialidades Ecoturísticas. Secretaria de Coordenação da Amazônia. Programa de Desenvolvimento do Ecoturismo na Amazônia Legal. Relatório Final: Elaboração: Ruschmann Consultores, volume I. São Paulo, 2002.

Brasil Escola. Comprimento da circunferência e Área de um Círculo. 2019. Disponível em: https://brasilescola.uol.com.br/matematica/comprimento-Area-circunferencia.htm. Acesso em: 11 abr. 2019.

Caderno Nova Cartografia Mapeamento Social como Instrumento de Gestão Territorial contra o Desmatamento e a Devastação: processo de capacitação de povos e comunidades tradicionais. - N.9 (set.2014) - Manaus: UEA. Edições, 2014. V.:il; 30cm.

CARVALHO, T. M. 2012. Síntese dos aspectos Hidrogeomorfológico do Estado de Roraima. Zoneamento Ecológico Econômico do Estado de Roraima. Geomorfologia. Governo do Estado de Roraima / IACTI/ZEE.

CATELLA, Agostinho Carlos. Introdução aos modelos de produção excedente: uma ferramenta para o manejo pesqueiro / Agostinho Carlos Catella. - Corumbá: Embrapa Pantanal, 2004. 27p.; 16 cm. (Documentos / Embrapa Pantanal, ISSN 1517-1973; 64).

Reflexões sobre a pesca esportiva no Pantanal Sul: crise e perspectivas, 2004. Disponível em: https://www.infoteca.cnptia.embrapa.br/bitstream/doc/812672/1/ADM046.pdf. Acesso em: 29 Ago. 2018.

CIFUENTES, M. Determinación da capacidade de carga turística em áreas protegidas. Turrialba: CATIE, 1992. p. 18-35 (Série Técnica. Informe Técnico, 1994).

CIFUENTES, Miguel et al. Capacidad de Carga Turística de la Reserva Biologica Carara. Servicio de Parques Nacionales. Programa de Manejo Integrado de Recursos Naturales. Centro Agronomico Tropical de Investigación Y Enseñanza (CATIE), 1990. p. 1-52.

CORDEIRO, Itamar Dias; KÖRÖSSY, Nathália; SELVA, Vanice Santiago Fragoso. Capacidade de carga recreativa para embarcações: O caso da Área de Proteção Ambiental de Guadalupe. Revista de Investigación en Turismo y Desarrollo Local. Vol.6, N.14 (Junio/junho 2013). p.1-22. 2013. 
. Determinação da Capacidade de Carga Turística a partir do Método Cifuentes et al. (1992): Aplicação à Praia dos Carneiros (Tamandaré/PE). Revista Turismo Visão e Ação Eletrônica, Vol. 15 - nº 1 - p. 57-70 / jan-abr 2013.

COOKE, S. J.; COWX, I. G. The Role of Recreation Fishimg in Global Fish Crises. BioScience, Vol. 54; $n^{\circ}$ 9. p. 857 - 859, 2004.

Contrasting Recreational and Commercial Fishing: Searching for common issues to promote unified conservation of Fisheries Resources and Aquatic Environments. Biological Conservation. 128 (2006) 93-128.

COOKE, Steven J.; SUSKI, Cory D. Do we need species specific guidelines for catch-andrelease recreational angling effectively conserve diverse fishery resources? Biodiversity and Conservation 14: 1195-1209, 2005. Springer 2005 DOI 10.1007/s10531-004-7845-0.

Classificação climática de Köppen- Geiger. Disponível em: https://www.passeidireto.com/arquivo/37447782/classificacao-climatica-de-koppen/2. Acesso em: 15 Maio 2019.

CHAVES, Paulo de Tarso; FREIRE, Kátia Meirelles Felizola. A pesca esportiva e o pesquee-solte: pesquisas recentes e recomendações para estudos no Brasil. Bioikos, Campinas, 26(1):29-34, jan./jun., 2012.

CRAVEIRO, Juliana Rodrigues Venturi. Caracterização das Unidade de Conservação: Referências sobre o Sistema Nacional de Unidades de Conservação da Natureza. 2008. 13p. Disponível em: http://observatoriogeograficoamericalatina.org.mx/egal12/Procesosambientales/Impactoambie ntal/87.pdf. Acesso em: 27 fev. 2019.

CREPALDI, D. V. Avaliação rápida dos estoques de Cicla no rio Água Boa do Univini e proposição de medidas de gestão. Ministério do Meio Ambiente. Instituto Brasileiro do Meio Ambiente e dos Recursos Naturais Renováveis. Diretoria de Biodiversidade e Floresta. Coordenação de Recursos Pesqueiros. Relatório Técnico. Belo Horizonte, 2014.

DIAS NETO, José Colaço Dias. Quanto custa ser pescador artesanal? Etnografia, relato e comparação entre dois povoados pesqueiros no Brasil e em Portugal / José Colaço Dias Neto. - 1.ed. - Rio de Janeiro: Garamond, 2015. 316p.

DITTON, R. B.; HOLLAND, S. M.; ANDERSON, D. K. Recreational fishing as tourism. Fisberies, 27 (3): 17-24, Mar. 2002.

ESTEVES, F. de. A. Gênese dos Ecossistemas Lacustres. In: Fundamentos de limnologia / Francisco de Assis Esteves (coordenador). - 3. ed. Rio de Janeiro: Interciência, 2011, p. 83 107.

Equipe de Recursos Pesqueiros da Embrapa Pantanal. Uso múltiplo dos recursos pesqueiros como estratégia para conservação. Caderno de Resumos do I Simpósio Nacional de Pesca Esportiva. I SINPE. Belém, 29/11/2011, Belém - PA, p.10-13.

FABRI, J.B. 2006. Pesca. In: DACOSTA, L. (org.) Atlas do Esporte no Brasil. CONFEF, Rio de Janeiro, Cap. 10. p. 9-12. 
FERREIRA, Sylvio Romério Briglia; RÖPKE, Cristhiana Paula; ALVES-GOMES, José A. Ictiofauna da região da serra da lua (Roraima, Brasil) e importância dos ambientes aquáticos de 'lavrado' no interflúvio das bacias dos rios Negro, Essequibo e Orinoco. In: Amazônia: terra e água degradação e desenvolvimento sustentável / Organizadores, Francisco Capuano Scarlato, Renato Augusto de Oliveira Evangelista, Wellington Farias Araújo. - Boa Vista: Editora da UFRR, 2012. 208p.

FERREIRA, Efrem; ZUANON, Jansen; FORSBERG, Bruce; GOULDING, Michael; BRIGLIA-FERREIRA, Sylvio Romério. RIO BRANCO: Peixes, Ecologia e Conservação de Roraima. Gráfica Biblos. 2007. 201p.

FILHO, Homero de Oliveira Salazar; ANDRETTA, Roald Antônio; NOGUEIRA, Elizabete Melo. Diagnóstico preliminar do potencial de desenvolvimento da atividade de pesca esportiva na região do Baixo Rio Branco, Estado de Roraima. Boletim Técnico-Científico do CEPNOR. Belém. v.5, n.1, p.173-195. 2005.

FORMAN, R. T. T.; GODRON, M. Landscape Ecology. New York, John Wiley \& Sons, 1986, 619p.

FREITAS, C. E. C.; RIVAS, A. A. F. A pesca e os recursos pesqueiros na Amazônia Ocidental. Fonte. Ciênc. e cult. (São Paulo); 58 (3): 30-32. jul/set. 2006.

FREIRE, K. M. F.; TUBINO, R. A.; MONTEIRO-NETO, C.; ANDRADE-TUBINO, M. F.; BELRUSS, C. G.; TOMÁS, A. R. G.; TUTUI, S. L. S.; CASTRO, P. M. G.; MARUYAMA, L. S.; CATElla, A. C.; CREPALDI, D. V.; DANIEL, C. R. A.; MACHADO, M. L.; MENDONÇA, J. T.; MORO, P. S.; MOTTA, F. S.; RAMIRES, M.; SILVA, M. H. C.; VIEIRA, J. P. Brazilian recreational fisheries: current status, challenges and future direction. Fisheries Management and Ecology, 2016. p. 1-15. Doi: 10.1111/fme.12171.

FROESE R. \& PAULY D. (2015) FishBase. Version 10/2015. Available at: www.fishbase.org. Accessed in December 2015.

GASQUES, L. S.; FABRIN, T. M. C.; PRIOLI, S. M. A. P.; PRIOLI, A. J. A introdução do gênero Cichla [Block e Schneider, 1801] na planície de inundação do Alto Rio Paraná. Arq. Ciênc. Vet. Zool. UNIPAR, Umuarama, v. 17, n. 4, p. 261-266, out./dez. 2014.

GRANEK, E. F; MADIN, E. M. P; BROWN, M. A; FIGUEIRA, W; CAMERON, D. S; HOGAN, Z; DRISTIANSON, G., et al. 2008. Engaging recreational fishers in management and conservation: global case studies. Conservation Biology, 22: 1125-1134.

GOODE, Willam Josiah. Métodos em Pesquisa Social. $7^{\text {a }}$ ed. São Paulo: Editora Nacional, 1979.

HAGAR, J. Alan. The Carrying Capacity of Wild Lands for Recreation. A Publication of the Society of American Foresters. Forest Science. Monograph 7. Washington. D.C. 1964.

HENRY, Lesjak Martos; MARIA YVONNE, Haddad Galvão Martos. Turismo de Pesca. In: Análises regionais e globais do turismo brasileiro / editor Luiz Gonzaga Godoi Trigo; coeditores Alexandre Panosso Netto, Mariana Aldrigui Carvalho, Paulo dos Santos Pires. - São Paulo: Roca, 2005. 
HORIE, Cesar Augusto Chirosa. Biologia reprodutiva e estrutura da população do tucunaré Cichla vazzoleri (Perciformes: Cichlidae) no Reservatório da Hidrelétrica de Balbina, Amazonas, Brasil / Cesar Augusto Chirosa Horie. --- Manaus : [s.n], 2014. xi, 67 f. : il. color.

HOLLEY, M. H.; MACEINA, M. J.; THOMÉ-SOUZA, M.; FORSBERG, B. R. Analysis of the trophy sport fishery for the speckled peacock bass in the Rio Negro River, Brazil. Fisheries Management and Ecology, v.15, n. 2, p. 93-98, 2008.

IBAMA. Portaria $\mathrm{n}^{\mathbf{0}}$ 4, de 19 de março de 2009. Disponível em: http://sinpesq.mpa.gov.br/rgp_cms/images/publico/legislacao/portariaibama042009.pdf.

Acesso em: 29 Ago. 2018.

IBGE. 2017. Disponível em: https://cidades.ibge.gov.br/brasil/rr/caracarai/panorama. Acesso em: 13 Ago. 2019.

Junk, W., P.B. Bayley, and R.E. Sparks. 1989. The flood pulse concept in river-floodplain systems. Pages 110-127 in D.P. Dodge, ed. Proceedings of the International Large River Symposium (LARS). Canadian Special Publication of Fisheries and Aquatic Sciences 106.

KELBER, Dieter. Tucunaré, uma paixão internacional / Dieter Kelber - São Paulo: Arte \& Ciência, 1999. 96p.; 21 cm. - (Coleção Pescarte).

KULlAnDER, S. O. 2003. Cichlidae. Pp.605-654. In: Reis, R. E., S. O. Kullander \& C. J. Ferraris, Jr., (eds.), Check list of the freshwater fishes of South and Central America. Edipucrs, Porto Alegre, 729 pp.

FERREIRA, EFREM. J. G. A review of the South American cichlid genus Cichla, with descriptions of nine new species (Teleostei: Cichlidae). Ichthyological Exploration Freshwaters. Vol. 17, No. 4, pp. 289-398, 93 figs., 27 tabs., December 2006 @ 2006 by Verlag Dr. Friedrich Pfeil, München, Germany - ISSN 0936-9902.

LADEIRA, Luiz Felipe Brandão; DANTAS, Marcelo Eduardo. Compartimentação Geomorfológica. CPRM - Serviço Geológico do Brasil. p. 33-46. 2014.

LAKATOS, Eva Maria. Fundamentos de metodologia científica / Marina de Andrade Marconi, Eva Maria Lakatos. - 5. ed. - São Paulo: Atlas 2003.

MATEUS, Lúcia A. F.; PENHA, Jerry M. F. Avaliação dos estoques pesqueiros de quatro espécies de grandes bagres (Siluriformes, Pimelodidae) na bacia do rio Cuiabá, Pantanal norte, Brasil, utilizando alguns Pontos de Referência Biológicos. Revista Brasileira de Zoologia 24(1): 144-150, março 2007.

MEDAUAR, Odete (Organizadora). Constituição Federal - Coletânea de Legislação de Direito Ambiental. 5a ed. São Paulo: Editora Revista dos Tribunais, 2006.

MELO, Rodrigo de Sousa; CRISPIM, Maria Cristina; LIMA, Eduardo Rodrigues Viana de; NISHIDA, Alberto Kioharu. Estimativa da capacidade de carga recreativa dos ambientes recifais da Praia do Seixas (Paraíba - Brasil). Turismo - Visão e Ação - vol.8 - n.3 p.411422 set./dez. 2006. 
MÉRONA, Bernard. Ecologia da pesca e manejo pesqueiro na Região Amazônica. Bol. Mus: Para. Emílio Goeldi, sér. Antropal. II (2), 1995.

MORAIS, Roseane Pereira; CARVALHO, Thiago Morato de. Cobertura da Terra e Parâmetros da Paisagem no Munícipio de Caracaraí - Roraima. Revista Geográfica Acadêmica. v, 7, n. 1, p. 46-59. 2013.

MITRAUD, S. (2003): Monitoramento e controle de impactos de visitação. En MITRAUD, S. (org.). Manual de ecoturismo de base comunitária: ferramentas para um planejamento responsável. WWF Brasil. Brasília, p.315-362.

MUELRATH, SCOTT; MUELRATH, DON. Fly Fishing's Greatest Adventures. The Hunt. Edição Amazônia, 182p. 2012.

O'TOOLE, Amanda. C.; DANYLCHUK, ANDY J.; SUSKI, Cory D.; COOKE, Steven J. Consequences of catch-and-release angling on the physiological status, injury, and immediate mortality of great barracuda (Sphyraena barracuda) in The Bahamas. - ICES Journal of Marine Science, 67: 1667-1675. 2010.

OLIVEIRA, B. (2017). A arte e as moscas do fly. In: Bíblia do pescador: O maior guia de iscas artificiais do Brasil. 28 anos. GR Um Editora Ltda. São Paulo, SP. p. 48 - 56. 2017.

PRODANOV, Cleber Cristiano. Metodologia do trabalho científico [recurso eletrônico] : métodos e técnicas da pesquisa e do trabalho acadêmico / Cleber Cristiano Prodanov, Ernani Cesar de Freitas. - 2. ed. - Novo Hamburgo: Feevale, 2013.

PETRERE Jr, Miguel. Pesque-Solte: Proteção ou dano para os peixes? CIÊNCIA HOJE, vol. 53, n. 317, p. 16-19, Agosto 2014.

POLICANSKY, D. (2008). Trends and developments in catch-release. In: Aas O. (Ed.). Global challenges in recreational fisheries. Oxford: Blackwell Publishing.

PHILIPPSEN, Juliana Strieder, 1984 - Avaliação de estoques pesqueiros do reservatório de Itaipu por meio das abordagens uni-específica e ecossistêmica. 2017. 185 f. Tese (Doutorado em Ciências Ambientias) - Programa de Pós-Graduação em Ecologia de Ambientes Aquáticos Continentais) - Universidade Estadual de Maringá, Paraná, 2017.

PROENÇA, Wander de Lara. O Método da Observação Participante: Contribuições e aplicabilidade para pesquisas no campo religioso brasileiro. Organização: Karina K. Bellotti e Mairon Escorsi Valério. Revista Aulas. Dossiê Religião. N.4-abril 2007/junho 2007. 24p. 2007.

PRINCE'S, Taff. Fish of the Água Boa. Identification Guide to the Fish Species of the Rio Água Boa. [S.I.: s.n.]. [2009]. 37p.

REISS, P. et al. Color pattern variation in Cichla temensis (Perciformes: Cichlidae): Resolution based on morphological, molecular, and reproductive data. Neotropical Ichthyology, v. 10, n. 1, p. 59-70, Jan-Mar 2012. ISSN 1679-6225. 
REIS, R.E.; ALBERT, J. S.; DI DARIO, F.; MINCARONE, M.M.; PETRY, P.; ROCHA, L. A. Fish biodiversity and conservation in South America. Journal of Fish Biology (2016). 138. DOI: 10.1111/jfb.13016, available online at wileyonlinelibrary.com.

RORAIMA. Portaria Normativa Nº. 001/2011, 06 de Dezembro de 2011. Diário Oficial do Estado de Roraima. Poder Executivo, Boa Vista, RR, 19 dez. 2011. No. 1690. p. 14.

RUFFINO, Mauro Luis. Gestão do uso dos recursos pesqueiros na Amazônia / Mauro Luis Ruffino. - Manaus: Ibama, 2005. 135p.; 23 cm.

RUSCHMANN, D. Turismo e planejamento sustentável. Campinas: Papirus, 1999. 199 p.

RUSCHMANN, Doris V. De M; PAOLUCCI, Luciana; MACIEL, Nelson A. L. Capacidade de carga no Planejamento Turístico: Estudo de Caso da Praia Brava - Itajaí frente a implantação do Complexo Turístico Habitacional Canto da Brava. Revista Brasileira de Pesquisa em Turismo. n.2, v.2, p. 41 - 63, jul. 2008.

SANTOS, Geraldo Mendes dos; SANTOS, Ana Carolina Mendes dos. Sustentabilidade da pesca na Amazônia. Estudos Avançados (19) 54, 2005. p. 165-182.

SAINT-PAUL, Ulrich; BAYLEY, Peter, B. A situação da pesca na Amazônia Central. SUPLEMENTO ACTA AMAZÔNICA 9(4): 109-114. 1979.

SILES, Maria Francisca Roncero. Modelagem espacial para atividades de visitação pública em áreas naturais. 2003. 134p. Dissertação (Mestrado em Ciências, área de Ecologia). Instituto de Biociências da Universidade de São Paulo. São Paulo, SP. 2003.

SIOLI, Harald. 1950 - Das Wasser im Amazonasgebiet. Forschung und Fortschritte, 21/22: 274-280.

50.

.1967. Studies in Amazonian waters. Atas do Simpósio sobre a Biota Amazónica, 3: 9-

SILVA, E. I.; LIMA, I. B. O potencial econômico e turístico da pesca esportiva na Amazônia setentrional. Revista Brasileira de Ecoturismo, São Paulo, v.7, n.4, nov2014-jan2015, p.779-804.

SILVA JÚNIOR, Urbano Lopes da; RASEIRA, Marcelo Bassols; RUFFINO, Mauro Luis; BATISTA, Vandick da Silva; LEITE, Rosseval Galdino. Estimativas do Tamanho do Estoque de algumas Espécies de Peixes Comerciais da Amazônia a partir de Dados de Captura e Esforço. Biodiversidade Brasileira, 7(1): 105-121, 2017.

SOBREIRO, T.; FREITAS, C.E.C. Conflitos e territorialidade no uso de recursos pesqueiros do Médio rio Negro. IV Encontro da Associação Nacional de Pesquisa e Pós-Graduação em Ambiente e Sociedade. Brasília-DF, 2008.

SOUZA, R. O. de.; GUTERES, L. F. dos R., BARROCO, L. S. A.; MONTEIRO, E. A.; FREITAS, C. E. de C. Pesca amadora/esportiva na Amazônia: potencial de desenvolvimento e análise de suas sustentabilidade ecológica e econômica. In: Silveira Edson Damas da (coord.) Socioambientalismo de fronteiras: relações homem-ambiente na Amazônia. I coordenação Edson Damas da Silveira, Serguei Aily Franco de Camargo. / Curitiba: Juruá, 2014. 238p. - v. 3. 
SOUZA, Flávia Domitila de Lima; CAÑETE, Voyner Ravena. Pesca esportiva e pesca artesanal: lazer e sobrevivência na Hidrelétrica de Tucuruí (PA). Revista Brasileira de Ecoturismo, São Paulo, v.8, n.5, nov-2015/jan-2016, pp. 614-633.

SPARRE, P.; VENEMA, S. C. Introdução à avaliação de mananciais de peixes tropicais. Parte I: Manual. FAO Documento Técnico sobre as Pescas. No. 306/1. Rev.2. Roma, FAO. 1997. 404p.

TUFTS, B.L.; DAVIDSON, K. \& BIELAK, A.T. (2000). Biological implications of "catch and release" angling of Atlantic Salmon. In: Whoriskey Jr., F.G. \& Whelan, K.E. (Ed.). Managing Wild Atlantic Salmon: new challenges - new techniques. Proceedings of the 5th International Atlantic Salmon Symposium, 1997, Ireland. p.195-227.

THOMÉ-SOUZA M.J.F; MACEINA M.J; FORSBERG B.R; MARSHALL B.G. \& CARVALHO A.L. (2014) Peacock bass mortality associated with catch-and-release sport fishing in the Negro River, Amazonas State, Brazil. Acta Amazonica 44, 527-532.

VALE JÚNIOR, José Frutuoso do. Solos sob savanas de Roraima: gêneses, classificação e relação e relações ambientais / José Frutuoso do Vale Júnior, Carlos Ernesto Gonçalves Reynaud Schaefer. - Boa Vista: Gráfica Ioris, 2010. 219 p. : il.

VAZ, Luciano Jensen. Produção e transporte do camarão-rosa Farfantepenaeus brasiliensis para a pesca amadora: uma alternativa sustentável? 2012. 133f. Tese (Doutorado em Ciências, área de Ecologia e Recursos Naturais). Centro de Ciências Biológicas e da Saúde. Universidade Federal de São Carlos, SP. 2012.

VITÓRIO, L. de. S. Turismo de base comunitária: análise quanto às interferências do turismo de pesca no Baixo Rio Branco, Roraima, Brasil. 2014. 132f. Dissertação (Mestrado em Turismo). Universidade de Caxias do Sul. Rio Grande do Sul.

VIOLI, Joseane. Estudo de Impacto Ambiental e Capacidade de Carga na Trilha do Paraíso, Situada na Serra do Japi, Jundiaí, SP, Brasil. Turismo em Análise, v. 16, n. 2, p. 223-243, novembro 2005.

ZEINAD, A.K. \& PRADO R.A. (2012) Peixes fluviais do Brasil. Campinas: Pescaventura, $360 \mathrm{pp}$. 


\section{APÊNDICES}

Apêndice A - Instrumento de pesquisa I (questionário - guias de pesca)

Poder Executivo

Ministério da Educação

Universidade Federal do Amazonas

Faculdade de Ciências Agrárias

Programa de Pós-Graduação em Ciências Pesqueiras nos

Trópicos PPGCIPET

\section{ANOTACÕES DOS GUIAS SOBRE A PESCARIA}

Data:

Hora:

Local do lago:

Nome do lago:

Periodo de pesca:

Manhã: inicio às até às

Tarde: inicio às até às

Espécie de peixe:

Tamanho (cm):

Peso (kg):

Nome do Guia:

Tempo que atua como guia de pesca:
( ) Menos de 1 ano
( ) Entre 1 a 5 anos
( ) Entre 5 a 10 anos
( ) Entre 10 a 15 anos
( ) Mais de 15 anos

Atua somente com a atividade de pesca:

( ) Sim

( ) Não 
Apêndice B - Instrumento de pesquisa II (questionário - pescadores nacionais)

Poder Executivo

Ministério da Educação

Universidade Federal do Amazonas

Faculdade de Ciências Agrárias

Programa de Pós-Graduação em Ciências Pesqueiras nos

UFAM Trópicos PPGCIPET

\section{QUESTIONÁRIO}

Prezado pescador esportivo

Estamos realizando um estudo intitulado "Capacidade de carga de pesca esportiva no rio Água Boa do Univini na região do baixo rio Branco - Roraima Brasil". A finalidade deste estudo é construir o conhecimento necessário para o desenvolvimento de uma pesca esportiva sustentável. Esse levantamento pretende identificar o perfil dos pescadores esportivos que atuam na região. Esta pesquisa faz parte da Tese de Doutorado de Robson Oliveira de Souza sob orientação do Professor Dr. Carlos Edwar de Carvalho Freitas, do Programa de Pós-Graduação de Ciências Pesqueiras nos Trópicos (CIPET), da Universidade Federal do Amazonas (UFAM).

A contribuição de todos será fundamental para a definição de políticas públicas realistas, que reconhecem a viabilidade da pesca esportiva como uma atividade sustentável e que venha a contribuir para o desenvolvimento regional e a melhoria da qualidade de vida dos povos da Amazônia.

Todas as informações serão sigilosas e serão de uso exclusivo para a realização da pesquisa, da Tese de Doutorado ou de relatórios ou artigos que dela resultarem.

Agradecemos, desde já, por sua colaboração ao participar da pesquisa.

O questionário deverá ser devolvido ao pesquisador após o preenchimento. 
Poder Executivo

Ministério da Educação

Universidade Federal do Amazonas

Faculdade de Ciências Agrárias

Programa de Pós-Graduação em Ciências Pesqueiras nos

UFAM Trópicos PPGCIPET

PERFIL DO PESCADOR ESPORTIVO E DA PESCARIA:

$\mathrm{N}^{\circ}$

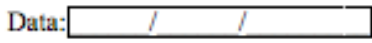

Idade: anos Sexo: ( ) M ( ) F

Estado Civil: ( ) solteiro ( ) casado ( ) união consensual ( ) viúvo ( ) separado

Escolaridade: ( ) Ensino Fundamental incompleto

( ) Ensino Fundamental completo

( ) Ensino Médio incompleto

( ) Ensino Médio completo

( ) Ensino Superior incompleto

( ) Ensino Superior completo

( ) Especialista

( ) Mestrado

( ) Doutorado

Renda mensal: ( ) 1 salário ( ) 5 salários ( ) 10 salários ( ) $>10$ salários

Tempo que pratica a pesca esportiva/amadora:
( ) Menos de 1 ano
( ) Entre 1 a 10 anos
( ) Entre 10 a 20 anos
( ) Mais de 20 anos

Frequência de pescaria:
( ) Semanal
( ) Quinzenal
( ) Mensal
( ) Semestral
( ) Anual

Profissão:

Estado e pais em que reside:

Cidade:

Estado:

Pais: 
Poder Executivo

Ministério da Educação

Universidade Federal do Amazonas

Faculdade de Ciências Agrárias

Programa de Pós-Graduação em Ciências Pesqueiras nos Trópicos PPGCIPET

\section{Características físicas da embarcação de pesca}

Tipo: ( ) barco motorizado

Material do casco: ( ) aluminio ( ) fibra ( ) outro:

Comprimento: total $\quad \mathrm{m}$ boca $\quad \mathrm{m}$ pontal $\quad \mathrm{m}$

Motor: marca __ potência __ HP

Combustivel: ( ) diesel ( ) gasolina

\section{Características das pescarias}

Tipo de pesqueiro: Rio ( ) Lago ( ) Igarapé ( ) Igapó ( ) Praia ( ) Enseada ( )

Boca ( ) Capim ( ) Furo ( )

Número de pescadores por embarcação: ( ) Um ( ) Dois ( ) Três ( ) Quatro

Duração da viagem de pesca para chegar em cada área:

Horário de saida da base de apoio

Horário de chega na base de apoio

Quantos dias pescando: ( ) Quatro ( ) Cinco ( ) Seis ( ) sete

Quantas horas por dia: ( ) Duas ( ) Três ( ) Quatro ( ) Cinco

( ) Seis ( ) Sete ( ) Oito

Quantas pescarias por semana:

Qual o peso dos peixes:

Qual o comprimento dos peixes:

Valores gastos com pescaria:
( ) Entre R\$ 100,00 a RS $150,00 /$ dia
( ) Entre R\$ 150,00 a RS 300,00/dial
( ) Entre R\$300,00 a RS 500,00/dia
( ) Entre R\$ 500,00 a RS 600,00/dia
( ) Acima de RS 600,00/dia 
Poder Executivo

Ministério da Educação

Universidade Federal do Amazonas

Faculdade de Ciências Agrárias

Programa de Pós-Graduação em Ciências Pesqueiras nos Trópicos PPGCIPET

Valores gastos com equipamento de pesca:

( ) Menos de R\$500,00 a RS $1.000,00 /$ ano

( ) Entre R\$1.000,00 a RS 2.000,00/ano

( ) Entre R\$2.000,00 a RS 5,000,00/ano

( ) Entre R\$5.000,00 a RS $10.000,00 / a n o$

( ) Acima de RS 10.000,00/ano

Em quais itens de pesca você investe mais:
( ) Carretilha
( ) Molinete
( ) Iscas artificiais
( ) Linhas de multifilamento
( ) Caniço
( ) Vestuário
( ) Outros:

Pesca com: carretilha ( ) molinete ( ) Fly ( )

Tipo de isca utiliza na pescaria:
( ) Isca artificial de superficie
( ) Subsuperficie com ou sem barbelas
( ) isca artificial de meia água

Tipos de linha de pesca:
( ) Convencional - nylon
( ) Monofilamento
( ) Multifilamento

Principal espécie que busca capturar quando pratica a pesca esportiva:
( ) Tucunaré-açu
( ) Tucunaré paca
( ) Tucunaré borboleta
( ) Tucunaré popoca
( ) Outras: 
Apêndice C - Instrumento de pesquisa III (questionário - pescadores estrangeiros)

Poder Executivo

Ministério da Educação

Universidade Federal do Amazonas

Faculdade de Ciências Agrárias

Programa de Pós-Graduação em Ciências Pesqueiras nos

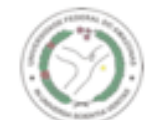

UFAM Trópicos PPGCIPET

\section{STRUCTURED QUESTIONNAIRE}

Dear sports fisherman

We are conducting a study entlitled "Load capacity of sport fishing on the Água Boa do Univini river in the region of the lower Rio Branco - Roraima Brasil". The purpose of this study is to build the necessary knowledge for the development of a sustainable sport fishing. This survey intends to identify the profile of the sport fishermen who work in the region. This research is parto $f$ the Doctoral Thesis of Robson Oliveira de Souza under the guidance of Professor Doctor Carlos Edwar de Carvalho Freitas, of the Postgraduate Program in Fisheries in the Tropics (CIPET), Federal University of Amazonas (UFAM).

The contribution of all will be fundamental for the definition of realistic public policies, which recognize the viability of sport fishing as a sustainable activity and that contributes to regional development and improving the quality of life of the peoples of the amazon.

All information will be confidential and will be used exclusively for the conduct of the research, of the $\mathrm{PhD}$ thesis oro f reports or articles resulting from it.

We thank you in advance for your participation in the research.

The questionnaire should be returned to the researcher after completion.

PROFILE OF SPORTS FISHERMAN AND FISHERIES: 
Poder Executivo

Ministério da Educação

Universidade Federal do Amazonas

Faculdade de Ciências Agrárias

Programa de Pós-Graduação em Ciências Pesqueiras nos Trópicos PPGCIPET

$\mathrm{N}^{\circ}$

Date:

Age: ans $\operatorname{Sex}:($ ) M ( ) F

Marital status: ( ) not married ( ) married ( ) consensual union ( ) widower ( ) separate

Education: ( ) Incomplete elementary school

( ) Complete primary education

( ) Incomplete high school

( ) Complete high school

( ) Incomplete higher education

( ) Complete higher education

( ) Specialist

( ) Master

( ) Doctorate degree

Monthly income: ( ) 1 salary ( ) 5 salary ( ) 10 salary ( ) $>10$ salary

Time that you practice sports / amateur fishing:

( ) Less than 1 year

( ) Between 1 and 10 years

( ) Between 10 and 20 years

( ) More than 20 years

Fishing frequency
() Weekly
( ) Fortnightly
( ) Monthly
( ) Semester
( ) Yearly

Profession:

State and country of residence:

Citye:

State:

Country: 
Poder Executivo

Ministério da Educação

Universidade Federal do Amazonas

Faculdade de Ciências Agrárias

Programa de Pós-Graduação em Ciências Pesqueiras nos Trópicos PPGCIPET

\section{Characteristics of fisheries}

Type of fishing: River ( ) Lake ( ) Igarapé ( ) Igapó ( ) Beach ( ) Cove ( ) Mouth ( ) Grass ( ) Hole ( )

Number of fishermen per vessel: ( ) One ( ) Two ( ) Three ( ) Four

Duration of fishing trip to arrive in each area:

Departure time of the support base

Time to arrive at the support base

How many days fishing?: ( ) Four ( ) Five ( ) Six ( ) Seven

Quantas horas por dia: ( ) Two ( ) Three ( ) Four ( ) Five

( ) Six ( ) Seven ( ) Eight

How many fisheries per week:

What is the weight of fish:

How long are the fish:

Amounts spent on fishery:
( ) Between USS 25 and US\$ 35 / day
( ) Between USS 35 and US\$ $73 /$ day
( ) Between USS 73 and US\$121/day
( ) Between USS 121 and US\$145/day
( ) Above USS 600,00/ day

Amounts spent on fishing equipment:

( ) Less than US\$121 to US\$243/ year

( ) Between USS 243 and US\$ 484 /year

( ) Between USS 484 and US\$ 1,207/year

( ) Between USS 1.207 and US\$2,415/year

( ) Above $R \$ 2,415 /$ year

In which fishing items do you invest more:
( ) Reel
( ) Windlass
( ) Artificial baits
( ) Multifilament Lines 
Poder Executivo

Ministério da Educação

Universidade Federal do Amazonas

Faculdade de Ciências Agrárias

Programa de Pós-Graduação em Ciências Pesqueiras nos

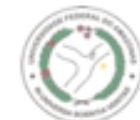

UFAM Trópicos PPGCIPET
( ) Reed
( ) Clothing
( ) Others:

Fishing with: Reel ( ) Windlass ( ) Fly ( )

Type of bait used in fishery:

( ) Artificial surface bait

( ) Subsurface with or without barbels

( ) Half-water artificial bait

Types of fishing line:

( ) Conventional - nylon

( ) Monofilament

( ) Multifilament

Main species that seeks to capture when practicing sport fishing:
( ) Tucunaré-açu
( ) Tucunaré paca
( ) Tucunaré borboleta
( ) Tucunaré popoca
( ) Others: 
Apêndice D - Instrumento de pesquisa IV (Cartilha: Fotografe o seu troféu)

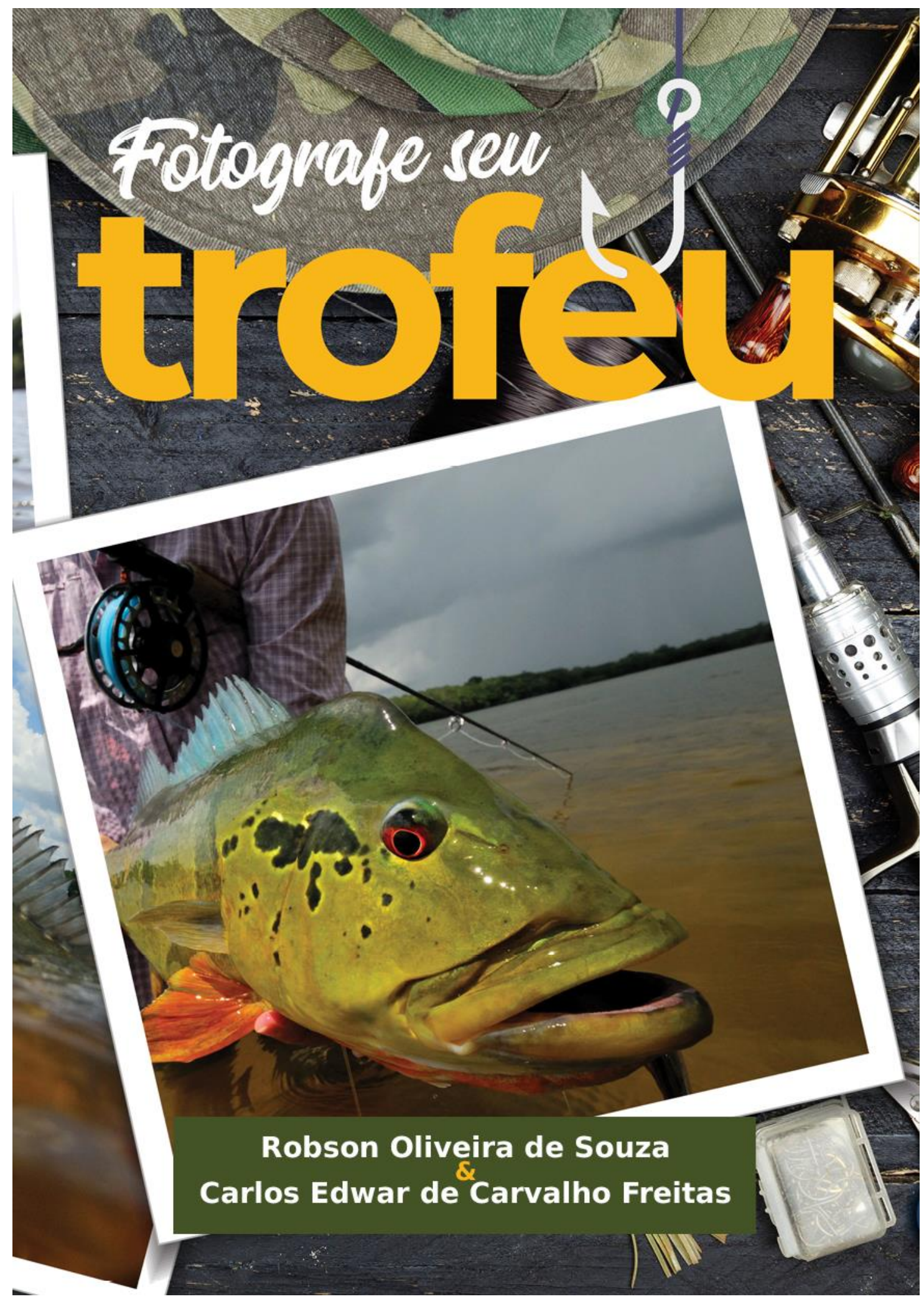




\section{Robson Oliveira de Souza}

Doutorando do Programa de Pós- Graduação em Ciências Pesqueiras nos Trópicos - CIPET pela Universidade Federal do Amazonas - UFAM, AM. Bolsista da CAPES. Mestre em Produção Vegetal pela Universidade Federal de Santa Maria - UFSM, RS. Graduado em Agronomia pela Universidade Federal de Santa Maria - UFSM, RS. Professor do Curso de Graduação em Agronomia da Universidade Estadual de Roraima UERR, RR.

\section{Carlos Edwar de Carvalho} Freitas

Pós-Doutor em 2009, na Washington and Lee University (USA). Doutor em Ciências da Engenharia Ambiental pela Universidade de São Paulo, USP, SP. Mestre em Biologia de Água Doce e Pesca Interior pelo Instituto Nacional de Pesquisa da Amazônia - INPA, AM. Graduado em Engenharia de Pesca pela Universidade Federal do Ceará, UFC, CE. Professor Titular da Universidade Federal do Amazonas- UFAM. Professor Credenciado do Instituto Nacional de Pesquisa da Amazônia INPA. Bolsista de produtividade em pesquisa do CNPq, Glynn Visiting International Scholar and Full Professor of Environmental Studies at the Washington and Lee University (USA). Fellow of the Linnean Society of London. 


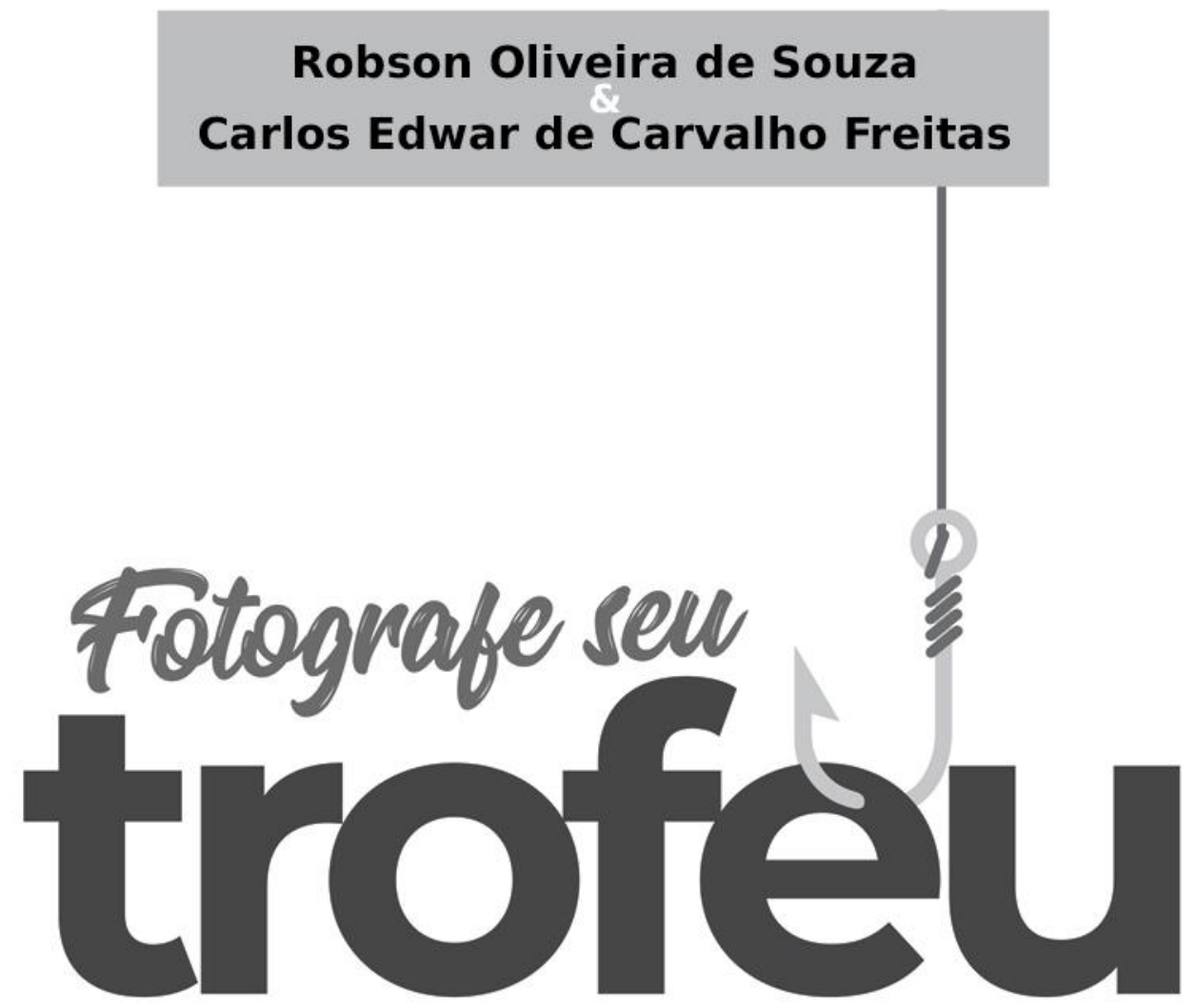




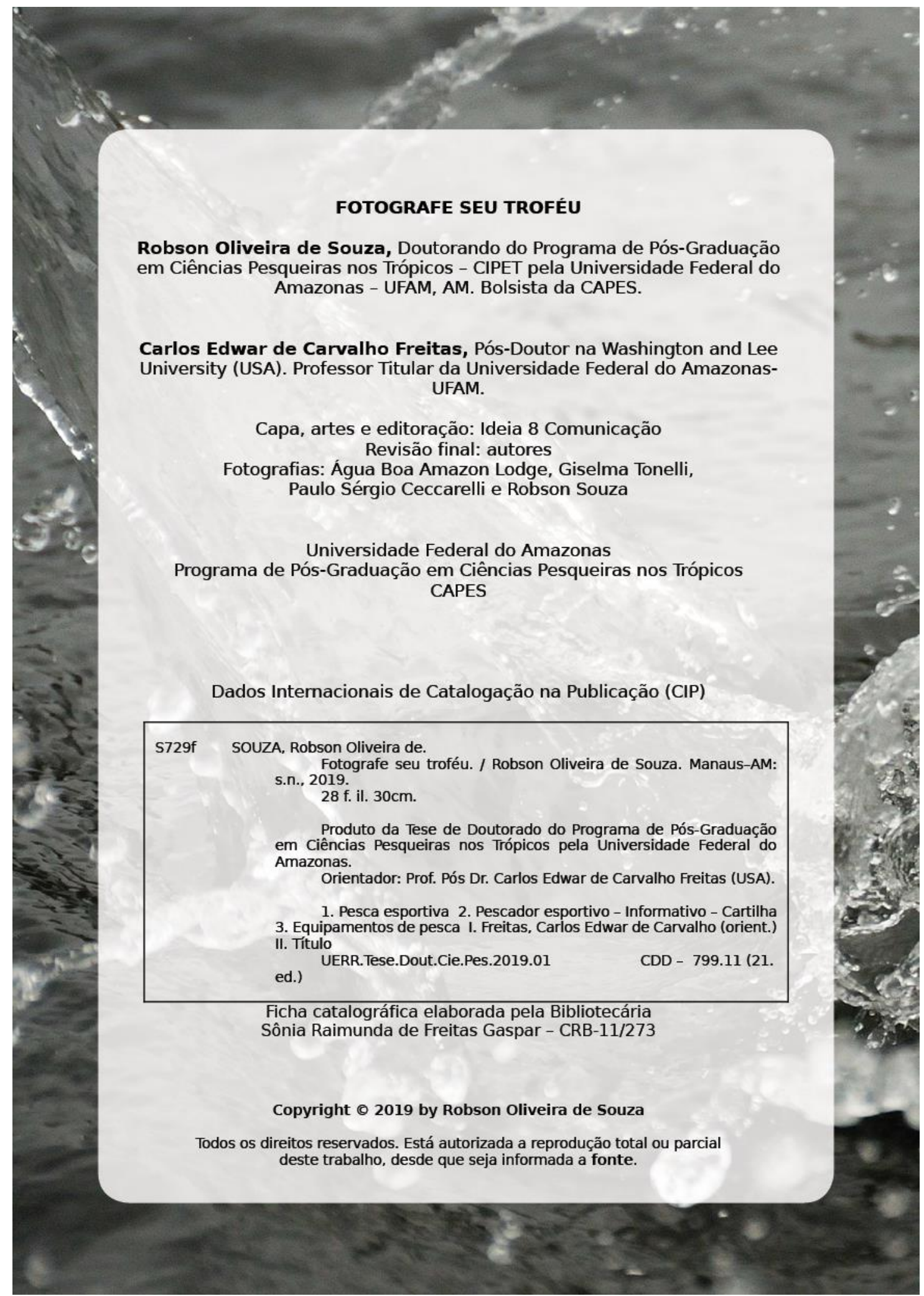




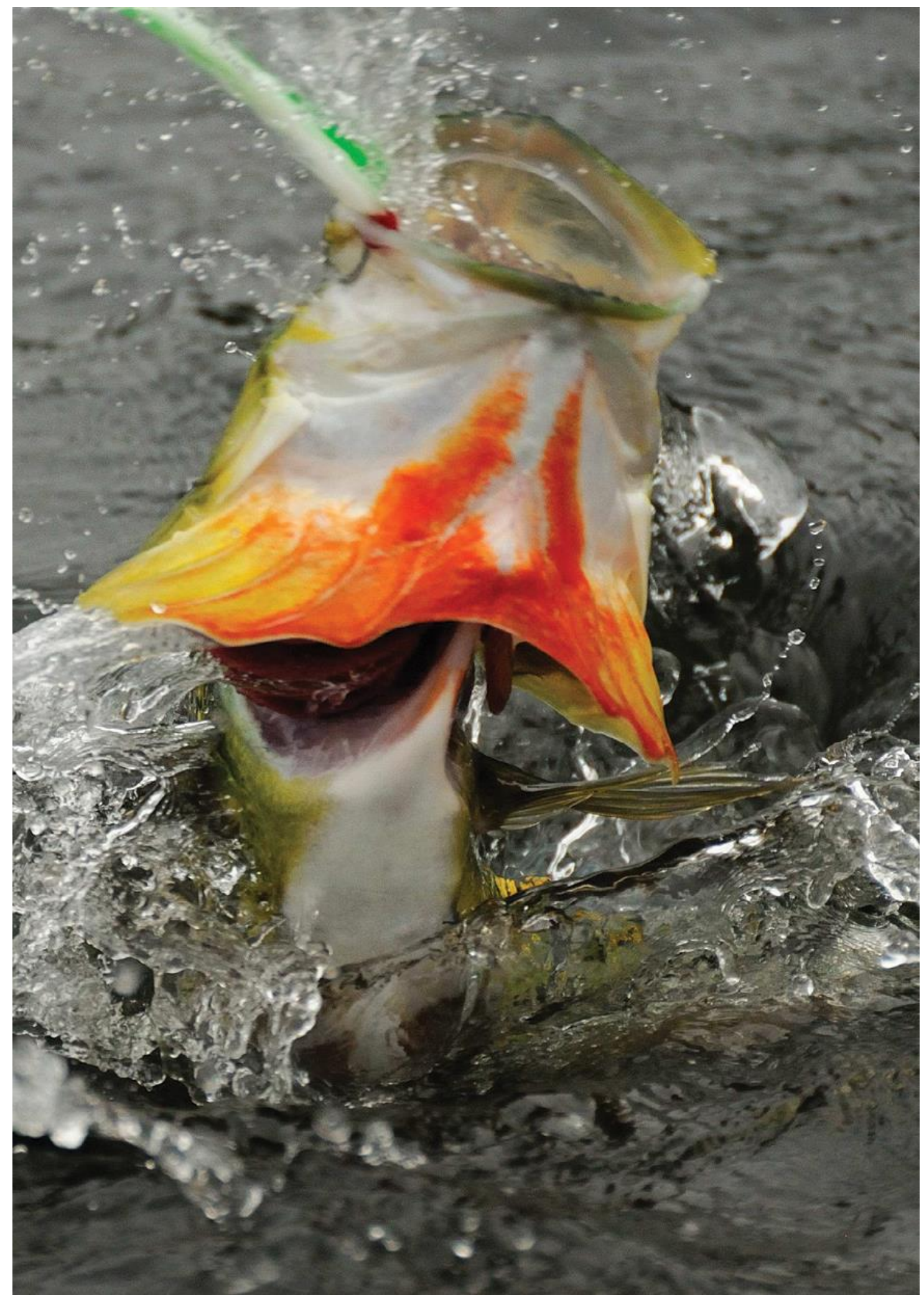




\section{SUMÁRIO}

\section{APRESENTAÇÃO}

INFORMAÇÕES PARA OS PESCADORES ESPORTIVOS QUE

PRATICAM O PESQUE-E-SOLTE

EQUIPAMENTO DE PESCA

Vara

Carretilha ou Molinete

Flyfishing

Linhas

Anzol

Iscas artificiais

Iscas vivas

LOCAL DA FISGADA

BRIGA COM O PEIXE

PÓS-CAPTURA

Passaguá ou Puçá

Alicates de contenção

POSIÇÃO E RETIRADA DO PEIXE DA ÁGUA

MANUSEIO DO PEIXE

Brânquias ou Guelras

Pedúnculo caudal

TEMPO DE EXPOSIÇÃO FORA DA ÁGUA

FOTOGRAFANDO

SOLTURA DO PEIXE

LEMBRETE

REFERÊNCIAS 


\section{APRESENTAÇÃO}

A pesca esportiva como atividade iniciou como uma simples forma de lazer, e de forma favorável vem tendo, em todo o mundo, um crescimento marcante levando a uma modalidade esportiva de ampla difusão. A pesca esportiva como o próprio nome diz, é um esporte que estar tendo um amplo crescimento de adeptos apaixonados pela pesca na modalidade pesque-e-solte no país e especialmente na Amazônia. Dentre os estados amazônicos que a pesca esportiva é bastante praticada, destacam-se o Amazonas, Pará, Roraima, Tocantins que investem fortemente na pesca esportiva. Um exemplo dessa esportividade e da sensação de captura de grandes troféus, ocorreu em novembro de 2010, quando a Internation Game Fish Association - IGFA homologou a captura do maior tucunaré-açu fisgado até hoje em Santa Isabel do Rio Negro, no Amazonas - AM, com 13,19 quilos. Outro exemplo amazônico é captura da piraíba,fisgada no Rio Solimões em 2009, com 155 quilos, considerado o maior indivíduo dessa espécie a ser fisgado na pesca esportiva.

O Brasil possui uma ampla rede hidrográfica com mais de $8 \mathrm{~km}$ de costa e uma variedade de peixes nativos interessante para a pesca esportiva. O Brasil desde de 0 ano de 2009, através da Portaria IBAMA no 4, de 19 de março de 2009, tem adotado o sistema de pesque-e-solte, liberação do peixe após a captura, para que o mesmo tenham uma grande chance de sobrevivência, mantendo a continuidade das espécies, como uma forma de conservação. Esses exemplos de pesque-e-solte utilizados em outros países que praticam a pesca esportiva, como a Europa, o USA e o Japão, foram seguidos no Brasil como forma de conservação dos estoques pesqueiros e preservação ambiental, aliado a uma adequada gestão pesqueira. 
Os Estados Unidos é um exemplo das possibilidades da pesca esportiva como fonte de geração de emprego e renda. De acordo com a National Survey of Fishing, Hunting, and Wildlife - Associated Recreation em 2016, mais de 35,8 milhões de pescadores esportivos licenciados com idade de 16 anos ou mais, isso representa $14 \%$ dos norte-americanos que atuam nessa atividade, gastaram um total de U\$ 46,1 bilhões em atividades ligadas diretamente à pesca esportiva, cuja a demanda de serviços criando e apoiando milhares de empregos diretos e indiretos em todo o país.

A ampla difusão da pesca esportiva nas regiões brasileira, se deve principalmente através de propaganda na mídia como em revistas especializadas, sites, canais de TV especializados em pesca esportiva. Isso tem estimulado cada vez mais brasileiros a ingressarem na atividade de pesca esportiva.

Esta cartilha é um produto da tese de doutoramento do Programa de Pós-Graduação em Ciências
Pesqueiras nos Trópicos da Universidade Federal do Amazonas e tem como propósito informar o pescador esportivo o modo correto de manuseio do peixe (troféu). Não é correto pensar que o peixe é resistente a tudo, e que pode ser pescado de qualquer maneira antes de ser devolvido à água. Para que o sistema de pesque-e-solte funcione e com benefícios é importante o pescador esportivo entender e executar as dicas desta cartilha, de tal forma que o peixe possa se recuperar e continuar e se desenvolver em seu ambiente, garantido a sua sobrevivência.

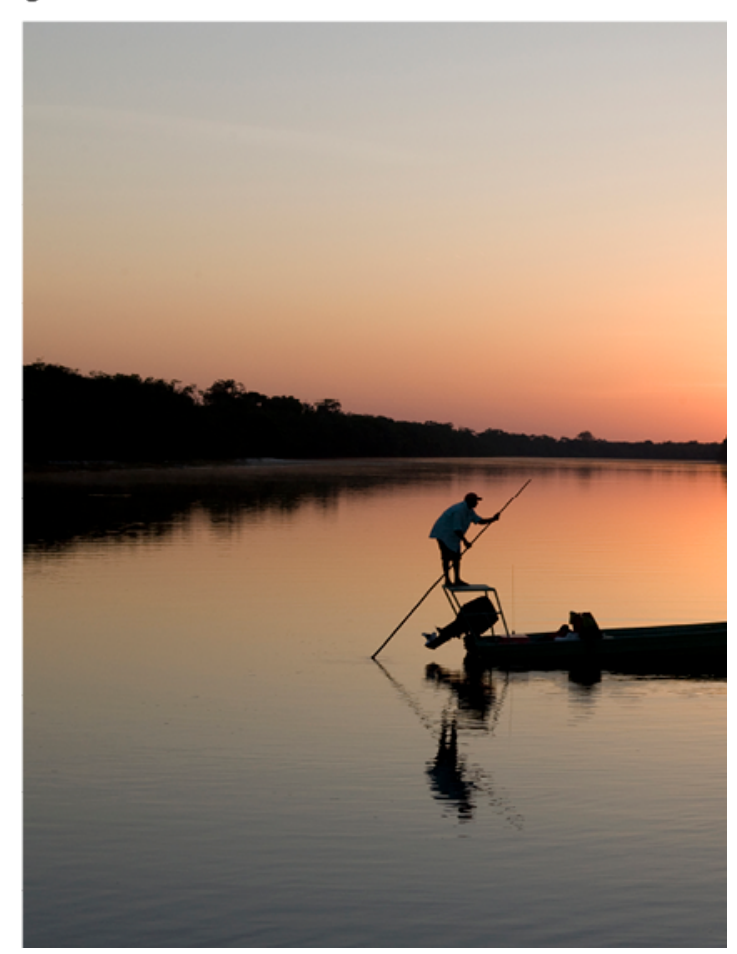


INFORMAÇÕES PARA OS PESCADORES ESPORTIVOS QUE PRATICAM O PESQUEE-SOLTE

Os principais fatores de mortalidade dos peixes capturados e devolvidos à água são o stress, os ferimentos em órgãos fundamentais e o tempo de manuseio do peixe fora da água.

\section{EQUIPAMENTO DE PESCA}

A escolha de um equipamento excessivamente leve não é sinônimo de "esportividade". Entende-se

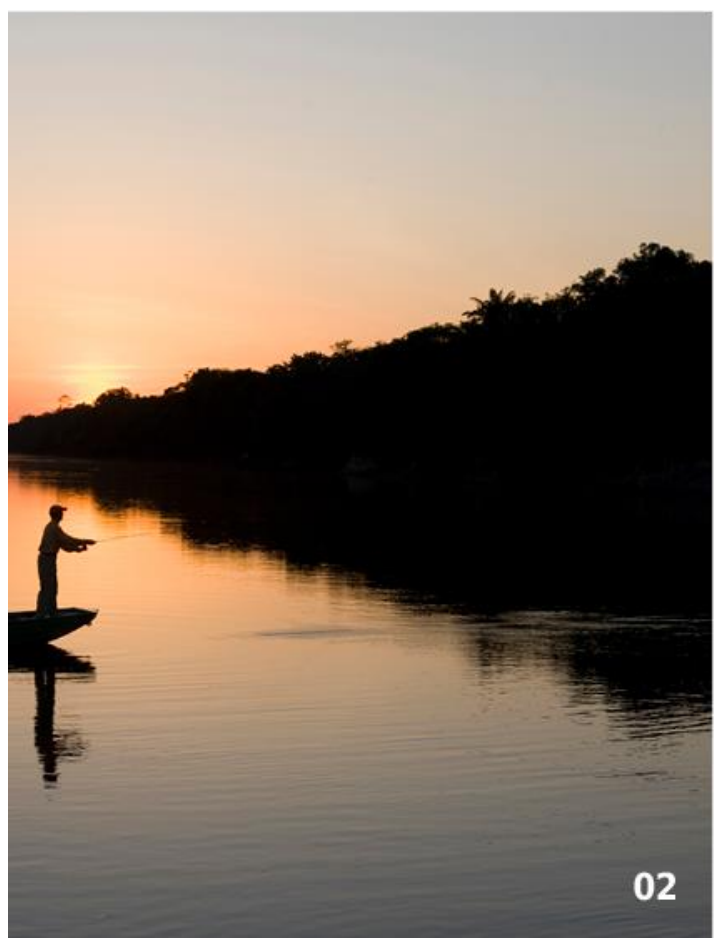

por equipamento leve, o material de pesca composto por vara, carretilha, molinete, flyfishing, linha, chumbada e anzol. 0 equipamento de pesca deve ser compatível com a espécie e o tamanho do peixe que se quer capturar; use sempre uma linha de capacidade um pouco maior que a exigida para cada espécie de peixe. Isso fará com que a luta dure menos tempo e evitará que o peixe fique exausto, aumentando assim as suas chances de sobrevivência.

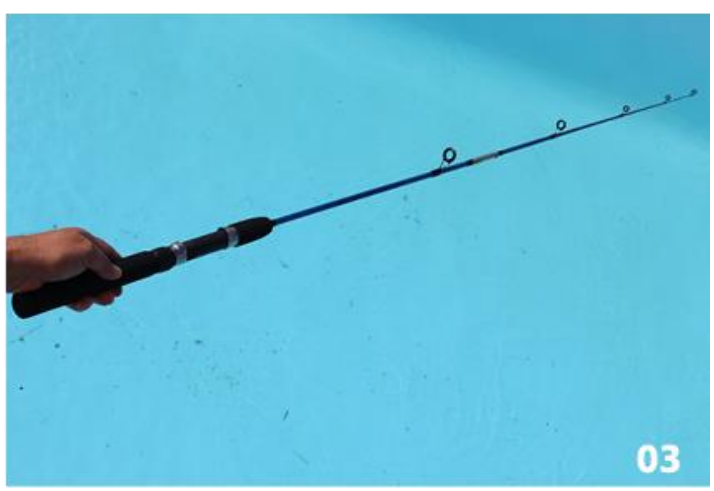

\section{Vara}

Varas com libragem incorreta são a maior causa de se perder um peixe na fisgada ou durante o re-

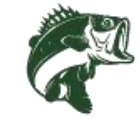


colhimento. Varas muito pesadas fazem o pescador perder peixes de porte menor e varas muito leves não suportam peixes maiores, nesses casos o pescador deve adequar seu material para o tipo de pescaria e assim melhorar a performance e trazer menos prejuízos a saúde do peixe.

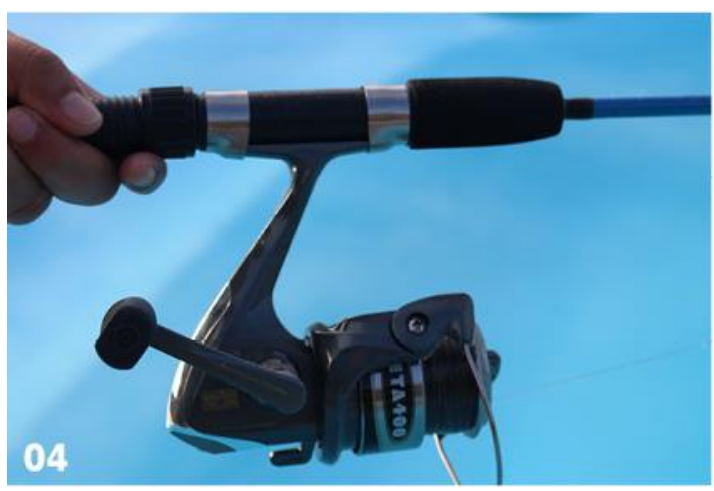

\section{Carretilha ou Molinete}

A carretilha é um equipamento de pesca com função específica que permite ao pescador esportivo tracionar a linha para recolher o peixe quando fisgado. Função que é desempenhada também pelo molinete. A carretilha tem a capacidade de tração maior do que o molinete. Esses equipamentos surgiram da necessidade do pescador esportivo ter mais a linha à sua disposição, para um arremesso mais longo ou para fisgar um peixe maior.

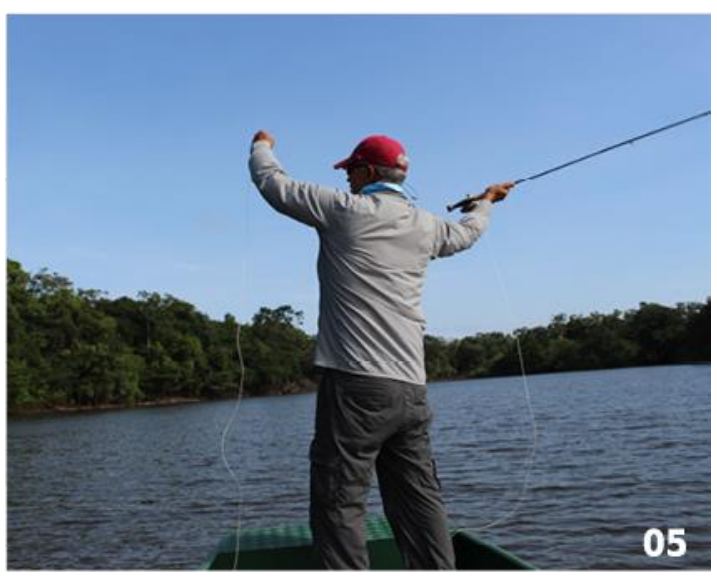

\section{Flyfishing}

É realizada com isca que simula um inseto ou o alimento natural de alguns peixes, utilizando uma vara comprida flexìvel, uma carretilha semelhante a uma bobina comum e uma linha grossa. É uma modalidade de pesca praticada principalmente por turistas estrangeiros.

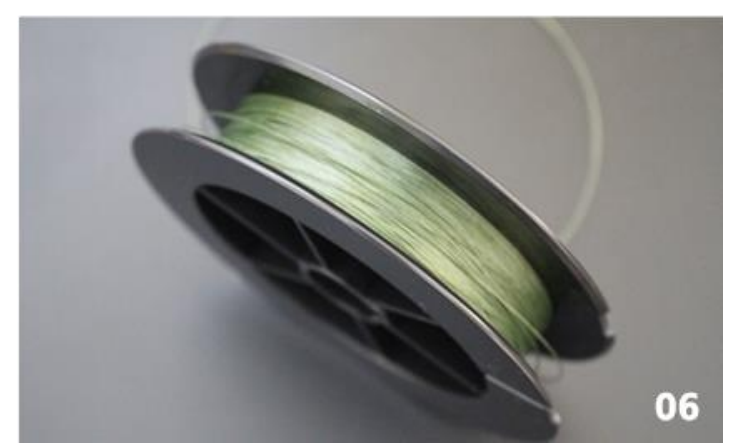




\section{Linhas}

Existem linhas de vários tipos, diâmetros e cores a disposição do pescador esportivo. São fabricadas de nylon em monofilamento ou multifilamento. A espessura e a qualidade da linha são de fundamental importância para o sucesso na captura do peixe. 0 desenvolvimento da técnica do pescador que deverá manter a linha sempre esticada, por vezes dominando o salto de um peixe sem deixar a linha afrouxar, assegura um ganho de esportividade e valoriza o troféu fotografado.

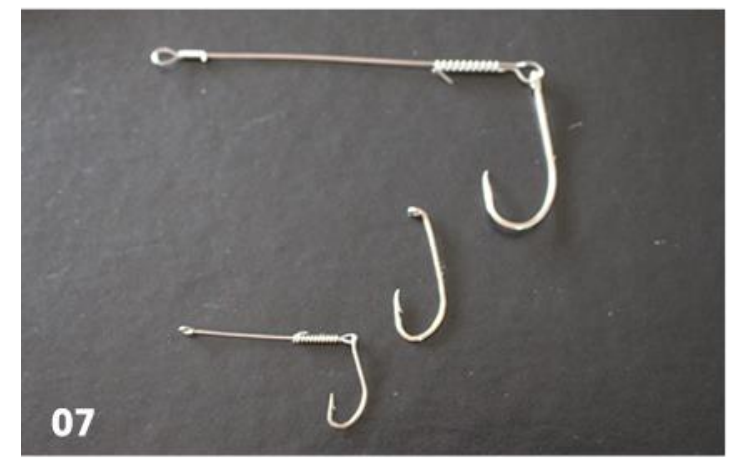

\section{Anzol}

Artefato metálico cuja função é fisgar o peixe. Pesque com anzol e garatéia sem farpa e de preferência confeccionados de materiais não inoxidáveis. Caso o anzol tenha farpa amasse com um alicate, porque facilita na hora de soltar 0 peixe. 0 anzol sem farpa traz alguns benefícios, como a redução no tempo para liberação do peixe e, no caso de um acidente com o pescador, fica muito mais fácil retirar um anzol ou uma garatéia sem farpa. Utilize alicate de contenção para retirar o anzol, prendendo a boca do peixe. Isso evita maiores danos tanto no peixe quanto ao pescador. Retire o anzol com 0 peixe de barriga para cima. Alguns peixes ficam calmos nessa posição.

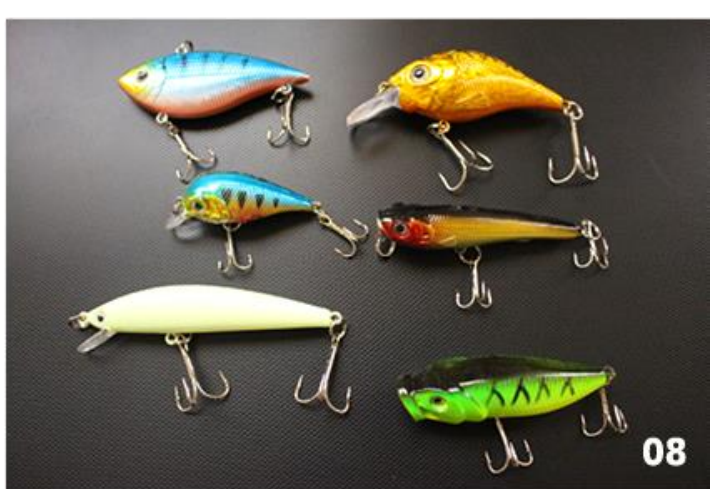

\section{Iscas artificiais}

São indicadas para a captura de peixes predadores. Pesque com iscas artificiais, sempre que pos- 


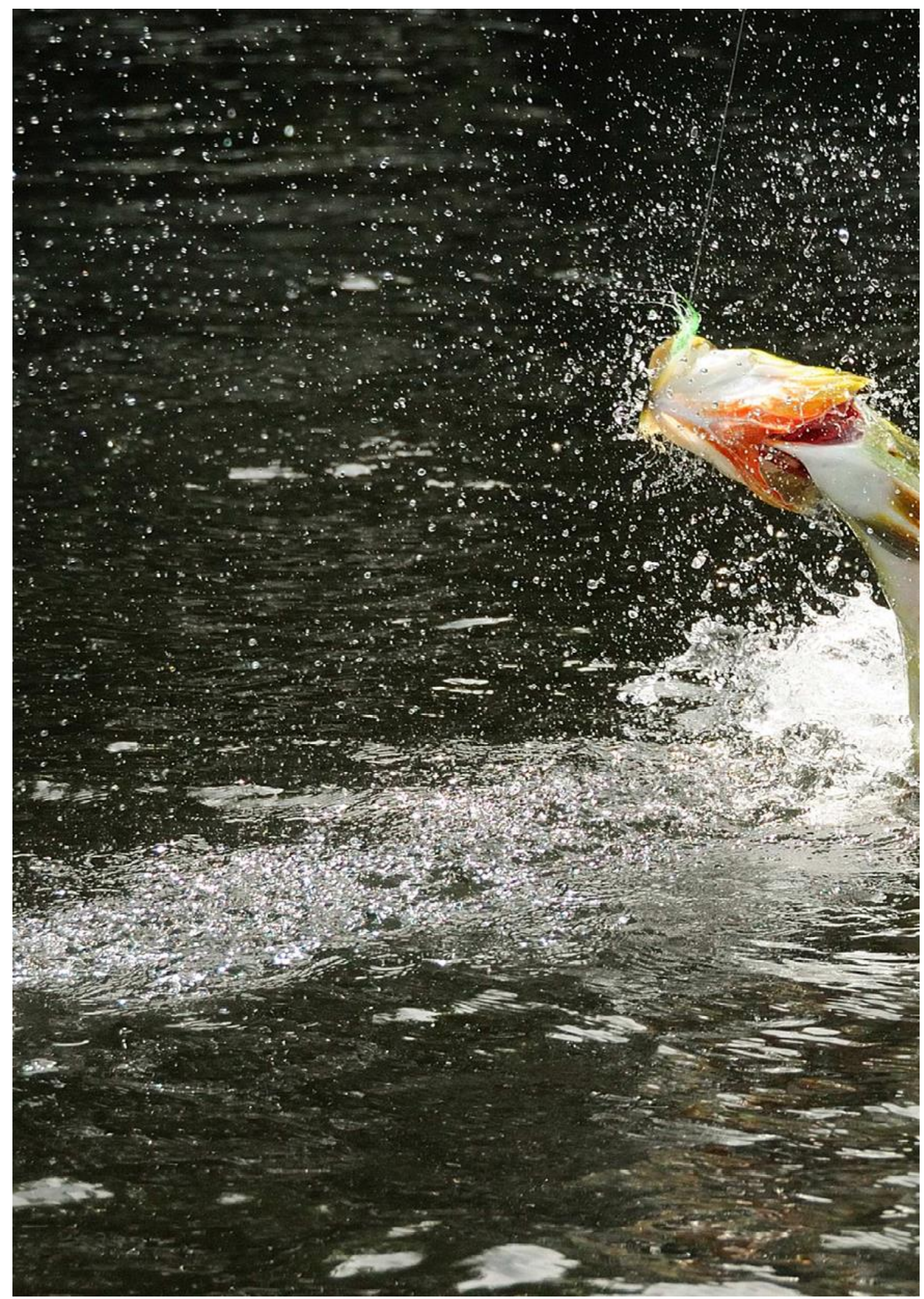




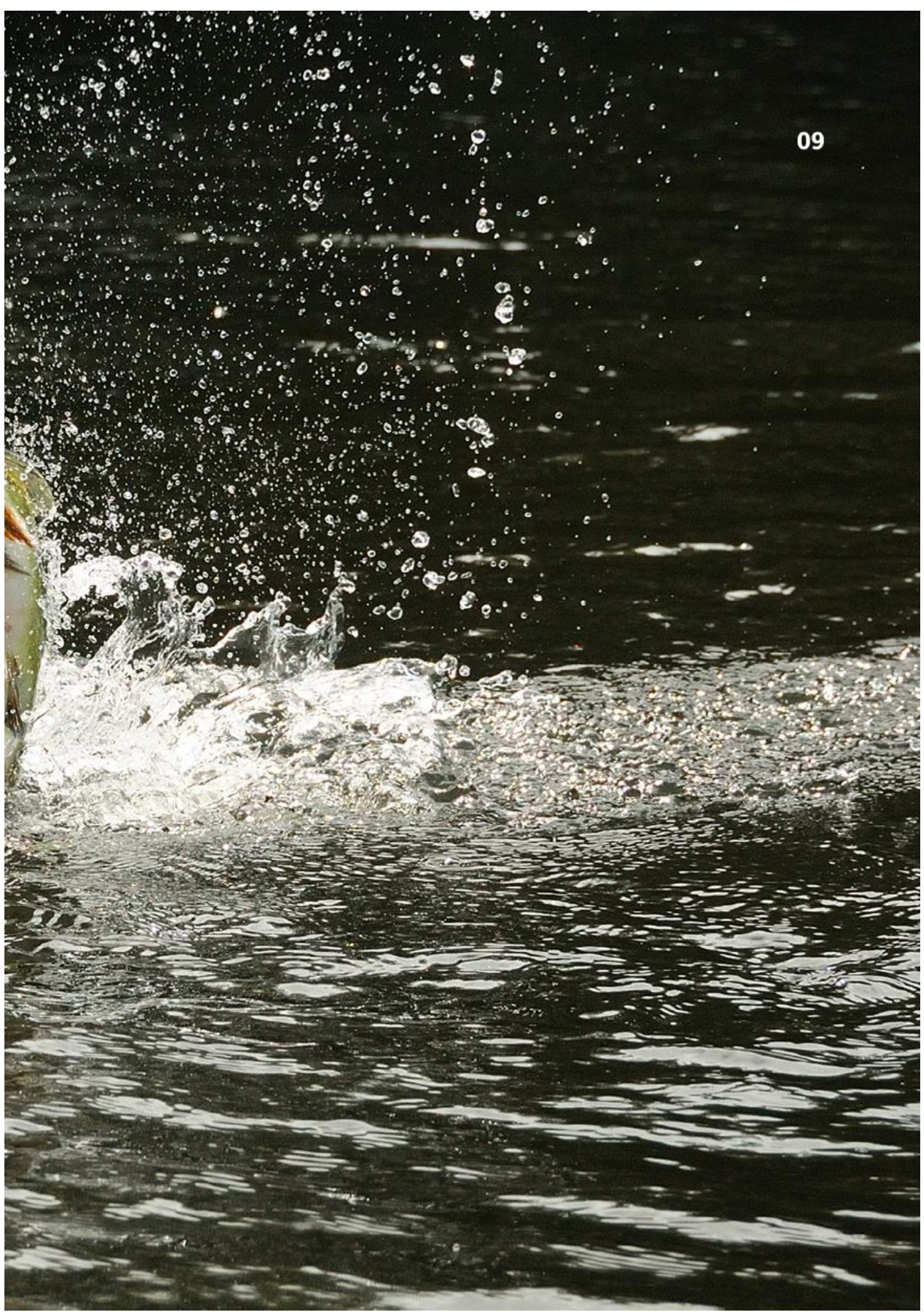


sível, porque são mais difíceis de serem engolidas, evitando ferimentos nos órgãos internos e os ferimentos causados se concentram, na maioria das vezes, na membrana da boca, o que causa lesões superficiais e de rápida cicatrização. As iscas artificiais podem ser do tipo: superfície, de meia água e de fundo.

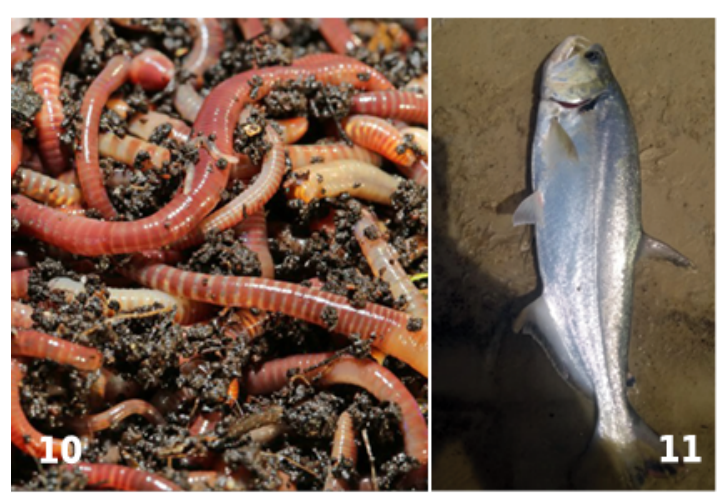

\section{Iscas vivas}

Ao selecionar a isca correta, amplia-se a chance de pescar a espécie de peixe desejado. Entre as espécies de peixes que podem ser capturados com iscas vivas e particularmente com insetos vivos, estão cinco dos mais cobiçados pelos pescadores esportivos, são eles os tucunarés, trutas, traíras, aruanãs e os dourados. Alguns estudos têm indicado que o uso da isca viva aumenta a mortalidade dos peixes capturados após a soltura.

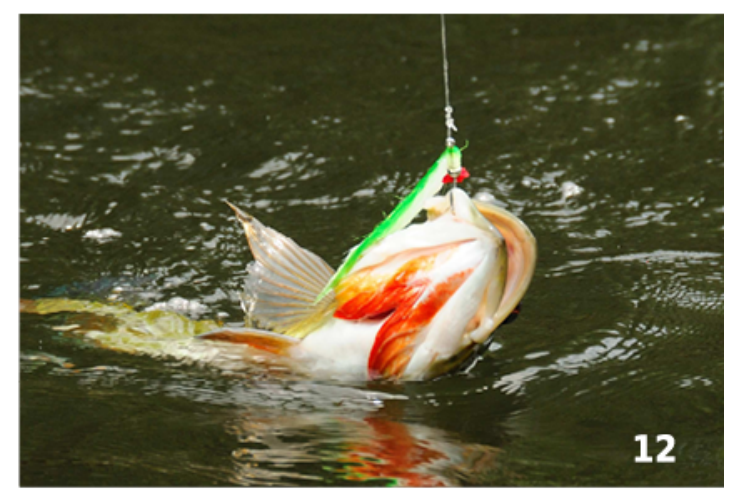

\section{LOCAL DA FISGADA}

0 ideal seria se todos os peixes fossem fisgados pela membrana superior ou membrana inferior, mas nem sempre isso acontece. Quando a pescaria é feita com iscas artificiais pequenas como jigs, ou com iscas vivas, a chance do peixe ser fisgado mais profundamente pela garganta ou pelas guelras é muito alta. Jamais puxe a linha quando $o$ anzol estiver preso na garganta do peixe. Corte a linha o mais perto possível do anzol e rapidamente devolva o peixe à água, isto aumentará a suas chan- 
ces de sobrevivência. Quanto mais tempo o peixe ficar fora da água e quanto mais o pescador esportivo tentar retirar o anzol, menores serão as possibilidades de sobrevivência desse peixe.

\section{BRIGA COM O PEIXE}

Diminua o tempo de briga com o peixe para evitar que ele entre em estado de fadiga. Esta situação poderá comprometer a sua recuperação após a soltura. Na pesca de peixes grandes, evitar o excessivo estresse produzido pelo esforço de tração exercido sobre o peixe durante o tempo de briga (relação peixe e pescador). É necessário que o equipamento seja compatível com o tipo de peixe que se deseja fisgar. 0 equipamento de pesca serve para facilitar a pescaria e não para guinchar ou rebocar o peixe.

\section{PÓS - CAPTURA}

Os peixes ao serem capturados, 0 pescador utilizará outros acessórios que irão ajudar no manuseio do mesmo e trazer menos danos a este peixe antes da sua devo-

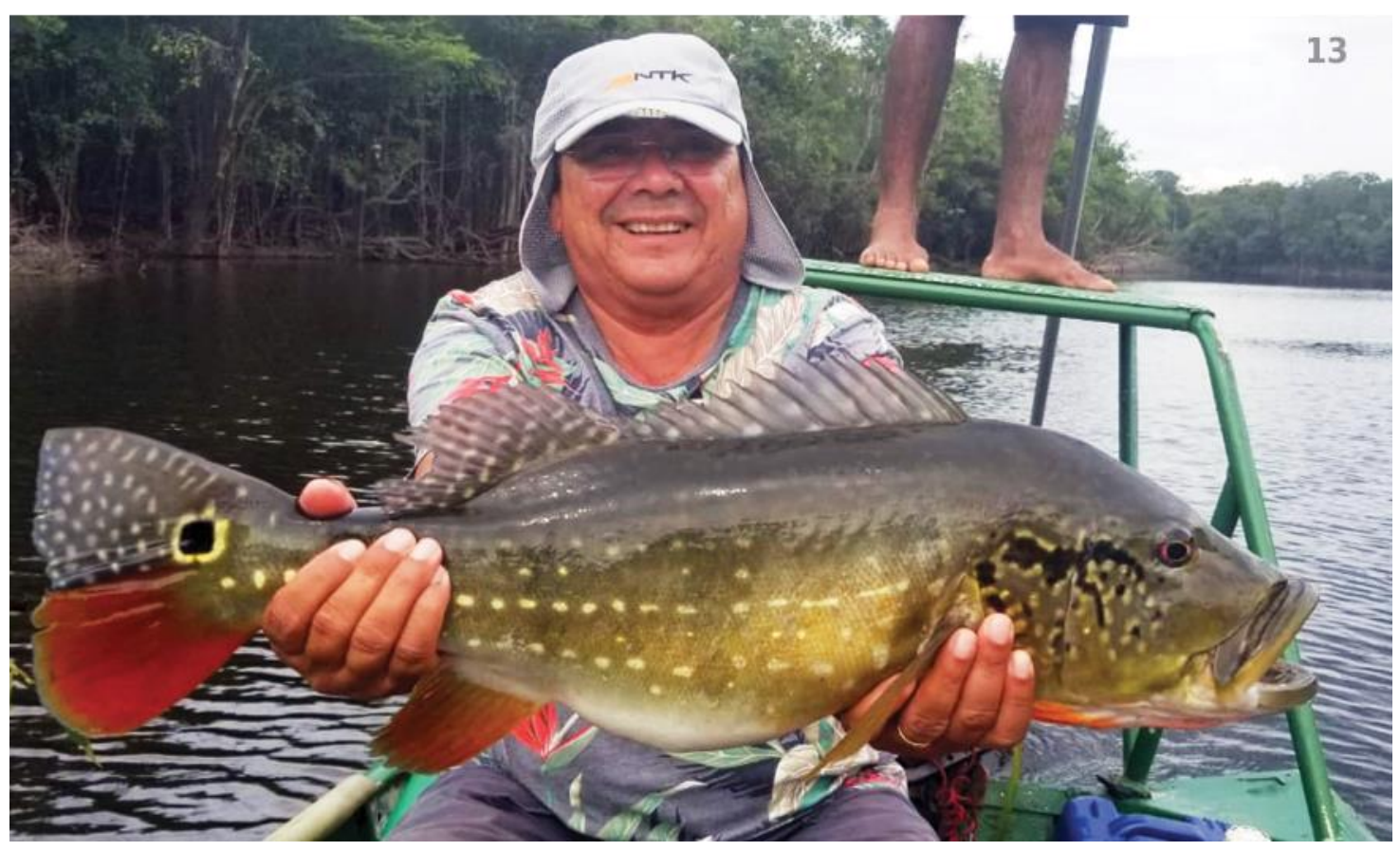


lução para o ambiente aquático. Vale observar que tais acessórios, se utilizados de maneira incorreta, podem provocar danos aos exemplares capturados. Abaixo estão relacionados alguns desses equipamentos que são essenciais e ajudam na hora de sua captura:

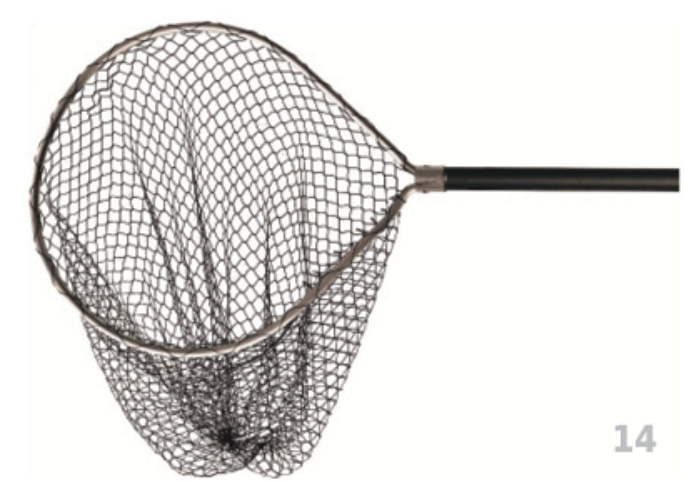

PASSAGUÁ OU PUÇÁ

Passaguá ajuda a retirar o peixe da água, porém, pode provocar a retirada de muco e escamas, se o material for abrasivo, o que poderá ser agravado se a rede for confeccionada com linhas de náiIon. Dê preferência a passaguá com tecido de algodão ou, se for sintético, deverá ser de linha entrelaçada, sem nós, pois esse material é macio e não provoca danos aos peixes capturados. Mesmo sendo um acessório apropriado, o peixe pode perder 0 muco tentando escapar da rede e ficar vulnerável a doenças.

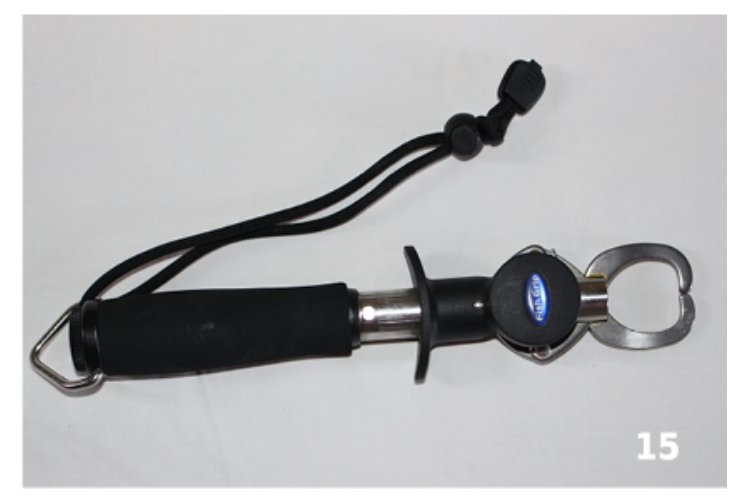

\section{ALICATES DE CONTENÇÃO}

O uso de alicates de contenção ajudam na manipulação da maioria das espécies de peixes esportivos e com dentição óssea afiada, imobilizando o peixe de forma segura e permitindo a retirada do anzol com maior rapidez. Os alicates com garra e associados a pesagem e medição, mas o mal uso desse equipamento também pode prejudicar o peixe. Use-o para a imobilização e contenção do peixe, evite segurar o peixe na vertical por muito tempo 
para não comprimir seus órgãos. Os alicates de bico longo podem acelerar a retirada de um anzol fisgado profundamente. Existem hoje no mercado um acessório chamado saca-anzol, esse equipamento é indicado em casos onde o anzol tenha penetrado fundo no peixe, ou no caso de iscas artificiais, o peixe a tenha engolido. Caso não seja possível retirar o anzol, devido a fisgada ser profunda, corte a causado pela retirada de um anzol.

\section{POSIÇÃO E RETIRADA DO PEIXE DA ÁGUA}

O pescador esportivo deve realizar esse procedimento com 0 peixe ainda na água, retire 0 anzol tão rapidamente quanto possível, usando alicates de contenção do tipo "boga grip", que são uma ótima opção. As vezes
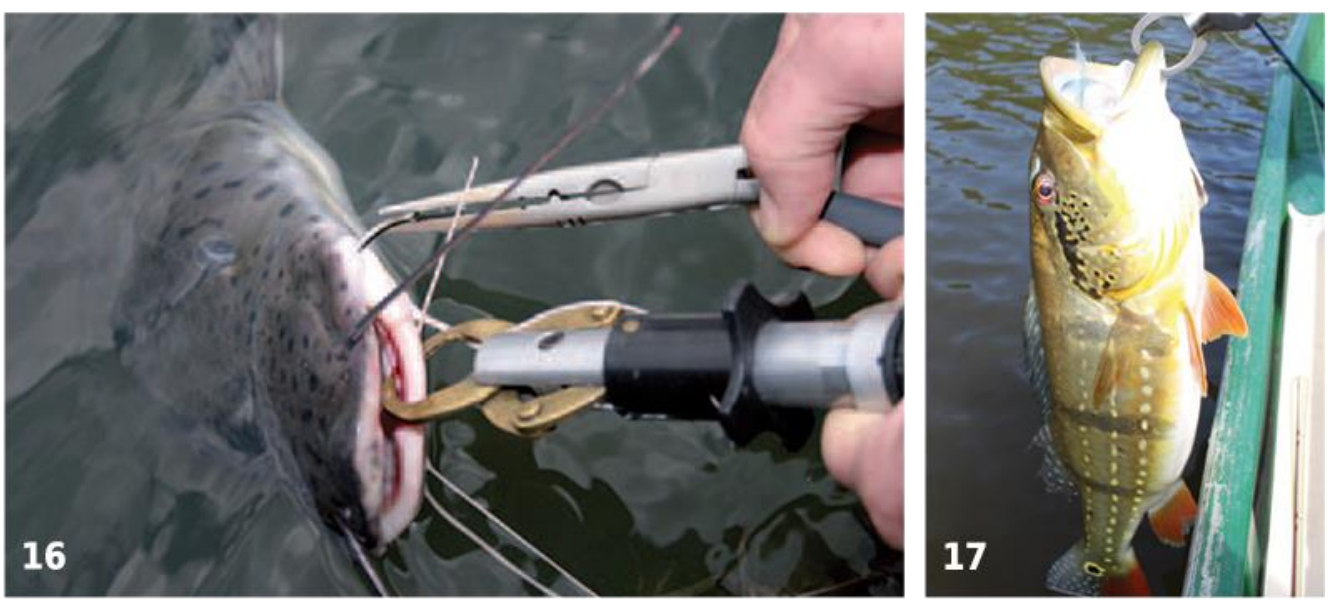

linha e deixe 0 anzol dentro do pei$x e$, que os ácidos estomacais irão dissolver o anzol em pouco tempo. Seja delicado e rápido. Especialmente os peixes pequenos podem morrer em decorrência do choque este procedimento não é possível, porém quanto menos tempo levar é melhor para a sobrevivência do peixe. Deve-se evitar deixar o peixe na posição vertical não somente na hora de retirá- 


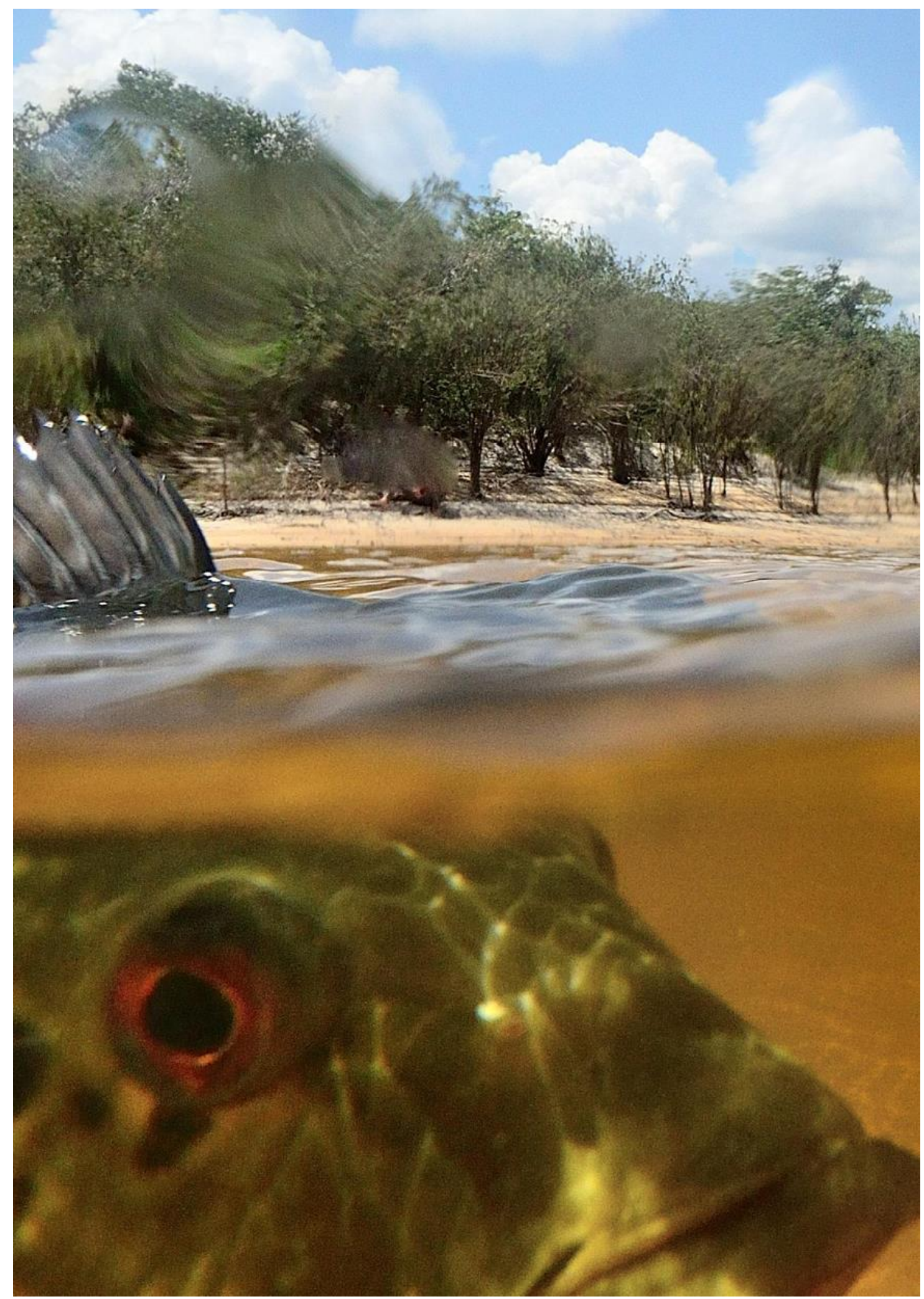




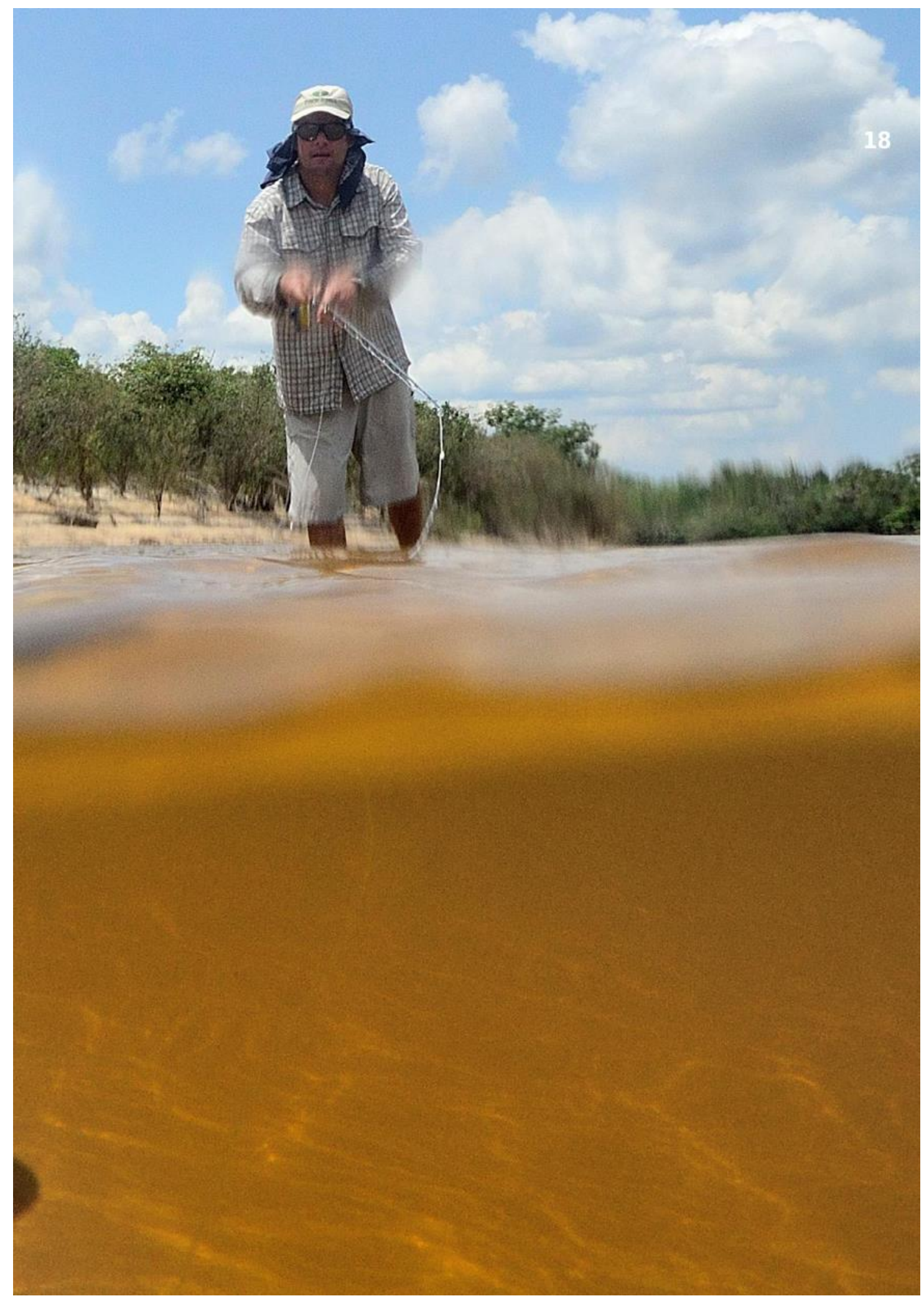


-lo da água quanto no momento da fotografia. Caso o peixe seja grande, o procedimento deverá ser feito pelo pescador esportivo dentro da água em locais mais rasos, inclusive para fazer a fo- segurar um peixe é aquele que menos o estressa, mantê-lo sempre na posição horizontal, para evitar quaisquer danos físicos ao animal.

\section{BRÂNQUIAS OU GUELRAS}

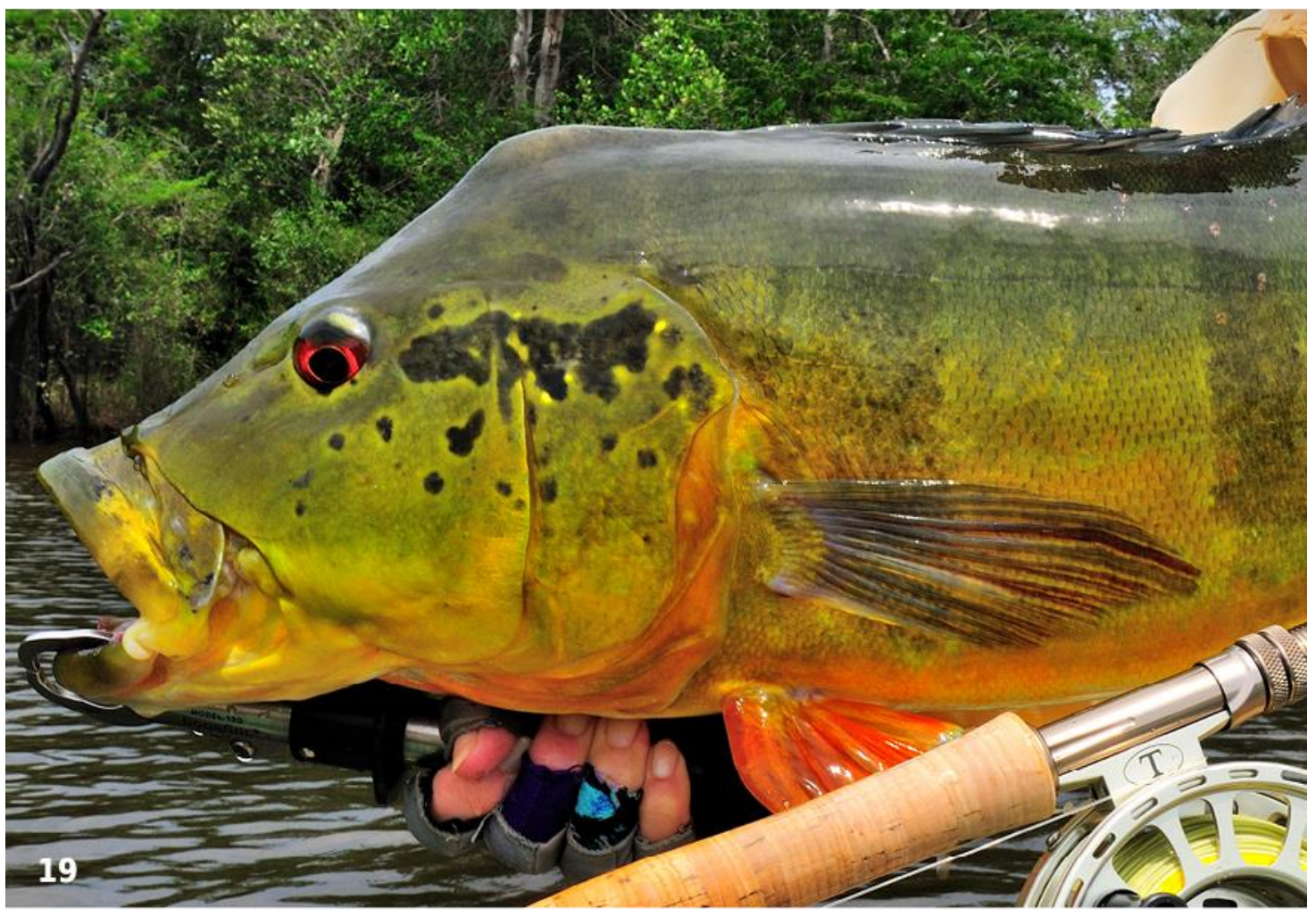

tografia.

MASUEIO DO PEIXE

$\mathrm{O}$ procedimento adequado de se
Ao manusear um peixe, a delicadeza é fundamental. Evite tocar com os dedos ou as unhas nas guelras, são os órgãos responsáveis pela 
respiração dos peixes. Esta região é muito delicada, o contato das mãos pode causar lesões e levar a contaminação por fungos e bactérias, resultando em diminuição da eficiência respiratória e doenças. Ten-

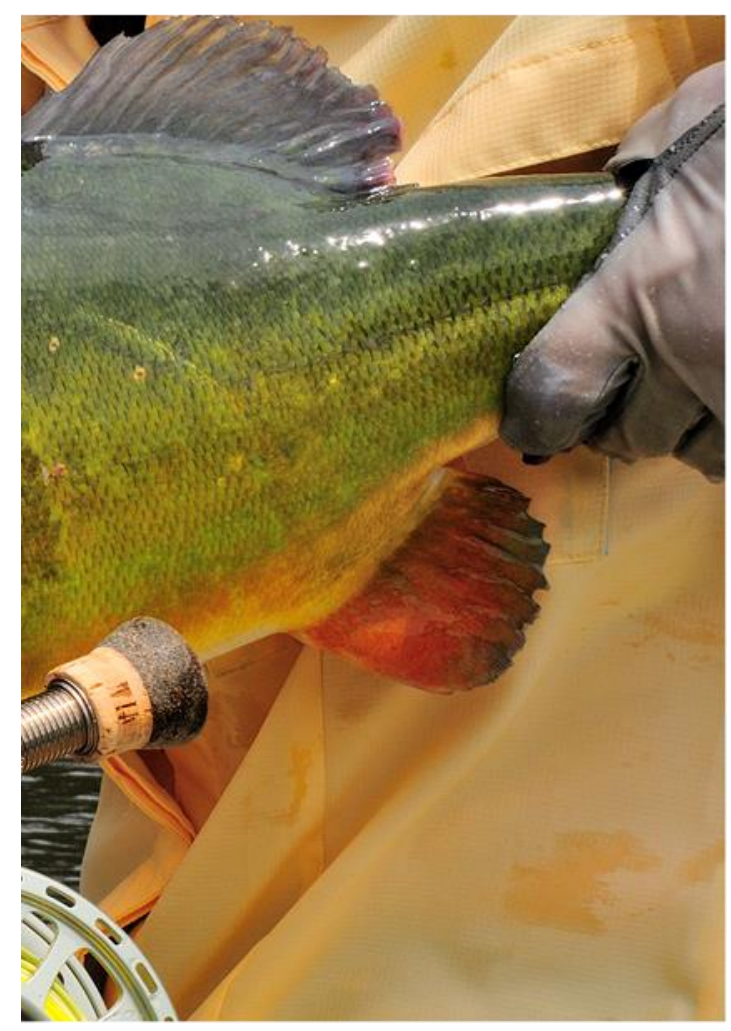

te sempre, segurar ou manusear o peixe com as mãos molhadas e na horizontal. Segure o peixe de modo correto para que ele se contorça ao mínimo, movimente com cuidado, pois pode ocorrer deslocamentos e traumatismo nos órgãos internos e na estrutura óssea.

\section{PEDÚNCULO CAUDAL}

É o local em que a maioria dos pescadores segura os peixes, geralmente colocando-os de cabeça para baixo. Evite pressionar com muita força a região da cauda para que não ocorra traumatismo ou doenças.

\section{TEMPO DE EXPOSIÇÃO FORA DA ÁGUA}

Os pescadores esportivos que desejam fazer registro fotográfico do peixe (troféu), devem retirar o peixe da água e realizar este procedimento o "mais rápido possível", evitando a retirada do muco, elemento que traz proteção ao peixe no ambiente aquático. 0 tempo é essencial, um peixe fora da água por muito tempo, sofrerá danos cerebrais em função da falta de oxigênio. Até mesmo um peixe pego 
ou manuseado gentilmente pode ficar muito exausto para se recuperar caso fique por um período muito prolongado fora da água. É importante o pescador esportivo lembrar que o peixe lutou bravamente até ser recolhido, sendo assim, o ideal seria oxigená-lo antes de o retirar da água para fazer a foto.

\section{FOTOGRAFANDO}

Ao fotografar seu troféu, o ideal seria com o peixe na água ou se o peixe for retirado da água, procure colocá-lo em lugar liso e molhado para medir, pesar e tirar foto. Se for segurar o peixe para a foto, procure mantê-lo sempre na horizontal, evitando danos físicos no mesmo, não abrace o peixe para fazer uma foto, mesmo que sua roupa seja de material leve e de secagem rápida, ela irá retirar o muco fazendo com que 0 peixe fique vulnerável a doenças. Molhe as mãos quando for segurar o peixe. Mãos secas, panos ou papel tiram o muco, que serve de proteção contra infecções e diminuindo as chances de sobrevivências. Pescador esportivo lembre-se que estas operações devem ser realizadas no menor tempo possível.

\section{SOLTURA DO PEIXE}

Solte o peixe em águas calmas, sem correntezas, evitando que ele se esforce sem necessidade. Solte o peixe com cuidado e segure-o pela cauda, esperando

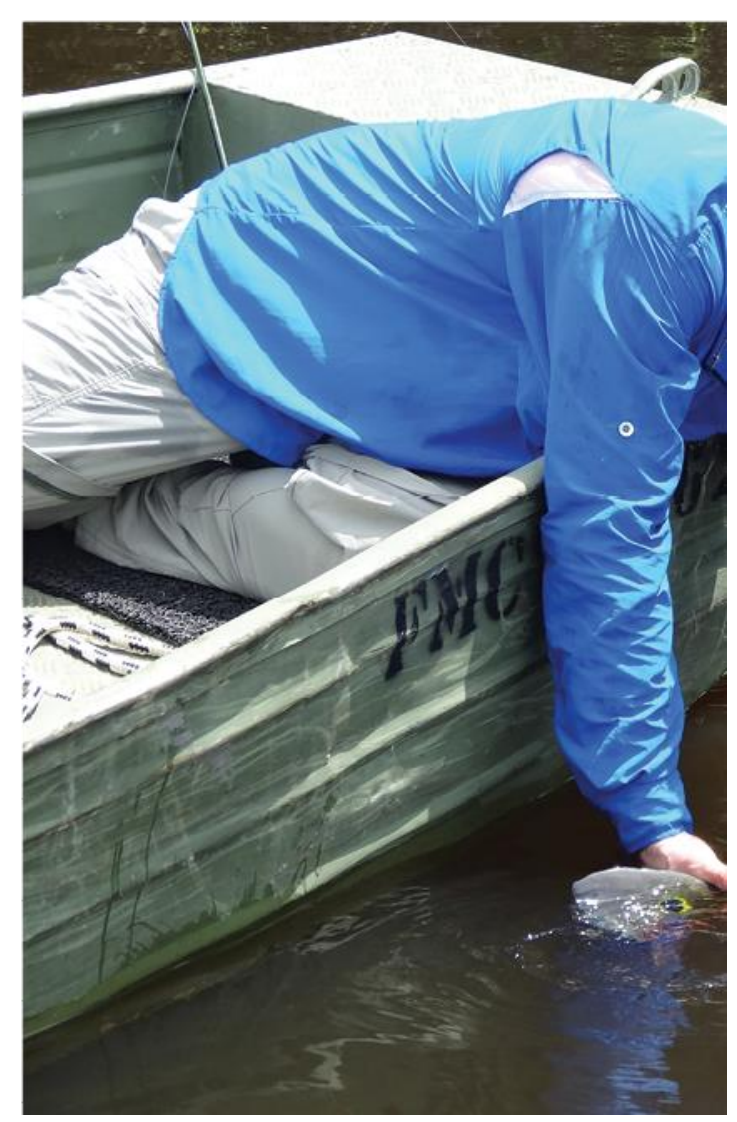


que se recupere, até que con- vimento de "vai e vem" com o siga nadar normalmente. Evi- peixe quando colocá-lo na água. te segurá-lo pela boca ou pelos Esse movimento incorreto pode opérculos, para que ele possa modificar a forma de entrada narespirar. Um procedimento mui- tural de água, podendo ocasionar to importante é colocar o peixe o comprometimento das guelras. sempre no sentido da boca vol- Em rios que existem muitas piratada contra a correnteza para que a água entre pela sua boca passe pelas guelras e saia pelo opérculo. Nunca colocá-lo favor da correnteza e não faça o monhas o recomendado é soltá-los em águas mais rasas para que 0 mesmo tenha tempo de se recuperar totalmente e não se tornar uma presa fácil.
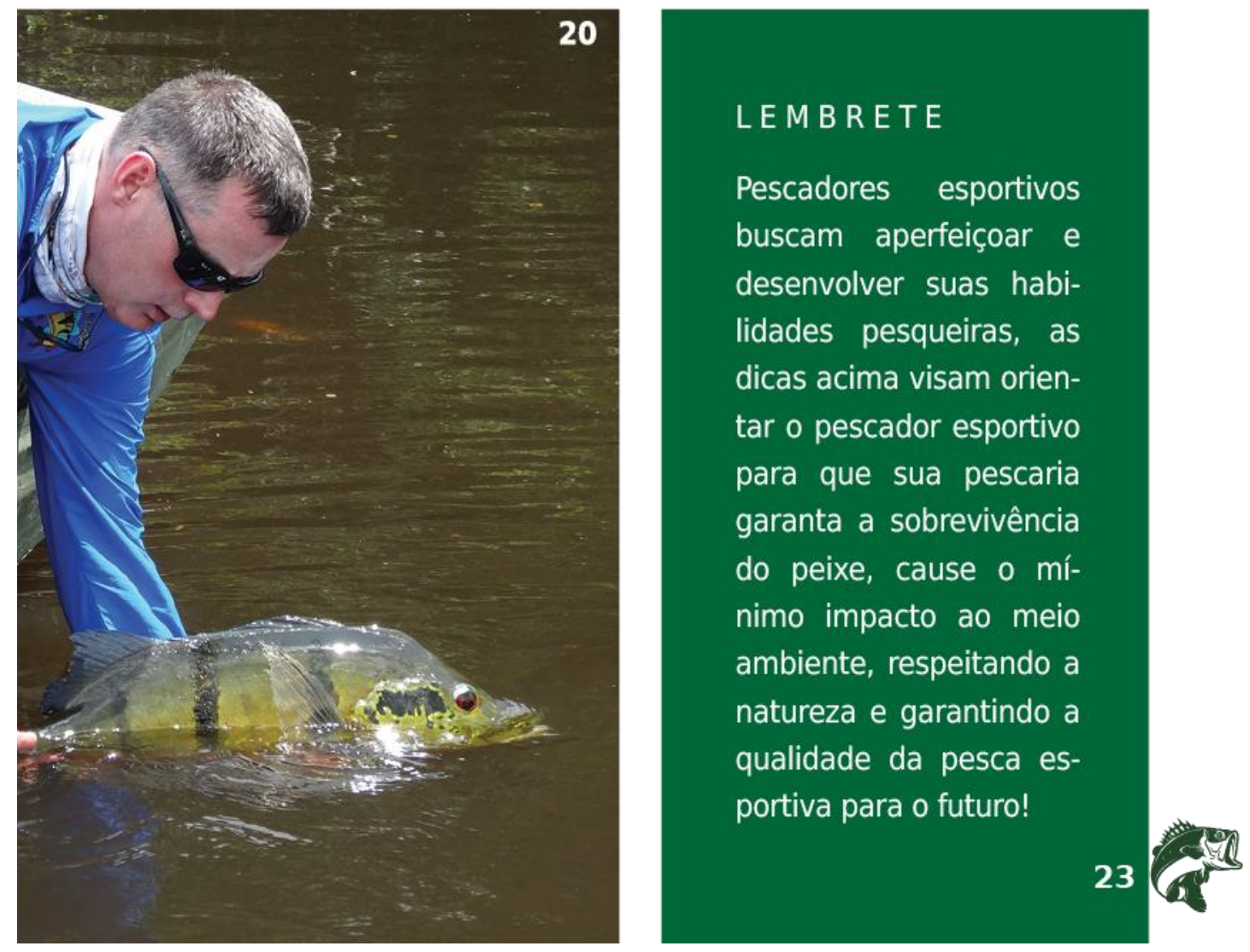


\section{Referências}

BRASIL. Ministério do Meio Ambiente. Instituto Brasileiro do Meio Ambiente e dos Recursos Naturais Renováveis. Programa Nacional de Desenvolvimento da Pesca Amadora. Caderneta de Pesca. Brasília, 2010. 70p.

Ceccarelli, Paulo Sérgio. Pesque-e-solte: informações gerais e procedimentos práticos / Paulo Sérgio Ceccarelli, ...[et al]. - Brasília: Ibama, 2006. 42p.: il. color.; cm.

CHAVES, Paulo de Tarso; FREIRE, Kátia Meirelles Felizola. A pesca esportiva e o pesque-e-solte: pesquisas recentes e recomendações para estudos no Brasil. Bioikos, Campinas, 26(1):29-34, jan./jun., 2012.

LIMA, Ricardo Pinheiro; MARQUES, Débora Karla Silvestre; SILVA, Roberto Aguilar Machado Santos. Procedimentos corretos para a prática do Pesque-e-Solte. Corumbá, MS: Embrapa Pantanal, 2007. 3p. ADM - Artigo de Divulgação na Mídia, n. 111. Disponível em: http://www. cpap.embrapa.br/publicacoes/ online/ADM110. Acesso em:18 junh.2018.

PAPA, Giovani. Como manusear os peixes de forma correta. 2017. Disponível em:< https://www.giovanipapa.com/single-post/2016/07/12/ Dicas-de-Como-Manusear-os-Peixes-de-Forma-Correta>. Acesso em: 09 Jul 2018.

Portal São Francisco. Pesca. 2018. Disponível em: < https://www.portalsaofrancisco.com.br/esportes/pesca>. Acesso em: 09 jul. 2018.

SANTANA, Wellerson. Portal Pesca Amadora. Pesque e Solte - Dicas e procedimentos. 2013. Disponível em: < http://www.pescamadora.com.br/pesque-e-solte/>. Acesso em: 09 jul. 2018.

Secretaria do Desenvolvimento da Agricultura e Pecuária. Governo do Tocantins. to.gov.br. Orientações para a prática da pesca esportiva no Tocantins. [entre 1997 e 2016]. 12p. 
TERRA DA GENTE. Ranking Mundial de pesca esportiva conta com conquistas em águas brasileiras. 2018. Disponível em: < https://g1.globo.com/sp/campinas-regiao/terra-da-gente/noticia/ ranking-mundial-de-pesca-esportiva-conta-com-recordes-conquistados-em-aguas-brasileiras. ghtml>. Acesso em: 21 junh. 2018.

U.S. Fish and Wildlife Service and Census Bureau. 2016 National Survey of Fishing, Hunting, and Wildlife - Associated Recreation. U.S. FHW/16. April 2018. 144p.

\section{FOTOS}

$1,2,5,9,13,18,19,20$ e fotos da capa:

Água Boa Amazon Lodge, 2019

3 e 4:

Giselma Tonelli, 2019

$6,7,8,10,11,12,1314,15,17$ e 21:

Robson Souza, 2019

16:

Paulo Sérgio Ceccarelli, 2006 


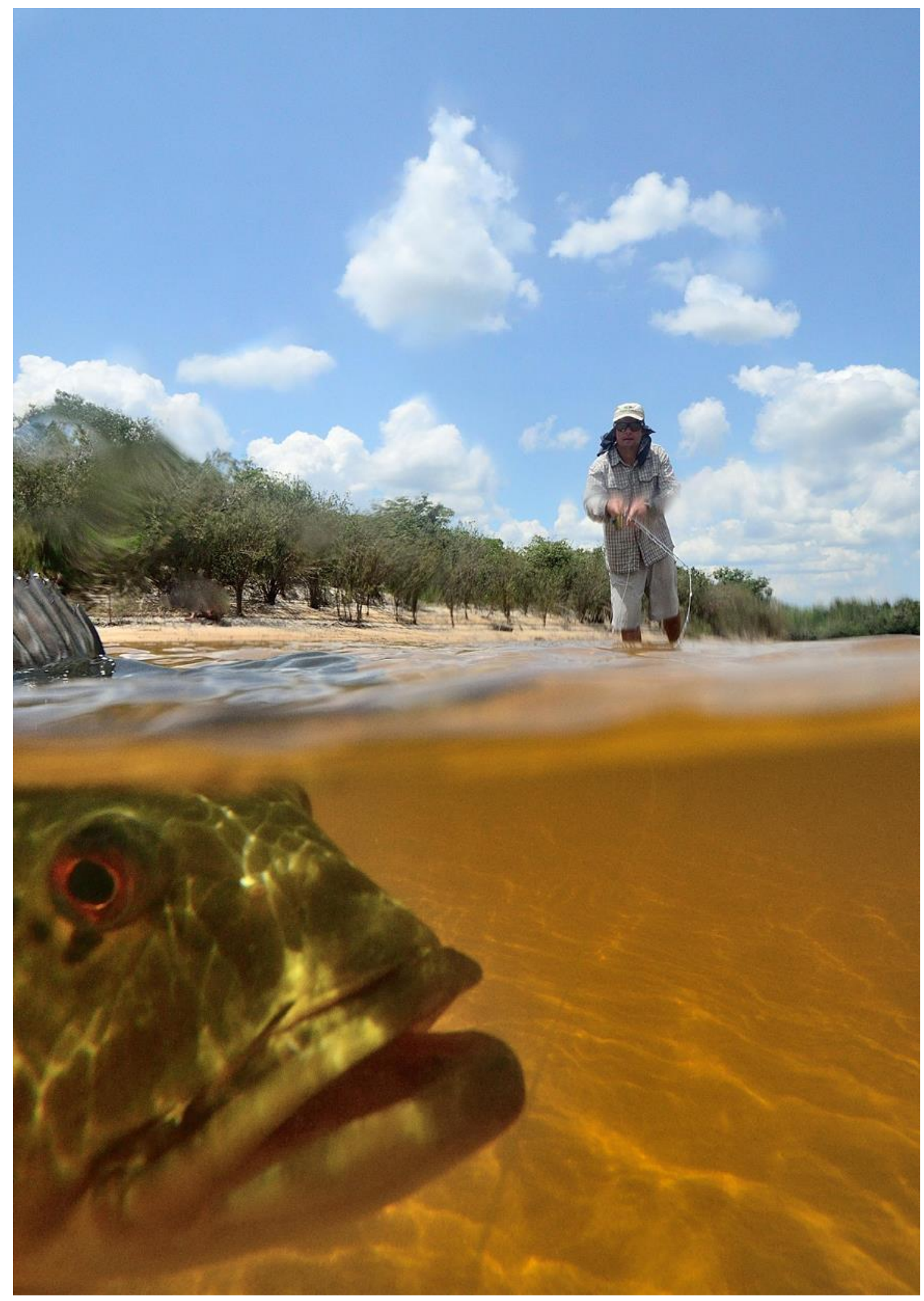




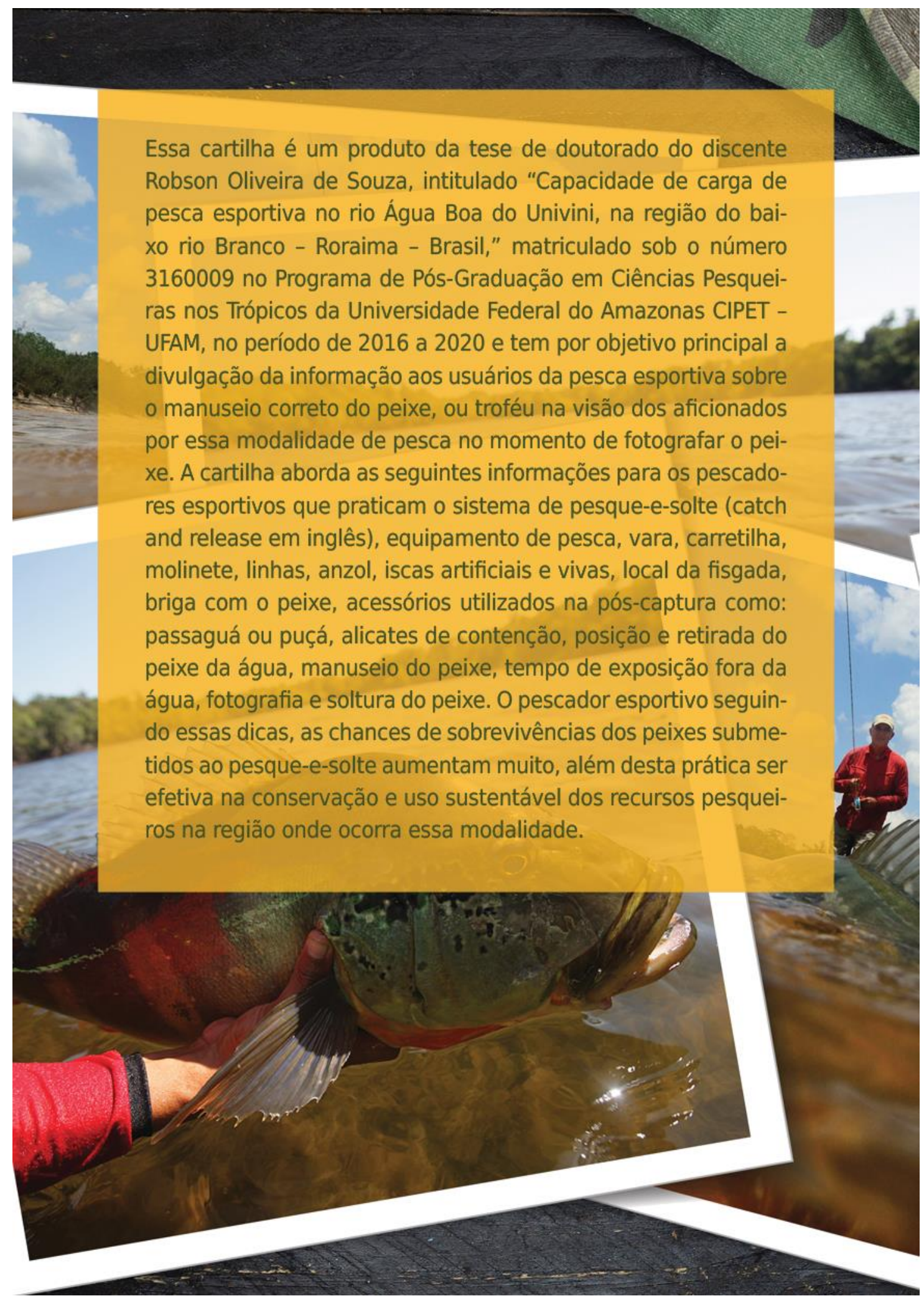

